UNIVERSIDADE DE SÃO PAULO

FACULDADE DE ECONOMIA, ADMINISTRAÇÃO E CONTABILIDADE DEPARTAMENTO DE ADMINISTRAÇÃO PROGRAMA DE PÓS-GRADUAÇÃO EM ADMINISTRAÇÃO

ESTRATÉGIA EMPRESARIAL, GOVERNANÇA E RENDA EM CADEIAS GLOBAIS DE VALOR: CASOS EM TECNOLOGIA DA INFORMAÇÃO

Eduardo Armando

Orientador: Prof. Dr. Adalberto A. Fischmann 
Profa. Dra. Suely Villela

Reitora da Universidade de São Paulo

Prof. Dr. Carlos Roberto Azzoni

Diretor da Faculdade de Economia, Administração e Contabilidade

Prof. Dr. Isak Kruglianskas

Chefe do Departamento de Administração

Prof. Dr. Lindolfo Galvão de Albuquerque

Coordenador do Programa de Pós-Graduação em Administração 


\section{ESTRATÉGIA EMPRESARIAL, GOVERNANÇA E RENDA EM CADEIAS GLOBAIS DE VALOR: CASOS EM TECNOLOGIA DA INFORMAÇÃO}

Tese apresentada ao Departamento de

Administração da Faculdade de Economia, Administração e Contabilidade da Universidade de São Paulo, como requisito parcial para obtenção do título de Doutor em Administração.

Orientador: Prof. Dr. Adalberto A. Fischmann

\section{São Paulo}


Espaço para registro do trabalho

FICHA CATALOGRÁFICA

Elaborada pela Seção de Processamento Técnico do SBD/FEA/USP

Armando, Eduardo

Estratégia empresarial, governança e renda em cadeias globais de valor : casos em tecnologia da informação / Eduardo Armando.

-- São Paulo, 2008. 285 p.

Tese (Doutorado) - Universidade de São Paulo, 2008 Bibliografia

1. Administração estratégica 2. Estratégia empresarial 3. Internacionalização de empresas 4. Competição 5. Cadeia de suprimentos I. Universidade de São Paulo. Faculdade de Economia, Administração e Contabilidade. II. Título.

CDD - 658.4012 
A minha esposa Camila e filhos queridos, Laura e Luis Eduardo, pelo apoio incondicional recebido 


\section{AGRADECIMENTOS}

Não imaginava que ao terminar minha tese de Doutorado em Administração estivesse em débito com tantas partes. Espero ter lembrado de todos. Primeiro, claro, minha esposa e filhos, que acompanharam ansiosos a evolução do trabalho e aceitaram minhas ausências sem reclamações. Este apoio foi fundamental para chegar até aqui. Contudo, houve outros. Preciso citar minha irmã, irmão, mãe e sogros, com quem continuo e continuarei em débito pelo apoio e estímulo. No âmbito da pesquisa, meu orientador, Prof. Dr. Adalberto A. Fischmann, que além da incentivadora e constante presença e apoio, me deixou livre para estudar o que desejasse. Algumas vezes cheguei a achar que ele confiava mais em mim do que eu próprio! O apoio da Tokyo Foundation, bem como de sua equipe no Brasil, localizada na FEA / USP, foi de fundamental importância para que fossem viabilizadas as duas temporadas no exterior: no Institute of Development Studies (IDS) da University of Sussex, Inglaterra sob a orientação do Prof. John Humphrey e no Center on Globalization, Governance, and Competitiveness, na Duke University, EUA sob os auspícios Prof. Gary Gereffi. Aos caros John e Gary e respectivas famílias, bem como às equipes das duas instituições deixo aqui o meu muito obrigado. As duas temporadas foram fundamentais para o aprofundamento e elevação do nível do trabalho. Não posso deixar de lembrar da Profa. Dra. Marly M. Carvalho do Departamento de Produção da Escola Politécnica da USP, que ao participar da banca examinadora da minha dissertação de Mestrado, indicou a obra do Prof. Gereffi. As lúcidas sugestões dos membros da banca do Exame de Qualificação, Profa. Dra. M. Sylvia M. Saes e Prof. Dr. Celso C. H. Grisi, foram de fundamental relevância, Agradeço meus empregadores, Fundação Instituto de Administração (FIA), na pessoa dos coordenadores do MBA Gestão Empresarial, Professores Doutores Almir F. de Sousa e Adelino De Bortoli, e Faculdade Taboão da Serra (FTS). Tenho trabalhado nos cursos de Administração destas instituições nos últimos seis anos e quero destacar a generosa cooperação, não só para a realização das duas viagens, mas também para todo o processo do Doutorado. Também a toda equipe da FEA USP, sempre pronta para atender as minhas solicitações, especialmente na seção de PósGraduação, na Comissão de Cooperação Internacional da FEA / USP (CCINT), na secretaria do Departamento de Administração e na biblioteca. Finalmente e, mais importante, este trabalho jamais teria sido realizado se não fosse o apoio dos empresários e executivos, que concordaram em abrir suas empresas sem pedir nada em troca e que me atenderam toda as vezes que os procurei de forma interessada. Foi estimulante conhecer suas empresas e espero poder retribuir a colaboração. Cabe enfatizar que embora tenha recebido todos estes apoios, os eventuais erros e omissões são de minha inteira responsabilidade. 


\section{RESUMO}

O foco do trabalho são as estruturas organizacionais de empresas conectadas às Cadeias Globais de Valor (Global Value Chains, GVCs) para acesso aos mercados no estrangeiro. O tema é estudado através do método de múltiplos casos. A amostra é composta por oito empresas de Tecnologia da Informação (TI), de origem brasileira, com atuação internacional, sobre as quais foram obtidas informações junto a fontes primárias. São apresentados conceitos que constam na literatura sobre GVCs, aperfeiçoamento competitivo, governança das cadeias, renda econômica e estratégia empresarial. A literatura indica que as estruturas das GVCs são modeladas por um pequeno grupo de empresas do hemisfério Norte. São verificadas as condições de governança das GVCs às quais os casos estão conectados Entre as questões de pesquisa está a investigação sobre como as empresas brasileiras podem desempenhar este papel de governança. O evento associado à governança, o chamado upgrading (aperfeiçoamento competitivo, no presente estudo), é relacionado à estratégia empresarial. $\mathrm{O}$ argumento é que estratégias sofisticadas trazem maior governança das GVCs às empresas, o que, por sua vez possibilita o aperfeiçoamento competitivo, o que melhora as chances de obtenção de renda econômica mais alta. São caracterizados os segmentos de mercado aos quais as organizações estudadas estão conectadas, bem como sua estratégia e comportamento com relação à inovação, principalmente organizacional. Os resultados indicam e comparam as estratégias e práticas quanto a desenvolvimento de produtos, terceirização de atividades, relacionamento com fornecedores, canais de distribuição e compradores no exterior. As estratégias e formas de atuação internacional dos casos estudados são comparadas. Todos os casos são classificados quanto à sofisticação de sua estratégia empresarial, possibilidades e limitações de obtenção de renda superior. 


\begin{abstract}
The focus of the research is the organizational structure of firms connected to Global Value Chains (GVCs). The investigation is conducted through the multiple case study method. The sample is composed of Information Technology (IT) firms of Brazilian origin. All of them carry international operations. Primary data were collected in personal interviews. The literature review brings concepts related to GVCs, upgrading, chain governance, economic rents and strategy. It's indicated in the literature that GVC structure is designed by northern hemisphere firms. The governance circumstances of the GVCs the studied firms are connected are examined. One of the research questions is how Brazilian companies can govern the GVCs they connect to. Upgrading is related to governance and to firm strategy. The argument is that proactive strategies can bring stronger governance to the companies, which allows upgrading and yields them higher economic rents. Market segments are characterized, as well as studied cases' strategy and attitude toward organizational innovation. Results show aspects and compare the global strategies of the investigated firms regarding product development, outsourcing, off shoring, relationship with suppliers, distribution channels and buyers. Studied organizations' strategy and management procedures in terms of international activity are compared. All the cases are classified regarding their corporate strategy proactive ness, possibilities and constraints to obtaining superior rents.
\end{abstract}




\section{SUMÁRIO}

Página

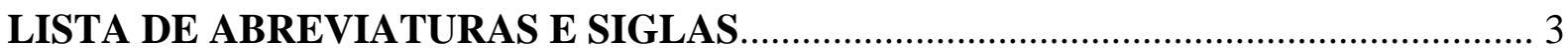

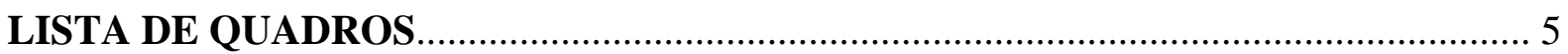

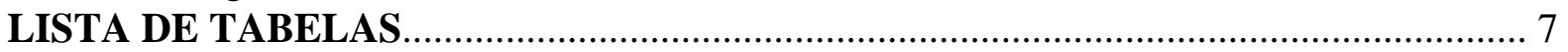

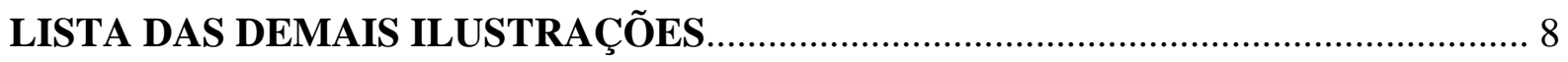

Capítulo 1 - O PROBLEMA ESTUDADO.................................................................. 9

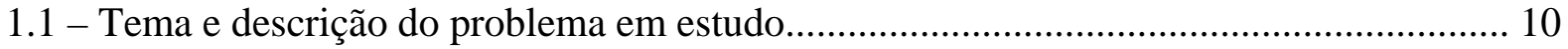

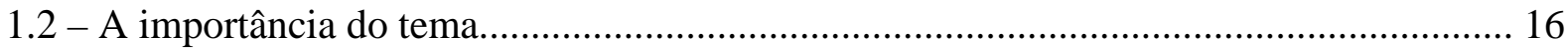

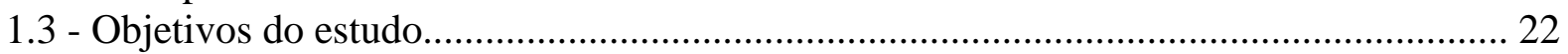

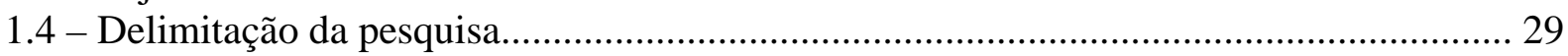

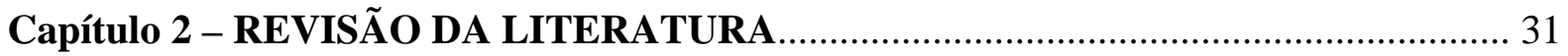

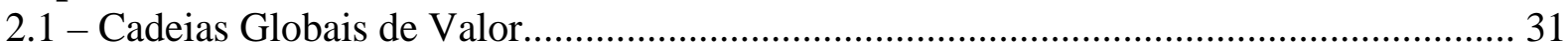

2.2 - Aperfeiçoamento competitivo, competitividade e capacitação........................................ 38

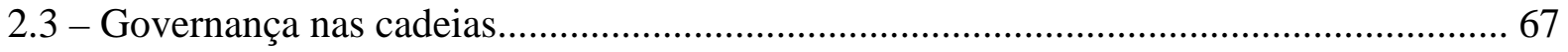

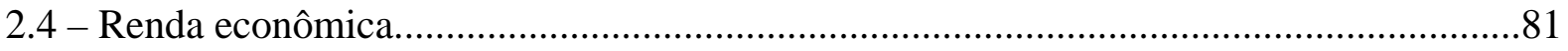

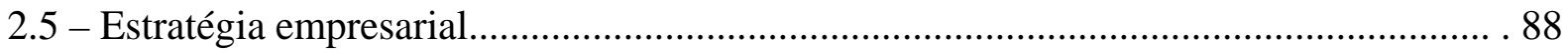

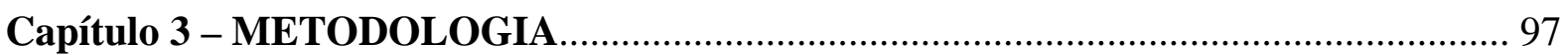

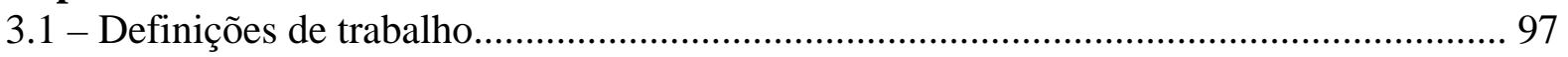

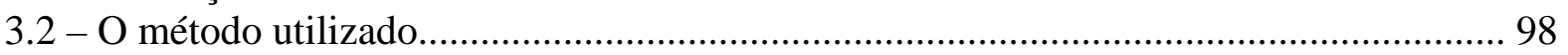

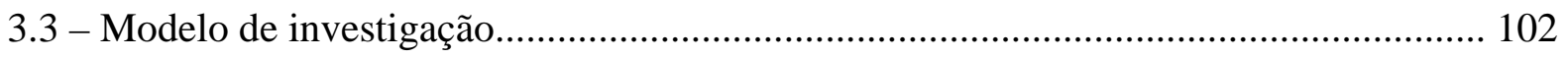

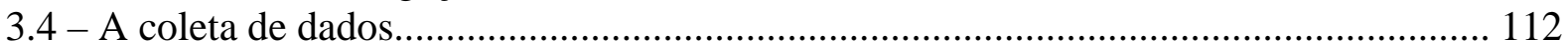

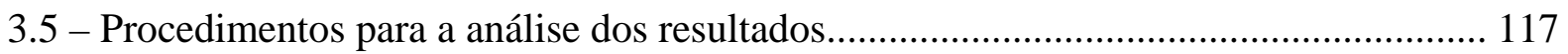

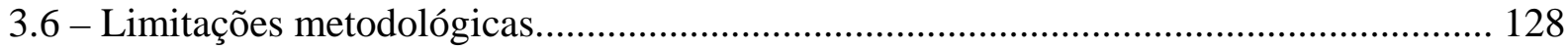

Capítulo 4 - DESCRIÇÃO DO SETOR E DAS ORGANIZAÇÕES ESTUDADAS E

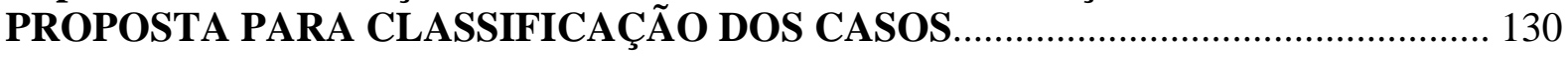

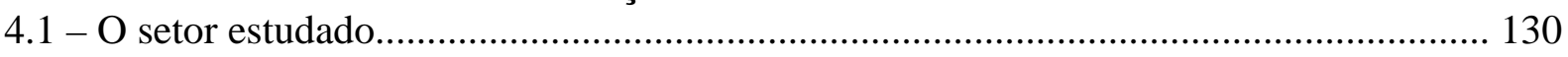

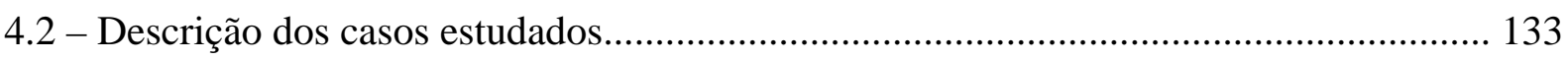

4.3 - Proposta de classificação dos casos estudados.......................................................... 151

4.4 - Operacionalização das relações apresentadas na hipótese............................................ 155

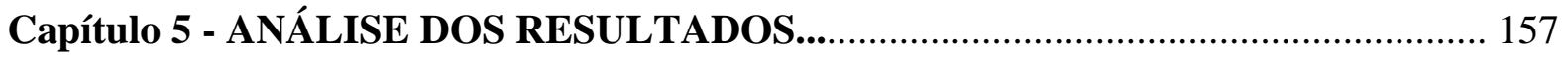

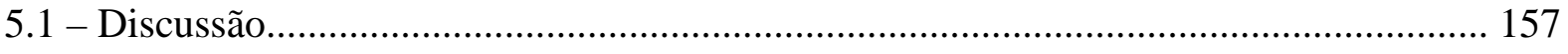

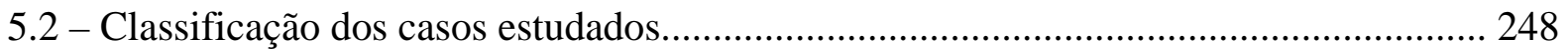

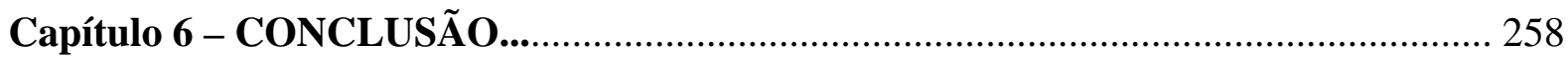

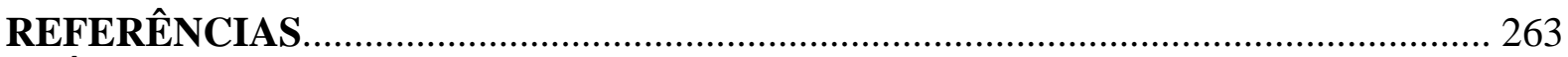

APÊNDICE 1 - Instrumento de pesquisa utilizado................................................. 274

APÊNDICE 2 - Comunicação enviada às empresas com lista de temas a serem

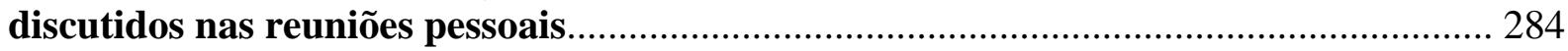


APÊNDICE 3 - Texto da carta enviada às empresas estudadas com a apresentação do

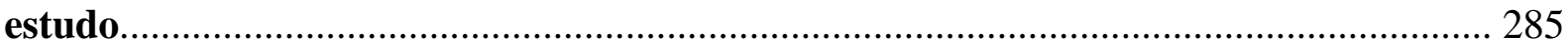




\section{LISTA DE ABREVIATURAS E SIGLAS}

ABES: Associação Brasileira das Empresas de Software

APL: Arranjo Produtivo Local

B2B: Business-to-business.

BCB: Banco Central do Brasil

BI: Business Intelligence

BNDES: Banco Nacional de Desenvolvimento Econômico e Social

BOVESPA: Bolsa de Valores de São Paulo

BPM: Business Process Management

BPO: Business Process Outsourcing

BRASSCOM: Associação Brasileira de Software e Serviços para Exportação

BSS: Processos de Negócios

CLT: Consolidação das Leis do Trabalho

CMMI: Capability Maturity Model Integration

CRM: Customer Relationship Management

CVM: Comissão de Valores Mobiliários do Brasil

CVP: Ciclo de Vida do Produto

ECM: Enterprise Content Management

ERP: Enterprise Resource Planning

EUA: Estados Unidos da América

FCS: Fatores Críticos de Sucesso

FINEP: Financiadora de Estudos e Projetos

GED: Gestão Eletrônica de Documentos

GVC: Global Value Chain ou Cadeia Global de Valor

HCM: Human Capital Management

IBGE: Instituto Brasileiro de Geografia e Estatística

IDC: International Data Corporation

IDE: Investimento Direto Estrangeiro

IED: Investimento Estrangeiro Direto

IPEA: Instituto de Pesquisa Econômica Aplicada

IPO: Initial Public Offering

ISSO: International Standards Organization

IV: Integração Vertical

LAJIRDA: Lucro Antes dos Juros, Depreciação e Imposto de Renda sobre o Lucro

LU: Licença de Uso

MCT: Ministério da Ciência e Tecnologia

MDIC: Ministério do Desenvolvimento, Indústria e Comércio

MNC: Empresa multinacional

NAFTA: North American Free Trade Agreement (Acordo Norte-Americano de Livre Comércio)

OBM: Original Brand Manufacturer

ODM: Original Design Manufacturer

OEA: Original Equipment Assembly

OEM: Original Equipment Manufacturer

ONG: Organização Não Governamental

OPA: Oferta Pública de Ações

OSS: Sistemas de Suporte à Operação

P\&D: Pesquisa e Desenvolvimento 
PME: Pequena e Média Empresa

$P N W$ : Rede verticalmente integrada.

PROSOFT: Programa para o Desenvolvimento da Indústria de Software e Serviços de TI RBV: Resource-Based View

RFP: Request for proposal

RE: Renda ou Rendimento Econômico

SaS ou SaaS: Software as service (software comercializado como serviço)

SIG: Sistemas Integrados de Gestão

SLA: Service Level Agreement

TI: Tecnologia da Informação

TNC: Empresa transnacional

TSE: Tribunal Superior Eleitoral

UN: Unidade de Negócios

VAR: Value- Added Reseller (revendedor de valor adicionado, do inglês)

VC: Vantagem Competitiva 


\section{LISTA DE QUADROS}

Quadro 1 - Variável independente, variável dependente e resultados.................................. 23

Quadro 2 - Atores das cadeias de valor e redes produtivas.................................................. 33

Quadro 3 - Exemplos de indicadores de inovação e aperfeiçoamento competitivo................ 46

Quadro 4 - Exemplos de bloqueadores e impulsionadores do aperfeiçoamento competitivo. 48

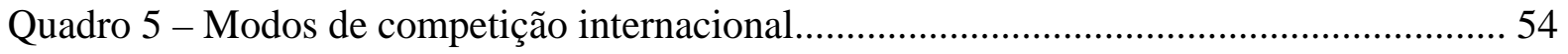

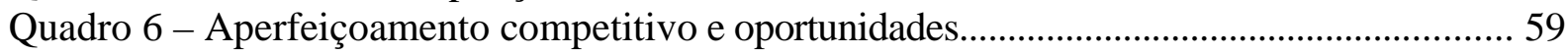

Quadro 7 - Tipos de governança em Cadeias de valor / Redes produtivas............................. 73

Quadro 8 - Fontes de obtenção de informação e técnicas utilizadas...................................... 115

Quadro 9 - Fontes de evidências utilizadas com seus respectivos pontos fortes e fracos..... 117

Quadro 10 - O processo de elaboração teórica a partir de estudos de caso............................ 125

Quadro 11 - Possíveis pontos de entrada na cadeia de valor............................................. 127

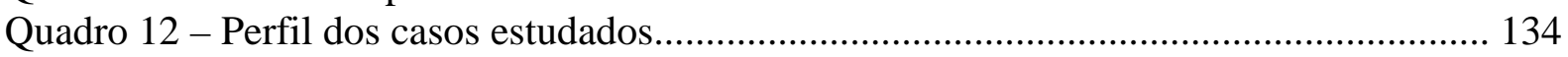

Quadro 13 - Classificação das empresas estudadas por porte.............................................. 135

Quadro 14 - Indicadores da sofisticação da estratégia empresarial e respectivas razões...... 152

Quadro 15 - Indicadores de limitações à obtenção de renda econômica superior e respectivas razões.

Quadro 16 - Indicadores de possibilidade de obtenção de renda econômica superior e

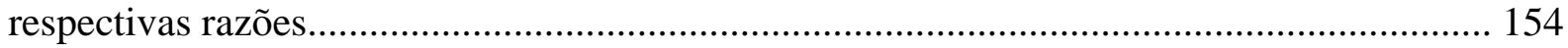

Quadro 17 - Esquema proposto para a classificação das empresas estudadas...................... 156

Quadro 18 - Casos estudados - Apresentação comparativa quanto a produtos.............................. 157

Quadro 19 - Papel do marketing e da construção de marcas................................................. 158

Quadro 20 - Características do modelo de atuação e conseqüências quanto à flexibilidade 159

Quadro 21 - Renda econômica e governança nas cadeias nas quais as empresas estudadas

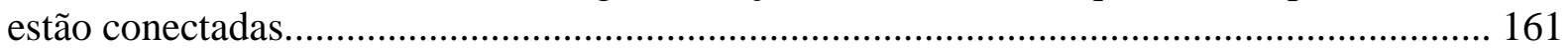

Quadro 22 - Atividades no exterior dos casos estudados.................................................... 163

Quadro 23 - Características da operação em cadeias de valor das empresas estudadas........ 165

Quadro 24 - Distribuição das atividades em empresas e países nos casos estudados............ 168

Quadro 25 - Identificação dos atores nas cadeias dos casos estudados................................ 172

Quadro 26 - Forma de evolução das ligações entre as empresas........................................ 176

Quadro 27 - Motivos das transferências das atividades ao exterior..................................... 179

Quadro 28 - Qualidade da participação dos casos estudados no sistema global de

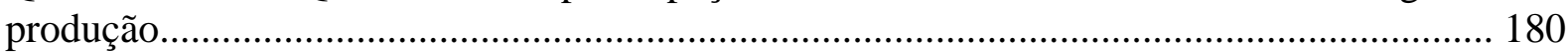

Quadro 29 - Componentes da renda econômica e barreiras à entrada................................. 184

Quadro 30 - Formas de obtenção da competitividade pelos casos estudados - Porte........... 189

Quadro 31 - Formas de obtenção da competitividade pelos casos estudados -

Flexibilidade......

Quadro 32 - Classificação dos casos estudados quanto a aspectos da vantagem

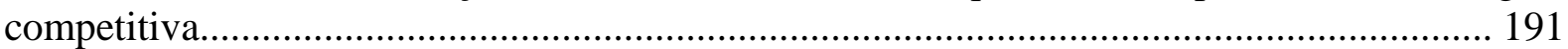

Quadro 33 - Classificação dos casos quanto ao aperfeiçoamento competitivo...................... 193

Quadro 34 - Exemplos de indicadores de inovação e aperfeiçoamento competitivo nos casos

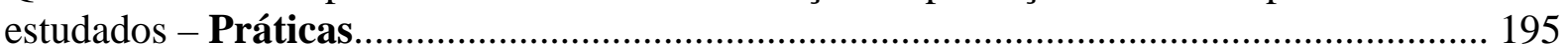

Quadro 35 - Exemplos de indicadores de inovação e aperfeiçoamento competitivo nos casos estudados - Desempenho.

Quadro 36 - Atributos da inovação que devem ser considerados em empresas de países em

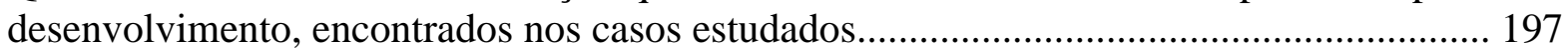

Quadro 37 - Nível de aprendizado dos casos estudados com empresas internacionais........ 200

Quadro 38 - Estrutura para aproveitamento do conhecimento obtido internacionalmente... 202 
Quadro 39 - Abordagem das empresas estudadas quanto a competir no fator preço............ 204

Quadro 40 - Classificação dos casos quanto à forma de competir....................................... 206

Quadro 41 - Classificação dos casos estudados quanto à exportação.................................... 210

Quadro 42 - Origem da vantagem competitiva nos casos estudados................................... 213

Quadro 43 - Opções estratégicas utilizadas pelos casos estudados para combater o

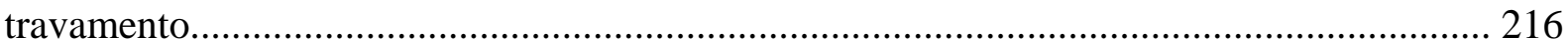

Quadro 44 - Segmento-foco da atuação das empresas estudadas....................................... 217

Quadro 45 - Classificação dos casos estudados quanto à utilização de marcas próprias ou de

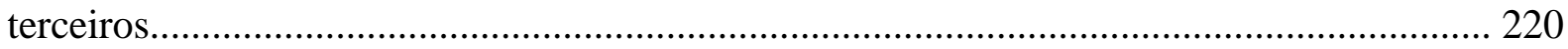

Quadro 46 - Aperfeiçoamento competitivo e oportunidades nos casos estudados............... 220

Quadro 47 - Nível das barreiras à entrada de concorrentes nos casos estudados e respectiva

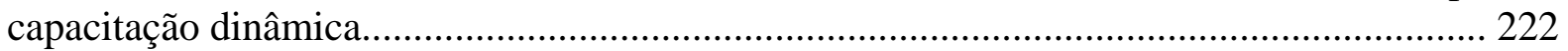

Quadro 48 - Evidências do aperfeiçoamento competitivo (AC) fora da esfera produtiva.... 226

Quadro 49 - Evidências de pouco compromisso com o passado nos casos estudados......... 232

Quadro 50 - Intento estratégico - Objetivos e processos de gestão para sua transformação em

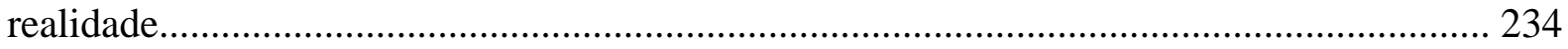

Quadro 51 - Classificação das cadeias das quais participam as empresas estudadas........... 235

Quadro 52 - Gerenciamento das cadeias de valor nos casos estudados............................... 239

Quadro 53 - Características dos casos estudados para geração de renda econômica

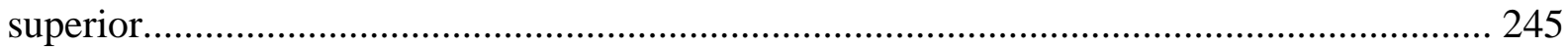

Quadro 54 - Classificação dos casos estudados quanto à sofisticação da estratégia

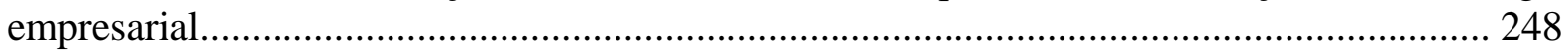

Quadro 55 - Classificação dos casos estudados quanto às limitações à obtenção de renda

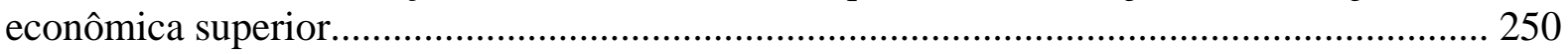

Quadro 56 - Classificação dos casos estudados quanto às possibilidades de obtenção de renda econômica superior pelos casos estudados.................................................................. 252

Quadro 57 - Resumo geral quanto à sofisticação da estratégia empresarial, limitações e possibilidades de obtenção de renda econômica superior...................................................... 254

Quadro 58 - Classificação dos casos estudados conforme proposta inicial........................... 255 


\section{LISTA DE TABELAS}

Tabela 1 - Casos estudados - Informações sobre as entrevistas realizadas.......................... 102

Tabela 2 - Detalhamento da movimentação financeira de TI no Brasil.............................. 132

Tabela 3 - Software e serviços no Brasil em 2006............................................................... 132

Tabela 4 - Categoria de produtos em software e serviços no Brasil com volumes

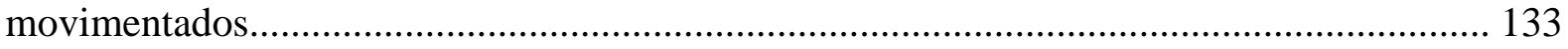

Tabela 5 - Receitas brutas das organizações estudadas - Percentuais de crescimento do ano 2007 comparado com ano 2006. 


\section{LISTA DAS DEMAIS ILUSTRAÇÕES}

Ilustração 1 - Relação entre sofisticação da estratégia e renda econômica (RE).................... 24

Ilustração 2 - Limitações à obtenção de renda econômica superior........................................ 25

Ilustração 3 - Limitações à obtenção de renda econômica superior: estratégia empresarial

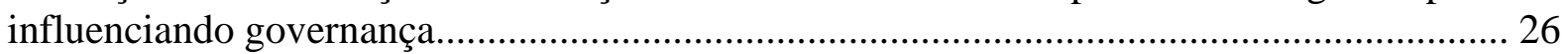
Ilustração 4 - Modelo para obtenção da vantagem competitiva no nível

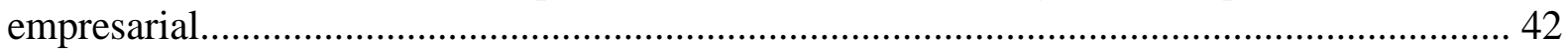

Ilustração 5 - Seqüência de aperfeiçoamento competitivo em cadeias de valor...................... 59

Ilustração 6 - Fatores estratégicos para o aumento da renda econômica.................................. 81

Ilustração 7 - Características desejáveis dos recursos e capacitações da empresa (para geração

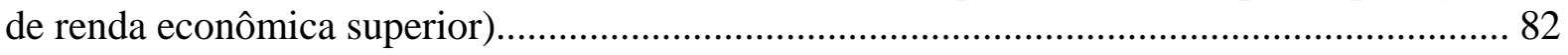

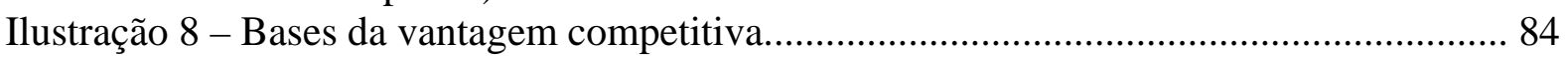

Ilustração 9 - Vantagem competitiva sustentável.............................................................. 91

Ilustração 10 - Um modelo organizacional baseado em competências................................... 93

Ilustração 11 - Componentes e lógicas do modelo de investigação...................................... 103

Ilustração 12 - Os três níveis no universo da ciência............................................................. 121

Ilustração 13 - Esquema para classificação das empresas estudadas (operacionalização).... 155

Ilustração 14 - Como as empresas estudadas se conectam aos mercados finais (exterior)....170 


\section{Capítulo 1 - O PROBLEMA ESTUDADO}

O problema estudado está relacionado às estratégias empresariais das empresas dos países em desenvolvimento. Os temas principais aqui tratados são: o aumento da competição, a necessidade de concorrer com base na inovação, os obstáculos para que a empresa se renove continuamente, sejam estes obstáculos internos ou afetos ao modo de relacionamento com outras organizações.

$\mathrm{Na}$ atualidade, o ambiente competitivo para a maior parte das empresas, independente do porte, na maioria dos países, guarda pouca semelhança com o que ocorria antes de 1980. Dois fatores, em larga escala, explicam esta mudança: (1) Nas décadas de 1980 e 1990 a produção ${ }^{1}$ se tornou mais intensiva em conhecimento em um amplo espectro de setores (e.g. empresas de pesca nas Filipinas e no Chile, empresas de reflorestamento e flores no Quênia e na Colômbia, até empresas moveleiras, têxteis e de confecções na Dinamarca, Taiwan e Tailândia). (2) A concorrência se tornou global e mais baseada na inovação. Desta forma, as empresas dos países em desenvolvimento devem cada vez mais aderir a um processo contínuo de inovação, independente do setor no qual operam. A dependência das empresas com relação aos hábitos e práticas do passado (path dependence) não estimula este comportamento inovador. Há uma necessidade urgente de novas abordagens com relação a como empresas adormecidas podem se tornar concorrentes cheios de dinamismo. (MYTELKA, 2000, p. 15).

O argumento é que a globalização da produção não pode ser explicada simplesmente como uma realocação da produção, que deixa os países desenvolvidos e vai à direção dos países em desenvolvimento, à procura de custos de mão-de-obra mais baixos. Inovações tecnológicas nos processos de produção e distribuição fazem parte da equação estratégica, visto que influenciam, entre outras coisas, a velocidade da respostas às alterações dinâmicas na demanda dos compradores. Estas, por sua vez, são intensamente influenciadas pela dominância das grandes empresas. Grandes empresas, em alguns setores, estão se tornando, a cada dia, mais importantes. São elas as únicas que tem condição de investir em novas tecnologias ou construir marcas de prestígio global baseada na comunicação de massa. Há uma inquestionável tendência à concentração crescente (DICKEN, 1998, p. 303-305).

\footnotetext{
${ }^{1}$ Produção, no contexto deste trabalho, não significa necessariamente fabricação de um bem. Na verdade, visto serem todas as empresas estudadas empresas de serviços - uma delas se dedica também à fabricação de equipamentos - produção na maior parte dos casos não é fabricação.
} 


\section{1 - Tema e descrição do problema em estudo}

A abordagem utilizada neste trabalho enfatiza o papel da empresa, em especial a sua estratégia. Esta abordagem está alinhada com o que preconiza Foss (1993, p. 275), que conclui que, ao eleger a transação como unidade analítica, as teorias construídas sobre uma tradição coasiana, são excessivamente propensas a negligenciar o papel da empresa como uma entidade histórica diferenciada, caracterizada por ser uma base de conhecimento que se altera com dependência de seu passado e sofre influência de contingências inesperadas. Ao negligenciar o papel da empresa, fica prejudicada a compreensão na íntegra do significado do termo estratégia empresarial.

Além da abordagem empresarial, há foco na relação entre as empresas, daí a utilização do construto da cadeia de valor. Schmitz (1999B, p. 1628) aponta que uma convergência entre várias escolas de pensamento é a necessidade de foco nas relações entre empresas e não somente na firma individual. Vellinga (2000, p. 7) nota a importância da abordagem de Gereffi (2000, p. 32), que vai além do debate mercado versus estado e apresenta a organização da produção como um fator crucial atrás do processo de transformação econômica que resulta da globalização.

O foco da pesquisa são as empresas e redes de empresas, portanto é uma abordagem organizacional. A pesquisa se desenvolve no chamado nível meso, composto por países e empresas e que são classificados por Gereffi (2005, p. 160, tradução nossa) como “os alicerces da economia global”. Duguid (2005, p. 494-495) destaca a importância das redes de mercadorias para a história empresarial. Gwynne (2004, p. 248) também nota que o estudo da inserção global de empresas nacionais através das redes de valor deveria ser mais desenvolvido.

Gibbon e Ponte (2005, p. 74-75 e 84) comentam a contribuição de Gereffi e Korzeniewicz (1994), pois neste trabalho a maior parte dos colaboradores estava ainda preocupada com as cadeias de valor, que então recebiam o rótulo commodity chains. Mais recentemente, o termo commodity chain foi abandonado e o termo value chain tomou o seu lugar. Este último termo sugere um escopo de produtos mais amplo, alguns dos quais não têm as características de 
commodities (pode ser traduzido como mercadorias, para designar produtos manufaturados com pouca ou nenhuma diferenciação).

Gibbon e Ponte (2005, p. 205) além de reconhecerem a contribuição de Gereffi, apontam falta de maior esclarecimento da dinâmica da emergência do padrão de governança dirigido pelo comprador. Também é notada a falta de prescrições (para as empresas) e projeções para o futuro.

Este trabalho aborda como as empresas estudadas podem aderir às Cadeias Globais de Valor (Global Value Chains, GVCs) em condições mais fortes de governança. Gibbon e Ponte (2005, p. X-XI) afirmam que as estruturas das Cadeias Globais de Valor são fortemente modeladas pelas estratégias de pequenos grupos de empresas no hemisfério Norte. A partir desta constatação, são colocadas as seguintes questões: Será que estas estruturas devem ser obrigatoriamente modeladas a partir do Norte? Como algumas empresas brasileiras poderiam desempenhar este papel?

Em termos de aperfeiçoamento competitivo² ${ }^{2}$ Humphrey e Schmitz (2000, p. 15) colocam uma questão intrigante: se este aperfeiçoamento é tão fácil, porque não tem ocorrido com mais freqüência nos países em desenvolvimento? É justamente este o ponto que esta pesquisa aborda. Primeiro, há o reconhecimento de que o aperfeiçoamento competitivo não ocorre de forma automática para as empresas de países em desenvolvimento. Segundo, associa o evento à sofisticação da estratégia empresarial.

Este trabalho trata das relações de poder nas GVCs. Há a associação entre estratégia mais sofisticada e maior poder na cadeia. Gibbon e Ponte (2005, p. 84) notam que uma das qualidades mais destacadas da abordagem GVC é precisamente a inclusão do conceito de poder nas relações econômicas e transações. Gibbon e Ponte (2005, p. 91) também colocam que uma maneira de esclarecer as relações entre governança e aperfeiçoamento funcional nas GVCs é através da análise empírica detalhada, isto é, analisando cada cadeia em particular, de forma a identificar papéis concretos que possibilitam aos fornecedores renda econômica mais alta e estável, bem como as rotas que são tipicamente usadas para chegar a estes papéis. O

\footnotetext{
${ }^{2} \mathrm{O}$ termo upgrading foi traduzido neste trabalho por aperfeiçoamento competitivo.
} 
escopo deste trabalho converge com esta noção, de que é possível haver ação gerencial para desempenhar estes papéis.

Para o estudo do problema apresentado, é utilizada a abordagem da cadeia de valor, a qual possibilita uma estrutura analítica abrangente para as reações conjuntas dos envolvidos. Isto obriga a uma consideração mais ampla, dinâmica e estratégica das questões relacionadas ao tema.

Williamson (1985, p. 68) observa a variedade de formas de contratação possível. Esta variedade existiria devido às diferenças existentes nos atributos das transações objeto dos contratos. O propósito de se atingir eficiência é perseguido através da adequação da estrutura de governança aos atributos das transações. Aqui neste trabalho, o argumento é que além destas considerações sobre eficiência, fenômenos como a questão da distribuição dos resultados, são influenciados pela governança nas relações entre as empresas. Williamson (2002, p. 1110) relaciona as formas de governança ao conceito de dependência do passado, que deveria ser considerado para a investigação da estrutura mais adequada a ser utilizada pela empresa.

Se a obtenção de renda econômica superior for associada com o desempenho extraordinário, chega-se aos argumentos de Dunning (1995, p. 4-5), que nota ao procurar razões este desempenho, o sucesso da empresa moderna é crescentemente determinado pela habilidade de organizar recursos através de fronteiras nacionais, não só dentro (da empresa), mas também com outras organizações. Dunning (2000, p. 10-11) também deixa registrado que uma das características mais interessantes das economias de mercado líderes, nos tempos recentes, têm sido a extensão em que a forma hierárquica de governança, de organizações públicas e privadas, tem sido complementada, e até em alguns casos substituída, por uma variedade de arranjos cooperativos inter-organizacionais. Este crescimento das alianças entre empresas é creditado ao aumento do chamado capitalismo do conhecimento.

Williamson (1991B, p. 81) também trata do assunto ao afirmar que é freqüente o estudo da empresa moderna através do exame das alternativas formas organizacionais. Contudo, muitas vezes isto compreende apenas o estudo de uma forma genérica de governança, a hierarquia. No entanto, o veio de pesquisa da economia do custo de transação propõe que comparações 
entre os modos genéricos de governança - mercados, híbridos e hierarquia - é de grande importância.

O problema estudado já vem sendo tratado na literatura por pelo menos duas décadas. Kogut (1985, p. 30) utiliza o exemplo dos fabricantes japoneses de aparelhos de TV. Na época, embora a participação de mercado dos fabricantes japoneses tivesse crescido, a fragilidade destas empresas em marketing, distribuição e serviço pós-venda trouxe à tona a questão de quem recebia os lucros. Contudo, deve ser observado que este estudo tratava de empresas de país, já naquela época, desenvolvido. Aqui, o estudo trata de algumas empresas do Brasil, que pode ser classificado como país em desenvolvimento.

Esta questão da piora relativa das empresas dos países em desenvolvimento é tratada também por Kaplinsky (2000, p. 118-120). É mencionado que, desde meados da década de 1980, se observa uma tendência de queda dos termos de comércio dos bens produzidos pelos países em desenvolvimento. Este declínio nos termos de comércio dos países em desenvolvimento coincide com a entrada da China no comércio mundial. Além de afetar nações, a questão dos retornos decrescentes tem impacto em empresas. A conseqüência do fracasso das empresas, grupos de empresas e economias nacionais de se inserirem de forma apropriada nos mercados globais é que pode ocorrer uma situação na qual há crescente atividade econômica e queda de retorno econômico. Observa-se que isto ocorreu para os produtores brasileiros de calçados nos últimos 25 anos.

A argumentação de Kaplinsky (2000, p.126-127 e 143) é que as exigências dos mercados finais de produtos nos mercados de alta renda invariavelmente pedem capacitações que estão fora do alcance de indivíduos menos favorecidos economicamente e de PMEs (Pequenas e Médias Empresas). Contudo, este ponto de vista é questionado neste trabalho. A apropriação da renda econômica sofre alterações ao longo do tempo. É notado que o principal impulso da preocupação da distribuição de ganhos é existência de competição, que diminui lucros ao reduzir as barreiras de entrada. A diminuição de barreiras de entrada se intensifica à medida que mais e mais países participam do comércio global.

O esforço deste trabalho está centrado em como a empresa pode obter vantagem competitiva sustentável e renda econômica superior. Ao longo dos anos, este tema vem sendo tratado na literatura sobre estratégia empresarial: Amit e Schoemaker (1993, p. 33) afirmam que, para os 
gestores, o desafio está na identificação, desenvolvimento, proteção e utilização dos recursos e capacitações que possibilitam à empresa uma vantagem competitiva sustentável e, portanto, renda econômica superior. Teece et al (1997, p. 509) também abordam o tema ao afirmar que a questão fundamental em gestão estratégica é: como as empresas obtêm e mantêm vantagens competitivas? De acordo com a visão baseada em recursos (Resource Based View, RBV), as vantagens competitivas seriam obtidas a montante dos mercados de produtos e estão baseadas nos recursos específicos e de difícil imitação detidos pela empresa (TEECE ET AL, 1997, p. 513). O debate existe. Schmitz (1999B, p. 1628) argumenta que, embora haja uma convergência com relação à questão crítica sobre quem perde e quem ganha com a globalização, há controvérsia sobre o que possibilita às empresas desenvolverem vantagens competitivas sustentáveis que lhes tragam renda econômica crescente.

Humphrey e Schmitz (2000, p. 3) apontam que também as empresas nos países em desenvolvimento, a exemplo das firmas em todos os lugares, estão sob pressão para melhorar seu desempenho e serem mais competitivas. Novos produtores com custos baixos entram no mercado mundial a todo instante, intensificando a competição em mercados de produtos intensivos em mão-de-obra. O problema em estudo tem foco na questão de como empresas em países em desenvolvimento respondem a este desafio e ao mesmo tempo obtém renda econômica superior para o trabalho e para o capital envolvidos no processo. A literatura sobre competitividade sugere que a reação mais viável é o chamado aperfeiçoamento competitivo (upgrading) - fazer produtos de maneira mais eficiente e acrescentar valor através da oferta de produtos mais sofisticados, que são elaborados através de processos idem.

Teece et al (1997, p. 526-528) ao concluir sobre as diferenças dos paradigmas da estratégia, afirmam que há benefícios em todas as abordagens. Não se deve ficar aderir de maneira automática a um dos paradigmas. No paradigma das forças competitivas, a ênfase é no papel da estratégia, como neste trabalho. Nas abordagens das capacitações dinâmicas e $R B V$, a vantagem competitiva vem de dentro da empresa, como também argumenta este trabalho. A diferença está que aqui se procurar unir as abordagens, visto que se acredita que a estratégia, junto com a história, tem um papel na determinação do caminho a ser percorrido pela empresa.

Há controvérsias sobre o que leva as empresas ao desempenho superior. Este trabalho procurar dar uma contribuição para esta discussão. Com relação às empresas, Bernard e 
Jensen (1997, p. 2-3 e 16-17) argumentam que está provado que as empresas exportadoras têm desempenho superior as que não são exportadoras. A produtividade, entre outros fatores, seria superior em qualquer momento analisado. Contudo, também se notou que as empresas que se tornarão exportadoras no futuro, exibem desempenho melhor muitos anos antes de se envolverem com o mercado internacional. Não está claro qual o benefício de exportar para uma empresa fora deste grupo de desempenho diferenciado.

Nesta pesquisa, ao se relacionar estratégia, desenvolvimento de capacitações dentro da empresa e foco nas cadeias produtivas globais, ocorre um alinhamento com a abordagem utilizada por Lane e Probert (2006, p. 37), em estudo sobre empresas do setor de confecções, onde o argumento é que o poder que exercem nas cadeias é influenciado, de forma decisiva, pelas suas capacitações desenvolvidas internamente.

Se há algum tempo vantagens como escala eram fundamentais para a competitividade, na atualidade há outros fatores. A investigação aqui desenvolvida está relacionada a estes novos fatores. As pesquisas de Maskell e Malmberg (1999, p. 167) vão na mesma linha ao afirmar que mudanças na economia internacional têm gradualmente alterado a base da competitividade de empresas. As mudanças vão na direção do aperfeiçoamento dinâmico, de forma a beneficiar empresas que tem capacidade de criar conhecimento mais rápido do que seus concorrentes. A competitividade sustentável exige a reposição contínua de recursos decrépitos.

Este trabalho argumenta que a criação de renda econômica superior depende da elaboração da estratégia empresarial. Teece et al (1997, p. 509) afirmam que a criação de renda superior em regimes de rápida mudança tecnológica depende em larga medida do aperfeiçoamento de processos organizacionais e de gestão, que ocorrem dentro da empresa.

Também de acordo com Teece et al (1997, p. 515), a visão baseada nas competências dinâmicas argumenta que em um mercado global, as empresas bem sucedidas são aquelas que reagem de forma tempestiva e contam com o desenvolvimento de produtos ágil e flexível em conjunto com a capacitação gerencial de coordenar e redirecionar com eficácia competências internas e externas. 
Hauge (2006, p. 1 e 19) argumenta que as inovações de produto e organizacionais são os elementos básicos para o crescimento econômico e para a prosperidade. O raciocínio é que a competitividade está relacionada à capacidade das empresas aperfeiçoarem continuamente sua base de conhecimento e desempenho. Daí resulta que o conhecimento é um ativo fundamental para as empresas competitivas e o aprendizado é um processo da maior importância. A inovação é mais bem compreendida como um processo social e as relações entre os atores são críticas no entendimento de como as empresas obtêm vantagens competitivas.

A idéia da empresa como mais do que uma função de produção, de forma a enfatizar a gestão e a organização, é também enfatizada pela perspectiva das competências, vista como complementar da governança. (WILLIAMSON, 2002, p. 1100 e 1120).

\section{2 - A importância do tema}

O tema escolhido é relevante, pois como mencionam Sturgeon e Florida (2000, p. 1), há falta de estudos sobre a globalização no nível setorial e das empresas. Jones (2002, p. 581-583) adiciona que, embora o tema globalização tenha sido muito estudado, o papel da empresa neste processo, em comparação com as forças macroeconômicas, ainda não recebeu suficiente atenção. Entre as questões que permanecem por ser investigadas, está o papel da multinacional oriunda dos chamados mercados emergentes e a importância de alguns setores de serviços. A sugestão - aqui acatada - é que o comportamento das empresas seja estudado. A teoria da empresa multinacional, ainda nos tempos contemporâneos, permanece desproporcionalmente preocupada com as grandes empresas manufatureiras de alta tecnologia.

Mesmo com a existência de estudos sobre o tema em empresas oriundas dos países desenvolvidos, a investigação sobre empresas de países em desenvolvimento importa, pois como Hunter (2005, p. 278) argumenta com ênfase, em sociedades e culturas diferentes, arranjos institucionais e normas societais distintas, bem como variadas formas de atividade comercial são engendradas e desta forma, são estimuladas diferentes respostas gerenciais.

Williamson (1975, p. 248) nota que a discussão entre mercado e necessidade de hierarquia precisa considerar os tipos específicos de mercado e de organização. Os tipos de mercados apresentam 
variedade considerável com respeito às condições de entrada, distribuição do tamanho das empresas e outros fatores.

As pequenas e médias empresas (PMEs) são tratadas neste trabalho. Esta escolha está relacionada ao que nota Mytelka (2000, p. 20-21) sobre as pequenas e médias empresas, que são atores numericamente significantes nos países em desenvolvimento e sua importância no contexto de um emergente sistema de inovação local é, com freqüência, esquecido. O crescimento de muitas economias da Ásia foi impulsionado pelas PMEs atuando como subcontratadas de clientes do exterior ou de empresas locais maiores. Algumas destas empresas se transformaram em inovadores dinâmicos. Os setores tradicionais também estariam demonstrando novo dinamismo. São citados estudos que fundamentam a visão de que a inovação não é exclusividade de setores baseados na ciência.

Este comércio através de redes de empresas tem crescido em importância nas últimas décadas. Humphrey e Schmitz (2004, p. 96-97) recordam que o volume de comércio internacional na forma de transações entre as subsidiárias de multinacionais é acompanhado há tempos pelos pesquisadores. Contudo, mais recentemente tem se dado atenção ao comércio que é organizado através de redes de empresas independentes do ponto de vista legal. Este comércio lança mão de várias transações relacionais. A pesquisa de cadeias globais de valor ambiciona compreender a natureza destas relações.

Também Dicken et al (2001, p. 89 e 98-99) pesquisaram o tema e consideram que a metodologia da Cadeia Global de Valor (Global Value Chains, GVCs) é útil para o entendimento da economia mundial. É observado que o tema das cadeias não é suficientemente explorado nos seus detalhes, seja do ponto de vista conceitual, seja do ponto de vista empírico. Há o reconhecimento que os trabalhos de Porter da década de 80 são seminais neste sentido, embora exista a crítica de que esta abordagem é abundante em prescrição e pouco analítica. Também se reconhece que a tentativa mais ambiciosa e consistente de desenvolvimento do conceito de cadeia como ferramenta de análise da economia global é a de Gereffi (1994, 1996 e 1999). A crítica ao trabalho de Gereffi, entre outros aspectos, é o escopo de casos empíricos examinados na literatura de cadeias produtivas globais permaneceria extremamente limitado. 
A resposta organizacional às novas condições (volatilidade dos mercados, encurtamento dos ciclos de vida dos produtos e aumento dos custos de inovação) também é destacada por Berger et al (1999, p. 3-5). A preocupação das pesquisas sobre organização industrial mudou da lógica e ramificações das estruturas externas, para as economias externas criadas pela interação entre as empresas. Este novo foco é rotulado de paradigma das redes de valor. A característica em comum destas redes é a realização de economias externas de escala e escopo ao se apoiar em formas fragmentadas (em comparação às formas verticalmente integradas) de organização industrial.

Dedrick e Kraemer (1998, p. v-vi) ao estudarem a indústria de computadores pessoais na Ásia, identificaram um novo fator que não estava incorporado nas explicações prévias: a emergência da rede global de produção. O desempenho das empresas estudadas estava correlacionado à qualidade de sua integração a estas cadeias. Quanto aos países, seu desempenho estava relacionado ao portfólio capacitação de suas empresas no setor. Juntas, estas forças criavam dependências do passado, que influenciavam a trajetória das empresas e dos países. O caso das empresas latino-americanas é considerado semelhante na literatura: Bradford Jr. (1994, p. 89), ao tratar destas economias, conclui que uma questão crítica é como aumentar a integração às redes globais.

A opção por um setor novo, como o de tecnologia da informação (TI) se justifica, pois como Hunter (2005, p. 279) nota, pouco se sabe em cadeias global de valor que não estão claramente definidas. Um dos exemplos são redes para novos produtos, resultantes da inovação por empreendedores que buscam estabelecer um mercado ao invés de servir um que já existe. É necessário investigar como estas redes se modificam ao longo do tempo, à medida que se tornam mais rígidas e estabelecidas.

Conolly et al (2005, p. 149-150) ao estudarem cadeias de valor, argumentam que no nível internacional, uma nova dimensão de desafios e oportunidades é adicionada (às empresas). Também é notada a pouca exploração teórica do tema em periódicos que publicam pesquisas sobre gestão e estratégia.

Henderson (1996, p. 403 e 408) entende que os processos de integração transformaram radicalmente a natureza da organização empresarial e suas estratégias, entre outros aspectos. A conclusão é que à abordagem da cadeia global de valor falta o estudo da organização 
econômica capitalista, a empresa. Hunter (2005, p. 277-278) adiciona que o construto da cadeia global de valor permite um exame das relações transnacionais. Também se critica a análise da cadeia global de valor no que ela reflete a abordagem determinística com relação ao comportamento empresarial. De acordo com esta crítica, as empresas ligadas em cadeias, conectadas a processos sociais e culturais, cercadas por normas institucionais e mercados de trabalho estruturados, teriam pouco espaço para a resposta individualizada. A contribuição deste trabalho procura superar esta crítica à abordagem da cadeia global de valor.

Lester (2003, p. 10), em estudo sobre os efeitos da globalização na economia dos EUA, propõe que uma das questões que deve ser respondida é como as formas organizacionais criam e capturam valor nas novas redes globais de produção.

Kaplinsky e Morris (2003, p. 15 e 22) notam a importância de se investigar como as empresas e países se inserem na economia global. Esta seria a questão fundamental. A abordagem da cadeia de valor seria um ponto de entrada fundamental nesta investigação, pois procura desvendar a natureza e os determinantes da competitividade, além de contribuir para ampliar os horizontes, ao passar da empresa individual para o grupo de empresas inter-relacionadas.

Conforme Kaplinsky e Morris (2003, p. 14 e p. 25), uma das razões da importância da abordagem da cadeia de valor é a sua contribuição para explicar a distribuição dos benefícios, em particular da renda econômica, para àqueles que participam da economia global. A cadeia de valor é um construto importante para se entender a distribuição de retornos que advém do design ${ }^{3}$, da produção, do marketing e das atividades de coordenação, para citar alguns exemplos.

De acordo com Giuliani et al (2005, p. 552), é o êxito no aperfeiçoamento ao nível da firma que permite a aquisição dinâmica de competitividade em novos nichos de mercado, setores ou fases da cadeia produtiva.

Kaplinsky e Morris (2003, p. 9) enumeram três conjuntos de razões pelas quais a abordagem da cadeia de valor é importante na atualidade, onde a globalização ocorre de forma acelerada:

\footnotetext{
${ }^{3}$ Em geral, os termos design e desenvolvimento foram utilizados sem distinção neste trabalho. São utilizados para fazer referência a desenvolvimento de produto. Nas situações em que design é utilizado para fazer referência ao estilo do produto, o leitor é avisado.
} 
1. Com a crescente divisão do trabalho e dispersão global da produção dos componentes, a competitividade sistêmica tem assumido importância crescente.

2. Eficiência produtiva é somente uma condição necessária para se penetrar com sucesso nos mercados globais.

3. A entrada nos mercados globais, que permite o crescimento sustentado da renda econômica, requer a compreensão dos fatores dinâmicos dentro da cadeia de valor.

Humphrey e Schmitz (2002, p. 27) notam que os produtores de países em desenvolvimento se encontram crescentemente conectados nas redes globais de valor controladas pelos compradores globais, ou seja, não governam estas cadeias. Embora estes e outros autores aqui mencionados abordem o problema, há carência de estudos que indiquem como surge esta governança e como empresas de países em desenvolvimento podem agir, em termos gerenciais, para ter uma posição mais favorável nestas relações.

No entanto, Schmitz e Knorringa (1999, p. 3) argumentam sobre a importância de revelar os fatores críticos de sucesso para o aperfeiçoamento competitivo. Este tema seria de espacial relevância para os países em desenvolvimento. Um ponto importante é que mesmo se houvesse uma liberalização imediata e total do comércio entre países desenvolvidos e em desenvolvimento, estes últimos não obteriam acesso automático aos mercados internacionais. A razão disto é que as redes nas quais os produtores estão conectados são governadas por um número limitado de compradores. Portanto, o entendimento da forma pela qual a governança das cadeias influencia as perspectivas dos fornecedores parece crítica. No entanto, deve ser lembrado que a capacitação dos fornecedores e a governança das cadeias é dinâmica, ou seja, se altera ao longo do tempo.

A importância do conceito de cadeias (ou rede de negócios, como o chamam) também é notada por Rugman e D’Cruz (2000, p. 62) quando propõem que sua utilização pode amenizar os custos inerentes ao oportunismo que existe nas transações classificadas como de mercado e ao mesmo tempo a especificidade de ativos existente nas hierarquias.

Williamson (1985, p. 15-16) já destacava a importância dos detalhes relativos à organização. É importante também o exame das características estruturais do mercado, como hierarquia ou formas que se assemelham às transações de mercado e sua relação com as conseqüências 
econômicas de forma sistemática. A empresa, mais do que uma função de produção, deve ser conceituada como uma estrutura de governança.

A relação aqui proposta entre desempenho diferenciado e estratégia empresarial é recorrente na literatura: Nelson (1991, p. 61-62) chama a atenção para o fato de que as empresas apresentam desempenho diferenciado devido a escolhas distintas na elaboração da estratégia.

Williamson (1991B, p. 75) argumenta que o tema estratégia empresarial tem crescido em importância com o aumento da empresa multinacional, do comércio internacional e da concorrência. No argumento, também se relaciona estratégia ao poder no mercado da empresa. Contudo, se alerta para a importância da ênfase na racionalidade econômica.

Gwynne (2004, p. 243) afirma que, surpreendentemente, há pouca pesquisa sobre como empresas da América Latina lidam com estas novas pressões competitivas. Gwynne (2004, p. 253) propõe que uma das questões que deve ser estudada, está relacionada à definição das estratégias de negócios que permitiriam que as PMEs superarem com êxito o desmonte do Estado paternalista e sua própria falta de recursos.

Dunning (1995, p. 252 e 327) entende que as características específicas da firma em termos de comportamento estratégico, junto com características específicas de um setor, região e nação, são responsáveis por algumas das diferenças na configuração das vantagens competitivas.

Humphrey et al (1998, p. 11) expõem que, após anos estudando os problemas enfrentados por empresas de países em desenvolvimento no momento em que seus mercados se abrem à competição internacional, a resposta fundamental a este desafio está em uma alteração no foco estratégico (das empresas). As circunstâncias que as empresas dos países em desenvolvimento enfrentam são diversas daquelas dos países desenvolvidos, que contam com força de trabalho escolarizada, infra-estrutura moderna e mercados finais exigentes.

Easton e Araújo (1996, p. 184) expõem que uma das características mais recentes dos trabalhos no campo da estratégia é a tentativa de entender, de forma específica, o que impulsiona nas empresas seu desempenho econômico. Os pesquisadores em estratégia têm estado preocupados com as atividades (nas empresas) que geram valor, recursos, ativos, capacitações e competências, bem como as relações entre todos estes aspectos. A idéia é 
entender quais são os mecanismos dentro de uma empresa que criam riqueza. Também é lembrado que as empresas se encontram envolvidas em uma vasta teia de relacionamentos de relacionamentos inter-organizacionais, das quais elas retiram e para as quais elas exportam recursos.

Lane e Probert (2006, p. 35-36) criticam a literatura relacionada às redes de produção global, pois faltam considerações sobre a capacitação interna das empresas e como esta influencia a governança das redes.

Contudo, Camuffo et al (2005B, p. 4) notam que posições estratégicas distintas e configurações de atividades singulares não são nem do conhecimento prévio dos gestores, nem passíveis de serem obtidas facilmente. Sua identificação é um exercício complexo, que requer visão, conhecimento diferenciado e assunção de riscos. Na maior parte dos setores, poucas empresas possuem as capacitações, a determinação e a sorte de serem capazes de desenvolver estratégias que são diferentes do padrão. A maior parte das empresas briga por uma participação maior na demanda existente, se conformam com os limites setoriais e acabam por obedecer às regras competitivas do jogo. Com freqüência, elas se concentram na inovação incremental, no aperfeiçoamento de seu desempenho através da prática do benchmarkimg, na otimização de atividades isoladas e na imitação de rivais. Porém, à medida que o número de concorrentes cresce, a perspectiva de lucro e crescimento se reduzem, especialmente para os novos entrantes.

Lane e Probert (2006, p. 63) concluíram que, para entender o papel das empresas nas redes produtivas globais, é necessário estudar seu contexto doméstico, dar foco as suas estratégias competitivas e nos diferentes conjuntos de capacitações que foram desenvolvidos para perseguir estas estratégias.

\section{3 - Objetivos do estudo}

O foco do trabalho é o estudo de estratégias organizacionais para empresas conectadas às cadeias globais de valor para o acesso aos mercados no estrangeiro.

A exemplo do que propõe Palpacuer (2000, p. 354), o ponto de entrada da análise aqui desenvolvida são as estratégias organizacionais das empresas estudadas. Também Spener et al (2002, p. 8) argumentam favoravelmente à abordagem centrada na empresa, pois entre outras 
vantagens permite que a evolução das estratégias e comportamentos organizacionais das empresas seja documentada, além de sua identificação e caracterização. Contudo, Williamson (1985, p. 104) observa que não existe uma única unidade aceitável para o estudo de questões sobre a organização econômica. A escolha mais apropriada depende das questões que se deseja responder.

A idéia principal é que a conexão das empresas em GVCs pode se realizar de forma mais favorável ou menos favorável. A conexão mais favorável em GVCs possibilita à empresa governar a cadeia. Por sua vez, governança mais forte possibilita à empresa obter maior renda econômica. Analogamente, a conexão pela empresa a GVC de forma menos favorável, faz com que a empresa seja governada na cadeia e, portanto, obtenha menor renda econômica. Finalmente, a condição de maior ou menor governança na cadeia sofre influência da estratégia empresarial. Desta forma, condições mais favoráveis de governança seriam conseqüência de uma estratégia empresarial mais sofisticada. O mesmo raciocínio permite também supor que, estratégias menos sofisticadas trazem à empresa condições menos favoráveis de governança.

Das afirmações e relações apresentadas no item anterior, vêm a principal questão de pesquisa: quais as estratégias que foram e/ou poderiam ser desenvolvidas pelas empresas estudadas para que a conexão nas GVCs lhes possibilite maior renda econômica?

O argumento é que mercados com características diferentes, por exemplo, em termos de fragmentação e concentração dos compradores, trazem oportunidades distintas para as empresas em termos de condições mais favoráveis de governança e respectiva renda econômica. Desta forma, acredita-se que existam diversas possibilidades de estratégia para o aproveitamento destas oportunidades de obtenção de renda econômica superior.

Procura-se também responder as seguintes questões específicas ou secundárias:

- Quais são as características e circunstâncias dos mercados que influenciam a conexão nas GVCs, de forma que este evento gere maior renda econômica para as empresas estudadas? - Como as empresas em tela podem, através da diferenciação na estratégia, evitar a situação caracterizada pela ocorrência de atividade crescente e renda econômica decrescente? - Quais as características que deve ter a estratégia das empresas estudadas para que a governança das cadeias possa ser influenciada de forma a que lhes seja gerada maior renda econômica? 
- Como deveria ser abordada a inovação na estratégia das empresas estudadas?

- Dadas as características das GVCs nas quais as empresas estudadas estão inseridas, ou com possibilidade de inserção, como deve ser sua estratégia para que sejam maximizadas as possibilidades de aperfeiçoamento competitivo?

Os argumentos em que estas questões se baseiam são:

- As estratégias empresariais mais sofisticadas, com maior grau de inovação, tendem a possibilitar a inserção nas GVCs mais favorável das empresas nas cadeias (em relação às estratégias menos sofisticadas). Esta inserção mais favorável é verificada através da obtenção pela empresa de maior renda econômica. A razão pela qual isto ocorre é que estratégias mais sofisticadas possibilitam a inserção nas GVCs de forma mais favorável do que ocorreria com estratégias menos sofisticadas.

- As escolhas relacionadas à estratégia estão limitadas pelas relações de poder que existem nas GVCs, pela trajetória das empresas e pelas especificidades setoriais.

- O conceito de governança nas cadeias, do ponto de vista da tipologia, quanto às formas existentes, é um conceito útil.

- É verdadeiro que o tipo de governança existente nas cadeias nas quais as empresas podem se conectar, influencia a renda econômica obtida. Contudo, a teoria devotou menos atenção do que seria necessário à questão de como surge a governança da cadeia. Uma proposta deste trabalho é investigar este aspecto. O fundamento é que a governança das GVCs recebe influência das estratégias desenvolvidas pelas empresas.

- As características e circunstâncias dos mercados influenciam a renda econômica na inserção em GVCs.

- O aperfeiçoamento competitivo das empresas conectadas as GVCs não é fácil e nem ocorre naturalmente. A ocorrência, qualidade e intensidade do aperfeiçoamento competitivo dependem, entre outros fatores, de escolhas organizacionais, relacionadas à estratégia.

O quadro 1, exibido na seqüência, traz as variáveis, dependente e independente, relacionadas aos objetivos formulados. 
Quadro 1 - Variável independente, variável dependente e resultados

\begin{tabular}{|c|c|c|}
\hline $\begin{array}{c}\text { VARIÁVEL } \\
\text { INDEPENDENTE }\end{array}$ & $\begin{array}{c}\text { VARIÁVEL } \\
\text { DEPENDENTE }\end{array}$ & RESULTADOS \\
\hline $\begin{array}{c}\text { Existência de limitações para a } \\
\text { obtenção de maior renda } \\
\text { econômica nas GVCs das quais as } \\
\text { empresas estudadas participam ou } \\
\text { podem vir a participar. }\end{array}$ & $\begin{array}{c}\text { Sofisticação das estratégias } \\
\text { desenvolvidas pelas empresas } \\
\text { estudadas e sua respectiva forma } \\
\text { de inserção }\end{array}$ & $\begin{array}{c}\text { Renda econômica obtida ou } \\
\text { esperada pela empresas } \\
\text { estudadas. }\end{array}$ \\
\hline
\end{tabular}

A idéia central é que há uma relação entre os eventos sofisticação da estratégia desenvolvida e renda econômica. A expectativa é que quanto mais sofisticada for a estratégia, maior será a renda econômica obtido pela empresa. A razão desta relação está no seguinte: a maior sofisticação da estratégia aumenta as chances da empresa desenvolver vantagens competitivas classificadas como de alto nível. São estas vantagens competitivas de alto nível que possibilitam a inserção de maneira mais favorável das empresas nas GVCs. Este tipo de vantagem competitiva não se baseia em fatores como mão-de-obra barata ou localização privilegiada devido a fatores naturais. A expectativa é que as estratégias mais sofisticadas aumentem as chances de obtenção de maior renda econômica, pois é facilitada a ocorrência de fatores como marcas, design avançado e inovações. Não é fácil e nem rápido desenvolver estes fatores. São necessárias competências relacionadas à gestão para desenvolvê-las. Poucas empresas desenvolvem estas competências. Uma vez que estratégias sofisticadas só estão ao alcance de poucas empresas, aquelas que logram desenvolvê-las e implementá-las obtêm maior renda econômica. O desenvolvimento destes fatores se transforma em barreiras à entrada de concorrentes.

Outro componente da hipótese é que o aperfeiçoamento competitivo traz maior renda econômica.

A observação da ilustração 1, que segue, auxilia na compreensão das relações e argumentos apresentados. 


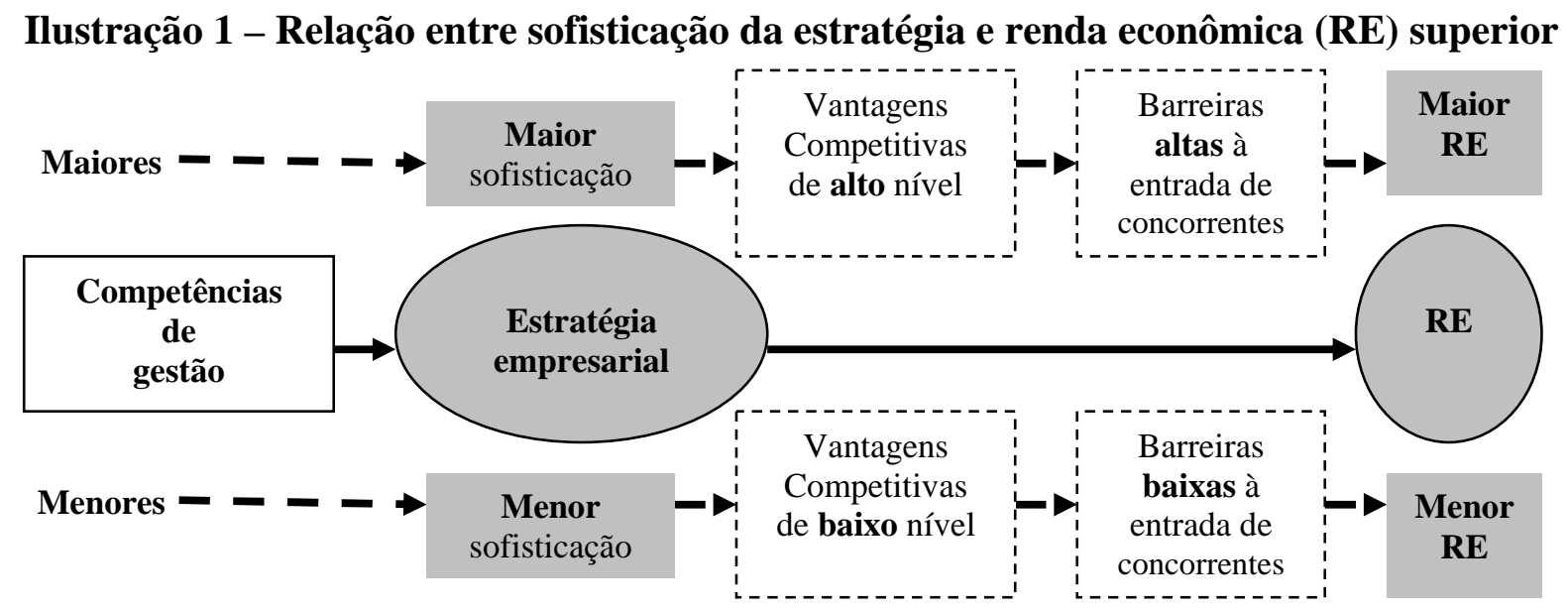

Portanto, decorre que a conexão em GVCs de forma mais favorável ou superior é uma conseqüência de uma estratégia empresarial sofisticada. É possível que as empresas aprendam a competir de forma mais sofisticada ao se conectarem as GVCs, mas o argumento aqui é que o grau em que isto ocorre é também dependente do grau de sofisticação da estratégia empresarial.

Contudo, há fatores que, na teoria sobre cadeias, têm sido considerados como fora do controle direto da empresa, que neste trabalho compõem a variável classificada como independente. Estes fatores influenciam a relação entre sofisticação da estratégia e nível de renda econômica que pode ser obtido pela empresa. Aqui, estes fatores são chamados de limitações à obtenção de renda econômica superior que podem existir. As limitações tratadas aqui são: (1) As relacionadas ao poder existente nas GVCs, a chamada governança da cadeia. (2) Aquelas relacionadas à trajetória das empresas. (3) As relacionadas às características do setor de atuação.

A ilustração 2, que segue, apresenta de forma esquemática a influência das limitações à obtenção de renda econômica. 
Ilustração 2 - Limitações à obtenção de renda econômica (RE) superior

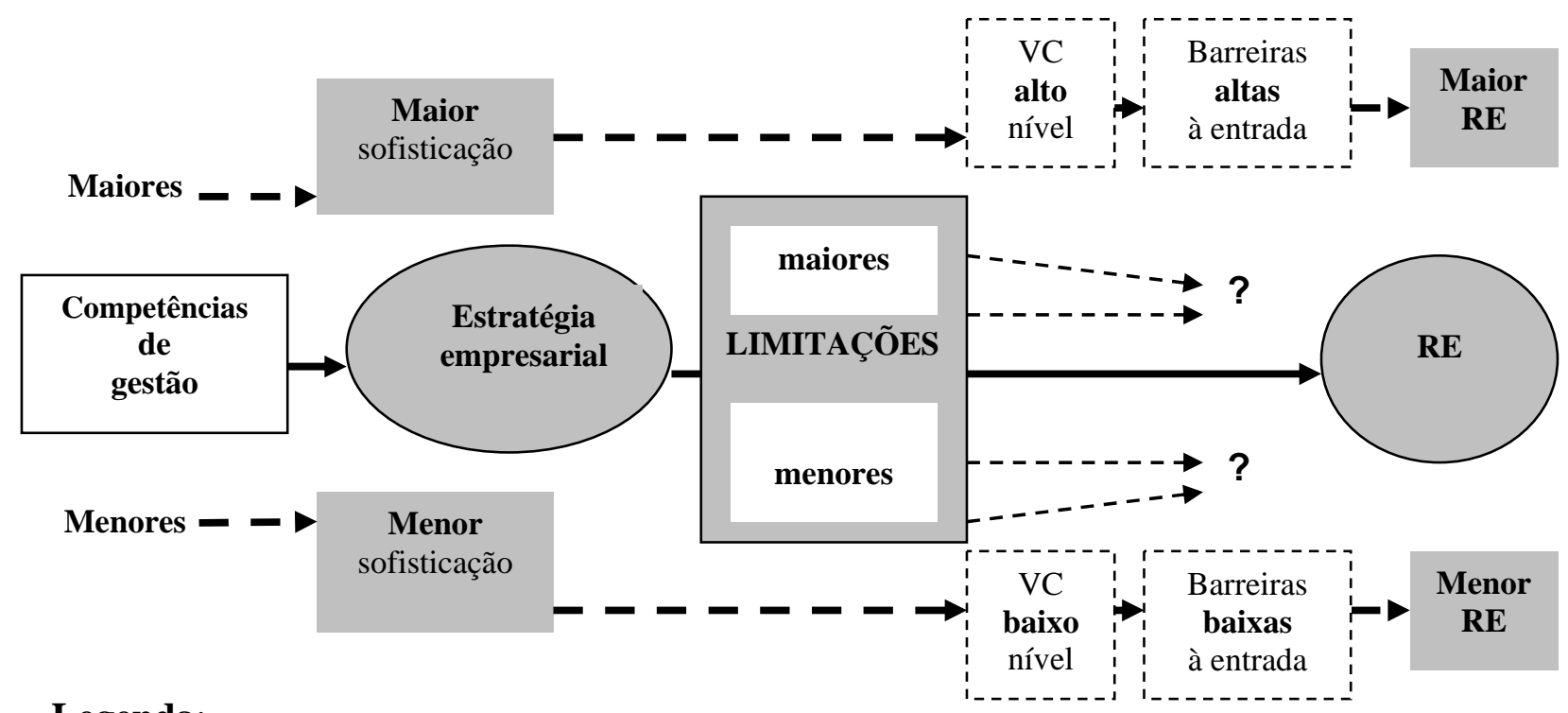

\section{Legenda:}

RE: Possibilidade de obtenção de renda econômica superior

VC: Vantagem competitiva

No entanto, no caso da governança, um alerta precisa ser feito: é possível que estratégias mais sofisticadas influenciem a governança da cadeia. Portanto, a relação é que estratégias mais sofisticadas renderiam condições mais favoráveis de governança, que por sua vez trariam renda econômica superior. As estratégias menos sofisticadas seriam menos capazes de influenciar favoravelmente a governança das cadeias. Este aspecto está refletido na ilustração 3 apresentada a seguir. 


\section{Ilustração 3 - Limitações à obtenção de renda econômica superior: estratégia} empresarial influenciando governança

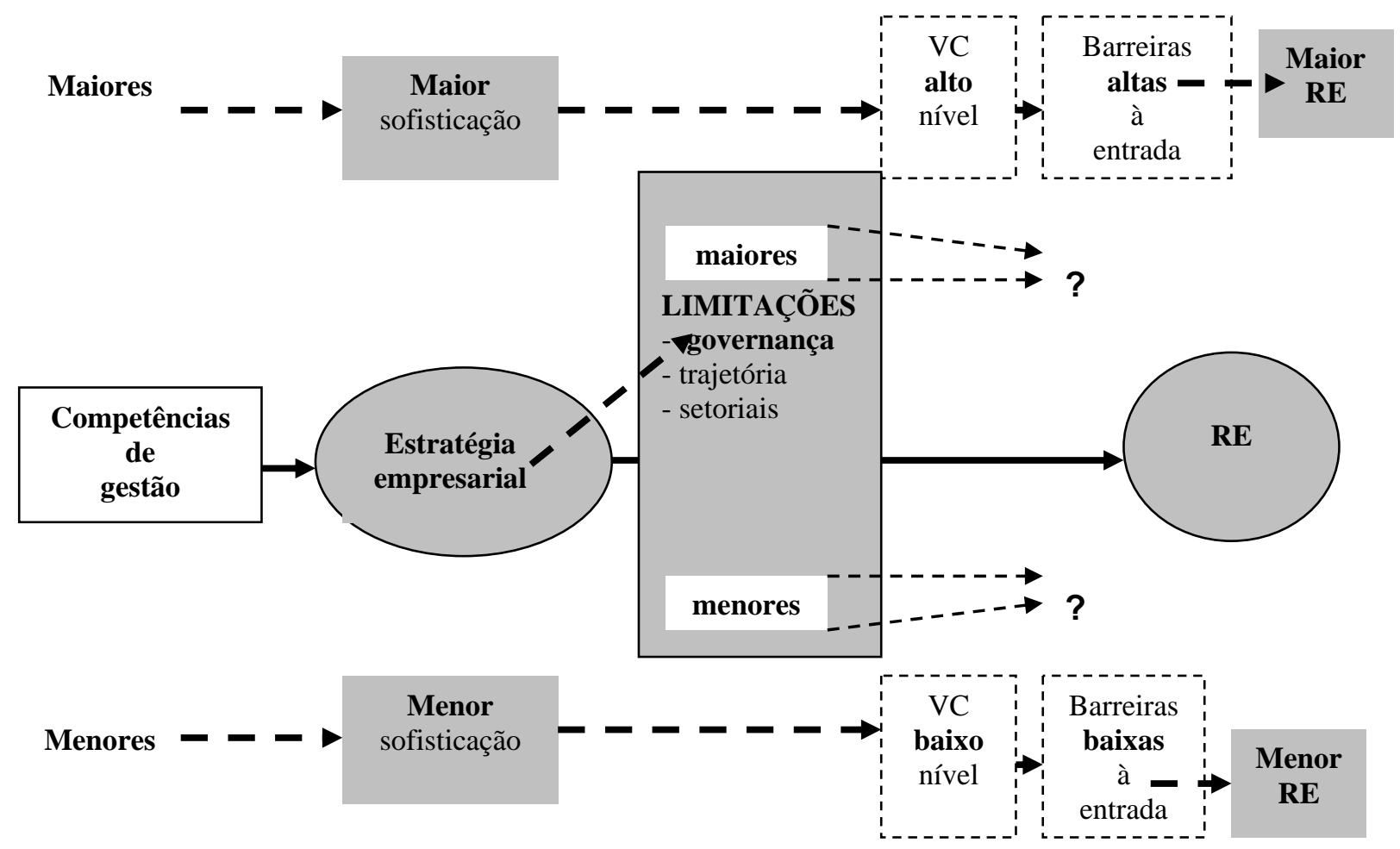

\section{Legenda:}

RE: Possibilidade de obtenção de renda econômica superior

VC: Vantagem competitiva

Portanto, o que se argumenta aqui é que, embora a variável governança tenha sido inicialmente tratada como independente, é possível que ela sofra influência da estratégia empresarial. A relação proposta é que estratégias mais sofisticadas contam com maiores possibilidades de levar a empresa a uma posição de maior poder na cadeia, o que também pode ser classificada de inserção mais favorável ou superior. Por sua vez, as estratégias menos sofisticadas mais frequentemente levarão as empresas a posições de menor poder nas GVCs. Empresas que governam as cadeias têm chances maiores de obter renda econômica superior. Empresas que são governadas nas relações das cadeias têm menores chances de obtenção de renda econômica superior.

Desta forma, ao trazer esta relação para a ilustração 3, uma empresa em uma posição de maior poder na cadeia enfrenta limitações menores à obtenção de renda econômica superior. Analogamente, uma posição de menor poder faz com que a empresa enfrente maiores limitações na obtenção de renda econômica superior. 
Para responder às questões de pesquisa colocadas - principal e secundárias - as empresas estudadas são avaliadas com indicadores, quanto a sua estratégia empresarial e possibilidades e limitações à obtenção de renda econômica superior. Com base nesta avaliação, as empresas são classificadas em oito categorias. Esta classificação é inserida no modelo apresentado na ilustração 3. Os indicadores e as propostas de classificação dos casos podem ser encontrados no capítulo 4, item 4.3 do presente trabalho.

\section{4 - Delimitação da pesquisa}

A primeira observação que precisa ser feita em termos de limites diz respeito ao perfil das empresas estudadas. Aqui foi feita uma opção pelo estudo de empresas de países em desenvolvimento, ou seja, há a premissa de que a obtenção de rendas superiores por estas empresas segue uma rota diferente das empresas dos países desenvolvidos.

A segunda nota está relacionada às áreas ou atividades de uma empresa. Evidentemente que aspectos operacionais podem constranger ou potencializar os efeitos de uma estratégia. Embora se reconheça este aspecto, aqui só se tratou da estratégia empresarial e da capacitação para a obtenção de rendas superiores em um ambiente competitivo.

A terceira consideração quanto aos limites da pesquisa está ligada ao fato de que a linha de investigação das GVCs trata com bastante intensidade o aperfeiçoamento competitivo e obtenção de competitividade através dos clusters, no Brasil freqüentemente chamado de arranjo produtivo local (APLs). Não é o caso deste trabalho.

Ainda sobre os limites da pesquisa, os estudiosos do tema estratégia poderão observar que este é tratado de maneira superficial. De fato, esta é uma pesquisa sobre GVCs e respectiva governança em serviços associados a TI, que inclui o tema estratégia empresarial neste contexto. Não se trata de um trabalho de estratégia que passa pelas GVCs.

Cabe uma quarta nota, associada à estrutura organizacional. Embora o trabalho trate da governança nas GVCs, aqui não se argumenta que esta estrutura seja mais (ou menos) eficaz do que uma estrutura verticalizada. Apenas é notado que, a partir do reconhecimento da emergência das GVCs, é relevante investigá-las. 
É importante explicitar que este é um trabalho de Administração, não sendo portanto de tecnologia TI ou software. Desta forma, se há alguma imprecisão nas definições técnicas que são necessárias, em parte, pode ser creditada a este direcionamento.

Finalmente, na pesquisa de campo, evidentemente, se passou próximo das redes locais as quais estão conectadas no Brasil as empresas estudadas. Em muitos casos, as características dessas redes são semelhantes às das cadeias globais em que as empresas estão conectadas. Contudo, mesmo que exista algum comentário sobre as redes locais no texto, estas não são objeto de estudo desta pesquisa. Os comentários, que porventura existirem, tem como objetivo esclarecer as circunstâncias da conexão das empresas estudadas as GVCs. 


\section{Capítulo 2 - REVISÃO DA LITERATURA}

\section{1 - Cadeias Globais de Valor}

Kaplinsky e Morris (2003, p. 4-6) afirmam que o conceito cadeia de valor descreve o escopo completo de atividades que são necessárias para criar um produto (bem ou serviço), ao longo das diferentes fases da produção, entrega aos clientes finais e destino após sua utilização. Na prática, contudo, as cadeias de valor assumem complexidade muito maior. Além de sua maior complexidade, os fornecedores de uma cadeia de valor podem estar envolvidos em várias delas simultaneamente.

Rugman e D’Cruz (2000, p. 70-72) notam a relação entre competitividade e cadeias de valor: o ambiente competitivo da atualidade penaliza com rigor cada vez maior as empresas que operam com estruturas rígidas. A rigidez limita interação, comunicação, aprendizado, inovação, e a capacidade de adaptação rápida. A solução representada pelas transações de mercado também traz inadequações: as redes de valor complexas exigem investimento em ativos valiosos ${ }^{4}$, que são difíceis de proteger através da contratação pelo mercado.

Também Kaplinsky e Morris (2003, p. 25) alertam para três importantes componentes das cadeias de valor, que as transformam em uma ferramenta analítica: (1) As cadeias de valor são repositórios de renda e estas rendas são dinâmicas. (2) As cadeias de valor com funcionamento eficaz envolvem algum grau de governança. (3) Há diferentes tipos de cadeias de valor.

Sturgeon (2000, p. 6) propõe ainda que o termo cadeia de valor seja usado para apresentar uma seqüência de atividades. Esta seqüência de atividades teria como base um produto e em um dado momento no tempo funciona em uma constelação mais ampla de atividades e configurações dinâmicas incorporadas em uma rede produtiva. Uma cadeia de valor pode ser conceituada como um subconjunto da rede produtiva. A cadeia de valor seria uma parte dentro de um conjunto de atividades mais complexo e dinâmico compreendidos pela rede.

\footnotetext{
${ }^{4} \mathrm{O}$ termo proprietary foi traduzido livremente como valioso.
} 
A abordagem da cadeia de valor também desempenha um papel relevante ao garantir que a análise compreenda todo o ciclo produtivo, de forma a incluir a conexão aos mercados finais e suas características quanto à governança. As formas específicas pelas quais as empresas se conectam aos mercados finais, afetam suas possibilidades de aperfeiçoamento competitivo. (KAPLINSKY; MORRIS, 2003, p. 9-13).

Gereffi et al (1994, p. 1) apontam as características da produção em cadeias de valor: especialização flexível, baixa dedicação dos equipamentos, alta diferenciação de produtos e lotes pequenos. Também Gereffi (1996, p. 437) explica que a perspectiva das GVCs amplia a noção de campo organizacional, de forma a incluir redes estratégicas de atores econômicos inovadores e designers, fornecedores de insumos, comerciantes, financistas, atacadistas e varejistas - que provêem conjuntos específicos de produtos na economia global.

Palpacuer (2000, p. 390) conclui que a discussão das alterações na estratégia organizacional das empresas foi útil para trazer à baila a emergência das formas organizacionais que se caracterizam pelos altos níveis de flexibilidade e reatividade às mudanças de mercado.

De acordo com Sturgeon (2000, p. 7) outra dimensão crucial das cadeias de valor e redes produtivas é a escala espacial. Gereffi (1999) diferencia seu conceito de cadeia produtiva global do conceito apresentado por Porter (1990, p. 32) chamado por este último de sistema de valor, em parte por incorporar a dimensão internacional de forma explícita.

Para Whitley (1996, p. 411 e 414-416), o foco das cadeias globais de valor é a coordenação de atividades econômicas através de fronteiras. A abordagem da cadeia global de valor tem foco nas ações de empresas específicas e é útil para o estudo da organização econômica. Sua característica fundamental parece ser o estabelecimento de um sistema de coordenação global, que organiza a produção e as trocas em diferentes locais de acordo com suas vantagens competitivas em um momento específico.

Dolan e Humphrey (2000, p. 148) notam que o conceito da cadeia global de valor é uma das abordagens para relações entre empresas. Este conceito está baseado na idéia de que o design, a produção e o marketing dos produtos envolvem uma cadeia de atividades distribuída entre diferentes empresas. 
Kaplinsky (2005, p. 113) apresenta a idéia na qual a cadeia global de valor é configura uma forma de conexão aos mercados finais.

Na verdade, argumenta Sturgeon (2000, p. 9), que ao invés de se relacionar os termos a empresas, setores ou localidades, esta relação deve ser feita em relação às atividades desenvolvidas pelas empresas. O quadro 2 que segue apresenta os diversos atores das cadeias de valor e redes produtivas.

Quadro 2 - Atores das cadeias de valor e redes produtivas

\begin{tabular}{|c|c|c|c|}
\hline ATOR & ESCOPO DE ATIVIDADE & OUTROS NOMES & $\begin{array}{l}\text { EXEMPLOS } \\
\text { EMPRESARIAIS }\end{array}$ \\
\hline $\begin{array}{l}\text { 1) Empresa } \\
\text { integrada }\end{array}$ & $\begin{array}{l}\text { - Estratégia e definição de produto } \\
\text { - Design } \\
\text { - Fabricação } \\
\text { - Montagem } \\
\text { - Fabricação de componentes } \\
\text { - Marketing, vendas e distribuição. }\end{array}$ & $\begin{array}{l}\text { - Corporação moderna } \\
\text { - Empresa envelhecida }\end{array}$ & $\begin{array}{l}\text { - Antiga Ford e } \\
\text { IBM }\end{array}$ \\
\hline $\begin{array}{l}\text { 2) Empresa } \\
\text { líder }\end{array}$ & $\begin{array}{l}\text { - Estratégia, definição de e design de } \\
\text { produto } \\
\text { - Vendas e marketing ao usuário final }\end{array}$ & $\begin{array}{l}\text { - Empresa de marca } \\
\text { - OEM } \\
\text { - Empresa âncora }\end{array}$ & $\begin{array}{l}\text { - Dell } \\
\text { - Gap } \\
\text { - Smart / Daimler } \\
\text { - Ford e IBM na } \\
\text { atualidade }\end{array}$ \\
\hline $\begin{array}{l}\text { 3) Fornecedor } \\
\text { turn-key }\end{array}$ & $\begin{array}{l}\text { - Peças e serviços complexos } \\
\text { - Processos de P\&D }\end{array}$ & $\begin{array}{l}\text { - Fornecedor de sistemas } \\
\text { - Fornecedor OEM } \\
\text { - Fornecedor de } 1^{\circ} \text { nível } \\
\text { - Contratado } \\
\text { - Fornecedor total (full-package) }\end{array}$ & $\begin{array}{l}\text { - Dana, DELPHI } \\
\text { - Ryder Logistics }\end{array}$ \\
\hline 4) Varejista & $\begin{array}{l}\text { - Vendas } \\
\text { - Marketing } \\
\text { - Embalagens para agregação de } \\
\text { valor e integração de sistemas }\end{array}$ & $\begin{array}{l}\text { - Comercializador } \\
\text { - Distribuidor } \\
\text { - Revendedor } \\
\text { - Revendedor de valor } \\
\text { adicionado }(V A R)\end{array}$ & $\begin{array}{l}\text { - Amazon.com } \\
\text { - Sears }\end{array}$ \\
\hline $\begin{array}{l}\text { 5) Fornecedor } \\
\text { de } \\
\text { componentes }\end{array}$ & - Componentes específicos & $\begin{array}{l}\text { - Fornecedor de baixo nível } \\
\text { - Fornecedor especializado } \\
\text { - Sub-contratado } \\
\text { - Produtor de produto não } \\
\text { diferenciado (commodity) }\end{array}$ & $\begin{array}{l}\text { - Intel, Microsoft } \\
\text { - BF Goodrich }\end{array}$ \\
\hline
\end{tabular}

FONTE: Adaptado de STURGEON, 2000, p. 10.

Schmitz e Knorringa (1999, p. 6) reconhecem que vêm de uma preocupação com empresas e seus agrupamentos. Com o objetivo de entender a sua competitividade e trajetórias de 
aperfeiçoamento competitivo, é necessário compreender o sistema mundial que inclui as cadeias de valor.

Kaplinsky (2000, p. 128-129) aponta que a análise da cadeia de valor difere dos estudos setoriais convencionais porque dá foco nos determinantes da distribuição de renda. Somente através de uma visão total da cadeia da cadeia de valor, é possível identificar os elos das cadeias ou segmentos dos mercados que se caracterizam por rendas altas ou crescentes. A análise da cadeia de valor torna possível acompanhar veios específicos de atividades de alta renda, os quais não seriam notados através da análise setorial. A possibilidade de identificação das atividades de alta renda ao longo da cadeia de valor adicionado é fundamental para o entendimento da apropriação, em termos globais, dos retornos da produção.

Humphrey (2003, p. 10) menciona que a contribuição da abordagem GVC está em três pontos principais: (1) Coordenação dos sistemas dispersos de produção e distribuição Além da coordenação através dos mecanismos de mercado e da integração vertical, os mercados globais são coordenados de forma crescente pela formação de redes de empresas. Isto algumas vezes envolve a coordenação complexa de atividades (design de produtos, especificação de processos e sincronização de atividades) entre empresas sem ligações societárias. (2) Reconhecimento e ênfase do papel desempenhado pelas empresas não manufatureiras - designers, varejistas e aqueles que constroem marcas - na formação dos sistemas de produção e distribuição globalmente dispersos. (3) Considerações acerca das diferentes formas através das quais o aperfeiçoamento competitivo das empresas conectadas às GVCs ocorre.

Steinfeld (2002, p. 6-7) explica que, ao passo que, no passado as cadeias de valor eram coordenadas internamente na empresa verticalmente integrada, porém, na atualidade existem oportunidades para a coordenação externa destas redes, além dos limites de muitas empresas. Pelo menos em alguns setores, as empresas líderes desenvolvem atividades fundamentais da cadeia de valor. Seja através do design, das marcas ou da produção, há oportunidade de se organizar o resto da cadeia com eficácia, sem necessidade de possuí-la. As atividades de alto risco e baixos retornos podem ser transferidas a terceiros. A empresa líder pode desta forma buscar a especialização de acordo com suas próprias fontes de vantagem competitiva. A influência pode ser exercida através de produtos e processos patenteados e designs exclusivos. 
É notado que estas interações entre as empresas têm o perfil que é mais tradicionalmente associado com o comportamento dentro de uma única empresa. As implicações destes eventos para as estruturas empresariais, embora ainda não totalmente claras, são potencialmente profundas. Primeiro, as empresas têm incentivos crescentes para se especializar e expandir ativos intangíveis não transferíveis. Nas tarefas não especializadas, há risco permanente de transferência para outra empresa que a desempenhe por menor valor. Portanto, o risco de se competir só em preço é excessivamente alto.

Humphrey e Memedovic (2003, vii) argumentam que, no setor automobilístico, embora haja uma crescente preferência pela utilização dos mesmos fornecedores em diferentes locais, existem oportunidades de fornecimento em um segundo nível para as empresas de países em desenvolvimento. Neste nível, não haveria necessidade de um alcance global.

Gibbon e Ponte (2005, p. 78) notam que o aspecto principal das GVCs é a ligação contratual de empresas formalmente independentes. Esta ligação pode ocorrer de várias formas; seja como o resultado da terceirização de funções anteriormente integradas de forma vertical por empresas multinacionais, seja através da subordinação de fornecedores previamente conectados através de transações de mercado.

Como afirmam Schmitz e Knorringa (1999, p.3), há controvérsias com relação aos intermediários. As interpretações da atuação dos compradores variam, indo de exploradores a impulsionadores dos produtores. No entanto, a questão não é se os intermediários bloqueiam ou promovem o desenvolvimento econômico, mas sob que circunstâncias o papel desempenhado é positivo ou negativo. Conforme nota Knutsen (2004, p. 545), há exemplos que mostram que os compradores globais desempenham papel positivo e também o contrário. As cadeias globais de valor dominadas pelos compradores tiveram papel favorável ao processo de industrialização em Taiwan, Coréia e Hong Kong, i.e., a primeira geração das economias asiáticas recentemente industrializadas.

Humphrey e Schmitz (2000, p. 10) reconhecem a importância do trabalho de Gereffi neste campo, mas apontam que o termo principal utilizado, a cadeia global de mercadorias, pode ser enganoso. A análise da cadeia global de valor também é relevante para a comercialização de produtos diferenciados, e não somente para aqueles padronizados que são produzidos em volumes altos. 
Regnier (2004, p. 160-161) argumenta que as empresas transnacionais (TNCs) são atores da maior importância nas cadeias globais de valor. Contudo, as empresas menores dos países em desenvolvimento não estão diretamente ligadas às TNCs e estão em desvantagem competitiva em relação às grandes empresas locais nos mercados nacionais. Nos países desenvolvidos, o quadro seria distinto, pois a maioria das empresas classificadas como pequenas atuaria de forma complementar, além de serem competitivas, em relação às TNCs e grandes empresas locais. Nestes países as empresas menores mais capacitadas obteriam acesso mais fácil as GVCs, devido às várias formas de apoio das TNCs.

Há também estratégias de curto prazo que as empresas podem adotar, como destaca Neidik (2004, p. 297), ao analisar as empresas de confecção da Turquia. Neste sentido, muitas empresas apostaram em transferir algumas das atividades para o exterior, o que pode ajudar na redução de custos.

Dedrick e Kraemer (1998, p. v-vi e p. 278) concluíram no estudo sobre o setor de informática que, alguns países em desenvolvimento são participantes ativos do chamado sistema global de produção. A primeira implicação da experiência das empresas do Leste asiático é a importância para as empresas de sua integração no sistema global.

Humphrey e Schmitz (2000, p.1) argumentam que o fato de operar em cadeias globais do tipo quasi-hierárquico ajuda produtores globais a embarcarem em um rápido aperfeiçoamento de produtos e processos. Contudo, é difícil progredir para as funções de marketing e design da cadeia. Esta limitação seria menos provável nas cadeias não hierárquicas, nas quais as relações são de mercado ou baseadas em redes. Nestes casos, entretanto, o aperfeiçoamento competitivo não ocorre sem um investimento substancial pelos produtores locais e apoio de outras instituições.

Hunter (2005, p. 279) nota que pouco se sabe em cadeias globais de valor que não estão claramente definidas. Um dos exemplos são redes para novos produtos, resultantes da inovação por empreendedores que buscam estabelecer um mercado ao invés de servir um que já existe. É necessário investigar como estas redes se modificam ao longo do tempo, à medida que se tornam mais rígidas e estabelecidas. A inovação, em um sentido schumpeteriano, não 
está limitada à produção ou inovação em serviços. Pode ser uma nova combinação de fatores existentes.

Conforme Humphrey e Schmitz (2000, p. 25-26), a escassez de casos que exemplifiquem as relações do tipo rede entre empresas de países emergentes e aqueles que compram seus produtos pode refletir o fato que este tipo de cadeia é raramente encontrado. A conclusão é que empresas de países emergentes obtêm competências através da inclusão em cadeias globais de valor. Contudo, a entrada em cadeias de valor cuja governança é caracterizada como tipo rede exige um investimento no nível da firma em aperfeiçoamento competitivo.

Sturgeon (2003, p. 4) ao estudar a terceirização em produtos eletrônicos no período 19922002, apresenta o conceito de cadeia de valor modular: trata-se de um conceito surgido nas décadas de 1980 e 1990 a partir do desmonte das estruturas empresariais verticalmente integradas. Ocorreu também a agregação horizontal de atividades ao redor de conjuntos de funções intimamente ligadas da cadeia de valor. A partir desta mudança, dois grandes conjuntos de firmas podem ser identificados: (1) Firmas líderes. Tem foco em desenvolvimento de produto, atividades de marketing e distribuição a algumas vezes em algum estágio final da produção. (2) Fornecedores de pacotes prontos (turn-key). Tem foco na comercialização, como prestação de serviços, das atividades que as empresas líderes decidiram terceirizar.

Sturgeon (2003, p. 9) também indica que o que é importante na geografia dos fornecedores globais é que eles estão firmemente ligados a regiões com custos operacionais baixos e também a regiões que contam com altos custos operacionais. Localidades como o Vale do Silício ou Detroit mantém atividades que apóiam as interações entre as empresas líderes e seus fornecedores, que resistem à codificação. Estas localidades são também utilizadas para a produção de produtos de alto valor e/ou de baixo volume.

Dedrick e Kraemer (1998, p. 225-230) apresentam de forma esquemática as diferenças nas ligações com as redes produtivas globais do setor de informática de vários países da Ásia. Em software, a proximidade aos usuários principais é crítica para o seu desenvolvimento. Nem sempre estes usuários sofisticados estão em mercados dos países desenvolvidos, pois países como Hong Kong, Israel e Nova Zelândia contam com este perfil de comprador em setores 
como atividade bancária, agricultura e defesa. As empresas locais desenvolveram produtos para estes setores no mercado doméstico e posteriormente os comercializaram no exterior.

Kaplinsky e Morris (2003, p. 44) afirmam que a abordagem das alavancas de poder na dinâmica das redes de valor auxilia no entendimento de como os resultados são distribuídos. Primeiro, o foco na compreensão dos diferentes componentes da renda torna possível a identificação das atividades na cadeia que tornam sustentáveis as rendas superiores. Segundo, se utilizado de forma apropriada, o foco nas barreiras à entrada na abordagem da cadeia de valor permite que se compreenda a dinâmica da distribuição destes resultados. Aqui, é possível a identificação de atividades que estão sujeitas à competição crescente (por exemplo, a transformação física de insumos em produtos) e daquelas que provavelmente serão sustentáveis ou possibilitarão barreiras à entrada altas no futuro (por exemplo, design, gestão de marcas). Terceiro, o foco da abordagem da cadeia de valor nas relações de poder explica de quem são os comportamentos que devem ser alterados para que diferentes resultados venham a emergir. Os fatores utilizados na produção não contribuem de forma individual: eles estão agrupados em instituições, que desenvolvem ligações com o passado, formas tácitas de conhecimento e capacitação tecnológica.

\section{2 - Aperfeiçoamento competitivo, competitividade e capacitação}

De acordo com Gibbon e Ponte (2005, p. 87-88) o termo aperfeiçoamento competitivo (uprading) tem sido utilizado na literatura, de forma geral, para enfatizar a possibilidade de movimentação, pelas empresas dos países em desenvolvimento, para funções mais rentáveis da cadeia de valor. Esta movimentação pode ocorrer através de funções que possibilitam a obtenção de mais renda ou através do desenvolvimento de produtos com maior valor adicionado.

O aperfeiçoamento competitivo de alto nível é colocado como um paradigma pós fordista. No chamado modo de produção fordista, o aperfeiçoamento competitivo ocorreria através do acréscimo de capital físico e inovação tecnológica, que levariam as empresas à obtenção de economias de escala, bem como melhoramentos nos produtos e nos processos produtivos. No modo de produção pós fordista, o aperfeiçoamento competitivo ocorreria principalmente através da obtenção de níveis mais altos de flexibilidade e da adição de novas capacitações e 
habilidades relacionadas aos recursos humanos e em especial aquelas relacionadas marketing e ao design. Este aperfeiçoamento aconteceria através das redes de empresas e do aprendizado organizacional relacionado. O pós fordismo e o modelo de aperfeiçoamento competitivo associado a ele são apresentados como o caminho de alto nível para a flexibilidade tecnológica, produção de alto valor, novos níveis de prestação de serviços (o que inclui marcas) e uma experiência dos funcionários mais interessante. O fordismo, em contrapartida, é identificado como um caminho de baixo nível, que implica em rigidez tecnológica, produtos pouco diferenciados (commodities), prestação de serviços em níveis mínimos, baixa capacitação da força de trabalho.

Gibbon e Ponte (2005, p. 138) também propõem o uso do termo marginalização para se referir ao oposto de aperfeiçoamento competitivo. O termo marginalização é utilizado para fazer referência à situação na qual a empresa é relegada para funções de menor remuneração ou segmentos de mercado com barreiras à entrada mais baixas. Um caso extremo seria a exclusão, termo usado para se referir à incapacidade de entrar nas GVCs, bem como à expulsão das empresas de uma cadeia.

Buckley et al (1988, p. 176-180 e 191-192) concordam com a definição de competitividade que argumenta que uma empresa é competitiva se pode produzir produtos e serviços de qualidade superior a custos mais baixos que seus competidores locais e internacionais. Também se relaciona competitividade e renda, ao apresentar a definição de que a competitividade é a capacidade de produzir renda para seus acionistas no longo prazo. Esta definição sugere que a medida da competitividade empresarial deve incluir indicadores de rentabilidade e qualitativos não relacionados a preço, como, por exemplo, qualidade. Como medida do desempenho da competitividade empresarial, sugere-se o seguinte conjunto de métricas: (1) Participação de mercado na exportação. (2) Dependência de exportações. (3) Crescimento das exportações. Um dos conceitos colocados é a da competitividade potencial e a transformação do potencial competitivo em desempenho competitivo. Esta seria uma tarefa dos gestores. Um dos aspectos desta tarefa seria o compromisso com os negócios internacionais.

No entanto, a medição da competitividade é um assunto controverso. Lall (2001, p. 15191520) concluiu que o ceticismo com relação à quantificação da competitividade parece justificado. Para serem aceitáveis do ponto de vista analítico, os esforços relacionados a 
estudar a competitividade deveriam ser mais limitados em termos de cobertura, de forma a abranger no máximo setores (ao invés de economias) e utilizando um número menor de variáveis críticas. O fenômeno competitividade é complexo demais para permitir medições fáceis.

Barney (1991, p. 102-103) propõe que se pode afirmar que uma empresa tem uma vantagem competitiva quando desenvolve uma estratégia de criação de valor que não é implementada simultaneamente por nenhum de seus concorrentes atuais ou potenciais. O conceito de sustentação da vantagem competitiva não está relacionado ao tempo, mas sim à possibilidade de duplicação da vantagem pela concorrência. Foss (2007, p. 33) também debate o processo de criação de vantagem competitiva. A vantagem competitiva, e portanto o desempenho diferenciado, seriam originados nas capacitações inimitáveis da empresa.

Kaplinsky e Morris (2003, p. 24 e p. 37) destacam a importância do aperfeiçoamento competitivo: a participação nos mercados globais com crescimento sustentado de renda exige que a empresa tenha capacidade de aprender e se aperfeiçoar competitivamente.

A diferença entre o caminho chamado de alto nível para a competitividade e aquele chamado de baixo nível é apresentada. O que explicaria a diferença entre estes dois caminhos seria fundamentalmente a capacidade de inovar e garantir progresso contínuo no desenvolvimento de produtos e processos. Contudo, a inovação por si pode não ser o suficiente. Se a taxa de inovação de uma empresa for mais baixa que aquela dos seus concorrentes, o resultado pode ser declínio no valor agregado e na participação de mercado. Portanto, a inovação deve ser avaliada em termos relativos - quão rápido em relação à concorrência - e este processo recebe o nome de aperfeiçoamento competitivo. O conceito de aperfeiçoamento competitivo, que é diferente de inovação, reconhece explicitamente os méritos relativos e a existência de renda.

Gereffi (1999, p. 51) introduziu a idéia do processo de aperfeiçoamento industrial, no sentido de aprendizado organizacional, para melhorar a posição de firmas ou nações em redes internacionais de comércio. Trata-se da capacidade de uma empresa ou de uma economia de se movimentar para um nicho econômico mais rentável e/ou mais sofisticado tecnologicamente, mais intensivo em capital e competências. 
Kaplinsky e Morris (2003, p. 37-38) tentam então responder como se pode saber que uma empresa administrou no sentido de aperfeiçoar competitivamente suas atividades. Haveria duas linhas de pensamento: (1) Aquela que traz o conceito de competências fundamentais; e (2) Aquela que traz o conceito de capacitação dinâmica.

Ambastha e Momaya (2004, p. 46-50) afirmam que a competitividade vem de um esforço integrado nas diversas funções (da empresa) e, portanto, possui ligação próxima com o processo estratégico. A falha em compreender como a competitividade se integra à estratégia, pode ser uma causa fundamental da baixa competitividade das empresas na Índia.

Maskell e Malmberg (1999, p. 179-181) concluíram que a competitividade no longo prazo está relacionada à habilidade das empresas de continuamente aperfeiçoar sua base de conhecimento e seu desempenho. Trata-se de, não somente, focar na obtenção de eficiência estática através da identificação e exploração de recursos de baixo custo e economias de escala. É inerente a esta conclusão que o conhecimento é um ativo fundamental para as empresas competitivas, bem como o aprendizado que seria um processo da maior importância. Portanto, o caráter dos processos de aprendizado implica que a história tem um peso. Para lidar com o caráter incerto e incremental dos processos de aprendizado, as empresas desenvolvem várias rotinas e procedimentos. O sucesso estimula a durabilidade destas rotinas, o que leva ao estabelecimento de trajetórias de aprendizado que são dependentes do passado.

Rugman e D’Cruz (2000, p. 80-81) destacam que o aprendizado organizacional desempenha papel fundamental na organização das transações econômicas e na competitividade. A competitividade empresarial estaria se tornando menos uma questão de exploração de vantagens de porte e poder de mercado e mais o aproveitamento da flexibilidade e adaptabilidade da rede. Estes traços, quando combinados com competitividade nas tecnologias líderes, podem ser maneiras poderosas de obtenção de competitividade empresarial.

Kaplinsky (2005, p. 89-92) propõe um modelo, apresentado na ilustração 4, que segue, para o foco estratégico na competitividade ao nível da empresa. 


\section{Ilustração 4 - Modelo para obtenção da vantagem competitiva no nível empresarial}

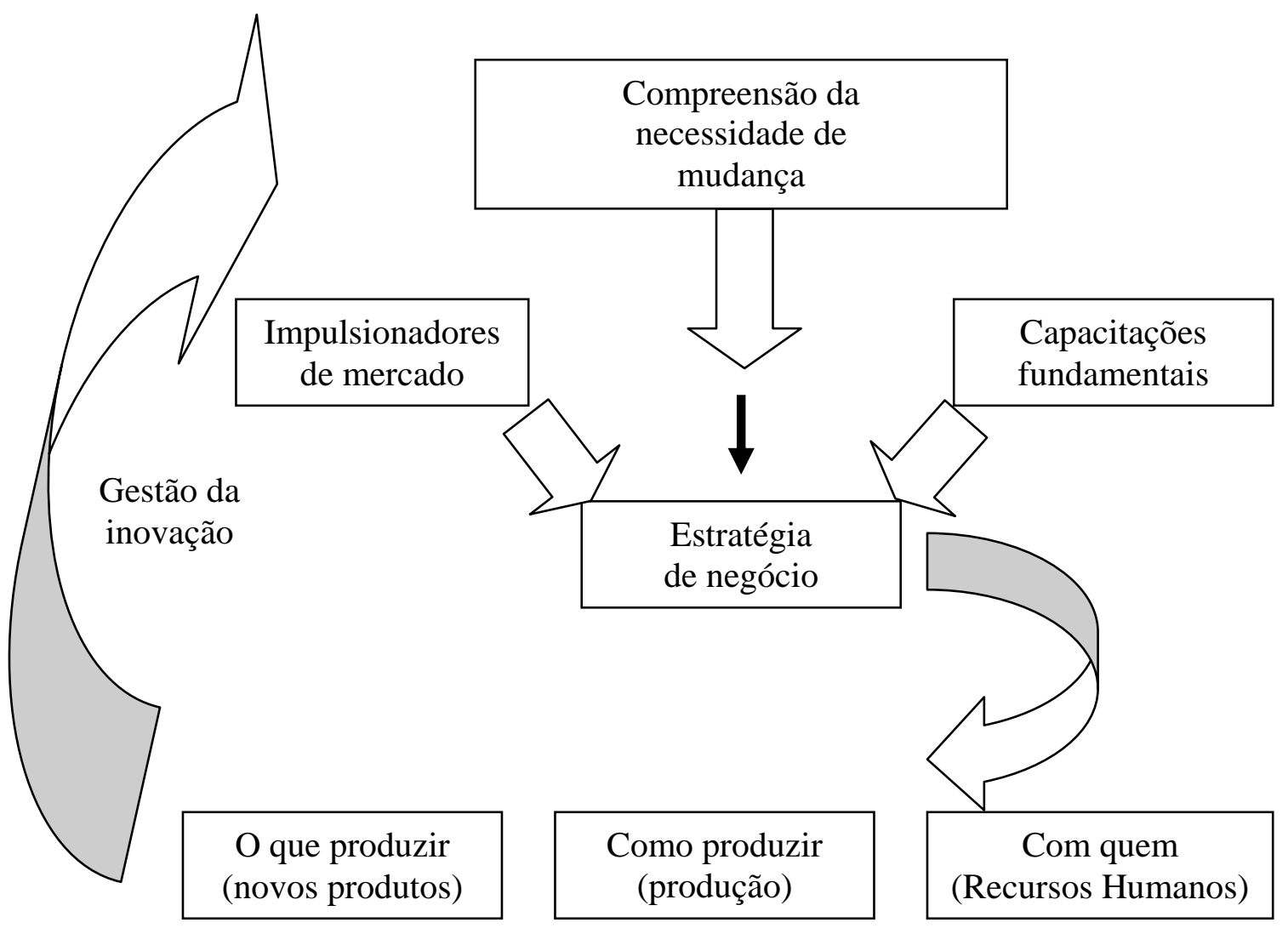

FONTE: Adaptado de KAPLINSKY, 2005, p. 89.

No tocante às capacitações fundamentais, se todas as empresas fossem iguais neste aspecto, não haveria renda a ser apropriada. A empresa deve desenvolver competências que a distinguem para poder evitar estas pressões competitivas. Há ênfase na necessidade das empresas, ao mesmo tempo em que fortalecem algumas competências e constroem outras, abandonem o que se transformou no que é chamado de constrangimentos fundamentais, definidas como competências históricas, que estorvam o desenvolvimento de vantagens competitivas dinâmicas. (KAPLINSKY, 2005, p. 92).

Schmitz e Knorringa (1999, p. 6) estudaram o aprendizado através de compradores globais pela investigação dos seguintes critérios: (1) Preço; (2) Confiabilidade na qualidade do produto; (3) Tempo de resposta (do pedido à entrega); (4) Entrega pontual; (5) Flexibilidade (separada nas possibilidades de se lidar com pedidos pequenos e de aceitar alterações em pedidos grandes); (6) Capacidade de design inovadora. Procurou-se obter respostas relacionadas à experiência do respondente. Desta forma tenta-se evitar respostas que 
contenham apenas experiências genéricas, que poderiam levar a mera repetição de clichês por parte dos entrevistados.

Porter e Wayland (1995, p. 82) observam que, em um mundo no qual a informação é rapidamente difundida e os insumos básicos estão largamente disponíveis, somente ser global não é o suficiente para sustentar a vantagem competitiva. A única forma de uma empresa manter sua vantagem competitiva é através da inovação permanente e evolução de seus atributos, de forma a torná-los mais sofisticados. Inovação não se refere somente à tecnologia física, mas também a marketing, formas de comunicação, posicionamento de produto e outras formas de competir. As empresas mais dinâmicas e inovadoras superam os concorrentes, mesmo aqueles em posições consolidadas, cuja competitividade advém de custos mais baixos nos fatores de produção ou economias de escala. A conclusão é que a vantagem competitiva decorre da taxa de melhoramento dinâmico e não de eficiências estáticas.

Williamson (1991A, p. 278) argumenta que um problema central da organização econômica é a adaptabilidade. Teece et al (1997, p. 521) argumentam que a capacidade de rever e transformar, em si, é uma competência organizacional que pode ser aprendida. Quão mais freqüente é praticada, mais fácil seu êxito.

Kaplinsky (2005, p. 92-95) explica também que a estratégia de negócios advém da interação entre os determinantes da mudança, necessidades do mercado e competências empresariais. $\mathrm{O}$ que resulta da estratégia de negócios são as estratégias funcionais com relação a produto, formas de produção e recursos humanos.

Na estratégia de produto, a natureza dinâmica dos mercados finais requer que uma empresa esteja capacitada para evoluir quanto a sua oferta de produto. Em alguns casos, esta evolução significa produtos totalmente novos, contudo, com maior freqüência envolve apenas alterações contínuas em uma família de produtos que já existe e/ou oferecer muitas variedades de produtos. A eficácia de desenvolvimento de produto eficaz emerge de uma combinação de hardware com novas e apropriadas formas organizacionais. No entanto, são as novas formas de organização que têm um efeito mais determinante para facilitar o desenvolvimento de produto. Devido à dificuldade de gestão destes processos de desenvolvimento de produtos, este aspecto se tornou uma barreira à entrada da concorrência. 
Em termos da estratégia funcional para a produção, o paradigma da produção em massa, que perdurou até meados da década de 1980, perdeu vigor. Os compradores desejam variedade, qualidade e inovação de produto. O novo paradigma tenta produzir baseado nos pedidos dos compradores, ao invés de produzir tentando prever o que o comprador deseja.

Os desafios da implementação da mudança tornam obrigatório que se invista pesadamente nas pessoas, no desenvolvimento de relações de confiança, nos processos de desenvolvimento contínuo, e nas alterações nas estruturas organizacionais. Os passos necessários para a gestão eficaz das mudanças formam uma lista conhecida: compromisso da alta administração, envolvimento da força de trabalho no desenho e implementação da mudança, capacitar a força de trabalho, introdução de sistemas de remuneração apropriados e o estabelecimento de relações de confiança que estimulem o envolvimento construtivo no processo de mudança. Contudo, também é feito o alerta sobre o fato de que a realidade é muito mais complexa.

Humphrey e Schmitz (2000, p. 3-4) utilizam o conceito de aperfeiçoamento competitivo para se referir a quatro alterações distintas que podem ser implementadas por empresas ou grupos de empresas: (1) Aperfeiçoamento de processo. Empresas podem aperfeiçoar processos - transformar insumos em produtos de forma mais eficiente através da reorganização do sistema produtivo ou através da utilização de tecnologia superior. (2) Aperfeiçoamento de produto. Empresas podem se aperfeiçoar competitivamente ao se movimentarem na direção de linhas de produto mais sofisticadas (que podem podem possam podem ser definidas em termos de seu valor unitário mais alto). (3) Aperfeiçoamento funcional. Empresas podem desempenhar novas funções na cadeia, como por exemplo design ou marketing. (4) Aperfeiçoamento inter-setorial. As empresas podem aplicar a competência adquirida em uma particular função da cadeia (e.g. competência na produção de determinados insumos ou no marketing de exportação) em um novo setor. Estes deslocamentos horizontais para novos setores parecem ter sido centrais para a habilidade de Taiwan de se posicionar em setores intensivos em conhecimento.

Enquanto a primeira forma de aperfeiçoamento envolve fazer as mesmas coisas de forma mais eficiente, as outras três formas podem levar a um reposicionamento das firmas nos mercados globais, à medida que começam a produzir produtos diferentes para outros perfis de compradores. 
Gibbon e Ponte (2005, p. 89-90) embora pontuem que se trata de uma classificação útil, vêem méritos e fragilidades nos tipos de aperfeiçoamento funcional. Um dos exemplos é a dificuldade de distinção de aperfeiçoamento de produto e de processo. Também a situação do aperfeiçoamento inter-setorial seria pouco clara, visto que se refere a uma trajetória e não a que aspecto do negócio ocorre o aperfeiçoamento. Uma outra crítica é a ênfase, considerada exagerada, no aperfeiçoamento funcional. Fica a dúvida se não haveria a sugestão que este último tipo de aperfeiçoamento seria melhor do que os demais. Ainda existem as dificuldades práticas deste caminho do aperfeiçoamento funcional, pois em muitos casos as empresas líderes bloqueiam esta possibilidade. Em alguns casos esta trajetória só seria possível se a empresa renunciar à participação na cadeia original.

Kaplinsky e Morris (2003, p. 77) apresentam exemplos de indicadores de inovação e aperfeiçoamento competitivo, que podem ser observados no quadro 3, que segue. 
Quadro 3 - Exemplos de indicadores de inovação e aperfeiçoamento competitivo

\begin{tabular}{|c|c|c|c|}
\hline \multicolumn{2}{|c|}{$\begin{array}{c}\text { TIPOS DE } \\
\text { APERFEIÇOAMENTO }\end{array}$} & PRÁTICAS & DESEMPENHO \\
\hline $\begin{array}{l}\text { MELHORA DA } \\
\text { EFICIENCIA DOS } \\
\text { PROCESSOS }\end{array}$ & $\begin{array}{l}\text { Dentro da } \\
\text { cadeia } \\
\text { Entre elos } \\
\text { das cadeias }\end{array}$ & $\begin{array}{l}\text { P\&D; alterações em logística e } \\
\text { em práticas relacionadas à } \\
\text { qualidade; introdução de novos } \\
\text { equipamentos. } \\
\text { P\&D; gestão de procedimentos } \\
\text { na gestão da vadeia de } \\
\text { suprimentos; capacitação para } \\
\text { e-business; facilitação do } \\
\text { aprendizado na cadeia de } \\
\text { suprimento. }\end{array}$ & $\begin{array}{l}\text { Custos mais baixos; melhora da } \\
\text { qualidade e desempenho de } \\
\text { entrega; tempo para o mercado } \\
\text { diminuído; lucratividade } \\
\text { aumentada; melhora na atividade } \\
\text { relacionada a patentes. } \\
\text { Idem; aumento da lucratividade } \\
\text { em toda a cadeia de valor. }\end{array}$ \\
\hline $\begin{array}{l}\text { INTRODUÇÃO DE } \\
\text { NOVOS PRODUTOS } \\
\text { OU MELHORA DE } \\
\text { PRODUTOS } \\
\text { EXISTENTES }\end{array}$ & $\begin{array}{l}\text { Entre elos } \\
\text { das cadeias }\end{array}$ & $\begin{array}{l}\text { Expansão dos departamentos } \\
\text { de marketing e design; criação } \\
\text { ou fortalecimento do } \\
\text { desenvolvimento de novos } \\
\text { produtos através de times } \\
\text { funcionais. } \\
\text { Cooperação com fornecedores } \\
\text { e clientes no desenvolvimento } \\
\text { de novos produtos. }\end{array}$ & $\begin{array}{l}\text { Participação de novos produtos } \\
\text { nas vendas. } \\
\text { Participação de produtos com } \\
\text { marcas próprias nas vendas. } \\
\text { Número de marcas registradas. } \\
\text { Aumento nos preços unitários dos } \\
\text { produtos vendidos, sem prejuízo } \\
\text { de participação de mercado. }\end{array}$ \\
\hline $\begin{array}{l}\text { ALTERAÇÃO NAS } \\
\text { ATIVIDADES }\end{array}$ & $\begin{array}{l}\text { Dentro da } \\
\text { cadeia } \\
\text { Entre elos } \\
\text { das cadeias }\end{array}$ & $\begin{array}{l}\text { Novas funções que adicionam } \\
\text { valor, específicas das cadeias, } \\
\text { absorvidas de outros elos na } \\
\text { cadeia e/ou terceirização das } \\
\text { atividades que adicionam } \\
\text { pouco valor. } \\
\text { Movimentação para novos elos } \\
\text { na cadeia e/ou abandono dos } \\
\text { elos existentes. }\end{array}$ & $\begin{array}{l}\text { Divisão de trabalho na cadeia. } \\
\text { Funções-chave desenvolvidas nos } \\
\text { elos individuais da cadeia. } \\
\text { Lucratividade mais alta; aumento } \\
\text { na capacitação e perfil salarial. }\end{array}$ \\
\hline $\begin{array}{l}\text { MOVIMENTAÇÃO } \\
\text { PARA UMA NOVA } \\
\text { CADEIA DE VALOR }\end{array}$ & & $\begin{array}{l}\text { Abandono da produção em } \\
\text { uma cadeia e movimentação } \\
\text { para outra; acréscimo de } \\
\text { atividades em uma nova cadeia } \\
\text { de valor. }\end{array}$ & $\begin{array}{l}\text { Lucratividade mais alta; } \\
\text { proporção de vendas de novas e } \\
\text { diferentes áreas de produto. }\end{array}$ \\
\hline
\end{tabular}

FONTE: Adaptado de KAPLINSKY; MORRIS, 2003, p. 77.

Mytelka (2000, p. 18-19) argumenta que poucas empresas nos países em desenvolvimento estão na fronteira tecnológica dos seus respectivos setores. Portanto, uma definição que iguale inovação à invenção é pouco útil para o planejamento empresarial, entre outros aspectos. A proposta é que o conceito de inovação abranja o aperfeiçoamento contínuo em design de 
produto e qualidade, alterações organizacionais e nas rotinas de gestão, criatividade no marketing, modificações nos processos produtivos que reduzam custos, aumentem a eficiência e garantam sustentabilidade ambiental. Inovações deste tipo são críticas para as empresas no mundo em desenvolvimento na atualidade.

Schmitz (1999B, p. 1627-1630) expõe que diversos estudos mostraram que empresas, com freqüência, obtêm uma combinação dos caminhos de alto e de baixo nível para a competitividade. Foi investigado o cluster do Vale dos Sinos no Brasil e foram obtidas indicações que o aperfeiçoamento competitivo que houve foi em boa parte limitado à esfera da produção.

Gibbon (2001, p. 360) afirma que, na verdade, nos últimos anos, o aperfeiçoamento competitivo se transformou em uma preocupação central na abordagem conhecida como cadeia global de valor. Também é sugerido que para entender o aperfeiçoamento competitivo nas cadeias globais de valor, devem ser explicitadas as estruturas de recompensa destas cadeias e a natureza dos papéis que em determinadas circunstâncias propiciam recompensas. (GIBBON, 2003, p. 21)

Humphrey (2003, vii), no entanto, destaca que trabalho mais recente sobre globalização e a posição de empresas de países em desenvolvimento na economia global colocou dúvida sobre o potencial de aperfeiçoamento competitivo contínuo e evolução de receitas (em pelo menos alguns dos clusters de países em desenvolvimento). A questão não seria somente de orientação para exportações e competição crescente na economia global. Uma das medidas de sucesso empresarial tem sido o êxito nos mercados de exportação.

Kaplinsky e Morris (2003, p. 78) apresentam exemplos de bloqueadores e impulsionadores do aperfeiçoamento competitivo, que podem ser visualizados no quadro 4, que segue. 


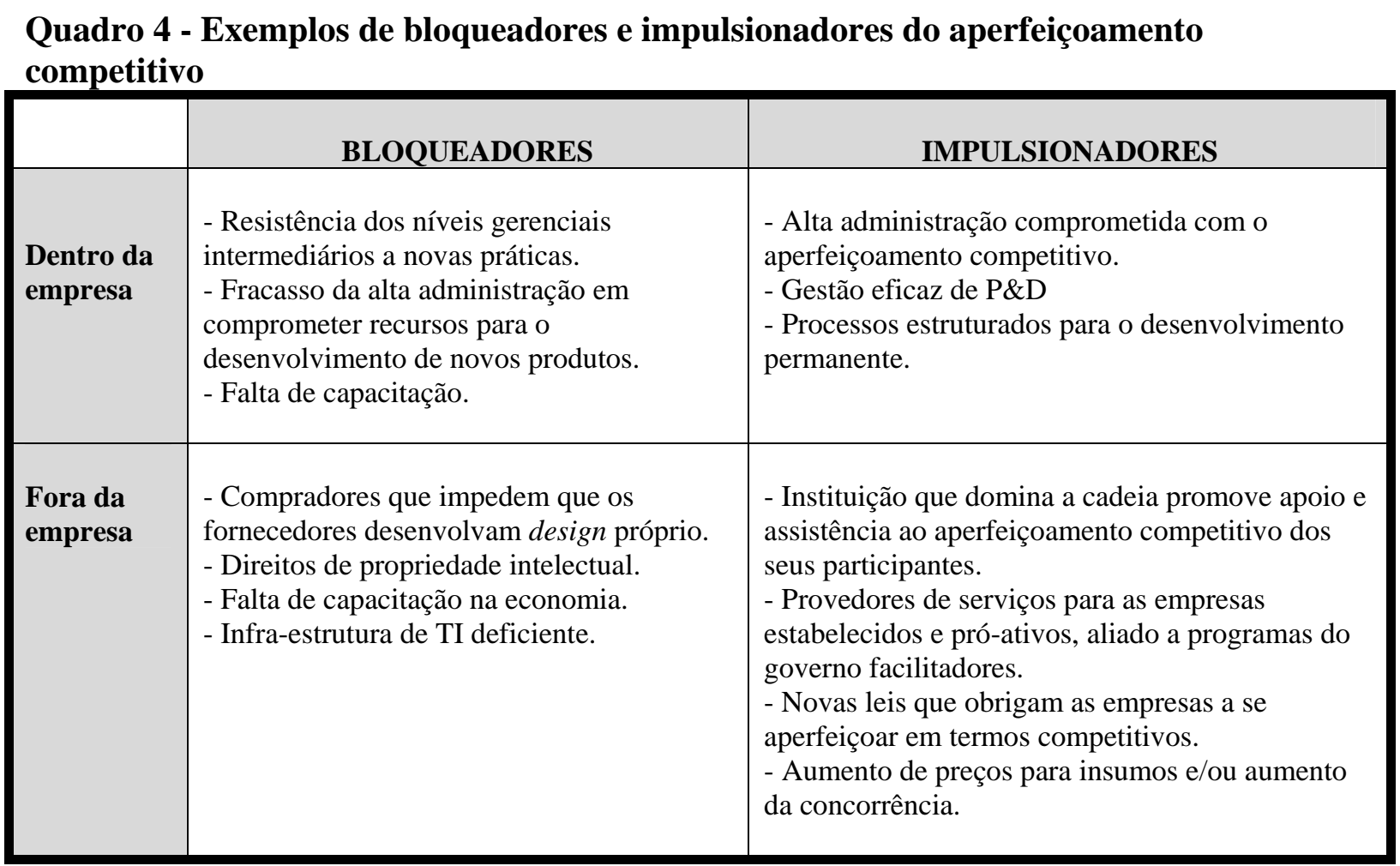

FONTE: KAPLINSKY; MORRIS, 2003, p. 78.

Schmitz (1999B, p. 1647-48) ao estudar empresas brasileiras do Vale dos Sinos, concluiu que a ênfase na busca pela competitividade não deveria ter foco no fator preço e sim em outros fatores. A ênfase não pode ser somente no aperfeiçoamento competitivo relacionado ao processo produtivo. O conflito de interesses entre os compradores de fora do país e as empresas brasileiras do Vale dos Sinos não deve ser negligenciado. Não há interesse dos compradores globais em que seus fornecedores se aperfeiçoem em termos de capacidade de design, desenvolvimento de suas próprias marcas e canais de distribuição. No caso do Vale dos Sinos, as empresas brasileiras fornecedoras dos compradores internacionais foram mantidas com firmeza na atividade de fabricação. O aprendizado pela exportação foi enorme nos anos iniciais, quando os compradores internacionais trouxeram não só uma ligação comercial, mas também ajudaram os produtores locais a aperfeiçoar seus métodos produtivos. Contudo, estes mesmos compradores obstruíram o aprendizado em períodos posteriores. A suposição é que o grau de concentração no segmento comprador influencia o resultado neste ponto. Se o número de compradores for menor, é esperado que seja mais difícil (para os produtores) o aperfeiçoamento competitivo através da movimentação na cadeia de valor.

Schmitz e Musyck (1994, p. 892) explicam que o aperfeiçoamento competitivo de alto nível (ou rota de alto nível para a competitividade) procura a competitividade através da inovação, 
ou seja, através da adoção de novas tecnologias, do desenvolvimento de produtos novos e/ou melhores e através da reação mais veloz às mudanças do mercado.

Bazan e Navas-Alemán (2001, p. 64-65) no estudo sobre o cluster calçadista do Vale dos Sinos, Brasil concluíram que lá havia uma estratégia de aperfeiçoamento competitivo por parte de algumas empresas, que privilegiava a discrição. As empresas procuravam a diversificação de mercado sem deixar de lado os compradores tradicionais. Neste caso, com exceção das empresas que redirecionavam sua produção para unidades no Nordeste brasileiro, as demais empresas da amostra estudada não pareciam seguir a rota de se concentrar em baixos custos.

Também foi verificado neste estudo que as empresas manejavam com competência a participação simultânea em várias cadeias de valor. Há considerações sobre se este evento pode ser classificado como aperfeiçoamento funcional. A conclusão é que o exame da atuação de uma empresa em uma única cadeia das várias em que participa, pode não ser suficiente para captar a real evolução das competências do caso em estudo. A empresa pode estar em trajetórias diferentes em cadeias distintas.

Schmitz e Knorringa (1999, p. 14) concluíram que as empresas fornecedoras do seu estudo diferem substancialmente na intenção de aprender com os estrangeiros e que esta diferença ajuda a explicar as alterações na sua competitividade. Neste aspecto, os gestores das empresas chinesas parecem mais desejosos de absorver e seguir recomendações técnicas e organizacionais do que os indianos. O resultado é que as empresas chinesas fizeram enormes progressos em termos de qualidade e pontualidade, de forma a se igualar ou até mesmo superar os fornecedores do Brasil.

Camuffo et al (2005B, p. 26) apresentam casos em que posições estratégicas distintas e rentáveis foram conquistadas com inovação de produto, mas a vantagem competitiva não deriva somente desta atividade. Nos casos em que as empresas integram um amplo conjunto de atividades dentro da empresa, é difícil identificar a fonte de sua vantagem competitiva. Com freqüência a vantagem competitiva nestes casos está mais na relação entre as atividades do que propriamente nestas. Os rivais encontram dificuldade em replicar o sistema integralmente, pois as relações mencionadas não são claras, além de sua intangibilidade. Até 
que os concorrentes sejam capazes de fazer engenharia reversa e implementar o sistema todo, a oportunidade de retorno diferenciado já se esvaiu.

Kilduff (2005, p. 186-191) traz conclusões sobre casos nos quais as empresas deixaram segmentos de mercado que eram atendidos com produtos sem diferenciação. Na pesquisa mencionada, houve também algum movimento na direção de segmentos menos expostos à concorrência internacional. Há segmentos em que o atendimento de compradores exigentes e relações próximas com clientes são percebidos como barreiras à entrada de concorrentes. Foram observadas empresas que internacionalizaram suas operações e aperfeiçoaram suas capacitações tecnológicas e de recursos humanos para diferenciar produtos através da criatividade e serviço melhorado. Estas empresas nos EUA foram obrigadas a intensificar a inovação de produto, aumentar a variedade oferecida e aumentar a flexibilidade e a velocidade do fornecimento, ao mesmo tempo em que diminuem custos para conseguirem permanecer com preços competitivos. Para reagir com eficácia, muitas empresas estão mais focadas em um conjunto mais estreito de competências em termos de produtos, processos, clientes ou segmentos de mercado. Algumas organizações desenvolveram um perfil comercial, focando suas competências fundamentais no conhecimento de clientes, produtos e mercados. A recomendação para os casos estudados nos EUA, para terem sucesso é que adotem uma cultura com maior adesão às mudanças e arranjos operacionais mais flexíveis. É necessário também que as empresas tenham uma orientação mais internacional, pois as alianças e parcerias com outras empresas para criar e desenvolver produtos inovadores de forma rápida e com custos baixos para compradores em vários mercados será a regra.

Dedrick e Kraemer (1998, p. 7) elaboram sobre a divergência entre a competitividade nacional versus a empresarial. No setor de informática, o interesse nacional e o empresarial divergiram nas duas últimas décadas, à medida que a cadeia produtiva legal do setor de informática evoluiu sem dar importância às fronteiras nacionais e empresariais. Uma evidência deste último fato é a cadeia criada pelas empresas americanas do setor de informática na Ásia.

Castellani (2004, p. 125-126) conclui que o aumento da produtividade é influenciado pela intensidade com que a empresa exporta e não somente por sua presença no mercado externo. Isto implica que o aprendizado ocorre somente a partir de um nível mínimo de envolvimento com o estrangeiro. No caso italiano, as evidências sugerem que apenas as empresas com alta 
orientação para os mercados externos, algo como acima de $50 \%$ da receita vinda do estrangeiro, experimentam ganhos de produtividade consideráveis. Também foi observado que o aprendizado com as atividades externas requer uma estrutura interna que permita à empresa processar e utilizar as informações e o conhecimento aos quais se teve acesso nos mercados internacionais. As empresas menores podem não ter a capacitação necessária para entrar no ciclo virtuoso do aprendizado das operações externas. As chamadas empresas de médio porte já estariam em uma posição distinta, com relação a entrar neste ciclo virtuoso.

Humphrey et al (1998, p. 17) notam que o ambiente para as empresas em muitos países em desenvolvimento têm se alterado de forma radical. As empresas têm sido expostas às pressões de uma economia globalizada. A natureza da competição tem mudado: a competição baseada no preço está sendo substituída pela competição baseada em uma amplitude maior de fatores, que incluem qualidade, respostas rápidas aos compradores e velocidade da inovação.

Ainda de acordo com Humphrey et al (1998, p. 251-252), as empresas de países em desenvolvimento enfrentam dois grupos de concorrentes: (1) Este primeiro grupo é formado por empresas de outros países em desenvolvimento, que têm como vantagem competitiva os custos baixos. A principal ameaça neste caso vem da China. A recomendação para as empresas indianas é que estas apliquem novas formas organizacionais, mesmo nas operações intensivas em mão-de-obra antes que a concorrência e sustentem o processo de forma a ampliar o processo de inovações organizacionais. Estas inovações devem permitir que as empresas estudadas compitam em outros fatores além do preço. São citados além da velocidade da resposta, qualidade, confiabilidade do fornecimento e variedade. (2) O outro grupo de concorrentes é formado por empresas cuja vantagem repousa em tecnologia e qualidade.

Embora, no caso da Índia, as empresas podem não conseguir escapar da atuação nos segmentos populares, no qual a competição de preço é intensa, é provável que as recompensas do ingresso nos segmentos superiores do mercado global ofereçam renda econômica mais alta. Embora se reconheça a dificuldade de generalizar, a recomendação para as empresas dos países em desenvolvimento é que, quanto mais elas se afastarem da competição de preço, mais capazes elas serão de obter renda crescente e sustentável. 
Dedrick e Kraemer (1998, p. 14-15) propõem uma definição para a competitividade ao estudarem o setor de informática. Embora a competitividade possa ser medida de várias maneiras, como por exemplo, lucratividade, criação de valor para o acionista, crescimento, participação de mercado e liderança tecnológica. Cada uma destas métricas é importante, contudo liderança tecnológica e crescimento são críticos no setor de informática. O fundamento racional desta afirmação está no fato de que a liderança tecnológica e o controle de padrões possibilitam que uma empresa domine o mercado e obtenha margens altas, que podem ser aplicadas em inovação. O crescimento impulsiona o ciclo da inovação ao garantir que existam investidores dispostos a financiar a expansão, funcionários talentosos dispostos a contribuir intensamente e um crescente contingente de usuários aguardando para adotar os novos produtos que a empresa lança. Não acompanhar este ritmo pode ser devastador no setor de informática, visto que os ciclos de produto podem ser medidos em meses e os lucros são obtidos nos primeiros meses. Empresas de baixo crescimento podem cortar custos e se manter rentáveis por um período, mas o declínio será irreversível se os funcionários, acionistas e fornecedores começarem a abandonar a empresa.

Um determinante crítico do sucesso competitivo é a eficácia com que as empresas chegam aos mercados externos e estabelecem relações com o sistema global de produção. As empresas que falham em crescer além do seu mercado doméstico, não têm sucesso em manter altas taxas de crescimento e alcançar os níveis de vendas necessários para reduzir os custos de produção e recuperar os custos de desenvolvimento de produtos. Aquelas empresas que mantém as atividades produtivas nos países de origem e dependem de seus fornecedores domésticos fracassam em aproveitar as capacitações distribuídas ao longo do sistema global de produção.

Sobre competitividade internacional, Ezeala-Harrison (1999, p. 47-54) afirma que se trata de um conceito razoavelmente difícil e controverso. Há pouca convergência com relação a sua definição precisa. Há divergência sobre as métricas utilizadas e sobre a interpretação dos resultados que emergem destas métricas.

É realizada uma distinção entre vantagem competitiva e competitividade. A vantagem competitiva representa um potencial estático, que pode, ou não, ser transformado em competitividade. A vantagem competitiva é uma condição necessária, porém não suficiente, para que se alcance a competitividade. 
Pietrobelli (1998, p. 149-151) afirma que em setores abertos e dinâmicos, caracterizados por uma alta taxa de mudança em seus produtos, as exigências em termos de design, tecnologia e informação são maiores, o design do produto é alterado com freqüência e as redes de distribuição mais extensas. As exigências para a competitividade em um mercado dinâmico compreendem necessariamente a adesão a investimentos em capacitação tecnológica. Estes investimentos implicam custos adicionais para o aperfeiçoamento da engenharia de produto e de processos. Também incluem a adaptação do design de produtos, sua apresentação e aspectos relacionados ao controle de qualidade.

Kogut (1985, p. 31-33) distingue três formas de competir: (1) Competição baseada na vantagem comparativa (de um país). Neste caso a concorrência ocorre entre exportações de commodities de países com dotações semelhantes de fatores. (2) Esta forma de competir se baseia nas diferenças da cadeia de vantagem competitiva entre as empresas. Se os custos relativos dos fatores entre as nações são semelhantes, então a competição a concorrência está nas diferenças entre as vantagens competitivas das empresas. A concorrência neste caso se caracteriza pelos fluxos cruzados de comércio de produtos similares e IDE para penetração de mercados. (3) Esta forma de competir consiste na interação entre vantagem competitiva e vantagem comparativa. Sempre que as diferenças nas vantagens comparativas promovem comércio intra-setorial ou investimentos horizontais em outros países, a combinação de vantagens competitivas e comparativas resulta em um padrão complexo de dispersão internacional das atividades das empresas. Nesta forma de concorrência, as empresas competem com base na sua superioridade em termos de configuração das fontes e fornecimento (muitas vezes localizadas em outros países), vantagens competitivas e decisões de produto-mercado.

Haveria três fontes de vantagem competitiva global: (1) Aumento nas economias de escala como resultado de um mercado maior. (2) Aumento nas economias de escopo, como resultado de uma linha de produtos maior, de forma a possibilitar maior absorção de custos fixos. (3) Maior experiência, resultante de conhecimento adquirido com oportunidades de marketing ou novas tecnologias.

O quadro 5, que segue, apresenta um resumo dos modos de competição internacional. 


\section{Quadro 5 - Modos de competição internacional}

\begin{tabular}{|c|c|c|}
\hline & Vantagens com & tivas de países \\
\hline & Sem vantagem & Com vantagem \\
\hline $\begin{array}{c}\text { Sem } \\
\text { vantagem }\end{array}$ & Mercados segmentados nacionalmente & $\begin{array}{l}\text { Comércio inter-setorial } \\
\text { Integração vertical internacional das empresas }\end{array}$ \\
\hline $\begin{array}{l}\text { Vantagens } \\
\text { competitivas } \\
\text { de empresi } \quad \text { Com } \\
\\
\\
\text { vantagem }\end{array}$ & $\begin{array}{l}\text { Comércio intra-setorial } \\
\text { Integração horizontal internacional das } \\
\text { empresas }\end{array}$ & $\begin{array}{l}\text { Empresas com integração horizontal e vertical } \\
\text { com diferentes configurações de penetração de } \\
\text { mercado e fontes de abastecimento. }\end{array}$ \\
\hline
\end{tabular}

FONTE: KOGUT, 1985, p. 33.

Kogut (1985, p. 26-27) conclui que há diferença entre competir com base na transferência inicial de uma vantagem, através da exportação de um produto a partir de uma unidade favorecida pela sua localização e a vantagem de uma empresa pelo investimento externo e competir com base nas vantagens obtidas por ser global.

Bradford Jr. (1994, p. 72) discorre sobre as novas dimensões da competitividade internacional, fruto das tendências tecnológicas observadas nas últimas décadas: (1) Qualidade. Até a década de 1970, havia a crença de que menor custo significava obrigatoriamente menos qualidade. As novas tecnologias e técnicas produtivas, bem como organizacionais, alteraram este paradigma. O resultado é que a qualidade se transformou em um elemento importante da competitividade. Para ser competitivo na atualidade, em muitas áreas não significa apenas a produção ao menor custo possível. Em muitas áreas, a qualidade é tão ou mais importante que o custo baixo. (2) Reatividade às necessidades dos compradores e entrega ágil. Com os ciclos operacionais encurtados, a capacidade de responder às necessidades do comprador e entregar rápido se transformou em elemento importante de competitividade. (3) Elementos dentro da empresa. Dentre estes, se destacam a escolha de produtos, o organização e o design. O desempenho eficiente nestas áreas depende da qualidade da gestão e dos administradores e também do quão apropriadas são as decisões da empresa quanto a executar tarefas internamente em contrapartida a fazê-las fora. (4)

Relações inter-empresariais. Crucial, pois há um crescimento nas relações entre as empresas. 
Roberts e Thoburn (2004, p. 132) notam que as fontes e os fundamentos da competitividade internacional estão intimamente ligados à liberalização do comércio. Na África do Sul, verificou-se que o legado de altos níveis de proteção teve o duplo efeito de fazer com que as empresas sejam relativamente pouco competitivas onde isto ocorreu. Ao mesmo tempo este evento foi capaz de forjar empresas com flexibilidade para responder a distintas necessidades de compradores.

Dedrick e Kraemer (1998; p. 239-240) concluem no estudo sobre o setor de informática em países do Leste asiático que, além da gestão ser fundamental para o sucesso empresarial, esta inclui a capacitação para administrar em um ambiente internacionalizado. É evidente que experiência conta, mas a educação é a forma de se desenvolver neste aspecto. Marketing é outra função crítica dentro da gestão, pois as empresas devem procurar oportunidades de mercado, estabelecer canais de distribuição, prover suporte e tentar construir o relacionamento de marca.

Rugman e D’Cruz (2000, p. 1) notam que tradicionalmente a estratégia empresarial se concentrava na rivalidade (entre concorrentes), e o tema estrutura, na hierarquia. Contudo, estas abordagens estariam sendo abandonadas em prol da idéia que a competitividade internacional sustentável só pode ser obtida através de relações de cooperação, em uma estrutura empresarial do tipo rede.

Com relação à exportação, Wortzel e Wortzel (1981, p. 51) identificaram cinco estágios de exportação pelos quais as empresas podem passar. Cada estágio é caracterizado pela internalização da produção e das funções e decisões de marketing que anteriormente eram desempenhadas pelos clientes da empresa. No entanto, a conclusão é que não há uma estratégia específica, ou estágio exportador específico que seja ótimo para todas as empresas de um setor ou para todos os setores, ou para todos os países.

Kogut (1985, p. 11-13) argumenta que as vantagens competitivas das empresas impedem que as vantagens comparativas predominem. Especificamente, as empresas podem tirar vantagem de certas economias ao longo e também entre as cadeias de valor agregado, que criam vantagens competitivas, que podem ser transferidas globalmente. Três economias são especialmente relevantes: escala, escopo e aprendizado. Este aspecto é de importância na análise relacionada à interação entre vantagem competitiva e vantagem comparativa. Nas 
situações em que as empresas obtêm vantagem competitiva em termos de escala, escopo ou aprendizado, podem se encontrar em desvantagem quanto à localização, mas ainda competir com êxito. Em outras palavras, a vantagem competitiva de uma empresa pode superar (e compensar) a desvantagem comparativa de uma localização em determinado país. Em setores caracterizados pela diferenciação de produtos, as empresas podem reagir à competição internacional através do investimento em novas vantagens competitivas.

Sobre competitividade, Cassiolato e Lastres (2000, p. 33) afirmam que é largamente reconhecido que a capacidade de gerar e utilizar conhecimento é o elemento mais importante da competitividade sustentável e do crescimento das empresas.

Humphrey (2003, p. 18-19) coloca que a perspectiva GVC também traz algumas sugestões sobre os desafios que as empresas enfrentam à medida que tentar se aperfeiçoar competitivamente e se reposicionar dentro das cadeias globais. Um problema particularmente importante para empresas que lograram se inserir com êxito nas GVCs caracterizadas por relações quasi-hierárquicas é o perigo de ficarem travadas nesta posição. Nestes casos, as empresas se dão conta que uma grande parcela de sua receita advém de um pequeno número de compradores e se tornam especializadas em uma atividade em especial, normalmente a produção. É comum que as empresas não desenvolvam capacitação em marketing ou design, ou deixem que estas capacitações se atrofiem devido às características do relacionamento com o comprador global. As empresas nesta situação se tornam pesadamente dependentes destes relacionamentos. Do ponto de vista do comprador, como este investe na capacitação do fornecedor, pode demandar exclusividade. O objetivo neste caso é impedir que seus concorrentes obtenham ganhos com seu investimento (no fornecedor). Pode ser oneroso ao fornecedor mudar de compradores ou de mercados e, ao mesmo tempo, está vulnerável à competição de novas formas de fornecimento, que compradores globais frequentemente desenvolvem como parte de sua estratégia de abastecimento global.

Nestas circunstâncias, o primeiro alvo estratégico deve ser evitar ficar travado em relacionamentos que são vulneráveis a novas formas de competição. As principais opções estratégicas para combater este travamento são:

- Diversificação de mercados. Empresas raramente produzem somente para um mercado. Pode-se promover a diversificação de mercados através da inteligência de exportação e do apoio para participação em feiras comerciais. Nos casos em que as empresas 
são particularmente dependentes de alguns grandes clientes e relutantes quanto à diversificação, então esforços na direção de diversificar podem ser direcionados para empresas menores, que normalmente produzem para outros mercados.

- Excelência produtiva. Seria incorreto supor que as barreiras de entrada são sempre baixas na etapa de produção. Pode haver, de fato, barreiras à entrada baixas em operações básicas, mas há possibilidades de aperfeiçoamento do desempenho na produção de roupas para o mercado de massa. Fornecedores com este perfil preferem não só servir ao mercadoalvo, mas estão também preocupados com os atributos do fornecimento, o que inclui qualidade e consistência de qualidade, velocidade de entrega e velocidade de resposta às mudanças no design de produtos. Tudo isto coloca maior ênfase em serviços de apoio, como infra-estrutura logística, o que pode incluir instalações e serviço de armazenagem, aeroportos e modernização de portos.

- Uso eficaz de conhecimento adquirido dentro da cadeia de valor. O efeito do aprendizado através da exportação é conhecido. Empresas aprendem através do contato com novos mercados. Visto que a inserção em cadeias de valor cria fluxos de informação significativos entre produtores e compradores, este efeito-aprendizado é potencializado. No entanto, as vantagens plenas deste efeito dependem da forma como este aprendizado é utilizado. Em alguns casos, pode ocorrer a alavancagem do conhecimento entre mercados. Nas situações em que empresas ou grupos de empresas vendem para diferentes mercados, elas podem alavancar o conhecimento obtido em um mercado para apoiar o aperfeiçoamento competitivo em outro mercado.

Duguid (2005, p. 495 e 510) exemplifica com o caso de empresas portuárias, que continuaram a operar em redes diversas e foram prejudicadas do ponto de vista competitivo.

Elfring e Baven (1996, p. 223) concluíram que a habilidade de aprender de clientes exigentes e usuários líderes em serviços de software pareceu ser crucial para o aperfeiçoamento da capacidade funcional das empresas estudadas. Também se concluiu que a construção de competências não ocorre somente dentro das fronteiras da empresa. Algumas empresas aprenderam que suas competências em serviços intensivos em conhecimento podem ser aperfeiçoadas pelo desmembramento externo das mesmas. 
Dedrick e Kraemer (1998, p. 211-215) chegaram a algumas conclusões sobre o sucesso competitivo no setor de informática: (1) As empresas bem sucedidas são altamente focadas em um segmento alinhado as suas capacitações. (2) Estas empresas são capazes de definir novos mercados ou aproveitar oportunidades em mercados criados pelos outros. (3) As empresas de maior sucesso têm rapidez e flexibilidade para decidir, o que permite a elas reagir rapidamente a um ambiente de rápidas mudanças tecnológicas e de mercado.

A implicação desta rapidez e flexibilidade que são necessárias para competir em alguns segmentos do setor de TI no mundo é que há uma tendência da estrutura de mercado resultante de favorecer as empresas menores. As empresas menores normalmente são mais focadas do que as maiores. Outro aspecto que favorece as organizações de menor porte está relacionado à inexistência de custos irrecuperáveis (sunk costs) de investimentos prévios. Portanto, este perfil de organização pode alterar o rumo rapidamente para reagir às novas oportunidades. É mencionada também a gestão pelo dono em empresas menores, o que as torna mais ambiciosas. A busca de novas oportunidades de mercado é feita com agressividade, há possibilidade e desejo de quebrar regras para que objetivos sejam atingidos com rapidez. Há os alertas que estas generalizações não são sempre verdadeiras e que mais importante do que o porte da organização são os aspectos relacionados à cultura empresarial e ao estilo de gestão.

Ao tentar responder como produtores de móveis da África do Sul podem se aperfeiçoar competitivamente, Kaplinsky et al (2003, p. 7) argumentam que a abordagem GVC joga luz na forma pela qual os produtores entram em mercados globais. Também se argumenta que a capacitação crescente de produtores independentes resulta não só dos esforços dos compradores, mas também da tendência das empresas multinacionais de terceirizar atividades de manufatura e se concentrarem em atividades como design, tecnologia, desenvolvimento de marcas, logística, marketing e serviço pós-venda.

Ao procurar respostas sobre a existência de uma seqüência no aperfeiçoamento competitivo em cadeias de valor, Kaplinsky et al (2003, p. 34) apresentam a ilustração 5 a seguir: 
Ilustração 5 - Seqüência de aperfeiçoamento competitivo em cadeias de valor
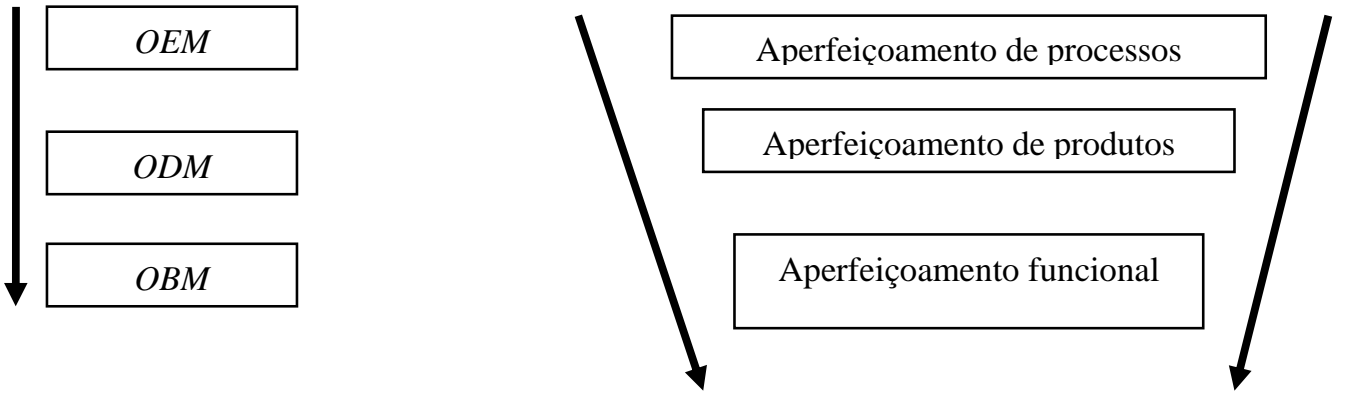

Aperfeiçoamento entre cadeias

FONTE: KAPLINSKY ET AL, 2003, p. 34.

Schmitz e Knorringa (1999, p. 23) resumem que aperfeiçoamento competitivo se trata de se movimentar para atividades que oferecem renda mais alta. Também apresentam o quadro 6 que segue, no qual podem ser observados os determinantes que consideram mais estratégicos e relevantes para o aperfeiçoamento competitivo.

Quadro 6 - Aperfeiçoamento competitivo e oportunidades

\begin{tabular}{|l|l|l|}
\hline \multirow{2}{*}{ SEGMENTO DE MERCADO } & \multicolumn{2}{|c|}{$\begin{array}{c}\text { CONCENTRAÇÃo DOS } \\
\text { COMPRADORES }\end{array}$} \\
\cline { 2 - 3 } & \multicolumn{1}{|c|}{ Alta } & \multicolumn{1}{|c|}{ Baixa } \\
\hline \multirow{2}{*}{ Foco em preço } & $\begin{array}{l}|c| \\
\text { Aperfeiçoamento competitivo: } \\
\text { baixo } \\
\text { Ganhos: assimétricos }\end{array}$ & $\begin{array}{l}\text { Aperfeiçoamento competitivo: baixo } \\
\text { Ganhos: equilibrados }\end{array}$ \\
\hline \multirow{2}{*}{ Foco em qualidade } & $\begin{array}{l}\text { Aperfeiçoamento competitivo: } \\
\text { alto } \\
\text { Ganhos: assimétricos }\end{array}$ & $\begin{array}{l}\text { Aperfeiçoamento competitivo: alto } \\
\text { Ganhos: equilibrados }\end{array}$ \\
\hline
\end{tabular}

FONTE: SCHMITZ; KNORRINGA, 1999, p. 24.

Sturgeon (2002, p. 486-488) indica que a maior diferença entre as redes modulares com raízes no contexto institucional dos EUA e outros modelos de rede específicos que aparecem na literatura (japoneses, europeus e das diásporas chinesas) é o caráter relativamente aberto destes últimos. O grau de abertura da rede teria origem nos esforços de todos os integrantes da rede de limitar a dependência mútua. 
Kaplinsky e Morris (2003, p. 43) ao tentar entender os determinantes da distribuição da renda nas cadeias de valor, argumentam que a única maneira pela qual a renda de uma empresa pode crescer de forma sustentada é através de uma barreira duradoura à entrada (de novos concorrentes). Nos casos em que as barreiras à entrada são passageiras, a empresa, região ou país precisam desenvolver a capacitação dinâmica de se movimentar de forma sistemática para atividades nas quais altas barreiras prevalecem.

Ao dar foco na natureza das barreiras à entrada em cada uma das ligações da cadeia de valor, bem como na coordenação das atividades entre seus elos (origem dos chamados renda relacionais), a cadeia de valor é capaz de explicar uma parte significante da distribuição dos resultados que advém da participação em sistemas de produção nacionais e internacionais. Este tipo de renda é classificada de endógena ou de barreiras à entrada, isto é, criadas diretamente pelos próprios participantes da cadeia.

No entanto, haveria uma série de barreiras à entrada, relacionadas à dinâmica das redes globais de valor, que são exógenas às atividades das cadeias de valor. Por exemplo, empresas em uma determinada localidade podem obter vantagens advindas das externalidades, isto é da presença de outras empresas ou capacitações que as apóiam na busca da eficiência.

Sturgeon (2003, p. 52) nota que a TI é um conjunto de ativos que é crítico para a modularidade da cadeia de valor. No caso da indústria eletroeletrônica, ocorreria a evolução em duas direções, simultaneamente: (1) Na direção de sistemas proprietários que aumentam a especificidade de ativos e a imobilidade; e (2) Na direção de sistemas abertos ou terceirizados que apóiam a modularidade da cadeia de valor de forma mais eficaz, mas possibilitam vazamentos.

Bazan e Navas-Alemán (2001, p. 1) estudaram empresas de calçados do Vale dos Sinos no Brasil e concluíram que a situação mais comum no caso examinado é o envolvimento em várias cadeias de valor simultaneamente. Desta forma, também a situação mais comum é a exposição a diferentes padrões de governança e aperfeiçoamento competitivo ao mesmo tempo.

Humphrey e Schmitz (2000, p. 11-12) comentam que há pouca convergência quanto à questão de como a governança de cadeias por parte de compradores globais afeta o aperfeiçoamento 
competitivo dos produtores locais. A visão mais otimista seria a de Gereffi (1999), baseada na sua pesquisa da cadeia de confeccionados têxteis. A partir da análise do trabalho de Gereffi, é possível concluir que os produtores que obtém acesso às cadeias globais contam com perspectivas favoráveis de se movimentarem dentro da atividade de produzir e subsequentemente passarem a desempenhar outras atividades dentro da cadeia, como por exemplo, design, marketing e o desenvolvimento de suas próprias marcas. Estas evoluções seriam conseqüências de uma combinação do aprendizado através da atividade de exportação e da sucessão organizacional.

Humphrey e Schmitz (2000, p. 12-13) argumentam que o trabalho de Gereffi não pode ser generalizado. Três questões relativas ao aperfeiçoamento teriam que ser respondidas: (1) Aperfeiçoamento na esfera da produção. Há enorme convergência na literatura a respeito do fato de produtores locais aprenderem com os compradores globais sobre os aperfeiçoamento de processos produtivos, obterem alta qualidade de forma consistente e aumentarem a velocidade de resposta. Estes aperfeiçoamentos seriam particularmente importantes para produtores locais novos no mercado global. Humphrey e Schmitz (2000, p. 12) estão de acordo com a idéia que o aperfeiçoamento dos produtores integrados na cadeia é acompanhado da exclusão de outros, que participam destas cadeias. (2) Aperfeiçoamento de produto através da sucessão de compradores. De acordo com Humphrey e Schmitz (2000, p. 12), o termo sucessão organizacional é utilizado por Gereffi para fazer referência a um processo pelo qual os fabricantes começam a produzir para compradores nos segmentos menos sofisticados do mercado. Na seqüência, estes produtores se voltam para compradores que têm foco em segmentos mais sofisticados. De início, Humphrey e Schmitz (2000, p. 12) consideram que este cenário parece plausível. No entanto, haveria três aspectos que exigem um exame mais cuidadoso. Primeiro, é necessário investigar em que extensão este movimento em direção a um segmento mais sofisticado é uma simples conseqüência do aprendizado pela exportação, ou se é o resultado de um esforço de aperfeiçoamento dos produtores. Segundo, este aperfeiçoamento pode conflitar com o interesse de compradores estabelecidos. Terceiro, o aperfeiçoamento de produto não exige necessariamente a substituição dos compradores. Sugere-se que o reposicionamento geral de uma cadeia pelos compradores, traz oportunidades de aperfeiçoamento para os fornecedores que já estão conectados. A pesquisa de redes estratégicas, nas quais a empresa dominante está permanentemente envolvida na atração e seleção de membros, em desmembrar atividades, em entrar em novas alianças, na manutenção de relações do tipo rede (o que faz através da gestão 
de conflitos e aprendizado) em posicionar e reposicionar a rede no mercado etc. (3)

Aperfeiçoamento funcional. Pesquisas realizadas na cadeia calçadista sugerem que em algumas cadeias os compradores globais desestimulam, quando não obstruem, as atividades relacionadas a design, marketing e desenvolvimento de marcas próprias. Humphrey e Schmitz (2000, p. 13) aderem à ênfase na qual os produtores locais enfrentam obstáculos devidos ao fato de que este tipo de aperfeiçoamento invade o terreno representado pela competência central dos compradores.

Humphrey e Schmitz (2000, p. 13) concluem que estas considerações levam a uma avaliação mais cuidadosa das oportunidades de aperfeiçoamento local, precisamente devido ao fato de que a cadeia global de governança pode criar barreiras ao aperfeiçoamento competitivo. Esta argumentação suporta a afirmação de que enquanto as atividades produtivas são cada vez mais globalizadas, as atividades de inovação estratégica permanecem concentradas nos países-sede das empresas globais.

Ponte (2006, p. 26) apresenta argumentos para descrever a tendência no sentido de formas de coordenação menos formais entre as empresas líderes e seus fornecedores (ou compradores) e o movimento que chama de “o mundo em rede” (PONTE, 2006, p. 26, tradução nossa). Contudo, isto não significa que as GVCs estão se tornando menos dirigidas que no passado, apenas que a forma de dirigi-las está se alterando. Pode ocorrer simultaneamente uma coordenação informal e um grau de dirigibilidade alto, ou o contrário.

Também é feito um alerta sobre a diferença entre coordenação e governança. Uma GVC pode ser coordenada de várias formas em seus diferentes segmentos, embora conte com uma forma de governança relativamente coerente.

Schmitz e Knorringa (1999, p. 19-21) encontraram pouca evidência de aperfeiçoamento competitivo fora das atividades relacionadas à produção na pesquisa realizada no Vale dos Sinos no Brasil. Se os fornecedores tentassem o caminho do aperfeiçoamento competitivo fora das atividades produtivas é pouco provável que obtivessem o apoio dos compradores. A razão estaria relacionada a razões de governança da cadeia. Nas cadeias verticais se confirmou que a fonte de poder repousa de forma crescente nas atividades não relacionadas à produção. Outro fator mencionado, que influencia de maneira fundamental o aperfeiçoamento 
competitivo dos fornecedores para atividades não relacionadas à produção é o grau de concentração dos compradores.

Bazan e Navas-Alemán (2001, p 63) também estudaram as empresas calçadistas do Vale dos Sinos e concluíram que as cadeias de valor dos EUA exibem um padrão mais hierárquico de governança. Na seqüência estão as cadeias européias. O mercado doméstico no setor estudado é caracterizado por relações de mercado. No caso das relações na América Latina, foi encontrado um híbrido: é quasi-hierárquica para as empresas que utilizam agentes de exportação nesta região e de mercado para àqueles que efetuam vendas diretas (normalmente empresas que lograram desenvolver marcas de prestígio nestes mercados).

Dedrick e Kraemer (1998, p. 221) ao pesquisarem o setor de informática na Ásia verificaram as recompensas que decorrem da ligação com o sistema global de produção. A mais óbvia é o acesso aos mercados externos, seja através dos canais de distribuição das multinacionais, ou através das exportações diretas aos distribuidores locais. Quase tão importante quanto estes aspectos óbvios, são as informações de mercado que fluem de modo reverso através destas ligações. Em setores de rápidas mudanças, é crítico ter a informação no tempo apropriado sobre as tendências de mercado onde os acontecimentos são mais dinâmicos e à frente dos eventos dos mercados dos países em desenvolvimento. Um outro benefício é o fluxo de tecnologia aos produtores locais através das interações com as multinacionais.

Há várias formas de estabelecer ligações com as redes produtivas globais. Uma das maneiras é através da atração e desenvolvimento de atividades em conjunto com as multinacionais. As multinacionais, ao se instalarem provêem um canal pronto para ser usado pelas empresas locais. Há também o estímulo que trazem para que as empresas locais alcancem o chamado padrão global para que possam competir ou vender para as multinacionais.

Hamilton et al (2004, p. 6) argumentam que poucos teóricos de qualquer inclinação incorporam os fatores organizacionais em suas explicações causais para o desenvolvimento econômico em regiões e nações.

Dosi (1997, p. 468) alerta sobre a existência da versão ingênua, na qual o arquétipo organizacional estadunidense é o único e o melhor modo de construção de competências. Também alerta sobre a expectativa da existência de correlação positiva entre a 
americanização da estrutura industrial e crescimento. Uma versão mais sofisticada argumentaria que existem múltiplas formas organizacionais. Estas podem produzir uma eficiência na coordenação e um potencial de aprendizado que equivalem àquelas produzidas pela estrutura estadunidense. Um exemplo é a Itália, o país com maior crescimento no período pós Segunda Guerra Mundial após o Japão e que é também, provavelmente, a única grande economia que manteve grande distância do modelo americano. Dinamarca e Suécia têm crescido à velocidade comparável (à Itália), mas enquanto a Suécia desenvolveu grandes empresas dominadas por gerentes profissionais, a Dinamarca se baseou em uma rede de empresas de tamanho pequeno e médio. Sturgeon (2002, p. 481) também apresenta modelos em rede específicos para cada país.

Williamson (1975, p. 104-105 e 117) conclui que a integração vertical em algumas situações parece ser uma escolha mais apropriada, devido à economia no custo de transação advinda da harmonização de interesses e por permitir a ativação de incentivos e processos de controle mais variados.

Sturgeon (2002, p. 485) expõe que as empresas americanas permaneceram excessivamente fragmentadas e focadas em corte de custos, além de terem demasiado interesse nos lucros de curto prazo. Estes fatores impediram que as empresas americanas parassem a erosão competitiva na economia global. Ao invés de responderem ao aumento da competição externa com o aperfeiçoamento competitivo de todo o sistema produtivo, o entendimento é que as empresas americanas estariam procurando obter as vantagens competitivas de baixo nível. Entre as práticas que confirmariam esta percepção, está a redução de níveis hierárquicos (downsizing), o envio da produção para localidades com salários mais baixos, pressionar fornecedores, redução de salários e a utilização de um maior número de trabalhadores temporários.

Dosi (1997, p. 468-478) também coloca que entre as capacitações associadas às formas de organização, que podem diferenciar uma empresa, está a habilidade de coordenar processos complexos de produção e distribuição. Estas capacitações podem estar em habilidades estratégicas da alta administração; ou alternativamente podem ser propriedade coletiva, relacionada ao conjunto de rotinas organizacionais que a firma incorpora. 
Schmitz (1999A, p. 139) lembra que os anos recentes finalmente confirmaram que a produção comandada, seja em uma economia de planejamento central, seja em uma fábrica integrada verticalmente ao estilo fordista, não traz resultados satisfatórios. Está confirmada a noção de que os agentes econômicos são mais produtivos nas situações em que têm alguma autonomia e se concentram nas suas competências básicas.

Fear (1997, p. 566-567) aborda a dificuldade de superar as trajetórias ou caminhos de dependência do passado (path dependence). Williamson (1975, p. 200) já mencionava que a dependência de uma empresa com relação a seu passado é um tema de especial interesse, visto o constrangimento que impõe às opções disponíveis em qualquer ponto no tempo do ciclo de vida de uma empresa. Barney (1991, p. 99) também dá indicação da importância do conceito de dependência do passado, ao afirmar que, embora os recursos estratégicos sejam distribuídos de forma heterogênea entre as organizações, estas diferenças são estáveis ao longo do tempo. Os atributos de uma empresa que em uma determinada circunstância podiam ser considerados recursos, em uma nova estrutura setorial podem ser irrelevantes ou até representar uma fragilidade para a organização. (BARNEY, 1991, p. 103).

Williamson (1996, p. 240-241) relaciona os conceitos dependência do passado e governança. A dependência do passado explica as forças e fraquezas dos diferentes modos de governança. Teece et al (1997, p. 522-523) apresentam o conceito de dependência do passado: os caminhos que uma empresa pode seguir dependem de sua posição corrente e dos caminhos à frente. A posição corrente é, com freqüência, modelada pelos caminhos trilhados pela empresa no passado. Este conceito traz a noção do peso da história. Os investimentos prévios e repertório de rotinas constrangem seu comportamento no futuro. A conseqüência é que as oportunidades de aperfeiçoamento estão próximas das atividades previamente desenvolvidas.

Os problemas burocráticos da integração vertical são produtos da experiência e ilustram a importância do passado. Quanto maiores e mais duradouros os efeitos em questão, maior o desafio. Também é notada a dificuldade de se quantificar a significância da dependência do passado. Há controvérsia sobre a associação entre a dependência do passado e a eficiência em uma organização; avaliada esta ineficiência ao se comparar uma condição real com um ideal hipotético. (WILLIAMSON, 2002, p. 1105). 
Cooke e Morgan (1998, p. 16) também abordam o tema da dependência do passado. Chamam esta perspectiva de evolucionária e notam que um desafio fundamental para as empresas é a obtenção de um equilíbrio entre as rotinas, de um lado, e a criatividade, de outro. A durabilidade das rotinas explicaria porque muitas mudanças tecnológicas e organizacionais tendem a ter dependência do passado. O aprendizado é o que ajuda a empresa na obtenção deste equilíbrio. A capacidade de aprender, por sua vez, dependeria da capacidade de absorção. A capacidade de absorção é a capacidade da empresa, reconhecer, assimilar e explorar conhecimento, interno e externo.

A dependência do passado também é abordada por Humphrey et al (1998, p. 251). Em um contexto de mudança radical no ambiente externo, como a que está ocorrendo em muitos países menos desenvolvidos, a dependência do passado coloca grandes constrangimentos na capacidade de uma empresa responder criativamente às circunstâncias dinâmicas.

Teece et al (1997, p. 509) enfatizam a importância do conceito de dependência do passado nas situações em que existem condições de rendimentos crescentes. O conceito é aprofundado na definição de conceito de competências dinâmicas; onde o dinamismo está relacionado à capacidade de renovação. O termo competências enfatiza o papel fundamental da gestão estratégica para conduzir de forma apropriada a adaptação, integração e remodelagem interna e externa das habilidades da organização, recursos e competências funcionais. Em ambas as definições, dinamismo e competências, a idéia é o alinhamento às necessidades do ambiente empresarial em constante evolução. (TEECE ET AL, 1997, p. 515).

Knight e Cavusgil (2004, p. 137) também concluem que na ausência do peso de uma herança administrativa, empresas que começaram mais recentemente e de menor porte, desempenham um papel de maior importância no contexto internacional.

Schmitz e Knorringa (1999, p. 14) confirmam esta percepção em estudo que inclui empresas da Índia e da China. Explicar o maior avanço relativo das empresas chinesas com fatores culturais parece menos tentador do que reconhecer a dependência do passado. No caso das empresas indianas, o mercado garantido da União Soviética até 1991 e a falta de concorrência no mercado interno é colocada como uma explicação mais convincente para a complacência. Resguardadas as diferenças de nível, a abordagem dos gestores italianos quanto ao aprendizado com estrangeiros converge com a dos indianos. A conclusão sugerida é que há 
uma correlação entre desejo de aprender de visitantes estrangeiros e diferenças na trajetória de aperfeiçoamento competitivo.

Mytelka (2000, p. 28) conclui que em contraste com o processo quase autônomo de aprender através da ação, o chamado aprender a aprender é um processo consciente, na ausência do qual as empresas nem aperfeiçoam sua produtividade e nem desenvolvem a capacidade para inovar em produtos e processos à medida que as condições competitivas se alteram. Neste aspecto, as ligações que as empresas estabelecem com clientes e fornecedores no seu mercado doméstico e no exterior, podem ser críticas. As empresas que aprenderam a aprender durante a fase em que lutam para se igualar aos concorrentes estão mais capacitadas a se manterem competitivas através da inovação no longo prazo.

Hamel e Prahalad (1989, p. 63) argumentam que apenas avaliar as atuais vantagens táticas dos concorrentes conhecidos não é o suficiente para entender a determinação e a inventividade dos concorrentes em potencial. As empresas que se destacaram na competição global, sem variação, iniciaram com ambições que estavam fora de proporção com seus recursos e capacitações. Esta obsessão em evoluir foi chamada de intento estratégico. (HAMEL e PRAHALAD, 1989, p. 64-69).

\section{3 - Governança nas cadeias}

Humphrey e Schmitz (2002, p. 20) definem governança econômica como a coordenação de atividades (econômicas) através de relações que não são de mercado.

De acordo com Humphrey e Schmitz (2002, p. 4-5), o conceito de governança é central à abordagem de cadeia global de valor. O termo governança é utilizado para expressar que algumas empresas na cadeia definem ou determinam que outras sigam seus parâmetros operacionais. Uma cadeia de valor sem governança é apenas um amontoado de relações de mercado.

O conceito de governança está ligado às relações entre empresas e mecanismos institucionais através dos quais se obtém a coordenação de atividades na cadeia, sem que esta seja realizada pelo mercado. 
Williamson (1975, p. 20) assume que inicialmente as transações eram de mercado. Contudo, devido às falhas, emergiram outras formas de coordenação.

Também Humphrey e Schmitz (2004, p. 349) enfatizam que o foco de sua abordagem no tema governança não implica que outros fatores percam importância para a ocorrência do aperfeiçoamento competitivo. A proposta é que as oportunidades de aperfeiçoamento competitivo são, com freqüência, estruturadas pelos relacionamentos nas cadeias globais de valor.

Gereffi (1994, p. 97-100) nota que a estrutura de governança das GVCs, embora essencial para a coordenação dos sistemas internacionais de produção, até aquele momento havia recebido menos atenção do que deveria. Dois perfis de cadeias, distintos quanto à governança, foram caracterizados: (1) Cadeias governadas (comandadas) pelos produtores. Aqui as grandes empresas multinacionais, normalmente industriais, desempenham um papel central no controle do sistema produtivo. É mais característica de setores intensivos em capital, como automóveis, computadores, aviões etc. (2) Cadeias governadas pelos compradores. Grandes varejistas e empresas conhecidas como trading companies desempenham o papel principal. Estas redes são descentralizadas, com as empresas produtoras normalmente localizadas nos países em desenvolvimento. Este tipo de cadeia ocorre com mais freqüência em setores de produtos de consumo, intensivos em mão-de-obra, como, por exemplo, roupas, calçados, móveis, enfeites etc. A produção sob contrato, do tipo OEM, é mais freqüente. As empresas que comandam cadeias com este perfil normalmente não contam com suas próprias instalações manufatureiras. Estas empresas governadoras das cadeias são empresas comerciais que dominam competências como design e marketing. A principal atividade destas empresas que governam as cadeias com este perfil é a gestão destas redes de produção e comércio. A renda superior neste tipo de cadeia não é resultado de economias de escala ou avanços tecnológicos, como ocorre nas cadeias governadas pelos produtores. A renda superior resulta de uma combinação inigualável de pesquisa de alto valor, design, competências de marketing e serviços financeiros.

Contudo, Gibbon e Ponte (2005, p. 80 e 84) observam que nos últimos anos da década de 1990, foi constatado que, algumas GVCs tendiam a se movimentar de uma classificação para a outra. Também é notado que esta classificação de Gereffi (1994) não exclui a possibilidade de que seja registrada uma gradação de poder entre as duas classificações. 
Também Gibbon e Ponte (2005, p. 200) concluem que, das seis GVCs examinadas a partir da perspectiva de empresas africanas, com exceção de uma delas, todas as demais se tornaram em maior grau governadas pelos compradores. O perfil dos compradores que governa estas cadeias varia. A exceção a esta tendência está na cadeia do algodão, onde não foi possível identificar um grupo claro de empresas que governa a cadeia. Em seguida às empresas líderes destas cadeias, há outros participantes poderosos, que são os fornecedores de primeiro nível. Estas empresas desempenham o trabalho cotidiano da coordenação das cadeias para as empresas líderes.

Gibbon e Ponte (2005, p. 77) notam que os estudos sobre as GVCs na década de 1990 passaram a incluir uma atividade fundamental que á a coordenação das atividades produtivas, chamada de governança. Além da governança de todo o processo, foram incluídas outras atividades além da manufatura, como atividades de design, de distribuição e demais pertencentes ao marketing e de apoio ao comprador final. O conceito de cadeia global de valor se refere à configuração de atividades coordenadas, que são divididas entre empresas e que têm uma escala geográfica global.

Humphrey e Schmitz (2004, p. 96-97) usam o termo governança da cadeia para caracterizar situações em que algumas das empresas que dela participam, determinam os parâmetros sob os quais os outros participantes operam. Há variadas formas de exercer a governança, sendo que partes diferentes da mesma cadeia podem ser governadas de formas diferentes. A questão da governança na cadeia emerge quando algumas empresas trabalham de maneira a atender a parâmetros definidos por terceiros. Quando isto ocorre, há necessidade das estruturas de governança para transmitir informação a respeito destes parâmetros e garantir a adesão aos mesmos. Em resumo, governança se refere às relações entre empresas e mecanismos institucionais através dos quais se obtém a coordenação das atividades. Nem sempre a governança ocorre nas cadeias de valor. Muitos produtos são transacionados nos mercados através de uma série de transações de mercado entre as empresas. Nestas circunstâncias, não ocorre este ajuste mútuo das atividades do comprador e do vendedor para atender às solicitações de clientes específicos. Este tipo de relacionamento acontece em mercados com alta fragmentação de compradores e vendedores, e também em mercados em que, uma grande empresa vende produtos padronizados utilizados por muitos compradores de pequeno porte. 
Há muitas formas onde a relação entre as empresas pode fugir deste padrão de não ocorrência do ajuste mútuo de atividades. Uma das formas é aquela na qual a produção é feita sob encomenda, ao invés de simplesmente seguir as previsões do vendedor. Neste caso, as decisões sobre tempo de entrega e quantidades a serem produzidas serão feitas em conjunto pelo comprador e pelo vendedor. Uma situação típica é aquela em que o produto tem muitas versões possíveis, o que torna a produção de acordo com previsões realizadas pelo vendedor não viável economicamente.

Williamson (1975, p. 94 e 107) argumenta que os contratos, independente de quão completos, enfrentam dificuldades. Com relação à duração, também são apontados problemas existentes em variadas situações. Há concordância com a avaliação que os contratos entre as empresas são, na verdade, muito mais informais, e também menos completos, do que se supõe. No mundo acadêmico, legal e da gestão existem diferentes atitudes com relação a contratos. Aliás, Williamson (2002, p. 174) adiciona a esta noção a afirmativa de que todos os contratos complexos são inevitavelmente incompletos.

Dolan e Humphrey (2000, p. 170) concluem que uma cadeia global de valor não é meramente um fluxo de produtos que circula através de fronteiras nacionais. Elas consistem de redes nas quais aqueles que decidem influenciam o produto da cadeia e sua distribuição.

Kaplinsky e Morris (2003, p. 29) consideram que cadeias de valor implicam a repetição na interação (entre empresas). A governança garante que as interações entre as empresas ao longo da cadeia de valor reflitam alguma forma de organização, ao invés de serem aleatórias. A assimetria de poder é central ao conceito de governança da cadeia de valor.

Cooke e Morgan (1998, p. 59) concluem que a assimetria em uma relação de poder não exclui a possibilidade de colaboração. Também não sugerem que, a despeito da assimetria, os benefícios sejam simetricamente distribuídos. Nas parcerias em cadeias de valor, o comprador seria o elo dominante, de forma que obtém benefícios dos mercados e hierarquia sem os custos.

Palpacuer (2000, p. 373 e 376) elabora sobre o racional para as relações de poder nas redes produtivas. A empresa líder provê a alocação eficiente dos recursos, a visão global e a velocidade decisória que são necessárias para construir e manter a vantagem competitiva da 
rede. As empresas líderes são uma alavanca importante neste processo, pois utilizam um misto de cooperação e ligações de mercado para aperfeiçoar a vantagem competitiva que advém de redes produtivas.

Gibbon e Ponte (2005, p. 204) apontam que as empresas líderes podem recorrer a diferentes estratégias para manter sua posição. Nem sempre estas estratégias aderem ao objetivo de externalizar um número crescente de funções. As estratégias específicas que as empresas líderes adotam dependem de vários fatores, contudo, fica claro que a governança dos compradores é cada vez mais exercida à distância, isto é sem que ocorra o envolvimento operacional direto da empresa líder nesta atividade. O relato é que no pós-guerra, as empresas líderes preferiam formas diretas de coordenação com seus principais fornecedores. Esta coordenação direta assumia não só a forma de integração vertical, mas densas relações sociais e contratuais, muitas vezes exclusivas, com este perfil de fornecedor. Mais recentemente, as empresas líderes elaboraram formas diferentes de coordenação, nas quais há menor envolvimento direto. Esta tendência surgiu em linha com a emergência de uma categoria de fornecedores de primeiro nível responsáveis por esta atividade. Esta categoria de fornecedores é estimulada a assumir um número crescente de funções, o que inclui a parte operacional da coordenação de outros níveis da cadeia. Desta forma, as empresas líderes governam uma cadeia sem, de fato, controlá-la diretamente, ou mesmo sem possuir as capacitações funcionais para fazê-lo.

Rugman e D’Cruz (2000, p. 62) acreditam que a assimetria de poder, onde a empresa líder governa, há mais eficácia quanto à direção estratégica da rede. As implicações da assimetria são percebidas no nível de confiança (entre as empresas), estabilidade (da cadeia) e desenvolvimento do conhecimento (também da cadeia).

Kaplinsky (2000, p. 124-126) complementa a definição de Gereffi (1994) ao explicar que há participantes fundamentais na cadeia, que assumem a responsabilidade pela divisão do trabalho entre as formas e pela capacidade de membros específicos de aperfeiçoarem suas atividades. Governança é importante devido à natureza do comércio na era recente de globalização. A diferença fundamental é que ao final do século XX, o comércio é cada vez mais de sub-componentes e serviços, portanto tornando-se consideravelmente mais complexo. Em um período anterior, o comércio ocorria principalmente na forma de um relacionamento 
de mercado. Os produtos finais eram, em grande parte, fabricados em um país específico e então exportados.

O comércio na era da globalização, devido a sua complexidade e relações igualmente complexas que contém, exige formas sofisticadas de coordenação. Isto corre não somente com relação à logística, mas também com relação à integração dos componentes no design do produto final e com relação aos padrões de qualidade com que se alcança a integração. O ato de governança reflete os papéis de coordenação (principal) e de identificação de oportunidades dinâmicas (complementar) de obtenção de renda, além da distribuição de papéis a serem desempenhados pelos principais atores do processo.

Dolan e Humphrey (2000, p. 150-151) questionam as razões da existência de governança. O questionamento está relacionado às razões pelas quais os compradores internacionais não utilizam relacionamentos pontuais, de mercado. Estes, não exigem altos investimentos em governança e trazem maior flexibilidade de alternativas de fornecimento. São indicadas duas as razões pelas quais as GVCs devem ser governadas: (1) O aumento de estratégias de diferenciação de produto nos mercados desenvolvidos. A vantagem competitiva das empresas está na comercialização de produtos diferenciados, não disponíveis no mercado. A competitividade das organizações depende de outros fatores além do preço, como por exemplo, confiabilidade, variedade e qualidade do produto e velocidade da inovação. Esta estratégia competitiva aumentaria a necessidade de governança na cadeia de fornecimento. (2) A necessidade de governança aumenta nas ocasiões em que os produtores dos países em desenvolvimento têm dificuldade em atender às exigências dos mercados dos países desenvolvidos.

Por si estas duas razões não criam a necessidade de gestão intensa da cadeia. Contudo, a governança é necessária nas ocasiões em que ao fornecedor falta competência técnica ou conhecimento do mercado.

Sturgeon (2000, p. 11) nota três estilos de governança que desempenham papéis importantes na reorganização e realocação das empresas hoje: (1) a chamada governança autoritária ou, como pode ser também rotulada, rede de produção exclusiva; (2) a rede produtiva relacional e (3) a rede produtiva virtual. O quadro 7 que segue detalha estes três estilos de governança. 
Quadro 7 - Tipos de governança em Cadeias de valor / Redes produtivas

\begin{tabular}{|c|c|c|c|}
\hline $\begin{array}{c}\text { NOME } \\
\text { DA REDE }\end{array}$ & $\begin{array}{c}\text { BASE DA } \\
\text { AUTORIDADE }\end{array}$ & OUTROS NOMES & EXEMPLOS \\
\hline $\begin{array}{l}\text { 1. Redes baseadas } \\
\text { na autoridade } \\
1.1 \text { - Redes intra- } \\
\text { firma }\end{array}$ & $\begin{array}{l}\text { - Rede } \\
\text { - Autoridade do gestor (ou da } \\
\text { gestão) }\end{array}$ & $\begin{array}{l}\text { - Governança } \\
\text { - Integração vertical } \\
\text { - Cadeias governadas pelos } \\
\text { produtores mercadorias (producer- } \\
\text { driven commodity chains) }\end{array}$ & $\begin{array}{l}\text { - “Velha” IBM } \\
\text { - Grupo Toyota } \\
\text { - Kairetsus } \\
\text { japoneses } \\
\text { - Chaebol } \\
\text { coreanos }\end{array}$ \\
\hline $\begin{array}{l}1.2 \text { - Redes } \\
\text { exclusivas }\end{array}$ & $\begin{array}{l}\text { - Autoridade da empresa líder } \\
\text { - Relações de longo prazo }\end{array}$ & $\begin{array}{l}\text { - Grupos industriais } \\
\text { - Redes enxutas de produção }\end{array}$ & \\
\hline $\begin{array}{l}\text { 2. Redes } \\
\text { relacionais }\end{array}$ & $\begin{array}{l}\text { - Personalistas de longo prazo } \\
\text { e relações entre empresas } \\
\text { - Assumem características de } \\
\text { grupo }\end{array}$ & $\begin{array}{l}\text { - Redes baseadas na confiança } \\
\text { - Redes personalistas } \\
\text { - Redes que envolvem transações } \\
\text { que se repetem }\end{array}$ & \\
\hline $\begin{array}{l}2.1 \text { - Redes em } \\
\text { aglomerados }\end{array}$ & - Proximidade espacial & $\begin{array}{l}\text { - Distritos industriais } \\
\text { - Pólos industriais }\end{array}$ & $\begin{array}{l}\text { - Vale do Silício } \\
\text { - } 3^{\text {a }} \text { Itália } \\
\text { - Distrito } \\
\text { confeccionista } \\
\text { em Nova Iorque, } \\
\text { EUA }\end{array}$ \\
\hline 2.2 - Redes sociais & - Proximidade social & $\begin{array}{l}\text { - Redes étnicas } \\
\text { - Grupos de interesse } \\
\text { - Redes culturais }\end{array}$ & $\begin{array}{l}\text { - Diáspora } \\
\text { chinesa } \\
\text { - Máfia }\end{array}$ \\
\hline 3. Redes virtuais & $\begin{array}{l}\text { - Economias externas de } \\
\text { escala } \\
\text { - "Promiscuidade” de atores da } \\
\text { rede } \\
\text { - Capacidade da rede } \\
\text { "commoditizada” } \\
\text { - Transferência de } \\
\text { especificações codificável }\end{array}$ & $\begin{array}{l}\text { - Redes de produção turn-key } \\
\text { - Redes produtivas ágeis } \\
\text { - Cadeias governadas pelos } \\
\text { compradores (buyer-driven } \\
\text { commodity chains) }\end{array}$ & $\begin{array}{l}\text { - Cisco e } \\
\text { Solectron } \\
\text { - Comércio B2B } \\
\text { - “Nova” IBM } \\
\text { - Vale do Silício } \\
\text { e suas relações } \\
\text { externas }\end{array}$ \\
\hline
\end{tabular}

FONTE: STURGEON, 2000, p. 15.

Conforme Humphrey e Schmitz (2000, p. 25-26), operar em uma cadeia cuja governança está baseada em uma rede é o cenário mais desejável e ao mesmo tempo o menos provável para a maioria das empresas de países emergentes. É desejável porque, como uma considerável parte da literatura enfatiza, a inovação resulta de processos interativos entre produtores e usuários. Há três razões pelas quais organizações de países emergentes possuem menor chance de operar em cadeias caracterizadas pela transmissão da inovação e por relações do tipo rede.

Primeiro, Humphrey e Schmitz (2000, p. 26-27) aderem à explicação de que o escopo do 
aprendizado por interação é muito maior na fase introdutória do ciclo de vida do produto (CVP), do que na fase madura. As exportações dos países emergentes são tipicamente de produtos que se encontram na fase da maturidade do Ciclo de Vida do Produto (CVP). A segunda razão pelas quais estas relações são raras é o diferencial em termos de competência que existe entre compradores e vendedores. A terceira razão diz respeito à fragilidade destas relações do tipo rede. Embora esta terceira razão seja controversa, pois as redes são, com freqüência, associadas com relações duradouras e estáveis.

Bazan e Navas-Alemán (2004, p. 111) observam que dependendo do comprador, a cadeia exibe diferentes características de governança. Nos EUA, a conclusão foi que, nas cadeias pesquisadas, o aperfeiçoamento competitivo de produto e processo é comum, em comparação ao funcional, que é raro. A governança na Europa é menos hierárquica e o aperfeiçoamento competitivo funcional ligeiramente mais comum. Também foram caracterizadas nos mesmos setores investigados, as cadeias nacionais, que objetivam atender o mercado brasileiro. A governança destas cadeias é caracterizada por relações de mercado e o aperfeiçoamento competitivo disseminado. As cadeias latino-americanas apresentam características híbridas: quasi-hierarquia e mercado. Há casos em que a governança da cadeia de valor doméstica é completamente diferente do que ocorre na cadeia global do mesmo setor (BAZAN; NAVASALEMÁN, 2004, p. 116).

Outra colocação relacionada à influência da governança no desempenho das empresas está relacionada ao aperfeiçoamento competitivo das empresas brasileiras dos setores estudados nas cadeias nacionais. Diferente do que ocorre nas cadeias globais, onde a governança é caracterizada pela quasi-hierarquia, nas cadeias nacionais predomina o mercado. Nesta última situação, florescem as competências para o aperfeiçoamento competitivo funcional; nas cadeias globais, sob governança quasi-hierárquica só ocorre o aperfeiçoamento de produto e de processo. (BAZAN; NAVAS-ALEMÁN, 2004, p. 126).

Humphrey e Schmitz (2004, p. 99-101) notam que a determinação de parâmetros é onerosa para o comprador, visto que exige investimentos ativo-específicos em relações com fornecedores pontuais. Estes investimentos também aumentam a rigidez da cadeia, pois cresce o custo de se mudar de fornecedor. As empresas estariam dispostas a incorrer nestes custos em situações particulares. Uma destas situações é aquela em que os produtos são diferenciados, pois produtos homogêneos podem ser comercializados através de transações de 
mercado. Portanto, uma das razões para que seja necessária a governança está na arquitetura do produto. Nas situações em que a arquitetura do produto é integral, ou seja uma alteração em uma parte do produto causa alterações em muitas outras partes, o comprador tem que coordenar as decisões de vários fornecedores. Produtos cuja arquitetura é modular, ou seja, há poucas interfaces entre as partes e elas são bem definidas fazem com que alterações em uma parte do produto não ocasionam mudanças em outras partes. A necessidade de governança aumenta quando alterações têm implicações em atividades que ocorrem em estágios anteriores da cadeia de valor. A governança na cadeia de valor pode emergir de duas tendências distintas: (1) A tendência de aumento da terceirização de atividades antes realizadas pela própria empresa significa que a coordenação interna é substituída pela governança na cadeia. (2) A diferenciação de produtos e a coordenação relacionada à padronização dos processos, que leva a crescente coordenação de atividades, antes conduzidas fora através de relações de mercado.

A sugestão de Humphrey e Schmitz (2004, p. 352-353) é que as relações quasi-hierárquicas de governança da rede ocorrem nos arranjos em que o comprador necessita determinar com precisão as características do produto ou avalia estar exposto a considerável risco do fornecedor não desempenhar a contento.

Porter e Wayland (1995, p. 65) resumem a razão pela qual a forma multinacional emergiu, remetendo à governança: ativos intangíveis como know how e marca não podem ser facilmente comercializados através de fronteiras em transações de mercado, devido aos altos custos de transação.

Palpacuer (2000, p. 377) nota a importância do conceito de empresas líderes. Em várias situações em países diferentes como Itália, Japão e EUA, as empresas líderes apresentaram algumas características em comum: suas competências fundamentais estão baseadas em marketing, desenvolvimento de produtos, em algumas atividades estratégicas ligadas à produção, bem como na coordenação de relações entre empresas dentro da cadeia de valor.

A importância do conceito de empresas líderes também é notada por Pietrobelli (1998, p. 6), visto que os exportadores dos países em desenvolvimento, raramente, seriam líderes de mercado, exceto por situações isoladas em nichos específicos. O mais comum é que as 
empresas dos países em desenvolvimento simplesmente atuem sob a governança das empresas dos países desenvolvidos, que logram impor suas exigências.

Rugman e D’Cruz (2000, p. 84-85 e 187) apresentam uma definição operacional de empresa líder: trata-se da entidade que provê liderança estratégica e direção para a rede empresarial integrada verticalmente, que opera como uma rede ou sistema coordenado. Freqüentemente ocorre a competição com redes similares, que têm como foco os mesmos mercados finais. Esta definição significa que a empresa líder exerce controle sobre a estratégia dos seus parceiros da rede, sem que haja reciprocidade nesta influência. Uma característica principal destas relação é o seu foco colaborativo, em comparação a um foco competitivo.

A forma de organização que contempla as empresas líderes está se provando eficaz no desenvolvimento da competitividade global em uma variedade de setores. Um dos exemplos citados diz respeito à instituição financeira, que decidiu terceirizar a operação de seus sistemas de Tecnologia da Informação. Os fornecedores externos são utilizados para operar, manter e expandir a infra-estrutura de equipamentos. Os funcionários do banco são em número mínimo e estão envolvidos somente com a gestão do processo. A instituição citada estaria indo ao encontro ao que muitas outras instituições financeiras estão fazendo, pois insistem que seu negócio é informação.

Gibbon e Ponte (2005, p. 99) afirmam que o termo empresa líder não se refere principalmente à participação de mercado destas empresas, em comparação com outras na mesma posição funcional. O fato principal é que as empresas líderes, como categoria, controlam certas funções na cadeia, que lhes permite ditar os termos da participação de outros atores em diferentes posições funcionais.

Humphrey e Schmitz (2002, p. 24-27) distinguem quatro maneiras através das quais as relações entre atividades em uma cadeia de valor podem ser gerenciadas: (1) Relações de mercado. Comprador e fornecedor não desenvolvem relações próximas; (2) Redes. Firmas de convivência próxima e recíproca; (3) Quasi-hierarquia. Uma firma exerce um alto grau de controle sobre outras firmas. Ocorre nas circunstâncias em que há dúvida sobre a competência do fornecedor; e (4) Hierarquia. A empresa líder é proprietária direta das operações na cadeia. A explicação é que emergem diferentes tipos de governança quando é necessária a coordenação de atividades que não seja aquela através do mercado. Neste caso, os agentes em 
um ponto da cadeia determinam os parâmetros seguidos pelos agentes em um ou mais pontos da cadeia. Gereffi et al (2005, p. 86) adicionam entre mercado e hierarquia a noção de governança relacional, caracterizada pela troca de informação não codificada.

Williamson (1991A, p. 269) também se refere às diferentes formas de coordenação das transações - através do mercado, híbrida e hierarquia - e argumenta que as além de distintos mecanismos de coordenação e controle, estas diferentes formas têm capacidade desigual de adaptação a distúrbios. Outro argumento colocado é a hierarquia seria apenas a continuação da coordenação através do mercado, com outros meios. (WILLIAMSON, 1991A, p. 271). Na situações em que é necessária uma adaptação coordenada, comparativamente as outras formas, a governança através da hierarquia seria a preferida. (WILLIAMSON, 1991B, p. 80).

Barney (1986, p. 796-797) também enfatiza a importância da capacidade de adaptação a distúrbios, principalmente nas empresas que atuam em setores marcados por rápidas transformações. Contudo, estas transformações não podem ser antecipadas com precisão pelas empresas.

Williamson (1985, p. 72-74) propõe que: (1) Transações altamente padronizadas não necessitam de uma estrutura de governança especializada. (2) Somente transações que se repetem suportam uma estrutura de governança especializada. (3) Ainda que as transações ocasionais, do tipo não padronizado, não suportem uma estrutura específica de governança, elas merecem atenção especial.

A governança de mercado seria a principal para transações não específicas, sejam ocasionais ou repetitivas. Os mercados são especialmente eficientes quando se contempla transações repetitivas. A razão é que as partes envolvidas somente precisam consultar sua própria experiência para a decisão de continuar ou não a relação comercial. O custo transacional de mudar é relativamente baixo.

Em transações que não são específicas e que ocorrem ocasionalmente, as partes são menos capazes de se fiar na experiência para garantir que sejam eficientes. A especificidade das transações é relacionada ás formas de governança. (WILLIAMSON, 1985, p. 74-78). 
Williamson (1985, p. 90) trata ainda das principais diferenças relacionadas às formas de governança pelo mercado e através da organização interna: (1) Os mercados promovem incentivos poderosos e limitam as distorções da burocracia com maior eficácia do que a organização interna. (2) Os mercados, algumas vezes, podem realizar economias de escala através da agregação de demandas. (3) A organização interna tem a capacidade de acessar instrumentos de governança específicos.

Finalmente, Williamson (1996, p. 101) ao investigar em que atributos, principalmente, as estruturas de governança se diferenciam, indica que, além das distinções legais, o crucial se refere à adaptabilidade e à utilização de instrumentos de incentivo e controle. Com relação à adaptabilidade, uma vantagem da hierarquia em relação às formas híbridas de governança, está no fato de que os contratos podem ser mais incompletos. (WILLIAMSON, 1991A, p. 280). Contudo, Williamson (2002, p. 175) pontua que cada modo de governança possui vantagens e fragilidades, se distinguindo em seus respectivos custos e competências. Concorda-se que uma das vantagens da coordenação através do mercado é a possibilidade dos atores decidirem corretamente com pouca informação.

Com relação à integração, seja vertical ou lateralmente, estas são para serem empregadas quando tudo o mais falha. (WILLIAMSON, 1996, p. 101). Rugman e D’Cruz (2000, p. 8990) apresentam as falhas da integração vertical: (1) Uma motivação importante para evitar a integração vertical é a captura de renda por grupos de funcionários em uma unidade à montante ou à jusante ou pelo grupo de funcionários da alta administração. (2) Os segundos tipos de falha são àquelas relacionadas à gestão.

Williamson (1996, p. 145) chama a governança através do mercado de espontânea, em contrapartida as outras formas, que são intencionais. Williamson (2002, p. 178) também lembra que a abordagem da governança argumenta que a razão de ser destas estruturas é minimizar o custo de transação.

Humphrey e Schmitz (2004, p. 362-363) elaboram mais sobre a governança do tipo rede, que envolve um compromisso mútuo mais forte do que a relação de mercado. A diferença para a relação de mercado é que na governança do tipo rede, há menos assimetria. Estas relações emergem nos casos em que há competências complementares entre as organizações, em uma medida em que ambas podem contribuir para a inovação. Uma das conclusões é que a 
governança do tipo rede não surge no estágio inicial do ciclo do produto, quando há intensa interação entre produtores e usuários. Embora estas redes sejam mais usuais nos países desenvolvidos, as empresas dos países em desenvolvimento podem desenvolver relações do tipo rede com seus clientes. Neste caso, a forma mais provável é uma rede modular de produção.

Kaplinsky (2000, p. 140) conclui que as relações de mercado estão sendo crescentemente confinadas às mercadorias (commodities) que trazem baixas rendas. Acesso às atividades que propiciam altas rendas exige a participação (por parte das empresas) nas GVCs. Portanto, o desafio fundamental é identificar formas nas quais, as empresas de países pobres, possam entrar nestas cadeias e participar delas de uma forma que possa levar a um acréscimo sustentável na sua renda.

Humphrey e Schmitz (2002, p. 24-27) explicam que a principal razão para especificação dos parâmetros ao longo da cadeia é a limitação do risco. Os riscos de desempenho relacionados a fatores como qualidade, tempo de resposta e confiabilidade da entrega se tornam mais importantes quando as empresas se envolvem em situações competitivas que envolvem outros fatores que não o preço. Os riscos de desempenho também aumentam à medida que os produtores dos países em desenvolvimento se defrontam com padrões de complexidade crescente, relacionados ao produto a ao processo produtivo, que são exigidos para os produtos comercializados nos países industrializados. É reconhecido que nem toda determinação de parâmetros ao longo da cadeia resulta em sua governança. Contudo, a determinação de parâmetros é freqüentemente alcançada através do desenvolvimento das estruturas de governança nas cadeias de valor. Estruturas de governança permitem que se determinem os padrões e se exija o seu cumprimento.

Humphrey e Schmitz (2000, p. 28) enfatizam que é importante o reconhecimento do intento estratégico como um determinante do aperfeiçoamento local. O aperfeiçoamento local de algumas empresas na parte Leste do continente asiático pode se dever ao seu intento estratégico, ou seja ao seu esforço consciente para aprender e sua disposição para realizar os investimentos que são necessários para isto. Estes investimentos ocorrem dentro das próprias empresas e também no relacionamento com outras empresas (intra-firma e inter-firmas). Humphrey e Schmitz (2000, p. 28) concordam com os que relacionam este intento estratégico, tão notável no leste da Ásia a um ambiente e políticas públicas que o apóiam. Alterações 
freqüentes e drásticas na estrutura de incentivos fazem com que seja difícil desenvolver ou manter a intenção estratégica de aperfeiçoamento competitivo.

Humphrey e Schmitz (2000, p. 17) argumentam que a necessidade de governança nas cadeias globais diminui à medida que a capacitação de entregar dos fornecedores locais se desenvolve e se difundem. Bazan e Navas-Alemán (2001, p. 63) no estudo do cluster calçadista do Vale dos Sinos, Brasil concluem que a análise da governança das cadeias deve ser multifacetada. A governança pode ser exercida através das seguintes dimensões: dependência de mercado, poder simbólico, concentração de conhecimento, concentração de vendas, dependência de canais de vendas e poder agregador.

Dedrick e Kraemer (1998, p. 220-221) ao estudarem o setor de informática na Ásia chegaram a algumas conclusões. Uma delas está relacionada à estrutura do setor no mundo, baseada em um conjunto complexo de relacionamentos, onde as empresas interagem como compradores, vendedores, concorrentes e parceiros estratégicos. As empresas de maior êxito têm relacionamentos flexíveis com outras empresas, os quais são adaptados às novas condições conjunturais ao longo do tempo. As empresas precisam ser capazes de interagir de diferentes formas, sob circunstâncias distintas. Estas interações, no setor de informática nos EUA, são operacionalizadas através de transações comerciais de mercado, relações de cooperação informais, ou ainda alianças formais e empreendimentos desenvolvidos em conjunto com outras organizações. Nas redes globais ocorre o mesmo. Um país está integrado de forma mais eficaz quando tem múltiplas ligações com a rede global. O aumento da eficácia ocorre nas situações em que as empresas locais têm relações com muitas multinacionais ou vendem diretamente aos mercados estrangeiros. Ligações fortes com o sistema produtivo global rendem muitas recompensas às empresas locais.

O conceito de governança utilizado neste trabalho está definido no Capítulo 1: é adicionada à definição de Williamson (1985, p. 68) a questão da distribuição dos resultados, que está por sua vez ligada à obtenção de poder na cadeia. Esta definição é operacionalizada conforme segue. Há governança na cadeia se: (1) Há produção sob encomenda de uma das partes. (2) Há contrato entre as empresas, ou seja, a relação não é de mercado. (3) As interações refletem alguma forma de organização. Quanto à questão do poder, este existe se uma das partes determina parâmetros. 


\section{4 - Renda econômica}

Schoemaker (1990, p. 1179-1181), embora note que não existe convergência na literatura sobre o significado preciso do termo renda econômica, propõe a conceituação que segue na ilustração 6, dos fatores mais importantes para determinar a criação de renda e sua distribuição.

\section{Ilustração 6 - Fatores estratégicos para o aumento da renda}

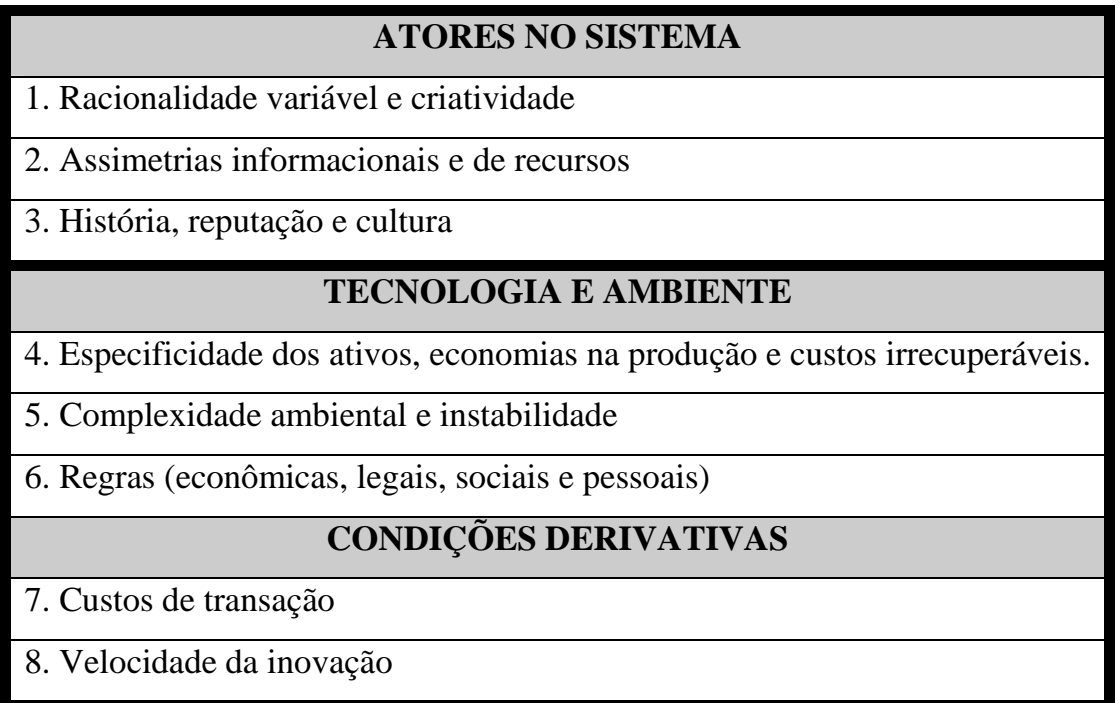

FONTE: SCHOEMAKER, 1990, p. 1182.

Estas características sistêmicas e dos atores dão origem a numerosas características secundárias como os custos de transação e a velocidade das inovações de produto, mercado e organizacionais. Fatores como história e instabilidade têm sido relativamente ignorados na chamada nova micro-economia. (SCHOEMAKER, 1990, p. 1181).

As empresas, além do desafio de se posicionar no ambiente para obter renda econômica superior, devem mantê-los. (SCHOEMAKER, 1990, p. 1188). Amit e Schoemaker (1993, p. 33) associam o desenvolvimento de vantagem competitiva por parte da empresa à obtenção de rendas superiores.

Amit e Schoemaker (1993, p. 38) propõem o esquema que segue na ilustração 7 para resumir os principais determinantes de rendas superiores na empresa. 


\section{Ilustração 7 - Características desejáveis dos recursos e capacitações da empresa (para geração de renda econômica superior)}

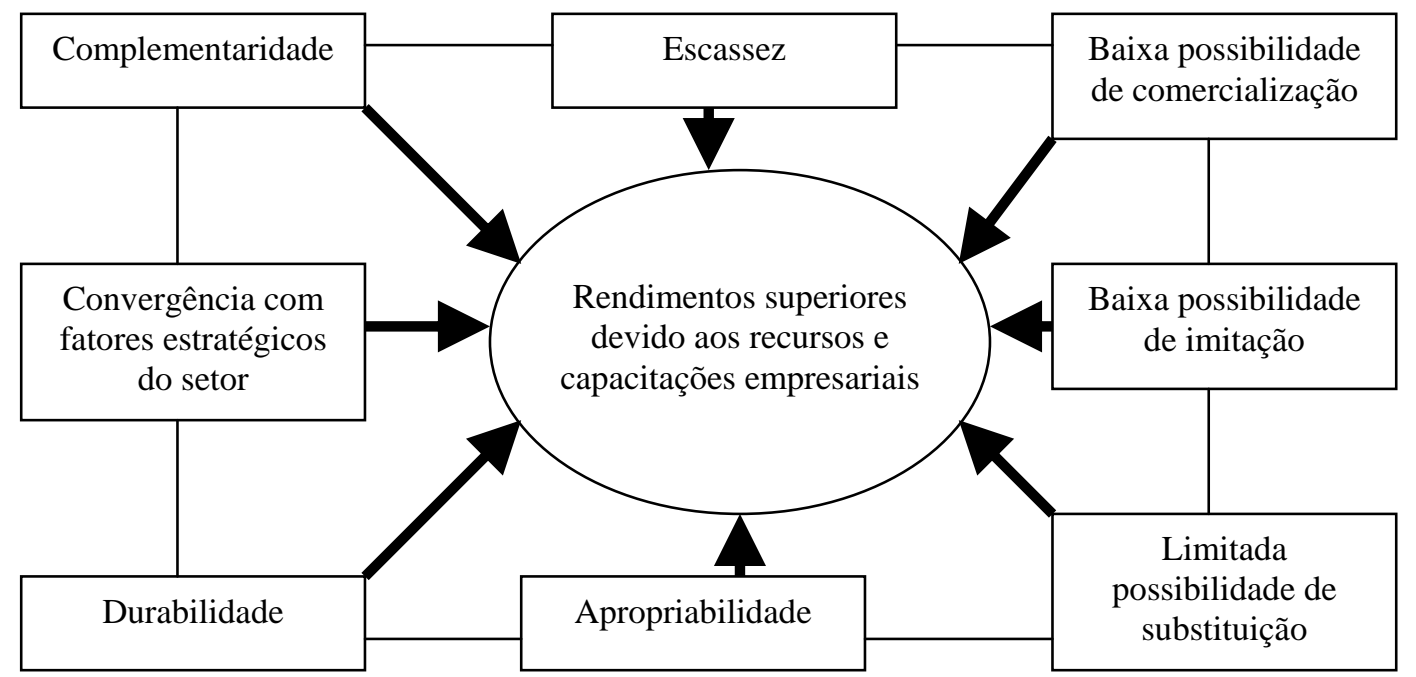

FONTE: AMIT; SCHOEMAKER, 1993, p. 38.

Teece et al (1997, p. 511-512) expõem que uma empresa em um determinado setor pode obter rendas superiores quando logra impedir que as forças competitivas que as fazem tender a zero, atuem. Também é notada a importância do aspecto empreendedor da estratégia, relacionado à criação e proteção de novos fluxos de rendas.

Kaplinsky (2005, p. 62-65) observa que a renda advém da escassez. Isto significa a posse de algo - um recurso, capacitação, conhecimento - que outros não possuem. Para durar, a renda precisa ser protegida por barreiras à entrada. Algumas destas rendas e barreiras à entrada são endógenas à cadeia produtiva; isto é são construídas pelos próprios produtores de forma independente ou em conjunto com outros produtores. Outras rendas e barreiras à entrada são exógenas ao setor empresarial. São, algumas vezes, originárias da natureza ou, mais provavelmente, geradas por partes externas á cadeia. Estas rendas e barreiras à entrada são acessíveis a alguns seletos produtores, o que lhes traz uma capacidade de gerar e sustentar estes rendas.

É adotada a estrutura analítica schumpeteriana onde a ligação entre inovação e renda superior é encontrada nas barreiras à entrada, que têm o papel de limitar a competição. Quanto maiores as barreiras à entrada, é mais provável que as rendas sejam altas. Portanto, para o produtor, uma pergunta fundamental está relacionada ao grau de insuperabilidade das barreiras à entrada. Portanto, as barreiras à entrada são um componente central da teoria da renda e, da 
mesma forma, esta teoria é fundamental para o entendimento da existência e da sustentabilidade das rendas superiores.

Gibbon e Ponte (2005, p. 16 e 31) observam que a busca por renda oligopolística se transformou no instrumento de gestão mais popular para a melhora de resultados das empresas. Entre as ações mais freqüentes nesta busca estão: (1) Marketing ainda mais agressivo e precificação seletiva para alcançar ou manter a liderança de mercado. (2) Fixação oligopolística de preços, onde as condições competitivas permitem. (3) Exercício do poder de compra junto aos fornecedores. A conclusão é que as economias de escala (re)emergiram como uma fonte fundamental de vantagem competitiva e diferenciação na economia global e é fundamental na obtenção da renda oligopolística.

A conclusão de Gibbon e Ponte (2005, p. 197) é que esta busca por renda oligopolística, junto com o fortalecimento de marcas e mais formas de terceirização de atividades são estratégias empresariais deliberadas.

Teece et al (1997, p. 528-529) notam que a análise da estratégia deve ser situacional. Não há algoritmo disponível para a criação de rendimentos superiores para todo um setor. Receitas recomendadas para setores ou grupos de empresas, na melhor das hipóteses, sugerem uma direção de forma superficial e, da mesma forma, erros que podem ser evitados. Esta seria uma fragilidade do paradigma das forças competitivas, que não é dirigida à empresa, mas a um setor ou grupo. Outra vulnerabilidade deste paradigma está na pouca atenção dada às competências, conhecimento e dependência do passado. A tendência deste paradigma é avaliar que a escolha estratégica ocorra com relativa facilidade.

Peteraf (1993, p. 185-187) argumenta que quatro condições devem existir para que uma empresa obtenha rendas maiores do que seus concorrentes. A heterogeneidade de recursos cria a chamada renda monopolista. Trata-se de uma condição necessária, porém não suficiente para a vantagem competitiva sustentável. Para a renda superior ser sustentável, é necessário que sejam criados limites à competição Ex Post. A heterogeneidade sem limitações à concorrência Ex Post cria vantagens competitivas que são rapidamente imitadas. A limitação Ex Ante à concorrência evita que os custos superem as rendas. Outra condição é a mobilidade imperfeita dos recursos. Finalmente, a produtividade dos recursos superiores depende da forma como são empregados, e como uma estratégia baseada em recursos superiores é 
implementada. O modelo que segue na ilustração 8, pretende explicar as condições em que surge a renda empresarial superior.

\section{Ilustração 8 - Bases da vantagem competitiva}

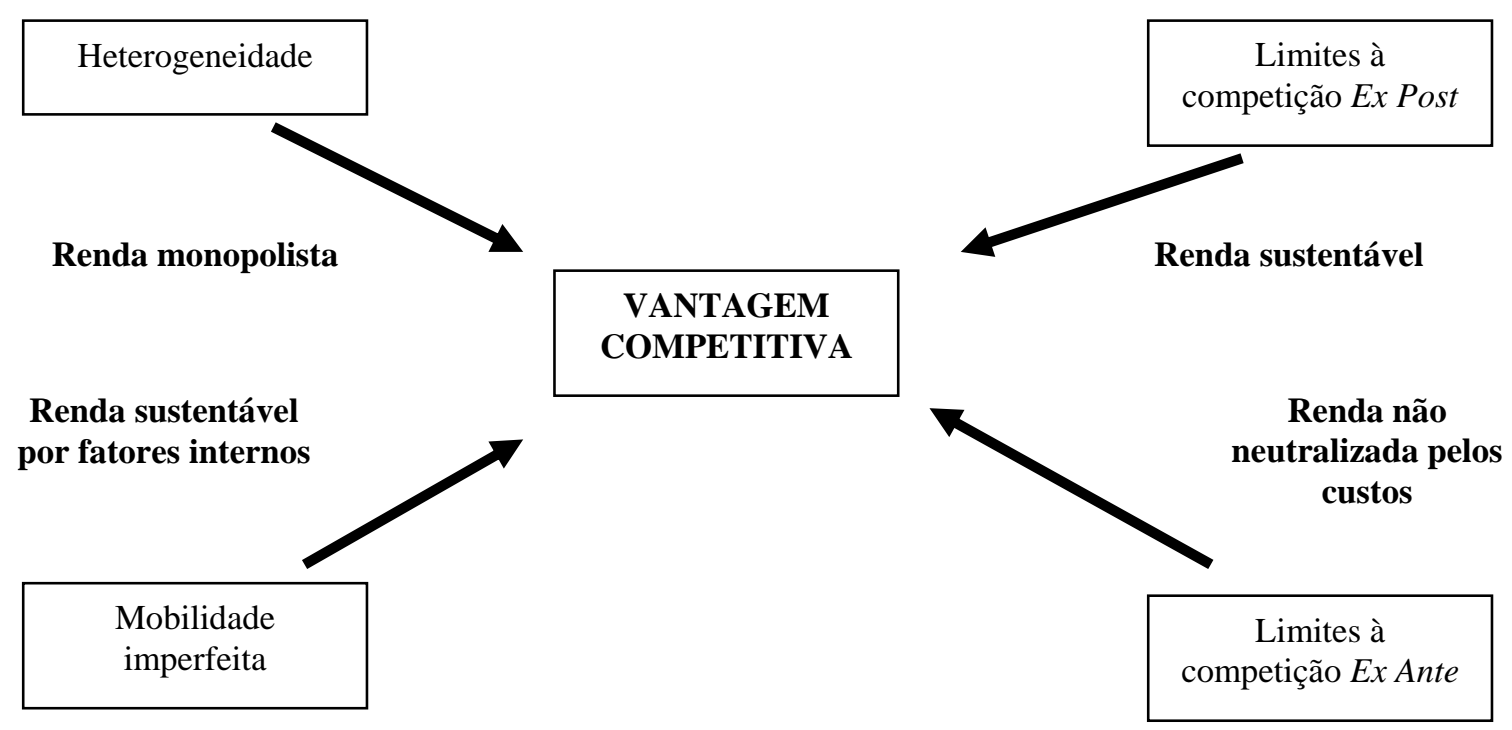

FONTE: PETERAF, 1993, p. 186.

Gibbon e Ponte (2005, p. 151) avaliam que, para certas categorias de produtores de dos países em desenvolvimento, principalmente para os de segundo nível, é proibitivo desenvolver marcas próprias e canais de distribuição, atividades que trazem recompensas maiores. Para os produtores de segundo nível, a forma mais comum de maximizar a renda seria através de uma combinação de vendas diretas aos intermediários e da busca de contratos mais estáveis e do acesso a volumes maiores com clientes diversos.

Maitland e Richard (2007, p. 30) concluem que as empresas precisam se assegurar que fragmentação de cadeias de valor não leva à erosão da renda. O alerta é que decisões, que aparentemente têm pouco significado estratégico, como, por exemplo, o offshoring do design de produtos direcionados para segmentos inferiores ou a formação de empreendimentos conjuntos para a utilização de conhecimento local, podem levar à dissipação de rendimentos no futuro.

Dedrick e Kraemer (1998, p. v - vi e p. 263) concluíram, em estudo sobre o setor de computadores na Ásia, que retornos e renda decrescentes ocorriam para a maior parte dos produtos classificados como commodities. Os produtos que podem ser classificados desta 
forma são principalmente equipamentos (hardware), como, por exemplos, componentes, periféricos e sistemas. Em contraste, retornos e renda crescentes têm ocorrência mais provável nos segmentos baseados em conhecimento do setor, como por exemplo, software, informação e serviços. O desafio para as empresas da Ásia neste contexto seria se movimentar dos segmentos que apresentam renda e retorno decrescente para aqueles com renda e retornos crescentes. Para as empresas dos EUA, o desafio seria manter a liderança em padrões, design, marketing e inovação empresarial.

Outra conclusão é que esta distinção entre os segmentos de mercado que trazem maior renda econômica e aqueles que trazem menor renda econômica no setor de informática é útil, pois auxilia na natureza da competição em segmentos com dinâmicas distintas, bem como sobre as estratégias e capacitações necessárias para o sucesso. É lembrado também que embora esta abordagem dos segmentos com dinâmicas diferentes seja útil para os gestores analisarem conceitualmente seus negócios e suas demandas, na realidade estes segmentos não são assim tão claramente definidos. Algumas empresas têm atividades nos dois perfis de segmentos (de rendas crescentes e de rendas decrescentes). Houve, no caso do estudo em tela, a identificação de vários segmentos de mercado que podem ser classificados como híbridos. Nestes segmentos, as empresas lograram aplicar estratégias de rendas crescentes a segmentos de mercado que aparentavam ser de rendas decrescentes. Uma lição neste caso é que a execução é sempre importante, mesmo em segmentos cujo sucesso é baseado na inovação e podem ser caracterizados como de rendas decrescentes. Outra lição é que há muitas oportunidades para inovação, mesmo nos segmentos caracterizados como de rendas decrescentes. A inovação é o que, com freqüência, separa as empresas que têm êxito daquelas que fracassam.

Kaplinsky e Morris (2003, p. 25-26 e 28) expõem que as rendas de primeira grandeza estão, essencialmente, com aquelas partes que têm capacidade de se proteger da competição. Em resumo, a renda das empresas dependeria dos seguintes fatores: (1) Os aumentos de renda ocorreriam nos casos em que há produtividade diferenciada dos fatores (incluído aí o empreendedorismo). (2) Assume várias formas dentro da empresa, por exemplo, capacitação tecnológica, organizacional, de marketing (uma das dimensões é a gestão de marcas) e competências de modo geral. (3) Também podem surgir de atividades planejadas que ocorrem entre grupos de empresas, tratadas como renda relacional.

Estas diferentes formas de renda econômica são mais precisamente definidas: 
(1) A renda econômica se eleva nos casos em que há produtividade diferencial dos fatores e barreiras à entrada (de competidores).

(2) Há uma variedade de formas de renda econômica que prevalecem na economia global. Algumas formas são endógenas e são criadas pelas empresas. Seguem as definições das diversas formas.

- $\quad$ Rendas derivadas da tecnologia. A empresa domina tecnologias escassas.

- $\quad$ Rendas derivadas da gestão de pessoas. Acesso a profissionais mais capacitados do que a concorrência.

- $\quad$ Rendas derivadas de capacitação organizacional. Posse de formas superiores de organização interna.

- $\quad$ Rendas advindas das atividades de marketing. A empresa é mais capacitada em atividades de marketing e/ou desenvolveu marcas valiosas.

Outras formas de obtenção de renda são endógenas à cadeia e são desenvolvidos por grupos de empresas, conforme segue.

- $\quad$ Rendas relacionais. Relacionamento superior com fornecedores e clientes.

(3) Rendas podem ser exógenas à cadeia e derivadas da natureza.

- $\quad$ Rendas de recursos. Acesso a recursos naturais.

(4) Empresas também podem se beneficiar de renda trazida por partes externas à cadeia.

- $\quad$ Rendas derivadas de políticas públicas. A empresa opera em um ambiente de governo eficiente e constrói barreiras à entrada de competidores.

- $\quad$ Rendas relacionadas à infra-estrutura. Acesso a insumos estruturais de alta qualidade, como por exemplo, telecomunicações.

- $\quad$ Rendas relacionadas ao financiamento. Acesso a capital em condições melhores que os concorrentes.

(5) Rendas são dinâmicas, isto é, novas formas são criadas ao longo do tempo e atividades que no presente possibilitam renda, são destruídas pelas forças da competição.

Kaplinsky (2005, p. 64 e 79-84) associa o êxito empresarial aos níveis de renda controlados pela organização. Quanto mais baixas forem as barreiras à entrada e quão mais fácil for replicar uma atividade, menor a renda e, portanto o sucesso empresarial. A maior parte das barreiras à entrada é construída socialmente, isto é por ações planejadas das empresas. Existem barreiras à entrada informais e as formais. Dentre aquelas classificadas como informais, que não são legalmente codificadas, estão os segredos comerciais. Isto se aplica à 
tecnologia de processo, onde o ato de registrar uma patente possibilitaria à concorrência 0 conhecimento necessário para copiar a invenção. Há outras situações, como fórmulas de produtos como bebidas e perfumes, que são de conhecimento de um número limitado de pessoas pela mesma razão. A extensão e o grau destes processos e tecnologias de produto variam em função do setor e ao longo dos tempos. Esta seria uma forma menor de barreira à entrada e da perspectiva do inovador seria sub-ótima. A outra categoria de direitos de propriedade são aqueles passíveis de registro, e que, portanto, contam com a proteção legal.

Um outro tipo de barreira à entrada é a escala. Os recursos mínimos exigidos para desenvolver uma atividade podem ser tão elevados, que, na prática, novos entrantes são excluídos. São citados os exemplos de microprocessadores e softwares aplicados de última geração. A barreira de entrada nestes casos reflete não só a escala absoluta, mas também os investimentos acumulados. As empresas estabelecidas nestes setores estão gerações à frente de um novo entrante. Não é surpreendente que a renda empresarial nestes setores seja alta e têm se sustentado desta forma por um período longo de tempo.

Não é fácil para as empresas construir estas posições nas quais as rendas são mais altas por um longo período de tempo. As empresas que chegam a esta situação, normalmente o fazem através de investimentos realizados por longos períodos de tempo. Isto significa que, além da renda possuir um caráter cumulativo, ela também tem uma trajetória. As empresas se direcionam para determinadas rotas e esta orientação acaba por constituir também um constrangimento em termos de oportunidades.

Portanto, uma primeira característica de muitas das barreiras à entrada, em especial aquelas que decorrem da inovação e da infra-estrutura ou finanças são a trajetória e a dependência do passado das empresas seja individualmente ou em grupos. '

Ao mesmo tempo, em todos os grupos de produtos a importância das atividades intangíveis e dos elementos ligados às cadeias de valor tem aumentado. Organizações que estão capacitadas, por exemplo, na otimização de estoques e logística, têm visto seu poder crescer nas cadeias de valor. 


\subsection{Estratégia empresarial}

Conolly et al (2005, p. 153-154) definem estratégia como o planejamento central utilizado por uma organização para identificar e atingir os seus objetivos e gerir os aspectos mais fundamentais de uma empresa: quem ela é e o que faz. Concorda-se com a definição de que os princípios da estratégia têm permanecido os mesmos com as mudanças tecnológicas e que os conceitos de modelagem e gestão da cadeia de valor fazem parte das competências fundamentais de uma empresa. Muitas das fontes tradicionais de vantagem competitiva nos negócios internacionais (proximidade dos mercados, design organizacional, estratégias de vendas e marketing) são de fácil replicação na atualidade. Estas estratégias estão disponíveis para a concorrência a custos equivalentes. Barney (1986, p. 798) conclui que o conceito de competição é central à noção de estratégia.

Schoemaker (1990, p. 1179-1180) observa que a premissa central da estratégia é a possibilidade de criação, de forma sistemática, de rendimentos acima da média. A questão de como estes rendimentos podem ser criados também é fundamental. Ao partir da premissa que a complexidade do ambiente é controlável, Schoemaker (1990, p. 1184) propõe que estratégia e rendimentos econômicos estão intimamente relacionados. Estratégia seria o meio através do qual se obtém maiores rendimentos econômicos. No entanto, também se alerta que a adoção deste argumento supõe que sejam aceitos argumentos como racionalidade limitada, assimetria nas competências e nos recursos, instabilidade do ambiente, a importância da história (isto é, do passado) e a existência de custos transacionais não desprezíveis.

Govindarajan e Gupta (2001, p. 16 e p. 136) afirmam que por definição, toda ação estratégica representa um diálogo entre a empresa e seu ambiente. Toda empresa deve se adaptar às mudanças no seu ambiente. Ainda assim, há escolhas. A primeira opção está relacionada a escolher se a empresa será uma das primeiras a se movimentar ou será uma retardatária quanto à antecipação destas mudanças e transformá-las em vantagens competitivas. Contudo, a escolha mais crucial está no fato que a empresa, com freqüência, tem o poder de influenciar a direção e a velocidade das mudanças no ambiente, de uma forma que o resultado favoreça a organização. Entre as mudanças fundamentais que a revolução tecnológica em andamento traz, está a transformação em rotina, da coordenação em tempo real de atividades dispersas globalmente. 
Em relação à interação da empresa com seu ambiente, o êxito em aproveitar as oportunidades que emergem e lidar com os desafios que surgem, depende de quão inteligente se é na observação e interpretação do mundo no qual opera. Um dos ingredientes centrais para construir esta inteligência é o cultivo de um conjunto de atitudes empresariais globais.

Williamson (1991A, p. 278) argumenta que um problema central da organização econômica é a adaptabilidade. Contudo, também alerta que, exceto pelas vantagens temporárias de mercado, a maior parte das empresas não possui o poder de mercado rotineiramente assumido pela literatura de estratégia empresarial. (WILLIAMSON, 1991B, p. 80).

Porter (1996, p. 65) argumenta que estratégia competitiva tem a ver com ser diferente. Ser diferente significa escolher, de forma estudada, um conjunto de atividades para entregar um composto difícil de ser igualado em termos de valor. A essência da estratégia está nas atividades: fazer de forma diferente ou fazer outras atividades (em relação à concorrência). Foss (1997, p. 1131) argumenta que a estratégia tem a ver com a descoberta das possibilidades de troca, até então desconhecidas.

Os argumentos de Williamson (1975, p. 21) podem ser interpretados como indicações que as empresas desenvolvem diferentes estratégias devido à racionalidade limitada. Esta, por sua vez envolve, além das limitações neurofisiológicas dos indivíduos, as relacionadas à linguagem.

Barney (1991, p. 116-117) afirma que os gestores possuem limitações quanto às possibilidades de manipular os atributos das empresas. Estas limitações é que trazem a imperfeição quanto à imitabilidade de recursos. No entanto, a relevância dos gestores para o desenvolvimento das vantagens competitivas sustentadas é enfatizado.

Rummelt et al (1991, p. 6) definem estratégia como o conjunto de escolhas que uma organização, frequentemente empresarial, faz com relação a: (1) Seleção de objetivos. (2) A escolha de produtos e serviços que será oferecida aos compradores. (3) O design e a configuração de políticas que definem como a empresa vai competir nos mercados. (4) Escopo competitivo. (5) Sua estrutura organizacional. Na verdade, são as forma pelas quais estas escolhas estão integradas, que faz do conjunto uma estratégia. 
Bradford Jr. (1994, p. 85-89) argumenta que as empresas devem centrar o foco em três áreas fundamentais: (1) Sua estratégia quanto à competitividade. (2) Investimento em intangíveis, como por exemplo, tecnologia, capacitação, organização e informação. (3) As ligações com outras empresas e agentes econômicos.

Kogut (1985, p. 1-4 e 27) afirma que o desenho das estratégias internacionais está baseado na interação entre as vantagens comparativas dos países e as vantagens competitivas das empresas. Estas duas vantagens determinam as respostas às questões que podem ser consideradas principais em estratégias de internacionalização: (1) Onde a cadeia de valor adicionado deve ser desmembrada em termos internacionais? (2) Em que atividades funcionais uma empresa deve concentrar suas forças? Vantagens competitivas e vantagens comparativas não são totalmente independentes entre si, no entanto é importante distinguir entre estratégias baseadas em uma, daquelas baseadas na outra.

A formulação da estratégia pode ser vista como a seleção de decisões alocativas produtomercado, que sinalizam a geração do chamado rendimento econômico. Para capturar este rendimento econômico, a empresa deve visualizar uma estratégia que é superior a da concorrência.

Os conceitos do baixo custo e da diferenciação são úteis para a classificação de estratégias competitivas, contudo falham ao não sugerir onde os custos devem ser cortados ou como os produtos devem ser diferenciados. Para estes propósitos, a cadeia de valor agregado é um conceito de fácil assimilação e ao mesmo tempo poderoso. Dependendo da estratégia que a empresa persegue, a métrica dos elos de valor agregado deve ser definida de forma diferente.

A conclusão é que um elemento crítico na formulação da estratégia internacional é a criação da flexibilidade organizacional e de incentivos que respondam às mudanças nos parâmetros econômicos entre os países. Neste aspecto, a empresa internacional pode ser entendida como a que realiza investimentos em flexibilidade que permitam que as oportunidades geradas pela turbulência ambiental sejam aproveitadas.

Kaplinsky (2005, p. 92), ao explicar seu modelo de obtenção da vantagem competitiva no nível empresarial, afirma que, de nada adianta identificar oportunidades de mercado rentáveis se a organização não pode aproveitá-las devido à falta de competências necessárias para atuar 
nos segmentos-alvo. Da mesma forma, o desenvolvimento de competências de nada adianta, se não para abordar uma necessidade de mercado, que pode ser rentável para a empresa. Então, uma tarefa básica para qualquer empresa é sistematizar sua capacidade de absorver os determinantes da mudança, necessidades de mercado e competências empresariais. É a estratégia que resulta dessa interação que permite à empresa decidir o que vai ser produzido, como vai fazê-lo e com quais recursos humanos.

Barney (1991, p. 99-101) sugere que as empresas obtêm vantagens competitivas que se sustentam através da implementação de estratégias que exploram suas forças internas, simultaneamente às oportunidades do ambiente, ao mesmo tempo em que neutralizam as ameaças externas e fragilidades internas. A chamada visão baseada em recursos (resourcebased view, $R B V$ ), visto que examina a ligação entre as características internas da empresa e seu desempenho, não pode se basear nestas idéias.

Foss e Knudsen (2003, p. 303-304) concluem que a $R B V$, além de útil, é influente. Contudo, também concluem que algumas adições ao modelo de vantagem competitiva sustentável da $R B V$. O argumento é que são necessárias as condições de incerteza e imobilidade para explicar a vantagem competitiva sustentável. Estas condições seriam não só necessárias, mas como também suficientes para que as empresas obtenham rendimentos superiores. O conceito pode ser mais profundamente compreendido através da visualização da ilustração 9, exibida na seqüência.

\section{Ilustração 9 - Vantagem competitiva sustentável}

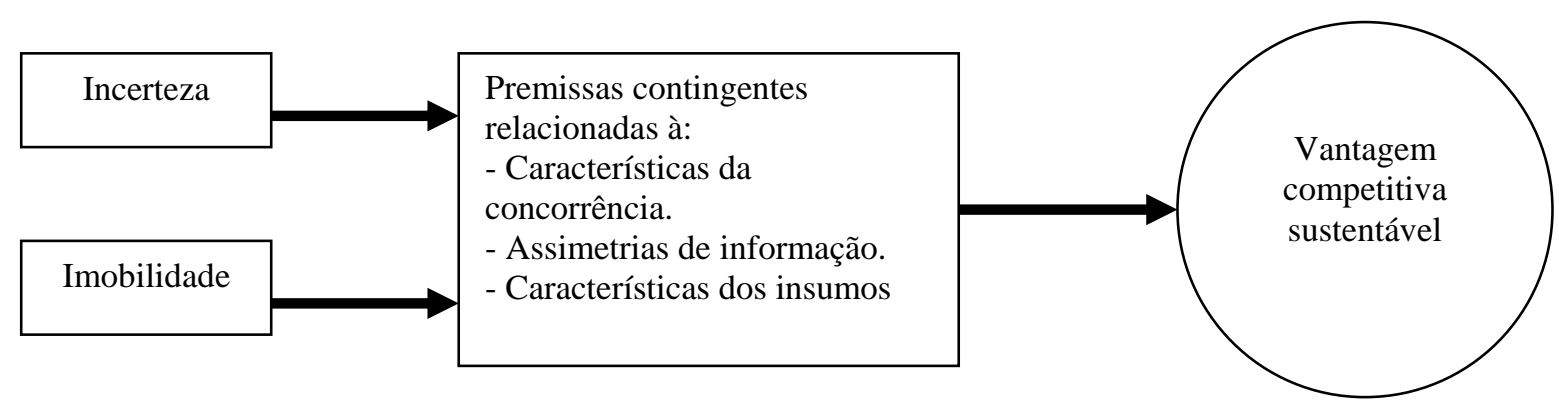

FONTE: FOSS; KNUDSEN, 2003, p. 303-304.

Dunning (2000, p. 27-29) observa que, na estratégia empresarial da atualidade, mais atenção é dada à interação entre vantagem competitiva (ou vantagens exclusivas das empresas) e vantagens comparativas (ou relacionadas à localização) dos países. A estratégia de 
localização, portanto, assume papel mais importante e deve compreender, além da localização das atividades da empresa, também a dos seus concorrentes, fornecedores e compradores. A conclusão é que uma estratégia de localização cuidadosamente planejada e executada está se tornando um fator importante a influenciar a competitividade global da empresa.

Jones (2002, p. 593) pontua que as empresas não têm respondido de forma passiva ao que chama de economias globais, mas as têm criado. Knight e Cavusgil (2004, p. 124) ao estudar casos de internacionalização precoce vão na mesma linha: a revelação de que o sucesso internacional nestas empresas inovadoras é algo engendrado a partir do que se pode chamar de intento estratégico e estratégia.

A conclusão de Knight e Cavusgil (2004, p. 130-137) é que falta de antiguidade e experiência, bem como escassez de recursos humanos, financeiros e tangíveis de modo geral, não são mais obstáculos à internacionalização em larga escala e sucesso global de uma empresa. OS gestores dos casos estudados começam com uma visão global e planejam um conjunto de capacitações no nível estratégico da empresa. Este comportamento é a origem do sucesso em um amplo escopo de mercados externos.

Palpacuer (2000, p. 353-354 e 356-357) explica que no ambiente competitivo da atualidade, a flexibilidade e a adaptabilidade se tornaram conceitos de gestão fundamentais para o desenvolvimento de uma posição competitiva sustentável. As estratégias das empresas de sucesso envolvem uma organização descentralizada e reativa, que contemple relações de cooperação não só dentro da empresa, mas também relações externas com clientes, fornecedores e concorrentes. No entanto, as empresas, nas suas estratégias, também recorrem a mecanismos tradicionais de mercado ao utilizar trabalhadores temporários e relações de subcontratação de mercado.

As estratégias organizacionais das empresas impulsionam de forma importante as mudanças nas relações de poder entre firmas. Isto ocorre através da nova dinâmica competitiva que se desenvolve na atualidade.

O argumento é que as empresas de sucesso atingem os objetivos de obter maior flexibilidade, qualidade e redução de custos de suas operações ao combinar nas suas estratégias três competências, que formam um modelo organizacional consistente. Estas estratégias incluem: 
(1) O desenvolvimento interno de competências fundamentais. (2) A terceirização (ou externalização) de competências facilmente encontráveis no mercado. (3) A quasi internalização de competências complementares. O modelo resultante destes conceitos é apresentado na seqüência (ILUSTRAÇÃO 10). Podem ser observados na ilustração 10 os novos objetivos competitivos que derivam das alterações nas condições ambientais. Também pode ser notada na ilustração 10 a estratégia organizacional baseada em competências, através da quais as empresas podem desenvolver uma vantagem competitiva durável.

\section{Ilustração 10 - Um modelo organizacional baseado em competências}

Mudanças no ambiente

- Mercados diversificados e dinâmicos

- Difusão de novas tecnologias

- Competição global mais intensa

Desenvolvimento de competências fundamentais

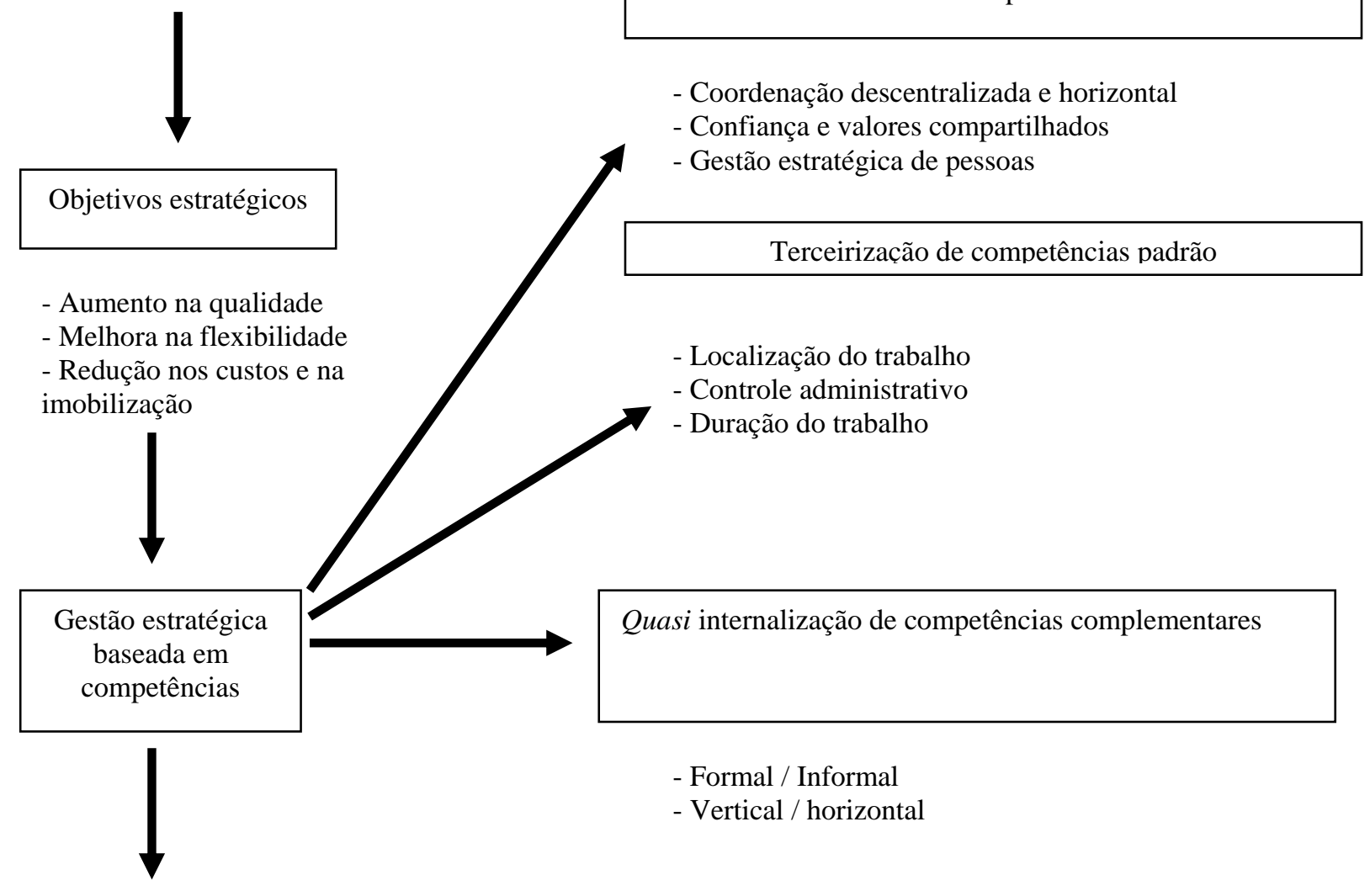

Vantagem competitiva sustentável

FONTE: Adaptado de PALPACUER, 2000, p. 357.

Palpacuer (2000, p. 371) também explica que a perspectiva estratégica na rede empresarial está preocupada principalmente com a competitividade das firmas. Esta perspectiva traz 
conceitos de gestão ao enfatizar a necessidade de comando e coordenação dentro das redes de empresas para que estas sejam fontes de vantagens competitivas superiores (para as empresas). A perspectiva estratégica permite que se faça a ligação das estratégias organizacionais à dinâmica das relações entre empresas.

De acordo com Kogut (1985, p. 27 e p. 36), uma estratégia global estaria relacionada à construção da flexibilidade, que permitiria à empresa explorar a incerteza com relação às mudanças nas taxas de câmbio, movimentos competitivos e políticas governamentais. Em resumo, uma empresa ganha flexibilidade quando diminui sua dependência de ativos já constituídos.

A conclusão é que as estratégias globais dependem da relação entre a vantagem competitiva das empresas e a vantagem comparativa dos países. A decisão de onde investir na cadeia de valor agregado de uma empresa é uma questão de vantagem competitiva. A decisão relacionada ao local onde serão desenvolvidas estas atividades constitui uma questão de vantagem comparativa.

Porter e Wayland (1995, p. 90-91) ao discorrerem sobre estratégias globais, afirmam que os objetivos empresariais devem se deslocar de medidas estáticas como retorno sobre o capital e participação de mercado, para outras classificadas como dinâmicas, por exemplo, a capacidade de evoluir. O desempenho deve ser medido em termos de sua evolução e não em termos de sua participação corrente. Os objetivos da empresa devem ser expressos em termos de sua posição competitiva no longo prazo. Algumas das vantagens competitivas que mais se sustentam ao longo do tempo são aquelas criadas por investimentos em ativos intangíveis. Podem ser mencionados como exemplos desses ativos: tecnologia, relações com fornecedores, treinamento de funcionários e acesso ao mercado. Os benefícios desses investimentos são difíceis de quantificar e reduzem a competitividade no curto prazo.

A base da vantagem competitiva é a capacidade de inovar e de se aperfeiçoar. Contudo, alertam que nenhum dos dois acontece naturalmente. Há uma tendência em todas as organizações, de manter as formas de agir do passado, melhorar a capacidade de executar abordagens ultrapassadas ou somente ajustá-las. Inovação e mudança são perturbadoras, difíceis e confusas. Poucas vezes se obtêm estímulo interno e externo, pois a reação é quase sempre negativa. O principal papel que deve ser desempenhado pela alta administração é 
superar estas tendências e motivar a organização, de forma antecipada a estes eventos. As empresas que são líderes mundiais de seus setores, além do senso de urgência, têm um foco permanente nas ameaças e desafios. Parte do ambiente para a inovação vem das práticas internas de gestão. A alocação de capital deve compreender não só ativos físicos, mas também os intangíveis como P\&D, treinamento e relacionamento com fornecedores e sistemas de informação.

Dedrick e Kraemer (1998, p. 254-260 e p. 279) notam que é tentador imitar a estratégia de outras empresas, sem se dar conta que, uma estratégia que teve resultado em um conjunto especifico de circunstâncias, poderá não funcionar em outro contexto. Ainda assim é possível aprender algo com o passado. Embora indicadores como, por exemplo, lucro, crescimento e participação de mercado tragam revelações sobre a competitividade de uma organização, eles são somente subprodutos da competitividade subjacente, que é baseada em ativos e capacitações. Também no setor de informática, é possível caracterizar os segmentos que possibilitam rendas crescentes às empresas que deles participam e aqueles de rendas decrescentes. Para competir nos segmentos que possibilitam rendas crescentes, não é suficiente uma execução melhor do que a concorrência. As empresas devem vencer nas decisões estratégicas, baseadas em fatores menos tangíveis, como por exemplo, intuição, visão e esperteza. Competir envolve a escolha dos mercados em que se vai entrar, bem como a implementação da entrada com habilidade. A gestão nesse ambiente não é orientada à produção, mas orientada à missão. A estrutura organizacional não pode ser hierárquica, pois aqueles que vão entregar o próximo produto da empresa precisam se organizar em times menores, que se reportam diretamente à alta administração, de forma a contar com um senso de direção e ao mesmo tempo ter liberdade para progredir. Sempre que a missão muda, o que ocorre com freqüência, a empresa precisa também mudar e se adaptar. Liderança significa observar a próxima geração de tecnologia, avaliar qual será seu formato e posicionar a empresa para aproveitá-la.

Com relação às abordagens estratégicas que têm funcionado em TI, em relação ao design de produto e ao marketing estratégico, o essencial, mais do que velocidade, é o chamado timing, ou seja, o momento certo. Outro aspecto importante é o desenvolvimento de ativos complementares e externalidades derivadas da rede. As empresas concorrem não só com um bom produto, mas também pela formação de alianças formais e informais de empresas que se organizam ao redor de uma tecnologia. O sucesso de uma atividade cujo design é baseado no 
conhecimento é a gestão do feedback mútuo. Isto pode ser feito através do estabelecimento de ligações mutuamente benéficas com outras empresas. Estas ligações podem ser implementadas, por sua vez, através do compartilhamento voluntário dos lucros com outras empresas, que trabalham como sub-contratadas nas redes, varejistas e desenvolvedores independentes em uma rede de software.

Finalmente, é observado que, em software, em termos de sua estratégia, as empresas locais podem se direcionar para segmentos de mercado específicos (nichos), de forma a evitar a competição direta com as grandes empresas globais. 


\section{Capítulo 3 - METODOLOGIA}

\section{1 - Definições de trabalho}

- Cadeia global de valor: Termo usado para definir um relacionamento vertical entre compradores e vendedores, normalmente empresas e que tem como objetivo a movimentação de bens ou serviços de um produtor para um comprador. O termo traz, inevitavelmente, uma análise focada em fluxos de recursos materiais, finanças, conhecimento e informações entre compradores e vendedores. (GIBBON; PONTE, 2005, p. 77).

- Capacitações: Trata-se da capacidade de uma empresa de utilizar recursos, em geral de forma combinada, através da aplicação de processos organizacionais para um fim desejado. As capacitações podem ser baseadas na informação, processos tangíveis ou intangíveis e que, além de específicos da empresa, são desenvolvidos ao longo do tempo, através de complexas interações de seus recursos. (AMIT; SCHOEMAKER, 1993, p. 35).

- Capital organizacional: Inclui a estrutura de subordinação da empresa, bem como seu planejamento formal e informal, sistemas de coordenação e controle, bem como as relações informais entre grupos internos e da empresa com aqueles no seu ambiente. (BARNEY, 1991, p. 101).

- Contrato: Trata-se de uma transação ocorrida no contexto de um arranjo legal ou não, onde os direitos, recompensas e responsabilidades das partes estão claramente definidos. (TEECE ET AL, 1997, p. 517).

- Empresa líder é a firma, muito freqüentemente, multinacional cuja perspectiva e capacidade de competição, no(s) setor(es) em que atua, são globais. Também é global a capacitação destas organizações para modelar e executar estratégias de negócios. Estas empresas determinam as referências em termos internacionais para toda a rede empresarial (RUGMAN; D’CRUZ, 2000, p. 62-63).

Investimento direto é a transferência de princípios organizacionais, ou conhecimento, de uma empresa de um país para outro. (KOGUT; ZANDER, 2003, p. 517). 
- $\quad$ Recursos: são definidos como estoques de fatores disponíveis, de propriedade ou controlados pela empresa. Recursos são convertidos em produtos finais pela utilização de outros ativos e mecanismos de ligação da empresa, como por exemplo, tecnologia, sistemas de informação gerencial e outros. (AMIT; SCHOEMAKER, 1993, p. 35)

- $\quad$ Setor: Räsänen e Whipp (1992, p. 47-49) propõem a redefinição de conceito de setor. O termo deve ser referir a uma formação histórica de atividades empresariais complementares, interligadas e que evoluem conjuntamente. Pode-se afirmar com convicção que um setor existe quando: (1) Há uma rede social que conecta as diversas partes do setor. (2) Existe uma unidade cultural entre as partes, o que torna possível a cooperação. (3) O todo tem representação política.

- A nova abordagem da tecnologia em países em desenvolvimento prefere uma definição mais ampla do termo: trata-se de um método, o qual a informação, os meios e alguma compreensão do método. A tecnologia não envolve somente o equipamento físico e processos correspondentes, mas também arranjos organizacionais e de procedimentos. A parte chamada de soft (o software) ganha relevância em relação à parte chamada de hard (o hardware). Além disto, a tecnologia inclui a organização social da produção e os processos de trabalho (PIETROBELLI, 1998, p. 7).

\section{2 - O método utilizado}

De acordo com Castro (1977, p. 33), o objetivo da metodologia é o de ajudar a compreender, nos mais amplos termos, não só o produto da pesquisa, mas o próprio processo.

O método de estudo de múltiplos casos será empregado. As variáveis utilizadas são qualitativas. Esta última escolha está ancorada na afirmação que as variáveis estratégicas são menos mensuráveis do que as demais variáveis. A maior parte das variáveis estratégicas só pode ser medida por seus efeitos. (DUNNING, 1995, p. 96).

Yin (1994, p. xiii) considera um erro a avaliação de que o estudo de caso é uma escolha pobre entre os métodos disponíveis para as investigações nas ciências sociais. O estudo de caso, além de ser uma ferramenta para investigação, nem sempre é qualitativo e pode ser 
considerado mais do que uma descrição científica de hábitos e costumes individuais. (YIN, 1994, p. xiv). Stake (1995, p. 97) nota que o pesquisador que lança mão do método do estudo de caso o faz para reconhecer e estabelecer, de forma genuína, novos significados, de forma a estabelecer conexões ainda não estabelecidas entre fenômenos conhecidos. Patton (1990, p. 99) indica outras razões para estudos de caso: há situações em que o pesquisador se confronta com situações específicas - sucessos ou fracassos incomuns - e esta técnica pode gerar informações úteis.

Na verdade, continua Yin (1994, p. xiv), as características que diferenciam o método do estudo de caso são: definição do problema, modelo de investigação, coleta de dados e reportagem elaborada. A pesquisa empírica, para desenvolver conhecimento, deve estar acompanhada de raciocínio lógico. (YIN, 1994, p. xv).

O problema estudado, com respectiva proposição teórica, se encontra no capítulo 1 deste trabalho, em especial nas ilustrações 1, 2 e 3.

Em convergência com o que indica Patton (1990, p. 160-161), há a expectativa de que este trabalho, quanto aos resultados esperados, possa contribuir para a teoria.

Yin (1994, p. xv) ainda nota que o estudo de caso pode ser o método mais apropriado para apreciar complexos fenômenos organizacionais. Acredita-se que seja esta a principal justificativa para a escolha deste método no presente estudo.

Yin (1994, p. 1) ao introduzir os conceitos do método do estudo de caso, observa que este é uma das formas de se conduzir pesquisa no campo das ciências sociais. O estudo de caso é preferível nas situações em que se deseja investigar como e porque certos eventos ocorrem. Também é adequado à análise de fenômenos contemporâneos, em um contexto de vida real.

O método do estudo de caso não permite a generalização dos resultados aqui obtidos para o universo das empresas estudadas, aliás, como Yin (1994, p. 10) também destaca.

Stake (1995, p. 7-8) também aborda o tema da generalização dos casos estudados. No seu entender, o estudo de caso parece ser uma base pobre para generalizações. O estudo de um ou poucos casos permite seu estudo de forma mais extensa. No entanto, determinadas 
generalizações são admitidas. Fala-se em generalização refinada ou modificada. Também se rotula este procedimento de pequenas generalizações que ocorrem com regularidade em estudos de caso. Grandes generalizações também podem ser modificadas por estudos de caso. O estudo de um ou algum casos pode detectar exceções a generalizações realizadas. As grandes generalizações que se deseja examinar neste trabalho são: (1) Papel da estratégia empresarial na inserção internacional através de cadeias de valor. (2) A dinâmica do aperfeiçoamento funcional, no que se refere a sua automaticidade.

Schofield (2000, p. 92-93) conclui que parece emergente o consenso entre os pesquisadores para definir que a generalização é possível nas situações em que há convergência entre a situação estudada e outras as quais se deseja aplicar os conceitos e conclusões de uma determinada investigação.

Ainda com a utilização dos argumentos de Yin (1994, p. 13) pela opção do estudo de caso, e, dado que se deseja cobrir condições contextuais - como globalização, condições competitivas, internacionalização de empresas - e verificada a dificuldade de separar estes fenômenos da atuação das empresas estudadas, a opção pelo método do estudo de caso pareceu apropriada.

Stake (1995, p. 8) nota que a característica mais saliente da pesquisa qualitativa é sua ênfase na interpretação. O processo de interpretação não se limita à modelagem do estudo, mas ocorre também na fase de coleta de dados, quando simultaneamente são examinados os seus significados e refinados os seus entendimentos. Neste estudo, a transcrição das entrevistas foi acompanhada da interpretação das informações coletadas à luz da teoria estudada. Deve ser observado que as transcrições das entrevistas e a sua interpretação não foram diretamente incluídas no relatório final. As informações relativas às entrevistas e sua interpretação foram utilizadas para a elaboração do texto do capítulo 4, análise dos resultados.

Devido ao objetivo da pesquisa ser o entendimento de complexas interações, foi escolhida a investigação qualitativa. (STAKE, 1995, p. 37). O paradigma utilizado é o da pesquisa fenomenológica, que utiliza abordagens qualitativas e naturalísticas para entender a experiência humana de forma indutiva e holística em contextos específicos (PATTON, 1990, p. 37-40). Ainda de acordo com Patton (1990, p. 37-40), as características da estratégia de pesquisa qualitativa que coincidem com o presente trabalho são: (1) Dados qualitativos. Conforme se observa nos capítulos 4 e, principalmente, 5, a descrição é volumosa e detalhada, 
foi realizada pesquisa em profundidade, com a captação das perspectivas e experiências pessoais. (2) Contato e percepções pessoais. O pesquisador teve contato direto com as pessoas, a situação e o fenômeno estudados. A experiência e as percepções do pesquisador são partes importantes da pesquisa e podem ser consideradas críticas para o entendimento do fenômeno. (3) Sistemas dinâmicos. Procurou-se dar atenção ao processo, pois foi assumido que a mudança é uma constante e está em andamento. (4) Orientação para casos especiais. Foi assumido que cada caso é especial. O primeiro nível de análise captou os detalhes dos casos individuais estudados. A análise cruzada seguiu e depende da análise individual dos casos estudados.

Patton (1990, p. 135-136) ainda observa que é possível a utilização de pesquisas qualitativas para investigação do futuro. Schofield (2000, p. 81) também aborda este tema ao afirmar que pode se considerar a generalização do que pode ser, em comparação a generalizar somente o que é. A proposta é que a pesquisa deve ser modelada de forma a também iluminar questões futuras, conforme refletido nos objetivos.

A tabela 1, que segue, apresenta informações sobre as entrevistas realizadas junto às empresas estudadas. 
Tabela 1 - Casos estudados - Informações sobre as entrevistas realizadas

\begin{tabular}{|c|c|c|c|c|c|c|}
\hline CASO & $\begin{array}{c}\text { POSIÇÃO DO } \\
\text { ENTREVISTADO } \\
\text { NA } \\
\text { ORGANIZAÇÃO }\end{array}$ & $\begin{array}{c}\text { No DE } \\
\text { PÁGINAS } \\
\text { ENTREVISTA } \\
\text { TRANSCRITA } \\
\text { (1) }\end{array}$ & $\begin{array}{l}\text { No DE PÁGINAS } \\
\text { DA } \\
\text { INTERPRETAÇÃO } \\
\text { DAS } \\
\text { INFORMAÇÕES } \\
(2) \\
\end{array}$ & $\begin{array}{c}\text { TOTAL } \\
\text { TRANSCRIÇÃO } \\
\text { + INTERPRET. } \\
\text { (3) }\end{array}$ & (2)/(1) & (3)/(1) \\
\hline A1 & $\begin{array}{c}\text { Diretor de } \\
\text { Operações da } \\
\text { América do Sul }\end{array}$ & 10 & 26 & 36 & 2,6 & 3,6 \\
\hline A2 & $\begin{array}{l}\text { Diretor Financeiro } \\
\text { e de Relações com } \\
\text { o Mercado }\end{array}$ & 6 & 25 & 31 & 4,2 & 5,2 \\
\hline A3 & CEO & 10 & 26 & 36 & 2,6 & 3,6 \\
\hline B1 & Diretor Executivo & 6 & 18 & 24 & 3 & 4 \\
\hline B2 & $\begin{array}{c}\text { Vice-Presidente } \\
\text { (antes responsável } \\
\text { pelas implantações } \\
\text { no exterior) }\end{array}$ & 7 & 17 & 24 & 2,4 & 3,4 \\
\hline B3 & $\begin{array}{l}\text { Diretor Comercial } \\
\text { para o exterior } \\
\text { mais dois } \\
\text { executivos da área } \\
\text { comercial }\end{array}$ & 8 & 22 & 30 & 2,8 & 3,8 \\
\hline C1 & $\begin{array}{l}\text { Diretores (2) de } \\
\text { UNs (um deles } \\
\text { responsável pela } \\
\text { atividade } \\
\text { internacional) } \\
\end{array}$ & 7 & 27 & 34 & 3,9 & 4,9 \\
\hline C2 & $\begin{array}{c}\text { Gerente de } \\
\text { Desenvolvimento } \\
\text { de Negócios } \\
\text { (responsável pela } \\
\text { área internacional) }\end{array}$ & 9 & 21 & 30 & 2,3 & 3,3 \\
\hline & TOTAIS & 63 & 182 & 245 & 2,9 & 3,9 \\
\hline
\end{tabular}

\section{3 - Modelo de investigação (tradução livre de research design)}


Yin (1994, p. 18) elabora sobre o tema modelo de pesquisa: trata-se da lógica que reúne as informações coletadas e conclusões a que se chega, às questões iniciais do estudo.

Yin (1994, p. 20) enumera os cinco componentes de um modelo de investigação que importam no método do estudo de caso:

1. As questões do estudo.

2. As proposições.

3. A unidade de análise.

4. A lógica que relaciona os dados às propostas.

5. Os critérios para a interpretação dos dados.

As questões do presente estudo estão colocadas nos objetivos. A unidade de análise são empresas. A partir dos objetivos colocados, foram definidos os temas para a revisão da literatura: cadeias globais de valor; aperfeiçoamento competitivo; competitividade e capacitação; governança nas cadeias, renda econômica e estratégia empresarial. A revisão da literatura destes temas deu origem a um roteiro de entrevista, que foi aplicado aos casos estudados. A análise dos resultados, compara as informações coletadas no trabalho de campo aos conceitos da literatura, de forma a atender aos objetivos propostos. A visualização da ilustração 11, que segue, auxilia na compreensão desta lógica, que é apresentada de maneira simplificada.

\section{Ilustração 11 - Componentes e lógica do modelo de investigação.}

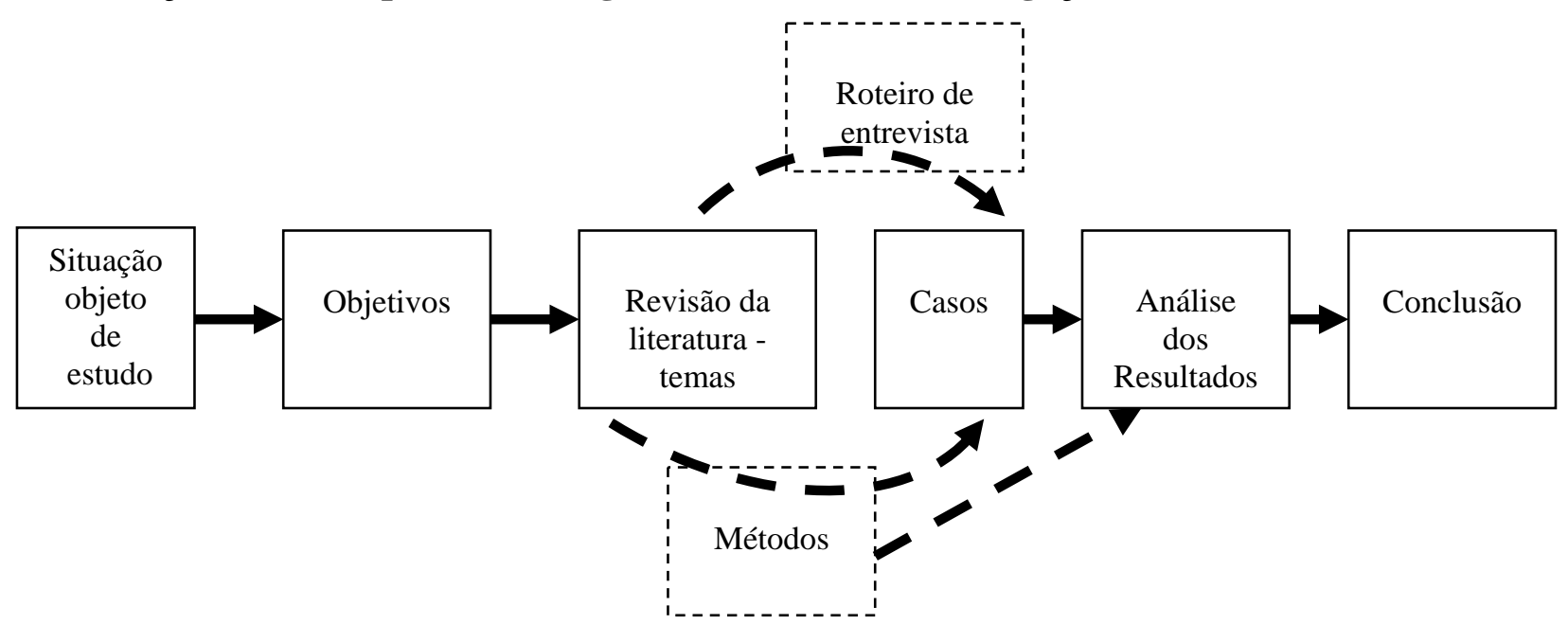

FONTE: AUTOR, 2008, com baseado nos conceitos de YIN, 1994, p. 18-20. 
As considerações elaboradas por Stake (1995, p. 15-16) sobre a modelagem da pesquisa em estudos de caso também corroboram as opções realizadas pelo autor desse estudo. Toda modelagem de pesquisa exige: organização conceitual, idéias para apresentar o entendimento do tema, pontes conceituais sobre o que já é conhecido, estruturas cognitivas para direcionar o levantamento de dados e esquemas para apresentar as interpretações para terceiros. Nas ciências sociais, a organização conceitual mais comum ocorre ao redor de hipóteses. Portanto, a seguir estão explicitadas as ações adotadas em relação a alguns destes aspectos:

- $\quad$ A organização conceitual consta nas ilustrações 1, 2 e 3.

- $\quad$ As idéias para apresentar o entendimento do tema estão colocadas no capítulo 1, no item tema e descrição do problema em estudo.

- $\quad$ As hipóteses do presente estudo também estão colocadas nas ilustrações 1, 2 e 3, bem como no quadro 1.

Patton (1990, p. 197) acrescenta que o pesquisador deve informar o propósito da pesquisa, neste caso pesquisa aplicada, e também os aspectos que seguem, com a respectiva classificação deste estudo:

- $\quad$ Foco. Amplitude versus profundidade. A opção foi pela profundidade, ainda que menor do que seria se fosse estudado um único caso.

Estratégias de amostragem. Foram escolhidas empresas de TI, fossem especializadas em software ou fossem especializadas em serviços, que têm envolvimento internacional. Morgan (2001, p. 1 e 8-9) coloca uma outra premissa para a tentativa de se compreender a internacionalização de empresas na economia global. As empresas globais são entendidas como organizações com complexos processos de contradição e conflito, que são distintos daqueles presentes nas empresas não internacionalizadas.

- $\quad$ Tipos de dados a serem coletados. Qualitativos.

- Abordagem analítica. Indutiva. Portanto, com relação às conclusões do estudo, Marconi e Lakatos (2005, p. 86) indicam que, visto o método ser indutivo, são apenas prováveis. O método indutivo infere a verdade a partir de dados particulares. As conclusões dos estudos que utilizam métodos indutivos podem trazer informações que não estavam, nem implicitamente, nas premissas.

\section{- Validação dos resultados.}

Quanto à triangulação, foram coletadas informações das empresas estudadas na imprensa, órgãos e instituições ligados ao mercado financeiro como Bolsa De Valores de São Paulo (BOVESPA) e Comissão de Valores Mobiliários (CVM), ao longo dos anos de 2005, 2006, 
2007 e primeiro quadrimestre de 2008. Estas informações foram utilizadas para a caracterização da empresa e posterior seleção. As informações coletadas nestas múltiplas fontes de dados foram comparadas e selecionadas para instruir os contatos do autor com as empresas. A única fonte de dados primária foram as empresas estudadas. Foi utilizado um único pesquisador, que é o autor do trabalho. Na análise dos resultados, estas informações coletadas em fontes de dados primários e de dados secundários foram utilizadas de maneira complementar e comparadas aos conceitos apresentados na literatura.

- $\quad$ Questões temporais. Os trabalhos de campo ocorreram no primeiro trimestre de 2008. Foi enviada correspondência às empresas no mês de dezembro de 2007. A partir da primeira semana de 2008 foram estabelecidos contatos com as empresas, por telefone e correio eletrônico, para que as datas das entrevistas fossem marcadas.

- Acesso às pessoas e registros, resistências encontradas. À medida que as entrevistas ocorriam, eram transcritas e as informações coletadas passavam por um primeiro nível de interpretação, conforme retratado na tabela 1. Neste momento da interpretação, ocorreram novos contatos com as empresas por telefone e correio eletrônico com o objetivo de esclarecer e validar as informações obtidas. Todas as transcrições das entrevistas foram validadas pelos executivos envolvidos. Foi procurado o nível administrativo mais alto das empresas estudadas, que, na maior parte das situações, indicou um membro da diretoria executiva para conversar com o autor (TABELA 1). De forma geral, aqueles que aquiesceram em colaborar com o estudo o fizeram sem resistências.

- Questões éticas e de confidencialidade. O contato com as empresas foi feito inicialmente através de carta impressa (APÊNDICE 3), enviada às sedes das empresas com postagem registrada e comprovante de recebimento. Nesta comunicação já foi indicado que as informações seriam tratadas de forma despersonalizada sem que as organizações estudadas e seus executivos fossem identificados. No decorrer dos contatos, não foi informado aos entrevistados quais eram as outras empresas que participaram do estudo. Estes compromissos assumidos impuseram que todas as referências que poderiam identificá-los, bem como suas empresas, fossem retiradas do texto, mesmo que fizessem menção a fontes de dados secundários consultadas.

As proposições colocadas no capítulo 1, em especial no item que apresenta os objetivos do trabalho vai ao encontro do que propõe Yin, (1994, p. 21) no que se refere à obrigação do pesquisador em colocar algumas proposições que auxiliam no direcionamento correto da investigação. Esta proposição deve refletir conceitos teóricos relevantes. A existência de uma 
proposição de pesquisa colabora para que o pesquisador identifique as informações relevantes sobre as organizações pesquisadas.

Foram escolhidas no total 19 empresas que atendiam ao perfil definido: empresas de TI, voltadas à prestação de serviços ou à comercialização de software, que tivessem envolvimento internacional. Foram excluídas as empresas que somente produzissem e/ou comercializassem hardware. Foi verificado ao se estudar o setor que, embora os perfis das empresas possam ser definidos, esta definição não é totalmente clara, principalmente no que se refere à atividade de software e serviços de TI. As empresas de software, em geral, prestam serviços. As empresas de serviços podem estar envolvidas no desenvolvimento de certos tipos de software. A diferença, portanto, é menos na tecnologia e mais na utilização de marcas e tipo de relacionamento com os compradores, entre outros aspectos organizacionais. Estas semelhanças e diferenças foram ratificadas pelos entrevistados. Também pesou para a escolha de empresas de serviços e empresas de software, o objetivo de investigar organizações que houvessem mudado de função na cadeia de TI (aperfeiçoamento funcional). Estes esclarecimentos convergem com o que propõe Yin (1994, p. 24), que afirma que o pesquisador deve explicitar as razões pelas quais os casos estudados foram escolhidos para responder às questões colocadas.

Das 19 empresas contatadas, 11 se dispuseram a receber o autor dentro do primeiro trimestre de 2008. Destas 11 empresas, oito estão incluídas neste trabalho. Segue a descrição do ocorrido com as três empresas que não constam no presente texto. Uma empresa que foi visitada não foi aproveitada neste estudo em virtude de não contar com envolvimento internacional, diferente do que indicam as informações que constam nos documentos divulgados pela empresa e no noticiário. Uma empresa só foi visitada quando a redação da análise dos resultados já estava a caminho da finalização e, portanto, não foi possível incluí-la no estudo. A décima - primeira empresa, embora disposta a colaborar através de seu DiretorPresidente, não foi incluída no presente texto em função das visitas não terem sido marcadas até o momento por problemas de agenda desse executivo.

Com relação ao número de casos estudados, segue a fundamentação utilizada:

- $\quad$ Yin (1994, p. 44-46) observa que, nos últimos anos, têm sido freqüente que um estudo contenha mais do que um único caso. A mesma estrutura metodológica é adotada para estudos de caso único e para estudos de múltiplos casos. Ao mesmo tempo, a justificativa para o 
estudo de um único caso não pode ser utilizada para casos múltiplos. Também se pontua que a condução de estudos de casos múltiplos pode estar além dos meios disponíveis ao pesquisador independente. Portanto, a decisão de estudar múltiplos casos deve ser tomada com ponderação. Cada caso estudado deve servir a um propósito específico no contexto da investigação.

- $\quad$ Os casos A1, A2 e A3 são empresas que comercializam softwares com suas próprias marcas.

- $\quad$ As empresas B1, B2 e B3 são empresas de serviços, que fazem implementação de softwares de terceiros. Embora a empresa B3 tenha recentemente inaugurado uma fábrica de software, estas organizações podem ser consideradas como tipicamente direcionadas à prestação de serviços.

- $\quad$ As empresas C1 e C2 são organizações de porte menor do que as demais. Estes casos foram incluídos em virtude, principalmente, de seu foco no segmento financeiro, que é um dos grandes compradores de TI, não só no Brasil, mas em todo o mundo.

Outro aspecto abordado é o da replicação. Nas situações em que são estudados múltiplos casos e se obtém resultados similares para todos, pode-se afirmar que ocorreu a replicação. (YIN, 1994, p. 45). A lógica que fundamenta a utilização múltiplos estudos de caso é a seguinte: cada caso deve ser selecionado com critério, de forma que possa se prever (nos casos estudados) resultados semelhantes. Esta situação é rotulada de replicação literal. Há outra situação em que os resultados são diferentes, mas por razões previsíveis. A esta segunda situação de replicação se dá o nome de replicação teórica.

Eisenhardt (1989, p. 536-537) também elabora sobre a seleção de casos a serem estudados. O conceito de uma população (de casos) é essencial porque define o conjunto do qual a amostra pesquisada será retirada. Também, a seleção de uma população apropriada controla variações não relevantes e auxilia na definição de limites para a generalização dos resultados, Estes procedimentos esclarecem as circunstâncias nas quais os resultados são válidos. É citado um estudo onde foram selecionados setores, o que permitiu aos pesquisadores o controle da variação relacionada ao ambiente. Neste mesmo estudo, o foco em grandes empresas constrangeu a variação devido às diferenças de porte entre as empresas.

No tocante ao número de casos necessário e suficiente para a condução do estudo, Yin (1994, p. 50) afirma que o pesquisador deve pensar no número de replicações teóricas e literais que 
deseja obter. A replicação literal é uma questão de julgamento do pesquisador, ou seja, não há uma fórmula que se possa usar para determinar os estudos que podem ser incluídos nesta classificação. Quanto à replicação teórica, uma consideração importante está relacionada ao senso de realidade da validação externa. Quando o pesquisador está em dúvida se as condições externas produzirão resultados diferentes nos casos estudados, poderá estruturar estas condições relevantes no início do estudo e identificar um número maior de casos a ser incluído. Foi o caso deste trabalho.

Hammersley e Gomm (2000, p. 2 e 14) anotam que, dentre as diversas dimensões da pesquisa através do estudo de caso, a mais importante está relacionada ao número de casos investigados. A outra dimensão, intimamente relacionada, diz respeito ao volume de informação detalhada para cada estudo. Caeteris paribus, menor o número de casos, maior pode ser o volume de informações sobre cada caso, embora esta relação seja complicada por outros fatores.

No que se refere à verificação da qualidade da pesquisa, Yin (1994, p. 32-33) propõe testes para a aferição da qualidade da investigação empírica nas ciências sociais. Segue o que foi utilizado neste estudo.

- $\quad$ Para testar a validade do construto, as fontes de evidência utilizadas são propostas no capítulo 4 (ITEM 4.3, QUADROS 14, 15 E 16) e utilizadas no capítulo 5 (item 5.2, quadros 54, 55 e 56). Estas fontes de evidências foram utilizadas na estrutura conceitual das ilustrações 1 , 2 e 3, de forma a tentar estabelecer uma cadeia. O texto relativo às informações obtidas nas empresas foi submetido aos entrevistados para verificação. Nos casos em que houve comentários dos entrevistados, o texto foi revisto. Com relação às medidas operacionais, foram utilizadas, principalmente, informações referentes à receita bruta das organizações estudadas, em um nível absoluto e em um nível que avaliasse seu crescimento recente (ano 2007 em comparação com ano 2006). No caso C1 não foi possível obter esta informação de maneira precisa, devido às fusões e aquisições que tem ocorrido no setor de TI, em especial no caso dessa organização. A coleta de dados foi direcionada de maneira firme à obtenção das informações que constavam no roteiro de entrevista. Este último, por sua vez, foi desenvolvido com base nos conceitos apresentados na revisão teórica. As mudanças específicas que são estudadas também têm origem na revisão teórica. A classificação dos casos estudados foi feita pelo autor. Para esta classificação, foi utilizada uma escala Liekert de seis posições (muito baixo, baixo, discretamente baixo, discretamente alto, alto e muito alto). 
Esta mesma escala foi utilizada na análise dos resultados no item discussão (5.1). Nas aplicações mais relevantes dos conceitos apresentados na revisão da literatura, os casos estudados foram analisados e classificados de acordo com esta escala. Esta classificação, que consta no texto do item 5.1 da análise dos resultados, bem como nos seus quadros, tabelas e ilustrações, foi utilizada para formar o julgamento do autor para a classificação final que consta no item 5.2 do capítulo 5, proposta no capítulo 4 (ITEM 4.3).

- $\quad$ A validade interna do modelo pode ser observada nas ilustrações 1, 2 e 3. Visto que a classificação dos casos foi realizada a partir de inferências do autor (pela impossibilidade de observação direta dos fenômenos), procurou-se tomar alguns cuidados como buscar suas convergências e pontos fracos.

- $\quad$ Com referência ao teste de confiabilidade, além de lançar mão do protocolo do estudo de caso, foi elaborado um banco de dados com informações de cada caso estudado, utilizado para sua descrição. Um resumo destas informações foi utilizado no capítulo 4 (ITEM 4.2), para a caracterização dos casos estudados. Os detalhes dos passos da coleta de dados podem ser encontrados no item específico.

(1) A validade do construto está relacionada ao estabelecimento de medidas operacionais corretas para os conceitos estudados. Este teste também responde às seguintes críticas: (a) Falta de medidas operacionais dos estudos de caso. (b) Julgamento subjetivo utilizado para a coleta de dados. De forma a que o pesquisador verifique a validade do construto, são recomendados dois passos: (1.1) Seleção das mudanças específicas que são estudadas (em comparação aos objetivos originais); e (1.2) Demonstração que as medidas de mudança propostas refletem as alterações selecionadas. (2) Já a validade interna, necessária para os estudos de ordem explicativa ou causal, estabelece uma relação causal, relacionada a determinadas condições que podem levar a outras; ou seja, se um evento, por exemplo, $x$, pode levar a outro evento, chamado de y. A preocupação com a questão das inferências. Um estudo de caso envolve uma inferência todas as vezes que um fenômeno não pode ser diretamente observado. As perguntas que o pesquisador deve fazer são: A inferência está correta? Todas as explicações rivais e possibilidades foram consideradas? As evidências são convergentes? As evidências parecem possuir pontos fracos? (4) Com relação à confiabilidade, esta tem a ver com a demonstração que as operações de um estudo, como, por exemplo, a coleta de dados, pode ser repetida, com os mesmos resultados. Para isto, há necessidade de documentação dos procedimentos seguidos em casos anteriores. Aqui, a 
recomendação é detalhar cada passo de forma tão operacional quanto possível. (YIN, 1994, p. 33-37).

Yin (1994, p. 27) enfatiza a essencialidade da elaboração teórica na modelagem de um estudo de caso. Este aspecto está atendido no capítulo 1 do presente trabalho. Com relação às teorias rivais, destaca-se o seguinte:

- $\quad$ A teoria de sociologia econômica sobre cadeias de valor minimiza o papel da estratégia empresarial na conexão e aperfeiçoamento das organizações que se ligam a estas cadeias. Este trabalho pretende tratar da pró atividade e sofisticação das estratégias empresariais para que a conexão seja de melhor qualidade.

- $\quad$ Gereffi (1994, 1996 e 1999), de acordo com a crítica de Humphrey, argumenta em prol da chamada evolução benigna das empresas de países em desenvolvimento nas cadeias globais de valor. Conforme as conclusões de Gereffi, o aperfeiçoamento competitivo destas empresas ocorreria automaticamente, bastando para isso a conexão às cadeias mencionadas.

Quanto ao protocolo do estudo de caso, Yin (1994, p. 63-64 e 69) nota que este além de um instrumento, contém os procedimentos e regras que deverão ser seguidos. O protocolo eleva a confiabilidade da pesquisa através do estudo de caso. Os itens do protocolo seguem:

- Visão geral do caso. Os objetivos e questões relevantes do estudo estão apresentados no capítulo 1 deste trabalho (ITEM 1.3). Os objetivos definiram os temas e limites da revisão da literatura, que teve foco nos cinco temas que seguem, com respectivos autores e obras principais, que foram utilizados.

1. Cadeias globais de valor. Albornoz e Yoguel (2004), Dedrick e Kraemer (1998), Dolan e Humphrey (2000), Gereffi (1996), Gereffi et al (1994), Gibbon e Ponte (2005), Humphrey (2003), Humphrey e Memedovic (2003), Humphrey e Schmitz (2000 e 2002), Hunter (2005), Kaplinsky (2000 e 2005), Kaplinsky e Morris (2003), Knutsen (2004), Kogut (1985), Neidik (2004), Palpacuer (2000), Regnier (2004), Rugman e D’Cruz (2000), Schmitz e Knorringa (2000), Steinfeld (2002), Sturgeon (2000 e 2003), Whitley (1996).

2. Aperfeiçoamento competitivo, competitividade e capacitação. Amastha e Momaya (2004), Barney (1991), Basile (2004), Bazan e Navas-Alemán (2001), Bradford Jr. (1994), Buckley (1988), Camuffo et al (2005), Cassiolato e Lastres (2000), Castellani (2004), Cooke e Morgan (1998), Dedrick e Kraemer (1998), Dosi (1997), Duguid (2005), Elfring e Baven (1996), Fear (1997), Gereffi (1999), Gibbon (2001 e 2003), Gibbon e Ponte (2005), Hamel e Prahalad (1989), Hamilton et al (2004), Humphrey (2003), Humphrey e 
Schmitz (2000), Humphrey et al (1998), Kaplinsky (2005), Kaplinsky e Morris (2003), Kaplinsky et al (2003), Kidluff (2005), Knight e Cavusgil (2004), Kogut (1985), Lall (2001), Maskell e Malmberg (1999), Mytelka (2000), Palpacuer (2000), Pietrobelli (1998), Ponte (2006), Porter e Wayland (1995), Roberts e Thoburn (2004), Rugman e D’Cruz (2000), Schmitz (1999 e 1999A), Schmitz e Knorringa (1999), Schmitz e Musyck (1994), Sturgeon (2002 e 2003), Teece et al (1997), Whitley (1996), Williamson (1975, 1991A, 1996 e 2002), Wortzel e Wortzel (1985).

3. Governança das cadeias. Barney (1996), Bazan e Navas-Alemán (2004), Cooke e Morgan (1998), Dedrick e Kraemer (1998), Dolan e Humphrey (2000), Gereffi (1994), Gibbon e Ponte (2005), Gwynne (2004), Humphrey e Schmitz (2000, 2002 e 2004), Kaplinsky (2005), Kaplinsky e Morris (2003), Palpacuer (2000), Palpacuer (2000), Pietrobelli (1998), Porter e Wayland (1995), Rugman e D’Cruz (2000), Sturgeon (2002), Whitley (1996) e Williamson (1975, 1985, 1991, 1996, 2002).

4. Renda econômica. Amit e Schoemaker (1993), Dedrick e Kraemer (1998), Gibbon e Ponte (2005), Kaplinsky (2005), Kaplinsky e Morris (2003), Maitland e Richard (2007), Peteraf (1993), Schoemaker (1990) e Teece et al (1997).

5. Estratégia empresarial. Barney (1986 e 1991), Conolly et al (2005), Dedrick e Kraemer (1998), Dunning (2000), Foss e Knutsen (2003), Govindarajan e Gupta (2001), Jones (2002), Kaplinsky (2005), Kogut (1985), Palpacuer (2000), Porter (1996), Porter e Wayland (1995), Rummelt (1991), Schoemaker (1990), Williamson (1975).

Para a caracterização e justificação do problema estudado, bem como para a apresentação e fundamentação dos objetivos, foram citadas nestas partes do texto obras dos autores que seguem: Amit e Schoemaker (1993), Berger et al (1999), Bernard e Jensen (1997), Conolly (1995), Henderson (1996), Dedrik e Kraemer (1998), Dicken (2001), Duguid (2005), Dunning (1993 e 2000), Easton e Araujo (1996), Foss (1993), Gereffi (2000 e 2005), Gibbon e Ponte (2005), Giuliani et al (2005), Gwynne (2004), Hauge (2006), Humphrey e Schmitz (2000), Humphrey e Schmitz (2000, 2002, 2004), Humphrey et al (1996), Hunter (2005), Jones (2002), Kaplinsky (2000), Kaplinsky e Morris (2003), Lane e Probert (2006), Lane e Probert (2006), Lester (2003), Maskell e Malmberg (1999), Mytelka (2000), Nelson (1991), Rugman e D’Cruz (2000), Schmitz (1999B), Schmitz e Knorringa (1999), Sturgeon e Florida (2000), Teece et al (1997), Vellinga (2000), Williamson (1975, 1985, 1991B e 2002). 
- Procedimentos de campo. Os sítios de pesquisa foram os escritórios das empresas estudadas, onde trabalham os executivos entrevistados. Em todos os casos, exceto no A2, são conjuntos, localizados em prédios comerciais, em alguns casos próximos das sedes dos principais compradores dos produtos. Em todos os casos estudados foi possível realizar os contatos pessoais em São Paulo, exceto em um caso que foi necessário o deslocamento até a sede da empresa na região Sul do Brasil. Não houve direcionamento para as empresas que mantém escritórios em São Paulo ou que seus executivos se dispuseram a manter reunião com o autor nessa cidade. Em um outro caso, embora a sede da empresa tenha sido visitada, neste sítio o entrevistado compareceu para a entrevista através de equipamento de vídeoconferência disponibilizado pela empresa. As conversas iniciais invariavelmente procuraram verificar se e como a empresa visitada estava envolvida internacionalmente. No caso em que este aspecto não se confirmou, o caso foi desprezado. As conversas duraram aproximadamente duas horas cada uma e seguiram o roteiro de entrevista previamente preparado (APÊNDICE 1). Previamente ao contato pessoal foi disponibilizado em todos os casos um resumo dos temas que seriam tratados (APÊNDICE 2) para que os entrevistados se preparassem e, se fosse o caso, mobilizassem outros executivos para os encontros.

- Relatório dos casos. O relatório dos casos seguiu a estrutura do roteiro de entrevista. A cada um dos itens investigados, as respostas e reações dos entrevistados eram consultadas no documento que as registrou. Foram consultados neste momento documentos obtidos nos sítios eletrônicos das empresas estudadas, bem como as matérias publicadas nos periódicos Valor, O Estado de S. Paulo, Exame, Gazeta Mercantil e também em alguns veículos especializados em notícias do setor de TI.

\section{4 - A coleta de dados}

Patton (1990, p. 169-185) nota as lógicas distintas nos métodos quantitativos e qualitativos para os procedimentos de seleção da amostra. A pesquisa qualitativa tipicamente se concentra em obter profundidade em pequenas amostras, que são selecionadas intencionalmente.

Diferente dos métodos quantitativos, que dependem de amostras maiores selecionadas aleatoriamente, visto que nestas pesquisas se pretende a generalização. A lógica e o poder da amostragem proposital ou intencional repousam na seleção de casos que possuam fartura de informações para o estudo em profundidade. Casos que contam com informação em 
abundância são definidos como aqueles em que se pode aprender muito sobre questões fundamentais da pesquisa. Há diferentes estratégias para selecionar propositadamente casos que contém informação farta. Foi utilizada uma combinação das estratégias que seguem. (1) Seleção de casos especiais. A idéia nessa estratégia é que os pesquisadores envolvidos avaliem através do estudo de que casos podem aprender mais e os selecionem. (2) Amostragem por intensidade. Envolve a mesma lógica da amostragem dos casos extremos, mas com menos ênfase nesses casos. Uma amostragem por intensidade consiste de casos ricos em informação que manifestam o fenômeno de interesse intensamente, mas não de forma extremada. Os casos extremos, como comparação, são tão incomuns que distorcem a manifestação do fenômeno de interesse. Já na lógica da amostragem por intensidade, o pesquisador procura exemplos ricos ou ótimos do fenômeno de interesse, mas que não são incomuns. Esta forma de seleção da amostra envolve informação prévia e considerável julgamento. (3) Amostras homogêneas. Em contraste direto com a amostra de variação máxima, há a estratégia de selecionar uma amostra pequena e homogênea. O propósito aqui é a descrição de um subgrupo específico em profundidade. A amostragem deste tipo tipicamente envolve entidades com históricos e experiências similares. Serve ao propósito de dar foco, reduzir a variação e simplificar a análise. A homogeneidade nos casos estudados está na atividade desenvolvida e na interação com o exterior, comum a todos. (4)

Amostragem de casos típicos. Na descrição dos participantes de um estudo, pode ser útil apresentar um perfil qualitativo de um ou mais casos típicos para àqueles que não estão familiarizados com o assunto. Estes casos são selecionados com a cooperação de informanteschaves, que podem auxiliar na identificação do que é típico. O objetivo da apresentação de um perfil qualitativo de um ou mais casos típicos é descrever e ilustrar o que é típico para aqueles que não estão familiarizados com as circunstâncias; não se trata de elaborar generalizações sobre um determinado universo. A amostra é ilustrativa e não definitiva. Com este tipo de amostragem, o que se deseja são os casos ordinários, que não se destacam. A dificuldade aqui está em caracterizar o que é típico. Utilizada em pesquisa que se deseja destacar o que é típico, normal e/ou médio. (5) Amostragem por critério. A lógica deste tipo de amostragem está na revisão e estudo de todos os casos que apresentam algum critério pré-determinado de importância. Incidentes críticos podem ser fontes para a amostragem por critério. O importante é se certificar do entendimento dos casos que provavelmente são fartos em informação. (6) Amostragem de casos importantes da perspectiva política. Uma variação das estratégias de amostragem envolve a seleção - e algumas vezes a exclusão - de casos ou sítios a serem estudados. Nesta pesquisa, esta estratégia foi implementada pela seleção de 
organizações filiadas a associações de classe, como, por exemplo, mas não limitado à Associação Brasileira de Software e Serviços para Exportação (BRASSCOM).

Patton (1990, p. 181) propõe que, ao selecionar a amostra, a combinação de estratégias também é uma abordagem a ser considerada. Ou seja, como foi feito neste estudo, as abordagens apresentadas não são mutuamente exclusivas. Também, não são as únicas formas de conduzir a amostragem em uma pesquisa qualitativa. O princípio que norteia todas estas abordagens é a seleção de casos fartos em informação.

Outra consideração é que não há regras com relação ao tamanho da amostra em pesquisa qualitativa. O tamanho da amostra necessário depende dos objetivos da pesquisa, do que trará credibilidade ao estudo e também do que pode ser feito no tempo e com os recursos existentes. Uma pesquisa com menor profundidade, com um número maior de casos (ou entrevistados), pode ser especialmente útil na exploração de um fenômeno e na tentativa de documentar diversidade e na compreensão de variações. Foi o caso deste trabalho. Ao invés de se optar por um estudo de caso único, optou-se por um número maior de casos, com menor profundidade em relação a um único caso. Em pesquisa qualitativa, uma amostra só parece pequena se comparada ao tamanho de uma amostra necessária para representatividade, da população de onde foi retirada. A lógica da técnica de amostragem intencional é bem diferente da lógica de amostra probabilística. (PATTON, 1990, p. 181).

Schofield (2000, p. 93) também relaciona os objetivos do estudo a sua modelagem. Ao se estudar o que pode ser (em comparação a se estudar o que é), as técnicas de seleção da amostra incluem a procura de casos, ou de situações, que provavelmente se tornarão mais comuns com a passagem do tempo. A idéia é que os casos com envolvimento com o exterior vão se tornar mais comuns com o passar do tempo.

O quadro 8 que segue contribui para uma visualização mais clara das fontes para a obtenção de informações e técnicas utilizadas neste estudo. 
Quadro 8 - Fontes de obtenção de informação e técnicas utilizadas

\begin{tabular}{c|c|c|c|}
\hline $\begin{array}{c}\text { TIPOS DE } \\
\text { DADOS }\end{array}$ & ETAPA & $\begin{array}{c}\text { TÉCNICAS } \\
\text { DE COLETA }\end{array}$ & FONTES DE DADOS \\
\hline Secundários & $\mathbf{1}$ & $\begin{array}{c}\text { Exame de informações } \\
\text { publicadas na imprensa, } \\
\text { consulta às associações } \\
\text { setoriais. }\end{array}$ & $\begin{array}{c}\text { O Estado de S. Paulo, Valor, e Gazeta } \\
\text { Mercantil e Exame. Empresas } \\
\text { especializadas como o IDC e } \\
\text { associações de classe (ABES e } \\
\text { BRASSCOM) }\end{array}$ \\
\hline Primários & 2 & Entrevista focada & $\begin{array}{c}\text { Empresas de TI com envolvimento } \\
\text { internacional. }\end{array}$ \\
\hline Secundários & 3 & $\begin{array}{c}\text { Levantamento de } \\
\text { documentos }\end{array}$ & $\begin{array}{l}\text { Foram utilizados documentos } \\
\text { disponibilizados pelas empresas no seu } \\
\text { sítio eletrônico, para órgãos do } \\
\text { mercado de capitais, como a Comissão } \\
\text { de Valores Mobiliários (CVM, 2007) e } \\
\text { BOVESPA (2008) e, também } \\
\text { publicadas na imprensa. }\end{array}$ \\
\hline
\end{tabular}

Há duas coletas de dados secundários: uma delas previamente à pesquisa de campo e a segunda na fase de análise dos resultados.

Yin (1994, p. 78-79) aborda as fontes de evidências para um estudo de caso: documentos, registros, entrevistas, observação direta, observação dos participantes e elementos físicos. É recomendado não deixar de lado as múltiplas fontes de evidências. É notado também que a cadeia de evidências, isto é, as ligações explícitas entre as questões, os dados coletados e as conclusões a que se chega. Yin (1994, p. 90) propõe três princípios de coleta de dados, conforme segue.

O primeiro princípio é a utilização de fontes múltiplas de evidências. Embora muitas pesquisas tenham sido desenvolvidas somente com uma fonte de evidências, é recomendado que sejam utilizadas fontes múltiplas. A razão da importância das múltiplas fontes de evidência está na possibilidade do pesquisador elaborar sobre um aspecto mais amplo de questões históricas, relacionadas à atitude e também comportamentais. No entanto, a vantagem mais destacada está no desenvolvimento de linhas convergentes de pesquisa, ou seja, de um processo de triangulação. Os resultados e conclusões de um estudo nestas circunstâncias são mais precisos e poderosos se baseados em diferentes fontes de informação. Aqui é recomendada a triangulação das fontes de informação. Além das entrevistas, foram 
utilizados documentos disponibilizados pelas empresas no seu sítio eletrônico, para órgãos do mercado de capitais, como a BOVESPA (2005, 2006, 2007 e 2008) e a CVM (2007) e publicadas na imprensa.

Stake (1995, p. 107) também aborda a questão da triangulação. Na verdade, na busca pela correta representação da verdade e pelas explicações alternativas é necessário disciplina e protocolos que não dependam somente da intuição e boas intenções de proceder corretamente. Na pesquisa qualitativa estes protocolos recebem o nome de triangulação.

Para Yin (1994, p. 90-99), o segundo princípio é a criação de um banco de dados dos casos estudados. O banco de notas dos casos estudados é a forma mais comum em estudos de caso. O banco de dados dos casos estudados, além das informações publicamente disponibilizadas, contém o conteúdo das entrevistas e sua interpretação. A redação destes dois últimos itens segue a estrutura do roteiro de entrevista.

O terceiro princípio é manter a cadeia de evidências. A obediência a este princípio aumenta a confiabilidade da informação em um estudo de caso. O princípio permite ao observador externo seguir a derivação de qualquer evidência, das questões iniciais de pesquisa às conclusões do estudo. A qualidade do estudo também pode aumentar, pois o problema metodológico de determinação da validade do construto é superado. A eventual inspeção do banco de dados deve permitir que as evidências sejam reveladas, bem como as circunstâncias em que foram colocadas. Também é notado que estas circunstâncias devem ser consistentes com os procedimentos específicos e questões do protocolo do estudo de caso. Finalmente, a leitura do protocolo deve indicar a ligação entre o conteúdo do protocolo e as questões iniciais do estudo.

Stake (1995, p. 108) também aborda este tema ao afirmar que não basta ao pesquisador a correta representação da realidade ao se efetuar medições. É necessária uma lógica na interpretação do significado destas medições.

Yin (1994, p. 80) avalia pontos fortes e as fragilidades das fontes de evidências utilizadas neste estudo, conforme pode ser observado no quadro 9 a seguir. 
Quadro 9 - Fontes de evidências utilizadas com seus respectivos pontos fortes e fracos

\begin{tabular}{|c|c|c|}
\hline $\begin{array}{c}\text { FONTES DE } \\
\text { EVIDÊNCIAS }\end{array}$ & $\begin{array}{l}\text { PONTOS } \\
\text { FORTES }\end{array}$ & FRAGILIDADES \\
\hline Documentação & $\begin{array}{l}\text { - Estabilidade. Possibilita revisão. } \\
\text { - Não invasiva. Não é criada a partir de um } \\
\text { estudo de caso. } \\
\text { - Exatidão. Contém nomes, referências e } \\
\text { detalhes de um evento. } \\
\text { - Cobertura ampla. Período amplo de tempo, } \\
\text { muitos eventos e circunstâncias. }\end{array}$ & $\begin{array}{l}\text { - Recuperabilidade. Pode ser baixa. } \\
\text { - Seletividade direcionada, se a coleta for } \\
\text { incompleta. } \\
\text { - Viés ao relatar, reflete direcionamento } \\
\text { involuntário do autor. } \\
\text { - Acesso. Pode ser propositalmente impedido. }\end{array}$ \\
\hline Registros & $\begin{array}{l}\text { - Igual à documentação. } \\
\text { - Precisos e quantitativos. }\end{array}$ & $\begin{array}{l}\text { - Igual à documentação. } \\
\text { - Acessibilidade devido a razões particulares. }\end{array}$ \\
\hline Entrevistas & $\begin{array}{l}\text { - Foco no tópico estudado. } \\
\text { - Possibilita inferências baseadas em } \\
\text { percepções. }\end{array}$ & $\begin{array}{l}\text { - Viés devido a questões mal construídas. } \\
\text { - Direcionamento dos respondentes. } \\
\text { - Imprecisões devido a problemas relacionados } \\
\text { à lembrança inadequada. } \\
\text { - Reflexividade. Entrevistados respondem o } \\
\text { que o entrevistador deseja ouvir. }\end{array}$ \\
\hline
\end{tabular}

FONTE: YIN (1994, p. 80)

Yin (1994, p. 84-85) avalia que a entrevista é uma das fontes de informação mais importantes para o pesquisador. Esta fonte é qualificada como essencial. As entrevistas podem assumir diversas formas. Neste trabalho foi utilizada a entrevista focada. Nesta o respondente é entrevistado por um curto período de tempo, por exemplo, uma hora (foram ao redor de duas horas em cada uma das entrevistas, mais os complementos por correio eletrônico). Neste caso, as entrevistas ainda são abertas em termos de escopo e assumem uma forma conversacional. Foi seguido um conjunto de tópicos derivados do protocolo do estudo de caso. Foi utilizado o que é mais comum em estudos de caso, que são as entrevistas de natureza aberta. Nestas, o pesquisador, além dos fatos, indaga a opinião dos respondentes. Em algumas situações, é possível solicitar ao respondente que compartilhe sua percepção sobre certas ocorrências e estas percepções podem ser utilizadas para aprofundar a pesquisa. A essencialidade das entrevistas como fonte de evidências nos estudos de caso está ligada ao fato de que a maioria dos estudos de caso tem a ver com assuntos humanos. No entanto, como as entrevistas são relatos verbais, é recomendado que os dados obtidos em entrevistas sejam fortalecidos com informações obtidas de outras fontes. (YIN, 1994, p. 85).

\section{5 - Procedimentos para a análise dos resultados}


Conforme Yin (1994, p. 102) a análise dos dados consiste em examinar, categorizar ou recombinar de outras formas as evidências, de forma a responder às proposições do estudo. $\mathrm{Na}$ análise, não há fórmulas ou receitas para direcionar o pesquisador. A qualidade dos resultados depende em boa parte do rigor do pesquisador, bem como da apresentação suficiente de evidências e considerações sobre consideração cuidadosa das interpretações alternativas. Eisenhardt (1989, p. 541) enfatiza que o pesquisador constantemente compara teoria e dados e o faz de forma recorrente, na direção de uma teoria que se ajuste ao que coletou.

Eisenhardt (1989, p. 539-540) registra que a análise de dados é o principal na elaboração de teorias a partir de estudos de caso, embora também reconheça sua dificuldade e anote que se trata da parte menos codificada do método. Nas circunstâncias em que o problema de pesquisa é aberto, o volume de dados pode chegar a ser assustadoramente volumoso. Foi o caso, como ilustra a tabela 1, neste capítulo. A análise dos casos tipicamente envolve a elaboração de relatórios descritivos para cada organização estudada, o que foi feito no capítulo 4, previamente à análise realizada no capítulo 5. Estes relatórios são fundamentais para o compartilhamento de percepções.

Novamente de acordo com Yin (1994, p. 102-112), a estratégia preferida é a proposição teórica que conduz ao estudo de caso. O objetivo original e modelagem do estudo de caso, presumivelmente, foram baseados na proposição teórica. A proposição teórica deve dar origem a uma série de questões de pesquisa, à revisão da literatura e a novas percepções. A proposição teórica modela o plano de plano de coleta de dados e, portanto, prioriza as estratégias analíticas relevantes.

A validade externa estabelece o domínio no qual resultados do estudo podem ser generalizados. O problema da validade externa tem sido uma barreira nos estudos de caso. Os críticos, em geral, afirmam que o método do estudo de caso configura uma base pobre para generalizações. Contudo, esta crítica está baseada na lógica das pesquisas do tipo survey, nas quais os resultados de uma amostra, desde que corretamente selecionada e coletada, podem ser prontamente generalizados para um universo mais amplo. Contudo, é notado que esta analogia a amostras e universos está incorreta quando se lida com estudos de caso. A lógica da pesquisa tipo survey se fundamenta na generalização estatística, ao passo que estudos de caso propõem a generalização analítica. Na generalização analítica, o pesquisador se 
empenha para generalizar um conjunto particular de resultados para uma teoria mais ampla. Contudo, esta generalização não é automática. A teoria deve ser testada em outros casos, onde a teoria especifica que resultados semelhantes tendem a ocorrer.

Mitchell (2000, p. 183) também liga a confiabilidade do estudo de caso e as possibilidades de extrapolação de um caso individual para o processo social em geral à sua conexão com uma estrutura teórica apropriada. O racional para a extrapolação de uma amostra probabilística para a população ocorre em conjunto com uma declaração sobre a confiança deste procedimento, chamado de inferência estatística. Já a inferência lógica ou científica, elabora sobre a confiança que se pode ter sobre a conexão teórica entre as características observadas na amostra e as da população. Nos estudos de caso, a inferência estatística não se aplica e o processo inferencial está baseado nas ligações teóricas necessárias das características do caso analisado. A validade da extrapolação não depende da tipicidade ou da representatividade do caso, mas do poder de convencimento da argumentação teórica. Portanto, a conclusão deste argumento é que o estudo de caso pode ser utilizado analiticamente se estiver conectado em uma estrutura teórica apropriada, o que pode ser verificado no presente estudo.

A análise dos resultados, que realiza a ligação entre as proposições e os casos estudados, utiliza o conceito de verificação de padrões, com o qual também concorda Yin (1994, p. 25). Yin (1994, p. 31) propõe a generalização teórica ou generalização analítica para o método do estudo de caso em comparação com a generalização estatística.

(3) A validade externa estabelece o domínio no qual resultados do estudo podem ser generalizados. O problema da validade externa tem sido uma barreira nos estudos de caso. Os críticos, em geral, afirmam que o método do estudo de caso configura uma base pobre para generalizações. Contudo, esta crítica está baseada na lógica das pesquisas do tipo survey, nas quais os resultados de uma amostra, desde que corretamente selecionada e coletada, podem ser prontamente generalizados para um universo mais amplo. Contudo, é notado que esta analogia a amostras e universos está incorreta quando se lida com estudos de caso. A lógica da pesquisa tipo survey se fundamenta na generalização estatística, ao passo que estudos de caso propõem a generalização analítica. Na generalização analítica, o pesquisador se empenha para generalizar um conjunto particular de resultados para uma teoria mais ampla. Contudo, esta generalização não é automática. A teoria deve ser testada em outros casos, onde a teoria especifica que resultados semelhantes tendem a ocorrer. 
Mitchell (2000, p. 183) também liga a confiabilidade do estudo de caso e as possibilidades de extrapolação de um caso individual para o processo social em geral à sua conexão com uma estrutura teórica apropriada. O racional para a extrapolação de uma amostra probabilística para a população ocorre em conjunto com uma declaração sobre a confiança deste procedimento, chamado de inferência estatística. Já a inferência lógica ou científica, elabora sobre a confiança que se pode ter sobre a conexão teórica entre as características observadas na amostra e as da população. Nos estudos de caso, a inferência estatística não se aplica e o processo inferencial está baseado nas ligações teóricas necessárias das características do caso analisado. A validade da extrapolação não depende da tipicidade ou da representatividade do caso, mas do poder de convencimento da argumentação teórica. Portanto, a conclusão deste argumento é que o estudo de caso pode ser utilizado analiticamente se estiver conectado em uma estrutura teórica apropriada.

A análise dos resultados, que realiza a ligação entre as proposições e os casos estudados, utiliza o conceito de verificação de padrões, com o qual também concorda Yin (1994, p. 25). Na interpretação dos dados coletados, são propostos critérios para identificar as convergências.

Yin (1994, p. 31) propõe a generalização teórica ou generalização analítica para o método do estudo de caso em comparação com a generalização estatística. Eisenhardt (1989, p. 541) enfatiza que o pesquisador constantemente compara teoria e dados e o faz de forma recorrente, na direção de uma teoria que se ajuste ao que coletou.

Quanto às formas dominantes de análise, a primeira é a verificação de padrões. Esta lógica compara um padrão empírico verificado com um padrão previsto. Se ocorrer a coincidência do padrão, os resultados do estudo de caso reforçam a validade interna do construto. Se o estudo de caso é explanatório, os padrões podem estar relacionados às variáveis dependentes ou independentes do estudo (ou a ambas).

Marconi e Lakatos (2005, p. 139) pontuam que variável pode ser uma classificação ou medida, que varia. Trata-se de um conceito operacional que contém ou apresenta valores ou aspectos, entre outras características, e que é discernível em um objeto de estudo e passível de 
mensuração. Estes valores podem ser quantidades, qualidades, características, magnitudes, frações etc., que se alteram em cada caso particular.

Marconi e Lakatos (2005, p. 139-140) situam as variáveis entre os fatos, fenômenos, comportamentos e atividades reais e as hipóteses, como pode ser visualizado na ilustração 12, que segue.

\section{Ilustração 12 - Os três níveis no universo da ciência}

Nível 3

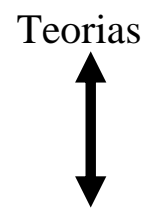

Nível 2

$$
\text { Hipóteses }
$$

Variáveis

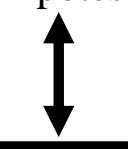

Nível 1

Observações

(fatos, fenômenos, comportamentos e atividades reais)

FONTE: MARCONI; LAKATOS (2005, p. 140)

Marconi e Lakatos (2005, p. 140) conceituam as variáveis em independentes e dependentes. A variável independente é aquela que influencia, determina ou afeta outra variável; é fator determinante ou causa para determinado resultado, efeito ou conseqüência; é (geralmente) o fator manipulado pelo pesquisador, na sua tentativa de assegurar a relação com um fenômeno observado ou a ser descoberto, a fim de verificar que influência exerce sobre um possível resultado.

Já a variável dependente é conceituada como aqueles valores (podem ser fenômenos ou fatores, por exemplo) a serem explicados ou descobertos, em virtude de serem influenciados ou afetados pela variável independente; é o fator que aparece, desaparece ou varia na medida em que o pesquisador introduz, tira ou modifica a variável independente; trata-se da propriedade ou fator que é efeito, resultado, conseqüência ou resposta a algo que foi manipulado (variável independente). 
Em uma pesquisa, a variável independente é o antecedente e a variável dependente é o conseqüente. Os cientistas fazem predições a partir de variáveis independentes para variáveis dependentes. Ao contrário, quando se deseja explicar um fato ou fenômeno encontrado variável dependente - procuram a causa (variável independente).

No quadro 1, no capítulo 1, estão dispostas as variáveis dependente e independente.

Com relação à precisão na convergência de padrões, o procedimento não se fundamenta em comparações precisas. As comparações entre o padrão previsto e o padrão de fato não envolvem critérios quantitativos ou estatísticos. A pequena precisão que estes procedimentos têm, permite liberdade de julgamento ao pesquisador, que pode ser excessivamente restritivo para determinar que um padrão fosse violado ou exageradamente leniente na decisão de identificar a convergência a certo padrão. Um cuidado que o pesquisador deve tomar ao utilizar o estudo de caso, dada sua pequena precisão, é evitar a postulação de padrões muito sutis. Os resultados de estudo de caso, provavelmente, levam a que sejam encontradas convergências ou divergências mais superficiais.

Para que um fenômeno seja explicado, deve ser estipulado um conjunto de ligações causais sobre o mesmo. No presente trabalho, isto foi feito nas ilustrações 1,2 e 3 no capítulo 1. Estas ligações causais são equivalentes às variáveis independentes descritas quando são utilizadas as explicações concorrentes. Na maior parte dos estudos, as ligações podem ser complexas e difíceis de serem medidas de maneira precisa. Na maior parte dos estudos de caso, a elaboração de explicações ocorre na forma narrativa. Devido a baixa precisão destas narrativas, os melhores estudos de caso são aqueles em que as explicações refletem alguma proposição teórica significante. Como exemplo, as ligações causais podem refletir percepções críticas sobre um processo ou sobre a teoria das ciências sociais. As propostas relativas a um processo, se corretas, podem levar a recomendações para ações futuras. Já as propostas relacionadas às ciências sociais, se corretas, podem levar a contribuições na elaboração de teorias.

No processo de construção de explicações, sua natureza recorrente é objeto de considerações. O processo de construção de explicações, para os estudos de caso explanatórios, não tem sido bem documentado em termos operacionais. No entanto, uma característica importante é que a explicação final seja resultado de uma série de recorrências: 
- Elaboração de uma proposição teórica inicial. Ou uma proposta inicial sobre comportamento social.

- Comparação dos achados de um caso inicial em comparação à proposta teórica inicial.

- Revisão da proposta inicial.

- Comparação de outros detalhes do caso com a revisão.

- Nova revisão da proposição teórica inicial.

- Comparação da revisão aos fatos de um segundo, terceiro ou mais casos.

- Repetição deste processo quantas vezes for necessário.

Neste sentido, a explicação final pode não ser completamente estipulada no início do estudo e, portanto, difere neste respeito da s abordagens de verificação de padrões previamente descritas. Aqui, as evidências do estudo de caso são examinadas, as propostas teóricas são revisadas e levam um novo escrutínio das evidências, de modo repetitivo.

A construção gradual de uma explanação é similar ao processo de refinamento de um conjunto de idéias, no qual um aspecto importante é considerar outras explicações plausíveis, até concorrentes. O objetivo é apresentar como estas explicações não se sustentam, em face das evidências encontradas nos casos estudados. Se esta abordagem é aplicada a estudos de múltiplos casos, o resultado do processo de elaboração de explicações é também a criação da análise cruzada dos casos, ao invés de sua análise individual.

Para Eisenhardt (1989, p. 540), a análise individual dos casos, em estudo de múltiplos casos, deve ser combinada com a análise cruzada dos casos, a fim de buscar padrões. O risco é que o pesquisador chegue a conclusões prematuras, ou até mesmo falsas, como resultado de vieses no processamento de informações. Portanto, uma forma de comparar os casos com qualidade é contrabalançar estas tendências negativas com a avaliação dos dados de muitas maneiras divergentes.

Potenciais problemas na elaboração de explicações. Novamente para Yin (1994, p. 102-112), um problema potencial que o pesquisador enfrenta está relacionado, à medida que utiliza a recorrência, ao afastamento do escopo original do estudo. Portanto, constante referência ao propósito original da investigação e possíveis explicações alternativas podem ajudar a minorar este problema potencial. 
Com relação à análise dos dados, Yin (1994, p. 123-124) sugere que os seguintes princípios sejam seguidos: (1) A análise deve enfatizar que se fundamenta em todas as evidências relevantes e disponíveis. A análise deve mostrar que a interpretação considerou todas as evidências, sem deixar aspectos descobertos. (2) A análise deve incluir todas as explicações alternativas. Se há possibilidade de haver uma explicação alternativa para algum ou alguns dos resultados, esta deve ser valorizada. Deve-se explicitar se há evidências para suportar esta explicação rival. Se houver, deve-se elaborar sobre os resultados. Se não houver, como a explicação rival pode ter sua elaboração revista para pesquisa em estudos futuros. (3) A análise deve atender ao aspecto mais significante do caso estudado. (4) O pesquisador deve trazer seu conhecimento anterior para o estudo em questão.

Stake (1995, p. 40-42) também aborda a interpretação como um método. Toda pesquisa depende de interpretação, contudo, nas pesquisas de cunho qualitativo, as responsabilidades interpretativas do pesquisador se estendem à atividade de campo.

Eisenhardt (1989, p. 533) apresenta as idéias que podem ser visualizadas no quadro 10 que segue para o processo de elaboração teórica a partir de pesquisas baseadas em estudos de caso. 
Quadro 10 - O processo de elaboração teórica a partir de estudos de caso

\begin{tabular}{|c|c|c|}
\hline PASSO & ATIVIDADE & RAZÃO \\
\hline Início & $\begin{array}{l}\text { - Definição do problema de } \\
\text { pesquisa } \\
\text { - Elaboração de um construto } a \\
\text { priori }\end{array}$ & $\begin{array}{l}\text { - Foca o esforço } \\
\text { - Possibilita melhor fundamentação das medidas } \\
\text { do construto. }\end{array}$ \\
\hline Seleção de casos & $\begin{array}{l}\text { - Nem teoria, nem hipóteses. } \\
\text { - População especificada }\end{array}$ & $\begin{array}{l}\text { - Mantém a flexibilidade teórica } \\
\text { - Constrange desvios e modela a validade } \\
\text { externa }\end{array}$ \\
\hline $\begin{array}{l}\text { Modelagem de } \\
\text { instrumentos e } \\
\text { protocolos }\end{array}$ & $\begin{array}{l}\text { - Múltiplos métodos de coleta de } \\
\text { dados. }\end{array}$ & $\begin{array}{l}\text { - Fortalece a fundamentação teórica pela } \\
\text { triangulação das evidências. }\end{array}$ \\
\hline Pesquisa de campo & $\begin{array}{l}\text { - Superposição de coleta e análise } \\
\text { de dados. } \\
\text { - Métodos flexíveis e } \\
\text { oportunísticos de coleta de dados. }\end{array}$ & $\begin{array}{l}\text { - Agiliza a análise e revela ajustes úteis à coleta } \\
\text { de dados. } \\
\text { - Permite ao pesquisador aproveitar temas } \\
\text { emergentes e características particulares do caso } \\
\text { estudado. }\end{array}$ \\
\hline Análise de dados & $\begin{array}{l}\text { - Análise interna do caso. } \\
\text { - Busca de padrão nos casos } \\
\text { através da utilização de técnicas } \\
\text { divergentes. }\end{array}$ & $\begin{array}{l}\text { - Ganho de familiaridade com os dados e } \\
\text { geração preliminar de teorias. } \\
\text { - Força os pesquisadores a avaliar além das } \\
\text { impressões iniciais e ver as evidências através } \\
\text { de lentes múltiplas. }\end{array}$ \\
\hline $\begin{array}{l}\text { Modelagem de } \\
\text { hipóteses }\end{array}$ & $\begin{array}{l}\text { - Tabulação recorrente das } \\
\text { evidências para cada construto. } \\
\text { - Replicação, não amostragem, } \\
\text { lógica nos casos. } \\
\text { - Procura de evidências } \\
\text { explicativas atrás das relações. }\end{array}$ & $\begin{array}{l}\text { - Aperfeiçoa a definição de construtos, validade } \\
\text { e mensurabilidade. } \\
\text { - Confirma, amplia e aperfeiçoa a teoria. } \\
\text { - Constrói a validade interna. }\end{array}$ \\
\hline $\begin{array}{l}\text { Cotejamento com a } \\
\text { literatura }\end{array}$ & $\begin{array}{l}\text { - Comparação com a literatura } \\
\text { conflitante. } \\
\text { - Comparação com a literatura } \\
\text { similar. }\end{array}$ & $\begin{array}{l}\text { - Constrói validade interna, eleva o nível teórico } \\
\text { e aperfeiçoa as definições do construto. }\end{array}$ \\
\hline Fechamento & $\begin{array}{l}\text { - Saturação teórica quando } \\
\text { possível. }\end{array}$ & $\begin{array}{l}\text { - Finaliza o processo quando a evolução } \\
\text { marginal se torna mínima. }\end{array}$ \\
\hline
\end{tabular}

FONTE: EISENHARDT (1989, p. 533)

Eisenhardt (1989, p. 535) apresenta diversos exemplos de estudos em Administração nos quais foi utilizado método do estudo de casos. Na enorme maioria foram utilizados estudos de múltiplos casos. O número de casos variou entre seis e dez organizações. Em todas as situações, a fonte de dados foram entrevistas, combinadas com pelo menos mais uma fonte.

Kaplinsky e Morris (2003, p. 49-50) afirmam que a metodologia para pesquisas que utilizam abordagem da cadeia de valor tem início com a compreensão da natureza dos mercados finais. 
Estes mercados são, de forma crescente, o impulsionador de muitas cadeias de valor. Na abordagem da cadeia de valor, são propostos os seguintes temas:

- O ponto de entrada para a análise da cadeia de valor.

- Mapeamento das cadeias de valor.

- Segmentos de produto e fatores críticos de sucesso nos mercados finais.

- Como produtores têm acesso aos mercados finais.

- Comparação (benchmarking) de eficiência produtiva.

- Governança de cadeias de valor.

- Aperfeiçoamento competitivo em cadeias de valor.

- Questões distribucionais.

Os estudos que utilizam a abordagem da cadeia de valor dificilmente abordam todos estes temas. Esta pesquisa não avança na questão da comparação da eficiência produtiva. Os itens restantes, em graus variados, estão contemplados.

No caso da investigação em tela, em termos do ponto de entrada na cadeia de valor, pretendese utilizar um dos três seguintes pontos: (1) Principais produtores (Casos A1, A2 e A3). (2) Sub - fornecedores (Caso B1). (3) Pequenas empresas (Casos C1 e C2). As empresas B2 e B3 também podem ser considerados um tipo de sub-fornecedor, mas a B1 é o representante mais típico desta categoria. Kaplinsky e Morris (2003, p. 50-51) listam dez possíveis pontos de entrada com as respectivas indicações do que deve ser mapeado e exemplos. O quadro 11 a seguir traz estes aspectos relacionados aos três pontos escolhidos. 
Quadro 11 - Possíveis pontos de entrada na cadeia de valor

\begin{tabular}{|c|c|c|}
\hline $\begin{array}{l}\text { PRINCIPAL } \\
\text { ÁREA } \\
\text { DE PESQUISA }\end{array}$ & $\begin{array}{l}\text { PONTO DE } \\
\text { ENTRADA }\end{array}$ & $\begin{array}{l}\text { O QUE } \\
\text { MAPEAR }\end{array}$ \\
\hline $\begin{array}{l}\text { Papel dos } \\
\text { principais } \\
\text { produtores }\end{array}$ & $\begin{array}{l}\text { Grandes } O E M \text { s que montam produtos } \\
\text { finais. }\end{array}$ & $\begin{array}{l}\text { Ligações à frente com varejista, } \\
\text { para trás com fornecedores e } \\
\text { os fornecedores deles. }\end{array}$ \\
\hline $\begin{array}{l}\text { Fornecedores de } \\
\text { primeiro nível }\end{array}$ & $\begin{array}{l}\text { Grandes empresas que provêem montagens } \\
\text { intermediárias para os OEMs. }\end{array}$ & $\begin{array}{l}\text { Ligações à frente com os OEMs } \\
\text { e seus clientes, talvez em mais } \\
\text { de um setor. Para trás com } \\
\text { fornecedores e os fornecedores } \\
\text { deles. }\end{array}$ \\
\hline $\begin{array}{l}\text { Fornecedores de } \\
\text { segundo e terceiro } \\
\text { nível }\end{array}$ & Pequenas empresas de modo geral. & $\begin{array}{l}\text { Ligações à frente com clientes em uma } \\
\text { variedade de setores. Para trás com } \\
\text { fornecedores e os fornecedores } \\
\text { deles. }\end{array}$ \\
\hline $\begin{array}{l}\text { Pequenas } \\
\text { empresas }\end{array}$ & Pequenas e médias empresas. & $\begin{array}{l}\text { Compradores em redes de valor variadas, } \\
\text { fornecedores de insumos. }\end{array}$ \\
\hline
\end{tabular}

FONTE: KAPLINSKY; MORRIS, 2003, p. 51

Kaplinsky e Morris (2003, p. 53-56) recomendam que, uma vez identificada a cadeia de valor em questão, sua análise irá se beneficiar da construção do que chamam de uma árvore de relacionamentos insumos-produtos que incluem informações como:

- $\quad$ Valores comercializados.

- $\quad$ Fluxos ao longo da rede.

- $\quad$ Destino das vendas.

Com relação aos segmentos de produtos e fatores críticos de sucesso (FCSs), uma das características dos sistemas contemporâneos é que eles tendem a ser dirigidos pelo mercado, em comparação com as cadeias de valor características das décadas anteriores, que eram dirigidas pelos fornecedores e protegidas, além da pouca competição. Por esta razão, as características dos mercados de produtos finais são importantes nas cadeias de valor analisadas. No mínimo, isto requer um mapeamento do tamanho e das taxas de crescimento dos mercados estudados, o que foi feito no presente trabalho. 
Os mercados globais contemporâneos teriam uma série de características-chave que devem ser analisadas para que se compreenda a dinâmica da cadeia de valor. Os componentes críticos seguem:

- $\quad$ Segmentação.

- $\quad$ FCSs distintos para cada um dos segmentos.

\section{6 - Limitações metodológicas}

Schmitz e Knorringa (1999, p. 13) entendem que a desagregação da competitividade é fundamental para o êxito metodológico. A entrevista de compradores globais, no entanto, é qualificada como de uso limitado para a determinação das causas das forças e fraquezas dos fornecedores. Também se reconhece a subjetividade da escala de Liekert, no entanto ela se justifica pela necessidade de julgamentos comparativos.

Quanto às entrevistas, Yin (1994, p. 72) nota que se a unidade de análise do caso são organizações, as conclusões não podem somente estar baseadas em entrevistas, visto que esta fonte de informação traz como os indivíduos percebem a organização, mas não a organização em si. Embora as conclusões no presente estudo tenham sido baseadas em mais do que uma fonte de informações, as entrevistas desempenharam um papel fundamental na coleta de dados. Também as entrevistas, mesmo que fossem isentas, no presente estudo apresentam viés. A razão é que o relacionamento das empresas estudadas nas cadeias foi examinado somente a partir de sua própria perspectiva, isto é, não foram consultadas outras partes.

Stake (1995, p. 45-46) observa os problemas relacionados aos estudos de caso qualitativos. A primeira nota diz respeito à subjetividade da pesquisa qualitativa. Novos enigmas são produzidos com mais freqüência do que são elucidados os já existentes. Suas contribuições ao avanço da ciência disciplinada tendem a ser lentas e tendenciosas. Os riscos éticos são substanciais. Contudo, o propósito dos pesquisadores qualitativos é promover um paradigma subjetivo. A subjetividade não é percebida como uma falha a ser eliminada, mas como um elemento interpretativo essencial. As interpretações falhas ocorrem devido ao fato dos pesquisadores não serem conscientes de suas limitações intelectuais e devido às falhas metodológicas, que trazem consigo as distorções de julgamento. O procedimento de 
triangulação se aproxima do que é feito nas pesquisas quantitativas, embora os protocolos de pesquisa qualitativa não tragam rigor suficiente às interpretações subjetivas para evitar as distorções.

Eisenhardt (1989, p. 538) nota que nas situações em que múltiplos pesquisadores estão envolvidos, isto permite que o caso seja analisado sob múltiplas perspectivas. Portanto, a análise por um único pesquisador, que é o caso do presente estudo, se traduz em uma limitação que é preciso observar. 


\section{Capítulo 4 - DESCRIÇÃO DO SETOR E DOS CASOS ESTUDADOS}

\section{1 - O setor estudado}

Giuliani et al (2005, p. 554), baseados nas noções fundamentais de Pavitt, identificaram quatro grupos setoriais principais para a América Latina. Esta classificação se fundamentou na maneira pela qual ocorre o aprendizado e o aperfeiçoamento competitivo e, também, a organização industrial que prevalece no setor. A categoria dos fornecedores especializados, na qual podem ser classificados os casos estudados, é um desses quatro grupos setoriais, cujas características são apresentadas a seguir:

- $\quad$ Fornecedores especializados, nos casos estudados por Giuliani et al (2005, p. 554), essencialmente software. Esta é uma indústria tipicamente impulsionada pelos clientes. Este seria um setor especialmente promissor para as PMEs dos países em desenvolvimento, devido aos baixos custos físicos e de transporte e ao fato de ser um setor com alta intensidade de informação, o que modera a importância da proximidade dos mercados finais e amplia o escopo para uma divisão internacional do trabalho mais profunda. No entanto, ao mesmo tempo, a proximidade do mercado pode aperfeiçoar, de forma crucial, o desenvolvimento de capacitação em design e, portanto, incrementar o aperfeiçoamento de produtos e processos. Desta forma, neste setor coexistem pressões poderosas para o agrupamento (clustering) e para a globalização.

Lester (2003, p. 4-7), no caso de TI, argumenta que este é um dos mais importantes de economias desenvolvidas, como a dos EUA. Também é considerado um setor no qual a modularidade da cadeia de valor e dispersão geográfica avançaram mais. Ao nível do produto das empresas de TI, tem havido segmentação. O setor agora seria dominado por dois tipos de empresas: (1) As chamadas líderes, que tem foco em desenvolvimento de marcas e produtos, marketing, distribuição e serviços de pós-vendas. (2) O grupo de empresas contratadas cuja atividade foca na venda, como prestação de serviços, em muitas das atividades que as líderes decidiram terceirizar. Sobre as conseqüências geográficas desta modularidade, tem havido a diminuição das barreiras à entrada para novas empresas e aberto novas oportunidades para partes do mundo previamente na periferia de setores que se tornaram globais, como o de eletrônicos. 
Dedrick e Kraemer (1998, p. 13) avaliam que houve nas últimas décadas uma enorme alteração na estrutura do setor de informática: da freqüente integração vertical existente no tempo dos mainframes, para uma estrutura setorial descentralizada na atualidade, que se baseia nas chamadas economias de rede.

O mercado mundial de TI, de acordo com o International Data Corporation (IDC, 2006) citado pela Associação Brasileira de Software (ABES, 2007), movimentou, no ano de 2006, cerca de US\$ 714 bilhões, excluindo hardware. Se for incluído o item hardware, o total chega a US\$ 1,170 trilhão. Os EUA representam mais de 40\% deste total. Os quinze países que lideram a movimentação de TI no mundo representaram aproximadamente $90 \%$ do total no ano de 2006.

O mercado brasileiro de software e serviços ocupou a $13^{\mathrm{a}}$ posição no mercado mundial, tendo movimentado em 2006 aproximadamente 9,09 bilhões de dólares, equivalentes a 0,97\% do Produto Interno Bruto daquele ano. Deste total, foram movimentados US\$ 3,26 bilhões em software, o que representou perto de $1,3 \%$ do mercado mundial e $43 \%$ do mercado latino americano. Os restantes US\$ 5,83 bilhões foram movimentados em serviços de TI relacionados. Se for somada a movimentação com hardware a estes números, o total brasileiro chega a US\$ 16,2 bilhões.

O IDC (2008) indica que o crescimento na movimentação financeira em TI no Brasil irá resistir à recessão nos EUA, com um crescimento previsto para 2008 acima de 12\%, em comparação com um número entre 5 e 6\% nos EUA e na parte ocidental da União Européia. Há atividades, como, por exemplo, a chamada de BPM (Business Process Management) que evoluem a taxas altíssimas: o crescimento no Brasil em 2008, comparado com 2007 está estimado em 71\%. Outro impulsionador do crescimento do marcado de TI é a prática conhecida como offshoring. Embora o crescimento desta prática já traga conseqüências no mercado de trabalho do Brasil - na forma de escassez de oferta e salários mais altos, mesmo com a moeda brasileira apresentando valorização nos últimos cinco anos, o Brasil continua sendo considerado como um destino. Com estes eventos relatados há a tendência de contratação das empresas brasileiras para serviços de TI mais sofisticados (IDC, 2008). 
Portanto, como é possível visualizar na tabela 2, que segue, as atividades de software e serviços de TI, se somadas, representam mais de $60 \%$ do total do mercado brasileiro.

Tabela 2 - Detalhamento da movimentação financeira de TI no Brasil

\begin{tabular}{|c|c|c|c|}
\hline ATIVIDADE & HARDWARE & SOFTWARE & SERVIÇOS \\
\hline Participação na movimentação financeira total & $38,8 \%$ & $20,9 \%$ & $40,3 \%$ \\
\hline
\end{tabular}

FONTE: ABES (2007) com informações do IDC (2007)

A tabela 3, na seqüência, apresenta os dados relativos a software e serviços de TI. Como pode ser observado, em software mais de $67 \%$ do volume é desenvolvido no exterior, ao passo que em serviços, as atividades para o mercado local são enorme maioria (IDC, 2006, citado pela ABES, 2007). Em ambos os casos, a atividade para exportação é mínima, não chegando em nenhuma situação a 5\% do total da atividade. Contudo deve ser observado que a exportação de serviços supera a exportação de software (US\$ 195 milhões para serviços, que correspondem a 3,4\% do total em comparação a US\$ 52 milhões para software, que correspondem a 1,5\% do total deste item).

Tabela 3 - Software e serviços no Brasil em 2006

\begin{tabular}{|l|c|c|}
\multicolumn{1}{c|}{ ATIVIDADE } & $\begin{array}{c}\text { VOLUME } \\
\text { (US\$ milhões) }\end{array}$ & $\begin{array}{c}\text { PARTCIPAÇÃo } \\
\text { (\%) }\end{array}$ \\
\hline Desenvolvido no exterior & 2.202 & 67,5 \\
\hline Produção local sob encomenda & 760 & 23,3 \\
\hline Produção local padronizada & 252 & 7,7 \\
\hline Produção local para exportação & 52 & 1,5 \\
\hline \multicolumn{1}{c|}{ Subtotal software } & $\mathbf{3 . 2 6 0}$ & $\mathbf{1 0 0}$ \\
\hline Serviços mercado local & 5.635 & 96,6 \\
\hline Serviços exportação & 195 & 3,4 \\
\hline Subtotal serviços & $\mathbf{5 . 8 3 0}$ & $\mathbf{1 0 0}$ \\
\hline
\end{tabular}

FONTE: ABES (2007) com informações do IDC (2007) 
Com relação às categorias de produtos existentes no mercado brasileiro, a visualização da tabela 4, em seguida, permite a compreensão dos volumes movimentados em cada uma.

Tabela 4 - Categorias de produtos em software e serviços no Brasil com volumes movimentados

\begin{tabular}{|c|c|c|}
\hline ATIVIDADE & $\begin{array}{l}\text { VOLUME } \\
\text { (US\$ milhões) }\end{array}$ & $\begin{array}{c}\text { PARTICIPAÇÃO } \\
(\%)\end{array}$ \\
\hline Aplicativos & 736 & 22,6 \\
\hline Ambientes de desenvolvimento & 959 & 29,5 \\
\hline Infra-estrutura & 753 & 23,2 \\
\hline Software sob encomenda & 960 & 23,3 \\
\hline Software para exportação & 52 & 1,5 \\
\hline Subtotal software & 3.260 & 100 \\
\hline Consultoria & 991 & 17 \\
\hline Integração de sistemas & 1.050 & 18 \\
\hline Outsourcing & 2.506 & 43 \\
\hline Suporte & 1.050 & 18 \\
\hline Treinamento & 233 & 4 \\
\hline Subtotal serviços & 5.830 & 100 \\
\hline $\begin{array}{c}\text { TOTAL } \\
\text { SOFTWARE + SERVIÇOS }\end{array}$ & 9.090 & $--\mathrm{X}--$ \\
\hline
\end{tabular}

FONTE: ABES (2007) com informações do IDC (2007)

\section{2 - Os casos estudados}

Foram estudados oito casos cujo perfil pode ser examinado no quadro 12 que segue ${ }^{5}$. Todas as empresas estudadas atuam em TI, no segmento organizacional. As empresas nomeadas de A1, A2 e A3 são empresas voltadas para a produção e comercialização de softwares de gestão. A empresa A3, além de ser especializada em softwares de gestão para o varejo, obtém parte importante da sua receita da comercialização de equipamentos de automação comercial. Há

\footnotetext{
${ }^{5}$ Em função compromisso firmado com as empresas estudadas e os executivos entrevistados, os nomes das empresas estudadas não são divulgados.
} 
software embarcado nestes equipamentos, cuja venda está incluída nos números apresentados pela empresa ${ }^{6}$. As empresas nomeadas de B1, B2 e B3 são prestadoras de serviços de TI. As empresas B2 e B3 estão entre as líderes na atividade no Brasil e se encontram em processo de abertura de capital, bem como a empresa C1, que embora de reduzido porte em relação as demais estudadas, já conta com fundo de investimentos e banco estatal de fomento no seu quadro de acionistas. A empresa B1 é ligada a uma empresa de prestação de serviços, referência em termos de gestão e controle societário inovadores. As empresas C1 e C2 são especializadas em softwares de gestão para o setor financeiro.

\section{Quadro 12 - Perfil dos casos estudados}

\begin{tabular}{|c|c|c|c|c|}
\hline EMPRESA & $\begin{array}{c}\text { FAIXA DE } \\
\text { RECEITA ANUAL }\end{array}$ & $\begin{array}{l}\text { FOCO DE } \\
\text { ATUAÇÃO }\end{array}$ & $\begin{array}{l}\text { ESTADO DE } \\
\text { ORIGEM } \\
\end{array}$ & $\begin{array}{c}\text { FORMA } \\
\text { SOCIETÁRIA }\end{array}$ \\
\hline A1 & $\begin{array}{l}\text { Entre } \mathrm{R} \$ 150 \text { e R\$ } \\
500 \text { milhões }\end{array}$ & $\begin{array}{c}\text { Softwares de gestão para empresas } \\
\text { médias e grandes }\end{array}$ & SC & Capital aberto \\
\hline A2 & $\begin{array}{c}\text { Entre } \mathrm{R} \$ 150 \text { e R\$ } \\
500 \text { milhões }\end{array}$ & $\begin{array}{c}\text { Softwares de gestão para pequenas } \\
\text { e médias empresas }\end{array}$ & SP & Capital aberto \\
\hline A3 & $\begin{array}{l}\text { Entre } \mathrm{R} \$ 150 \text { e R\$ } \\
500 \text { milhões }\end{array}$ & $\begin{array}{l}\text { Automação comercial (hardware e } \\
\text { software) para varejo }\end{array}$ & PR & Capital aberto \\
\hline B1 & $\begin{array}{l}\text { Entre } \mathrm{R} \$ 150 \text { e } \mathrm{R} \$ \\
500 \text { milhões }\end{array}$ & Serviços de TI & SP & SA \\
\hline B2 & $\begin{array}{l}\text { Entre } \mathrm{R} \$ 150 \text { e R\$ } \\
500 \text { milhões }\end{array}$ & Serviços de TI & RGS & SA \\
\hline B3 & $\begin{array}{c}\text { Acima de R } \$ 500 \\
\text { milhões }\end{array}$ & Serviços de TI & SP & SA \\
\hline C1 & $\begin{array}{l}\text { Menor que R\$ } 60 \\
\text { milhões }\end{array}$ & $\begin{array}{l}\text { Softwares de gestão para o setor } \\
\text { financeiro }\end{array}$ & SP & SA \\
\hline C2 & $\begin{array}{l}\text { Menor que R\$ } 60 \\
\text { milhões }\end{array}$ & $\begin{array}{l}\text { Softwares de gestão para o setor } \\
\text { financeiro }\end{array}$ & SP & SA \\
\hline
\end{tabular}

Com relação à classificação das empresas estudadas, de acordo com o Instituto Brasileiro de Geografia e Estatística (IBGE, 2001, p. 17-19) não há unanimidade sobre a delimitação dos segmentos empresariais. Na prática, podem ser observados variados critérios para a classificação de empresas, seja na legislação, sejam nas instituições financeiras oficiais, seja nos órgãos representativos dos setores, que ora se baseiam no valor do faturamento, ora no

\footnotetext{
${ }^{6}$ Os números da ABES (2007) mencionados para o mercado brasileiro não consideram os softwares embarcados em hardware (ABES, 2007).
} 
número de pessoas ocupadas, ora em ambos. A utilização de conceitos heterogêneos decorre do fato a finalidade e os objetivos das instituições que promovem seu enquadramento são distintos (regulamentação, crédito, estudos, etc.). O critério da classificação por número de pessoas ocupadas é criticado por não levar em conta a distinção de processos produtivos e presença de mão-de-obra qualificada. É sugerido que pequenas empresas têm entre 6 e 19 pessoas ocupadas e que médias e grandes empresas têm mais de 20 pessoas ocupadas. Por este critério, todas as empresas estudadas seriam médias ou grandes. Também, é validado o critério do Banco Nacional de Desenvolvimento Econômico e Social (BNDES) para a classificação das empresas por porte.

Portanto, segue no quadro 13 a classificação das empresas estudadas conforme o critério do BNDES (2008):

Quadro 13 - Classificação das empresas estudadas por porte

\begin{tabular}{|l|c|c|}
\hline \multicolumn{1}{|c|}{ PORTE } & $\begin{array}{c}\text { RECEITA OPERACIONAL BRUTA } \\
\text { ANUAL OU ANUALIZADA }\end{array}$ & $\begin{array}{c}\text { EMPRESAS ESTUDADAS NA } \\
\text { CATEGORIA }\end{array}$ \\
\hline MICRO & Até 1,2 milhão & NENHUMA \\
\hline PEQUENA & De R\$ 1,201 milhão a R\$ 10,5 milhões & NENHUMA \\
\hline MÉDIA & De R\$ 10,501 milhões a R\$ 60 milhões & C1 e C2 \\
\hline GRANDE & Superior a R\$ 60 milhões & A1, A2, A3, B1, B2 e B3 \\
\hline
\end{tabular}

FONTE: AUTOR (2008) com critérios divulgados pelo BNDES (2008).

Contudo, este critério de classificação deve ser considerado com cautela. Primeiro, pelo fato de haver diferenças entre duas organizações com receita de, por exemplo, de R\$ 65 milhões e de R\$ 700 milhões. Segundo, porque as empresas C1 e C2, embora de porte reduzido, de acordo com as informações coletadas são representativas nos segmentos em que atuam. Os entrevistados nestas empresas observaram que uma empresa com operações no segmento de US\$ 30 milhões pode ser considerada de grande porte em termos internacionais.

\subsection{1 - Empresa A1}

A empresa está sediada no estado de Santa Catarina, na região Sul do Brasil. Considera-se pioneira no desenvolvimento e comercialização de soluções integradas de softwares de gestão 
empresarial, com quase 30 anos de atuação. Os softwares desenvolvidos pela empresa destinam-se a automatizar e gerenciar processos críticos em finanças, gestão de pessoas, logística, manufatura, entre outros.

A organização em 1999 implantou um modelo de franquias para desenvolvimento e comercialização de seus produtos. Neste processo, centenas de colaboradores da organização foram transformados em empreendedores, segundo definição da própria empresa. De acordo com o relatório anual de 2007, a rede de colaboradores da empresa é de aproximadamente 3,4 mil profissionais. Neste modelo de gestão, a empresa funciona como um centro de decisões, baseado em desenvolvedores especializados de software e canais de distribuição indiretos de ampla cobertura nacional e atuação internacional. No centro de decisões, também de acordo com o mesmo relatório, trabalham 155 profissionais.

O objetivo declarado da empresa é continuar como empresa líder em softwares de gestão empresarial integrada para organizações de médio e grande porte. Também, um dos objetivos específicos é ampliar a rede de distribuição e crescer na América Latina. A empresa cita uma pesquisa do IDC (2006), na qual sua participação corresponderia a 17,1\% do mercado total de licenças de uso e de manutenção de softwares de back office comercializados no Brasil em 2005.

A empresa informa que desenvolve seus softwares utilizando plataformas tecnológicas de empresas reconhecidas internacionalmente, como IBM, Microsoft, ADOBE e PROGRESS. Também, declara possuir aproximadamente 2,3 mil clientes ativos em vários setores da economia. Embora com grandes clientes, suas vendas são pulverizadas: os 100 maiores clientes representaram em 2005 31\% da receita líquida total e o maior cliente 1,1\% deste mesmo total.

Entre seus pontos fortes, a empresa avalia que oferece uma das melhores soluções disponíveis no mercado latino-americano, que foi desenvolvida especialmente para atender às características culturais, legais e locais de seus clientes.

A empresa conta com certificações como o ISO 9001 e utiliza como referência para os processos de desenvolvimento e manutenção de software o Capability Maturity Model Integration (CMMI). 
De acordo com informações divulgadas pela empresa, sua receita operacional bruta para o ano de 2007 se encontra em aproximadamente R 240 milhões, o que significou um crescimento superior a $27 \%$ em relação ao ano anterior. O lucro operacional antes dos resultados financeiros e da depreciação (LAJIRDA), na mesma base de comparação, cresceu quase 90\%, chegando a R\$ 37,9 milhões. A empresa possui capital aberto no Novo Mercado da BOVESPA, com mais de 65 \% do total de ações em circulação. Seu valor de mercado em 31/12/2007 superava a marca de R 500 milhões.

A empresa divulgou no seu relatório anual de 2007 que investiu na internacionalização neste ano cerca de R\$ 8 milhões em aquisições, integração, marketing e outros. O principal destino do investimento foi a inauguração de centro na Argentina, que responde pelo desenvolvimento e manutenção das adaptações para os países de língua hispânica, bem como toda a atividade de consultoria e atendimento para estes países. A receita líquida da empresa, com origem no exterior, alcançou R\$ 5 milhões, ou seja, pouco mais de 2,2\% do total de vendas na mesma base. A empresa declara estar em um momento de construção da base para um crescimento ainda mais acelerado nas operações externas, através da estruturação de canais e equipes, que no exterior contam com quase 200 profissionais.

Em 2008, a empresa continuou investindo no exterior, tendo divulgado a abertura de três franquias comerciais na Colômbia. Também, estuda a abertura de mais duas franquias comerciais em 2009, além de desenvolver estudos para a instalação de uma franquia de desenvolvimento de software neste país.

Em relação a P\&D, a empresa menciona no relatório anual de 2007, que segue investindo mais de $12 \%$ de sua receita líquida anual neste item. Este número significa, no ano mencionado, um montante de aproximadamente $\mathrm{R} \$ 28$ milhões em um crescimento perto de $40 \%$ sobre o ano anterior.

\subsection{2 - Empresa A2}

A empresa está instalada na cidade de São Paulo, estado de São Paulo. De acordo com o Relatório da Administração do ano de 2007, a organização se considera líder na atividade de desenvolvimento e comercialização de softwares de gestão empresarial integrada e na 
prestação de serviços relacionados, para o segmento de empresas de médio e pequeno porte no Brasil e na América Latina. Se considerada sua origem como bureau de serviços ao final da década de 60, são quase 40 anos de atuação, dos quais 25 como desenvolvedora de softwares. A empresa divulga que, no Brasil, conquistou mais de 50\% de participação do mercado de ERP (Enterprise Resource Planning, termo em inglês para Sistemas Integrados de Gestão), enquanto que na América Latina sua participação de mercado é de 22\%.

Segundo informações disponibilizadas ao mercado, a empresa A2 é uma das 15 maiores do mundo em softwares de gestão, contando com destacado crescimento nas vendas em comparação com as demais da lista. Na América Latina é uma das cinco maiores com maiores companhias na atividade.

De acordo com informações obtidas junto à própria companhia, esta contava em setembro de 2007 com mais de três mil funcionários, contratados sob o regime da Consolidação das Leis do Trabalho (CLT).

A organização possui certificação ISO 9001 desde 1996. Em 2001, todas as franquias da empresa obtiveram certificação nas normas ISO 9002. Em 2005, foi obtida a certificação CMMI, nível 2, em duas das divisões da organização.

Com relação às operações internacionais, a primeira unidade no exterior foi inaugurada em 1997 na Argentina. Ainda de acordo com informações divulgadas pela própria empresa, há presença geográfica em sete países (Argentina, Bolívia, Chile, México, Paraguai, Portugal e Porto Rico). Em 2007 foi criada a Diretoria de Expansão Internacional para ampliar o ritmo de desenvolvimento de negócios fora do país de origem. Os produtos da empresa estão disponíveis também em inglês e espanhol, além do português (duas versões, para o Brasil e Portugal).

Também, foi divulgado e confirmado nos contatos realizados que a organização conta com sistema de distribuição composto por unidades próprias e franquias.

A empresa menciona em sua comunicação oficial que possui mais de 15 mil clientes ativos de diversos setores da economia. Os 10 maiores clientes representam 4\% das vendas e os 100 maiores clientes $17 \%$. 
A organização acredita ser a única empresa latino-americana que desenvolveu e é titular de plataforma tecnológica própria para softwares, o que lhe propicia flexibilidade, interface com diferentes softwares, redes, bancos de dados e outros; e independência na escolha de plataforma, topologia, conexão e base de dados. Adicionalmente, é declarado que a linha de produtos compreende soluções para as diversas necessidades na automação de processos de gestão, como, por exemplo, os softwares ERP, CRM (Customer Relationship Management), BI (Business Intelligence), SCM (Supply Chain Management) e os módulos verticais.

A companhia tem sido reconhecida por entidades de notória reputação no Brasil e no exterior com diversos prêmios nacionais e internacionais, quanto aos seus procedimentos relacionados à governança corporativa, gestão de pessoas e criação de negócios inovadores.

No tocante à receita operacional bruta, foi divulgado que esta atingiu no ano de 2007 aproximadamente R\$ 490 milhões, representando um crescimento pouco inferior a $17 \%$ em comparação com o ano de 2006. O LAJIRDA foi de aproximadamente R\$ 96 milhões em 2007, com crescimento superior a 36\% quando comparado a 2006. A empresa possui capital aberto no Novo Mercado da BOVESPA, com aproximadamente 55\% do total de ações em circulação. Um banco estatal de fomento e alguns fundos internacionais possuem, se somadas suas respectivas participações, em torno de $25 \%$ do seu capital. O valor de mercado da empresa em abril de 2008 superava R\$ 1 bilhão.

\subsection{3 - Empresa A3}

A empresa tem sede no estado do Paraná, região Sul do Brasil. É declarado que atende o mercado com soluções completas em automação comercial. Fundada no início da década de 1990, tendo como origem os bancos da universidade e posteriormente uma incubadora, a organização informa ter vendido equipamentos e softwares para automação comercial, na década de 2000, para 350 mil clientes finais no Brasil. Também, foi em meados da década de 2000 que a empresa passou a comercializar serviços e software. Os serviços prestados pela empresa compreendem suporte técnico e manutenção. Hoje os equipamentos, que possuem software embarcado, respondem por aproximadamente $70 \%$ da receita. Os serviços são aproximadamente $20 \%$ e os softwares, $10 \%$ da receita total. Em software, a empresa, baseada em estudos de terceiros, divulga ser líder no licenciamento, com 9\% dos aplicativos para 
gestão do comércio. O crescimento em software e serviços está entre os objetivos estratégicos deste caso estudado. Também, informa deter participação de mercado acima de 60\% nos checkouts de estabelecimentos automatizados no Brasil em 2006.

A empresa ambiciona querer ser a maior empresa do mundo em automação comercial para o pequeno e médio varejo até 2015. Uma vantagem competitiva desta entidade é o domínio dos projetos dos produtos que vende. Para manter esta vantagem, os comunicados da empresa mencionam os investimentos em P\&D, que compreendem laboratório e centro de pesquisa de classe mundial para automação comercial. Também, há menção aos investimentos em treinamento, que incluem a criação de uma universidade corporativa na década de 2000.

Quanto às operações internacionais, desde o início da década de 2000 são realizadas exportações para países desenvolvidos. Em 2007, a atuação internacional foi fortalecida com a inauguração das subsidiárias em Buenos Aires na Argentina e em Berlim na Alemanha. Esta última filial tem como objetivo ampliar os canais comerciais na Europa e em países como o Paquistão e a Índia. A companhia possui, já incluídas as recém inauguradas, quatro subsidiárias no exterior (EUA, Argentina, Alemanha e Taiwan). Algumas destas filiais são focadas em procurement (termo em inglês para abastecimento, compras, realizados de maneira planejada) e no acompanhamento de tendências para o mercado de automação comercial para o varejo. Na América Latina foram realizadas parcerias com empresas de software. A empresa possui produtos homologados no Chile, Venezuela e Argentina. Já foram realizadas vendas para todos os países da América Latina.

Documentos disponibilizados ao mercado pela empresa enfatizam o empenho na ampliação da atuação internacional, com a abertura de canais de comercialização onde ainda não opera. A meta é que até 2015, 15\% da receita seja obtida fora do Brasil. A previsão é que em 2008 se sejam obtidos US\$ 10 milhões de receitas no exterior. Há previsão de ocorrência de aquisição no exterior pela primeira vez, provavelmente na Argentina. Também se prevê a abertura de uma fábrica na Ásia e de um escritório no México. Para 2009 e 2010 as metas incluem compras de fabricantes de softwares na Europa e nos EUA. Os executivos da empresa fizeram périplos por oito países em 2007 para reforçar parcerias e consolidar a marca. A empresa conta hoje com 700 revendas na região. Este caso estudado tem sido citado como exemplo de organização que vem aproveitando as oportunidades oferecidas pela globalização, pois 
transferiu a criação e a fabricação de componentes para a Ásia, mantendo com lucro a distribuição e a venda de produtos.

A organização trabalha com um modelo híbrido de comercialização, do qual fazem parte distribuidores, revendas e representantes. Entre os destaques na atuação deste caso, está o seu envolvimento com o projeto das urnas eletrônicas do Tribunal Superior Eleitoral (TSE) do Brasil.

As vendas desta organização quadruplicaram de 1999 para 2006. Em 2007, a receita operacional bruta alcançou aproximadamente R\$ 290 milhões, com crescimento pouco abaixo de 22\% sobre 2006, levando em conta o resultado consolidado. O LAJIRDA em 2007 foi superior a R\$ 50 milhões. Este indicador cresceu a uma taxa média anual acima de 20\% nos últimos dois anos.

A empresa é de capital aberto no Novo Mercado da BOVESPA. Está constituída como sociedade por ações desde o início da década de 90, quando foram admitidos pelos fundadores alguns sócios investidores. Aproximadamente 60\% das ações da empresa estavam em circulação no primeiro trimestre de 2008. Ao redor de dez investidores que apoiaram a empresa no início ainda constam do quadro de acionistas no primeiro trimestre de 2008. Um banco estatal de fomento é acionista da empresa com menos de $10 \%$ de participação no capital, parcela semelhante àquela detida por cada um dos fundadores. Participam também do capital destacados fundos de investimentos com menos de $10 \%$ do capital total cada um. O valor de mercado da companhia em abril de 2008 superava R 300 milhões.

A empresa alega aderir a boas práticas de governança corporativa, tendo recebido prêmio por sua atuação neste quesito. Embora novata na BOVESPA, suas ações tem sido recomendadas por analistas de mercado.

\subsection{4 - Empresa B1}

A empresa B1 tem sede na cidade de São Paulo, estado de São Paulo. Trata-se de uma integradora de sistemas nos setores de telecomunicações e TI, de acordo com definição da própria entidade estudada. Atua há mais de três décadas, oferecendo serviços em telecomunicações que abrangem todas as etapas de um projeto, desde o planejamento, 
concepção e implantação dessas soluções, até a operação e manutenção das infra-estruturas. Em TI, a empresa declara apoiar seus clientes na integração de múltiplos sistemas e plataformas e no desenvolvimento de softwares customizados para as mais variadas aplicações, entre elas Sistemas de Suporte à Operação (OSS), Processos de Negócios (BSS) e para a Segurança da Informação e Armazenagem.

No mês de março de 2008, foi anunciada pela empresa a realização de uma fusão com uma empresa britânica, na qual foi criada uma organização de US\$ 250 milhões de faturamento anual - aproximadamente R\$ 400 milhões ao câmbio de R\$1,7 por US\$ 1 - que segundo divulgado, será a maior integradora independente da América Latina. A empresa brasileira estudada deterá 30\% da associação e a britânica 70\%. A empresa brasileira receberá uma compensação pela participação menor, em ações da britânica, que representam cerca de 4\% do capital desta última. Esta fusão está ligada à decisão de internacionalização tomada em 2006. A gestão da organização, embora com participação minoritária, será da brasileira. A fusão anunciada expandirá a capilaridade da empresa na região latino-americana, com quase 500 profissionais no Brasil, Argentina, Chile, Peru e Paraguai. O escopo da empresa que resulta da união com a empresa britânica terá como escopo geográfico a América Latina.

A empresa se configurou como uma rede, formando um ecossistema, que interliga grande variedade de participantes em diversas formas de colaboração. Esta organização se dedica à criação, consolidação e gestão eficiente desta rede, que tem como missão atender às demandas criadas por cada projeto.

Dentro do escopo de atividades inovadoras desenvolvidas por esta empresa, foi criado um instituto de tecnologia, que se propõe a ter a neutralidade necessária para analisar de forma imparcial e debater a aplicação de tecnologias emergentes, tendo também como objetivo a geração e difusão do conhecimento. Este instituto tem estabelecido convênios com institutos de cooperação com conceituados centros universitários e de pesquisa e desenvolvimento tecnológico no Brasil e no exterior. Este instituto edita publicação técnica periódica sobre temas relacionados às tecnologias emergentes de suas áreas foco. Também, este caso foi classificado como uma das 100 empresas mais inovadoras em TI, segundo estudo de publicação especializada no Brasil. 
A atuação da empresa é reconhecida internacionalmente: há aproximadamente dois anos foi selecionada para um grupo de 33 empresas utilizado como referência global para empresas de alto desempenho de importante consultoria multinacional. A empresa estudada é uma das duas empresas latino-americanas e a única brasileira neste grupo. A organização é reconhecida como uma das líderes mundiais no que se refere à gestão de pessoas.

A empresa tem estabelecido parcerias para atuação na América Latina. Sua expertise nesta região é desfruta de reputação global.

A organização conta com quase 100 profissionais certificados em gerenciamento de projetos, de um total de 200 funcionários nas suas sedes de São Paulo e do Rio de Janeiro. Na gestão de pessoas, esta organização tem sido contemplada com diversos prêmios, entre os quais se destaca o fato de estar presente quatro vezes nas dez edições da pesquisa intitulada "Melhores Empresas para se Trabalhar”. Também foi selecionada como destaque especial na lista das 100 Melhores Empresas para se Trabalhar na América Latina. Segundo declarações de seus dirigentes, no Brasil e no mundo há escassez de profissionais qualificados na área de engenharia.

Com relação a seu porte, a organização está entre uma das 100 maiores do ranking do Anuário Telecom, edição de 2006, com especial projeção na categoria serviços de consultoria, projeto e integração, para a qual foram avaliadas mais de 50 empresas. A receita bruta total anual desta organização foi de aproximadamente $\mathrm{R} \$ 300$ milhões, o que significou um crescimento sobre o ano anterior acima de 30\%. O LAJIRDA em 2007 foi de aproximadamente R 30 milhões. Com a fusão mencionada, a expectativa é que este valor alcance US\$ 500 milhões algo em torno de R\$ 800 milhões ao cambio de abril de 2008 - em três anos. A empresa estudada, previamente à fusão, fazia parte de um grupo - que continua como acionista representando cerca de $40 \%$ de seu faturamento.

\subsection{5 - Empresa B2}

Esta empresa foi fundada na segunda metade da década de 80, no estado do Rio Grande do Sul. Atualmente, parte importante da sua administração está estabelecida na cidade de São Paulo. Conta com 30 escritórios em 14 países e auferiu vendas superiores a R 350 milhões em 2007, com aproximadamente cinco mil funcionários. O crescimento, que no ano de 2007, 
comparado a 2006, foi de quase 15\%, tem sido acelerado: no ano 2000, esta organização obteve receitas brutas pouco menores do que R\$ 100 milhões. Sua origem está na prestação de serviços de treinamento. Ao longo do tempo, passou a realizar a terceirização de serviços para os clientes. A empresa já prestou serviços para quase mil clientes, dos quais mais de 400 se encontram ativos. O setor financeiro representa mais do que $30 \%$ do faturamento global da empresa. Setores como petróleo e de telecomunicações pesam ao redor de 15\% cada um na receita bruta. O setor governo representa entre mais de 6 \% dos negócios. O segmento de bancos e seguradoras é o que mais cresce. A divisão de outsourcing, representa cerca de $60 \%$ dos negócios deste caso estudado, bem à frente da divisão de consultoria, que tem peso de aproximadamente $20 \%$. O restante é referente às atividades de desenvolvimento e integração de sistemas. Os projetos de BPO (Business Process Outsourcing) têm merecido a atenção da entidade, pois há previsões de que cresça acima do mercado.

Sua estrutura de governança corporativa está preparada para a abertura de capital: em 2007 foi criado um Conselho de Administração, com a nomeação de membros independentes. Para a escolha dos membros do conselho, um dos critérios foi a experiência em comércio exterior. Os dirigentes da empresa estudada participam de um organismo criado a pedido dos governos do Brasil e dos EUA para sugerir medidas que contribuam para o incremento do comércio entre os dois países.

A empresa tem foco na prestação de serviços, isto é não atua com produtos próprios. Os serviços são prestados com produtos de terceiros. A atuação da empresa no Brasil e no exterior é baseada em alianças com organizações que complementem sua atuação. Este aspecto, bem como a abrangência geográfica de suas operações, é indicado pelos documentos divulgados pela empresa como vantagens em relação à concorrência. A certificação ISO 9001 foi obtida pela empresa em meados da década de 90.

Com relação às operações no exterior, em torno de $25 \%$ do total das operações da empresa vêm de fora do Brasil. A empresa mantém operações em 13 países: Argentina, Chile, Peru, Colômbia, Venezuela, México, EUA, Espanha, Portugal, Itália, Inglaterra, Índia e Angola. Todos os escritórios no exterior são próprios e a oferta de serviços é igual àquela feita no Brasil. No México foi inaugurado em 2007 o terceiro escritório. Neste país a organização atende quatro dos cinco maiores bancos e multinacionais que são referência no mercado mundial. Também no México, foi implantado em 2007 um centro de desenvolvimento de 
software. O mercado mexicano é importante em termos estratégicos, sendo um dos que mais crescem na companhia. Na atuação externa, a organização pretende crescer também por meio de aquisições. Foram citados pelos executivos em comunicados públicos da empresa, os EUA, Inglaterra e o México para aquisições no exterior. Fora do país a empresa emprega mais de 500 funcionários e mantém ao redor de outros 400 no país prestando serviços para fora. A operação na Índia, que existe desde 2006, teve divulgados investimentos da ordem de US\$ 100 milhões, com a contratação estimada em 100 profissionais.

A visão dos dirigentes da organização contempla metas ambiciosas: quer se tornar uma empresa com mais de US\$ 700 milhões de receita bruta até o ano de 2011, com a liderança na geração de valor, qualidade dos serviços e com crescimento sustentável. A empresa pretende alcançar estes números através da oferta de novos serviços aos clientes e da conquista de novos clientes.

A empresa na segunda metade da década de 2000 estabeleceu parcerias com instituições que são referência no país em termos de pesquisa, aplicação e ensino de tecnologia. Dentro do Âmbito de uma destas parcerias foi criado um curso no nível de pós-graduação em TI. A empresa também mantém uma fábrica de software dentro das instalações da universidade parceira no interior do estado de São Paulo.

\subsection{6 - Empresa B3}

A sede deste caso estudado está localizada na cidade de São Paulo. A organização está focada na oferta de soluções integradas de TI e BPO. A atividade de TI engloba infra-estrutura desta atividade e integração de sistemas. Sob o título $B P O$, estão os serviços de central de atendimento e as soluções para processos de negócios. Os administradores e acionistas da organização acreditam que se pode qualificá-la como líder na América Latina nas atividades que compõem sua oferta. Sua origem monta a empresas fundadas nos anos finais da década de 90 na cidade de São Paulo, focadas em BPO e serviços de infra-estrutura de TI. Ao longo destes anos, houve uma série de fusões, aquisições e ingresso de novos acionistas. $\mathrm{Na}$ atualidade, além dos fundadores das empresas que originaram a organização atual, há fundos de investimento e grandes grupos empresariais brasileiros participando do quadro societário. Há possibilidade de Oferta Pública de Ações da empresa na BOVESPA nos próximos anos. 
O segmento-alvo de atuação desta companhia estudada são as organizações de médio e grande porte dos setores financeiro, manufatura e serviços. Na atualidade, o número total de clientes supera a cifra de mil. O setor de maior peso é aquele composto por bancos, seguradoras e cartões de crédito, responsável por quase $60 \%$ da receita bruta. O setor de serviços de utilidade pública representa aproximadamente $25 \%$ da receita da empresa. O maior cliente da empresa detém participação na sua receita bruta que não chega a $10 \%$ do total. Os dez maiores clientes, se somada sua participação na receita bruta, representam ao redor de 60\% deste total. Embora ocorra a prestação de serviços a empresas controladas pela União e por estados da federação, os executivos da empresa entrevistados declararam que o setor governo, diretamente, não faz parte dos alvos da empresa. A organização resultante da fusão mais recente logrou obter receitas brutas de aproximadamente R\$ 700 milhões no ano de 2007. Este resultado significa um crescimento de $40 \%$ se comparado à receita bruta de 2006 das empresas que se fundiram para compor a companhia atual. Esta companhia pretende se manter em crescimento, com metas de atingir dois dígitos, através de crescimento orgânico, aquisições e internacionalização.

Os dirigentes e acionistas da empresa têm declarado publicamente que a internacionalização das atividades está entre as prioridades. De acordo com informações públicas divulgadas pelos executivos da empresa, cerca de 5\% do faturamento provêm de prestação de serviços a clientes no Canadá, EUA, América Latina e Europa. O objetivo é concorrer com os principais fornecedores do mundo, nas atividades que a entidade atua. A organização conta atualmente com quase 20 mil funcionários em quase 20 sítios por todo o Brasil.

$\mathrm{Na}$ gestão de pessoas, os executivos da organização têm declarado que são realizados investimentos, concretizados na parceria com instituições de ensino para a formação de profissionais, visto que há carência de pessoal especializado na atividade no Brasil. Estes investimentos contemplam também o apoio à evolução dos profissionais para funções mais sofisticadas (de operador de central de atendimento para programador e desenvolvedor de sistemas, por exemplo). São mais de 50 funcionários na organização envolvidos com a atividade de gestão de pessoas. A folha de pagamentos anual, incluindo remuneração, encargos sociais e benefícios, totaliza um número no intervalo entre R\$ 400 e R\$ 450 milhões. 
Informações públicas disponibilizadas pela empresa apontam que se trata da única companhia no Brasil com dois data centers "Nível Cinco”, o que garante alta disponibilidade para as operações críticas de TI aos clientes. Também é informado que a certificação CMMi de nível 3 foi obtida para a fábrica de software e se investe em processos e treinamento para chegar ao CMMi de nível 5 em maturidade de processo.

\subsection{7 - Empresa C1}

Esta empresa estudada foi fundada no ano de 1996 na cidade de São Paulo. Trata-se de uma entidade cuja oferta visa atender todas as necessidades do mercado financeiro quanto a produtos e serviços em tecnologia. De acordo com informações divulgadas por esta organização, esta se considera a líder nacional no desenvolvimento de softwares e serviços de TI para bancos e instituições financeiras. Suas soluções em tecnologia contemplam softwares, projetos, fábrica de software, consultoria e outros serviços. Está localizada a uma quadra a Avenida Paulista, centro financeiro da cidade, onde têm sede aproximadamente 40 bancos. No primeiro semestre de 2008, a empresa contava com aproximadamente 80 clientes, dentre eles os dez maiores bancos que atuam no Brasil. Em linha com a tendência do mercado de não cobrar a licença de uso antecipadamente, esta empresa estudada partiu para a disponibilização do software como serviço, com o fim de atrair clientes de menor porte. A entidade avalia que, com os conceitos presentes em seus aplicativos, atua no mercado brasileiro em aderência aos padrões internacionais.

A companhia resulta da fusão de várias empresas que desenvolviam e comercializavam soluções para o setor financeiro. Algumas destas empresas foram fundadas na década de 90, antes da que deu origem ao nome atual. Os nomes das empresas que se fundiram para compor a atual são utilizados para dar nome a unidades de negócios e produtos. A organização que resultou das fusões, iniciadas em 2004, conta hoje com 300 funcionários. Um fundo de capital de risco e um banco estatal de fomento possuem, em conjunto, entre 30 e $40 \%$ do capital da empresa. Há pelo menos uma entidade governamental que é investidora neste fundo de capital de risco. A companhia recebeu apoio governamental através do programa denominado PROSOFT (Programa para o Desenvolvimento da Indústria de Software e Serviços de Tecnologia da Informação) mais de uma vez. A empresa se prepara para a abertura de capital, no âmbito do BovespaMais da BOVESPA, segmento dirigido a empresas de menor porte. Segundo informações divulgadas ao mercado, será uma oferta primária e os recursos serão 
utilizados para aquisições, que terão como objetivo levar a organização a novos patamares em termos de porte. A oferta pública terá como objetivo colocar no BovespaMais ao redor de $20 \%$ do capital da organização.

Informações tornadas públicas pelos executivos da empresa dão conta de que a receita bruta da empresa no ano de 2007 foi de aproximadamente R\$ 30 milhões. Os números para este indicador em 2008, de acordo com as mesmas fontes, podem estar em um intervalo que vai de R\$ 60 a R\$ 80 milhões, se considerada a receita das empresas adquiridas. A empresa pretende multiplicar sua receita bruta por quatro até o ano de 2010. Nos últimos quatro anos, esta entidade estudada tem mantido crescimento médio anual da receita alto, cuja estimativa pode variar entre 35 e 75\%, dependendo da fonte consultada e do critério utilizado. Este caso estudado integra a lista das Pequenas e Médias Empresas (PMEs) que mais crescem no Brasil, em colocação de destaque, de acordo com o critério de expansão de sua receita entre os anos de 2004 e 2006. A atividade de avaliação de empresas para aquisição continua intensa: no segundo semestre de 2007, onze empresas eram examinadas com este objetivo.

A empresa atua internacionalmente com um produto voltado a seguradoras. O objetivo é atuar internacionalmente com as demais unidades de negócios / produtos. O diretor da unidade de negócio responsável pelos produtos voltados ao mercado segurador é o responsável pela atividade internacional. Este produto dirigido ao mercado segurador foi um dos primeiros a operar em ambientes web, hoje característica obrigatória para atuação com êxito no mercado internacional, de acordo com informações prestadas por executivos da organização. No primeiro semestre de 2008, a estimativa é que cerca de $10 \%$ da receita total da organização venha das vendas ao exterior. A meta é elevar esta participação para um número ao redor de $20 \%$ entre 2009 e 2010. Se considerado somente o produto voltado ao mercado segurador, de acordo com as informações disponibilizadas pela empresa ao mercado, a participação das vendas externas chega a 50\%. Deste total, a maior parte da receita externa tem origem na Índia e em países da Ásia. O fortalecimento da atuação internacional começará pela América Latina. Serão avaliadas duas formas de atuação internacional: através da aquisição de empresas e da parceria com organizações locais. Os planos para 2008 incluem o funcionamento de filiais na Argentina, no Chile e no México, por meio de parceiros locais. A comercialização do software como serviço é avaliada pelos executivos da empresa como impulsionadora da atuação internacional. 
A organização conta com parcerias importantes, uma delas com a Microsoft, onde faz parte de um seleto grupo de empresas certificadas no mais alto nível. As soluções da empresa também têm integrado, através de parcerias, produtos de empresas líderes no mundo em inteligência de negócios (do inglês, Business Intelligence, BI). No primeiro semestre de 2008 a organização celebrou acordo para trazer ao Brasil os produtos de uma das companhias que mais crescem na atividade de software no mercado norte-americano. A empresa objeto de estudo é considerada por parceiros internacionais como uma companhia consolidada com excelente desempenho no setor financeiro brasileiro. Há parceiros que declararam pretender utilizar a organização estudada como base para expansão na América Latina.

\subsection{8 - Empresa C2}

Esta empresa estudada foi criada em 1995 e está localizada em São Paulo devido ao enorme número de sedes corporativas existentes nesta cidade, segundo informado. Ainda controlada pelos fundadores, especialistas nos dois produtos desenvolvidos e comercializados, a empresa C2 atua com foco em soluções integradas de software e serviços para o gerenciamento eletrônico de documentos (GED) ou Enterprise Content Management (ECM, no inglês), nome e sigla pela qual a atividade é conhecida mundialmente. A atividade compreende a gestão de documentos e a automação de processos de negócios. A organização volta sua atuação para diversos mercados verticais, como por exemplo, bancos, seguradoras e hospitais. De acordo com documentos divulgados pela entidade objeto de estudo, o escopo de sua atuação é desenvolver ferramentas e estratégias que permitam a captura, o armazenamento, o gerenciamento, a preservação e uma distribuição que facilita o acesso aos dados, informações e documentos de uma organização, independente de onde e em que formato se encontra o conteúdo. O produto da empresa que é comercializado fora do Brasil recebeu homologação tecnológica por empresas internacionais de destaque e por órgãos ligados ao governo brasileiro.

A entidade possui entre 30 e 40 clientes. Seu faturamento anual se encontra abaixo de R\$ 30 milhões. A organização informa que bancos, seguradoras, empresas industriais e de serviços de origem brasileira e estrangeira, além de bureaux de serviços utilizam suas soluções no Brasil e no exterior. No Brasil, a atuação ocorre em nível nacional. Uma empresa industrial multinacional, após implementar a solução da empresa no Brasil, a passou a utilizá-la na Colômbia, Venezuela, Equador, Peru e Bolívia. Trata-se de uma operação internacional 
indireta que teve início há quatro anos. Há operações indiretas também através de clientes do setor financeiro, além da multinacional industrial, nas Bahamas e no Uruguai.

Com relação à atuação internacional direta, opera desta forma no México. Há planos de operar assim também na Europa. No México é utilizado canal de distribuição. A empresa avalia seu produto de GED como novo no Brasil e no mundo. São poucas empresas no mundo que oferecem uma solução completa como a desta organização, de acordo com declarações obtidas.

A entidade elaborou um planejamento com vistas aos próximos quinze anos. Neste planejamento estão refletidas as preocupações da empresa com tecnologia e evolução dos produtos. A utilização de canais de distribuição decorre da definição que se trata de uma empresa focada em tecnologia. Por esta razão, são utilizados canais indiretos, pois a organização não pretende se envolver na distribuição.

Como é comum em software, na implementação de seus produtos nos clientes, sempre ocorre uma adaptação, chamada no setor de customização. Esta adaptação ocorre em função da necessidade de adequação aos sistemas das instituições que compram o produto.

Um aspecto digno de nota na atuação desta empresa são as parcerias que mantém com multinacionais, em especial uma fabricante de equipamentos. A parceria tecnológica que existe com esta empresa se estende ao México. Foi informado que esta organização estudada é parceira da Microsoft para evolução tecnológica. A empresa tem feito aproximação com universidades com vistas ao desenvolvimento de parcerias.

A empresa segue realizando pesquisas de novos produtos. Nos produtos atuais até empresas como IBM e Xerox podem ser consideradas concorrentes deste caso estudado, segundo declarações obtidas junto a seus executivos. A organização ambiciona a liderança mundial na atividade de gestão de documentos.

A partir do ano de 2006, foi implantado um programa de investimento nas pessoas. A política para esta atividade foi alterada, com mudanças na forma de relacionamento, benefícios, investimentos em treinamento e um programa de participação nos resultados. Todos os colaboradores são contratados permanentemente, ou seja, não há contratos temporários com 
os funcionários. Encontra-se em discussão um plano de sucessão para os sócios-diretores, que são os que fundaram a empresa.

Também têm ocorrido transformações em P\&D. No segundo semestre do ano de 2007 houve a criação de uma Diretoria de Tecnologia e Novos Produtos, que é responsável pela atividade de pesquisa.

\section{3 - Proposta de classificação dos casos estudados}

Os casos estudados são classificados de acordo com a estrutura que segue, nos quadros 14, 15 e 16.

É possível inferir sobre o grau de sofisticação de uma estratégia empresarial através do exame dos indicadores apresentados no quadro 14, que segue: 
Quadro 14 - Indicadores da sofisticação da estratégia empresarial e respectivas razões

\begin{tabular}{|c|c|}
\hline $\begin{array}{l}\text { INDICADORES DA } \\
\text { SOFISTICAÇÃO DA } \\
\text { ESTRATÉGIA EMPRESARIAL }\end{array}$ & $\begin{array}{l}\text { RAZÕES PELAS QUAL O INDICADOR } \\
\text { SIGNIFICA MAIOR SOFISTICAÇÃO DA ESTRATÉGIA }\end{array}$ \\
\hline $\begin{array}{l}\text { Participação da empresa em mais de uma } \\
\text { cadeia. }\end{array}$ & $\begin{array}{l}\text { - A gestão da participação simultânea em várias cadeias exige } \\
\text { técnicas mais elaboradas de administração. } \\
\text { - Do ponto de vista da gestão da empresa, no curto prazo é mais } \\
\text { confortável estar conectado a somente uma cadeia. }\end{array}$ \\
\hline $\begin{array}{l}\text { Importância conferida aos resultados de } \\
\text { longo prazo. }\end{array}$ & $\begin{array}{l}\text { - Ações que trarão resultados no longo prazo exigem que os } \\
\text { administradores deixem de lado as pressões do dia a dia para se } \\
\text { concentrar no que é realmente importante para a empresa. } \\
\text { - O foco nos resultados de longo prazo significa, muitas vezes, a } \\
\text { renúncia aos de curto prazo. }\end{array}$ \\
\hline $\begin{array}{l}\text { Grau em que se contempla o } \\
\text { envolvimento na coordenação de } \\
\text { processos complexos de produção e } \\
\text { distribuição. }\end{array}$ & $\begin{array}{l}\text { - Muitas vezes, isto significa o envolvimento em processos que se } \\
\text { desenvolvem fora da empresa. }\end{array}$ \\
\hline $\begin{array}{l}\text { Grau de consciência quanto à } \\
\text { necessidade de aprender. }\end{array}$ & $\begin{array}{l}\text { - Exige reflexão e avaliação prévias e uma preparação superior para } \\
\text { que ocorra. }\end{array}$ \\
\hline $\begin{array}{l}\text { Importância conferida ao aprimoramento } \\
\text { contínuo. }\end{array}$ & $\begin{array}{l}\text { - Exige atenção permanente à estratégia e à evolução da } \\
\text { concorrência. }\end{array}$ \\
\hline $\begin{array}{l}\text { Grau em que as estratégias contemplam o } \\
\text { item inovação. }\end{array}$ & $\begin{array}{l}\text { - Dificuldade de desenvolvimento de inovações que não possam ser } \\
\text { rapidamente copiada pelos concorrentes e que possibilitam } \\
\text { rendimentos econômicos mais altos. }\end{array}$ \\
\hline $\begin{array}{l}\text { Grau e formas de internacionalização } \\
\text { contemplada pela estratégia empresarial. }\end{array}$ & $\begin{array}{l}\text { - Estratégias sofisticadas contemplam formas de internacionalização } \\
\text { mais elaboradas, como, por exemplo, a operação em outros países, o } \\
\text { investimento em itens como marcas e canais de distribuição fora do } \\
\text { país de origem etc. }\end{array}$ \\
\hline
\end{tabular}

No tocante às limitações existentes para a obtenção de rendimentos econômicos superiores, o quadro 15, exibido na seqüência, apresenta os indicadores propostos para a verificação da existência e do grau destas limitações. 


\section{Quadro 15 - Indicadores de limitações à obtenção de rendimentos econômicos superiores com respectivas razões}

\begin{tabular}{|c|c|}
\hline $\begin{array}{l}\text { INDICADORES DA EXISTÊNCIA } \\
\text { E GRAU DAS LIMITAÇÕES }\end{array}$ & $\begin{array}{l}\text { RAZÕES PELAS QUAL O INDICADOR } \\
\text { SIGNIFICA LIMITAÇÕES MAIORES }\end{array}$ \\
\hline Estrutura de recompensas. & $\begin{array}{l}\text { - Na medida em que as recompensas para alguns papéis são } \\
\text { altas, a expectativa é que os compradores sejam menos } \\
\text { flexíveis e menos interessados em permitir que outras } \\
\text { empresas na cadeia aprendam a desempenhar estes papéis. }\end{array}$ \\
\hline $\begin{array}{l}\text { Grau de interesse dos compradores no } \\
\text { aperfeiçoamento competitivo das empresas } \\
\text { estudadas, de maneira que vantagens de alto } \\
\text { nível como marcas, maior controle de canais } \\
\text { de distribuição e competências de design } \\
\text { possam ser obtidas. }\end{array}$ & $\begin{array}{l}\text { - Maior aperfeiçoamento competitivo significa que a empresa } \\
\text { conta com maiores possibilidades de obtenção de rendimentos } \\
\text { econômicos superiores. } \\
\text { - Pouco interesse dos compradores pode se dever à crença por } \\
\text { parte destes que há pouca possibilidade de se beneficiarem de } \\
\text { ganhos de produtividade na cadeia com o AC dos } \\
\text { fornecedores. } \\
\text { - Limitações maiores devido ao fato de que as empresas podem } \\
\text { até mesmo ser impedidas de ingressar em uma trajetória de } \\
\text { AC. }\end{array}$ \\
\hline $\begin{array}{l}\text { Grau de concentração no segmento } \\
\text { comprador. }\end{array}$ & $\begin{array}{l}\text { - Quanto maior a concentração no segmento comprador, a } \\
\text { expectativa é que as possibilidades de implementação de uma } \\
\text { estratégia sofisticada, que conduza aos rendimentos } \\
\text { econômicos superiores, sejam menores. }\end{array}$ \\
\hline Grau de sucesso de estratégias passadas. & $\begin{array}{l}\text { - Espera-se que quanto mais bem sucedidas as estratégias da } \\
\text { empresa no passado, maior seja a resistência à mudança. }\end{array}$ \\
\hline $\begin{array}{l}\text { Capacidade de redesenhar as rotinas da } \\
\text { empresa. }\end{array}$ & $\begin{array}{l}\text { - Há situações em que é difícil para a empresa redesenhar suas } \\
\text { atividades e rotinas, devido à existência de custos } \\
\text { irrecuperáveis (sunk costs), ativos específicos etc. }\end{array}$ \\
\hline
\end{tabular}

Finalmente, a verificação do nível de rendimento econômico que pode ser obtido pela empresa é realizada pelos indicadores que seguem no quadro 16: 


\section{Quadro 16 - Indicadores de possibilidade de obtenção de rendimentos econômicos superiores e respectivas razões}

\begin{tabular}{|c|c|}
\hline $\begin{array}{c}\text { INDICADORES DAS } \\
\text { POSSIBILIDADES DE } \\
\text { RENDIMENTOS ECONÔMICOS } \\
\text { SUPERIORES PELAS EMPRESAS }\end{array}$ & $\begin{array}{l}\text { RAZÕES DE O INDICADOR REPRESENTAR MAIORES } \\
\text { POSSIBILIDADES DE OBTENÇÃO DE RENDIMENTOS } \\
\text { ECONÔMICOS SUPERIORES }\end{array}$ \\
\hline $\begin{array}{l}\text { Movimentação para segmentos } \\
\text { econômicos mais rentáveis e/ou de maior } \\
\text { sofisticação tecnológica e/ou mais } \\
\text { intensivos em capital ou competências. }\end{array}$ & $\begin{array}{l}\text { - Para atuar nestes segmentos a empresa precisa desenvolver } \\
\text { capacitação superior. Não são muitas as empresas que logram } \\
\text { efetuar esta movimentação. Destarte, aquelas que conseguem, } \\
\text { enfrentam menor competição e, portanto, maiores possibilidades de } \\
\text { obtenção de rendimentos econômicos superiores. }\end{array}$ \\
\hline $\begin{array}{l}\text { Inovação continua nos itens que acima } \\
\text { (processo, produto ...) em comparação } \\
\text { aos concorrentes. }\end{array}$ & $\begin{array}{l}\text { - A ocorrência de inovação contínua pressupõe ações planejadas, } \\
\text { que só um número pequeno de empresas consegue desenvolver. }\end{array}$ \\
\hline $\begin{array}{l}\text { Aprendizado recente e possibilidade de } \\
\text { ocorrência no futuro próximo / distante. }\end{array}$ & $\begin{array}{l}\text { - Afere como está a capacitação corrente da empresa. Empresas que } \\
\text { aprendem continuamente têm maiores possibilidades de obtenção } \\
\text { de rendimentos econômicos superiores, pois aos concorrentes se } \\
\text { torna mais difícil igualá-las. }\end{array}$ \\
\hline $\begin{array}{l}\text { Utilização de fontes de aperfeiçoamento } \\
\text { na capacitação para alterar conhecimento. }\end{array}$ & $\begin{array}{l}\text { - As empresas para desenvolverem as chamadas capacitações } \\
\text { dinâmicas, devem estar aptas para alterar conhecimento. }\end{array}$ \\
\hline $\begin{array}{l}\text { Existência e importância da aquisição de } \\
\text { conhecimento tácito em tempos recentes. }\end{array}$ & $\begin{array}{l}\text { - A absorção de conhecimento tácito é de maior complexidade do } \\
\text { que a de conhecimento codificado. Portanto, é mais difícil de ser } \\
\text { copiado pelos concorrentes e isto pode trazer ganhos econômicos } \\
\text { maiores. }\end{array}$ \\
\hline $\begin{array}{l}\text { Grau de aperfeiçoamento competitivo de } \\
\text { processo, produto, funcional e inter- } \\
\text { setorial (foco nos três últimos). }\end{array}$ & $\begin{array}{l}\text { - Um produto de maior valor significa que a empresa desenvolveu } \\
\text { vantagens superiores. } \\
\text { - O deslocamento para outras funções na cadeia significa que a } \\
\text { empresa desenvolveu a capacidade de desempenhar funções } \\
\text { superiores, como por exemplo, marketing e design. } \\
\text { - Um deslocamento inter-setorial pode significar que a empresa } \\
\text { desenvolveu uma competência superior e aprendeu a aplicá-la em } \\
\text { um outro setor. }\end{array}$ \\
\hline $\begin{array}{l}\text { Alterações organizacionais e nas rotinas } \\
\text { em tempos recentes. }\end{array}$ & $\begin{array}{l}\text { - Verifica a flexibilidade da empresa. Empresas com mais } \\
\text { flexibilidade têm maior capacidade de adaptação e, portanto, mais } \\
\text { possibilidade de obtenção de rendimentos econômicos superiores. }\end{array}$ \\
\hline $\begin{array}{l}\text { Melhoramentos em itens valorizados } \\
\text { pelos compradores, como por exemplo, } \\
\text { qualidade e pontualidade. }\end{array}$ & $\begin{array}{l}\text { - Estas são vantagens superiores. Superiores à dependência de } \\
\text { preços baixos para atrair e manter compradores. Necessidade de } \\
\text { manutenção de preços baixos para atrair e manter compradores } \\
\text { contribui para rendimentos econômicos menores. }\end{array}$ \\
\hline
\end{tabular}

Também podem ser obtidas indicações das possibilidades de rendimentos econômicos maiores através da verificação indireta. Neste caso, é examinada a existência de inibidores e impulsionadores à ocorrência de aperfeiçoamento competitivo. 


\section{4 - Operacionalização das relações apresentadas na hipótese}

As empresas serão classificadas de acordo com os parâmetros apresentados para as variáveis independente, dependente e quanto às possibilidades de obtenção de maiores rendimentos econômicos que foram verificadas, conforme o esquema que segue na ilustração 13.

\section{Ilustração 13 - Esquema para classificação das empresas estudadas (operacionalização) \\ LIMITAÇÕES AO RE \\ (1) Maiores \\ PROATIVIDADE / SOFISTICAÇÃO \\ DAS ESTRATÉGIAS \\ (A) Maior pro atividade / sofisticação \\ RE \\ (ALFA) Maior}

- Recompensas altas p/

papéis / atividades

desempenhados por

compradores.

- Pouco interesse dos compradores

no AC dos fornecedores.

- Concentração alta no segmento

comprador.

\section{(2) Menores}

- Recompensas baixas p/

papéis / atividades

desempenhados por

compradores.

- Muito interesse dos compradores no AC dos fornecedores.

- Concentração baixa no segmento comprador.
Este esquema permite classificar as empresas estudadas nas seguintes categorias (QUADRO 17): 
Quadro 17 - Esquema proposto para a classificação das empresas estudadas

\begin{tabular}{|c|c|}
\hline CATEGORIA & DESCRIÇÃO \\
\hline $\begin{array}{l}\mathbf{1}-\mathbf{( 1 )}(\mathbf{A})(\mathbf{A L F A}) \\
\text { (maiores, maior, maiores) }\end{array}$ & 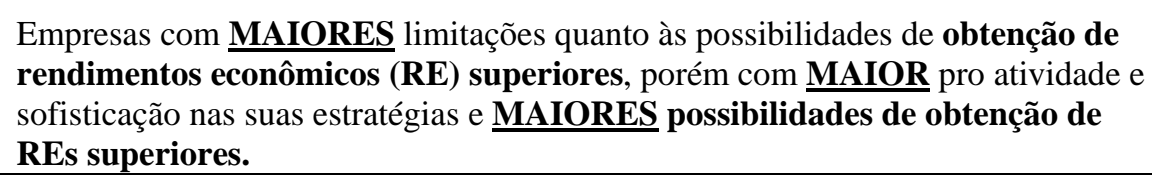 \\
\hline $\begin{array}{l}2-\quad(\mathbf{1})(\mathbf{A})(\mathbf{K}) \\
\text { (maiores, maior, menores) }\end{array}$ & 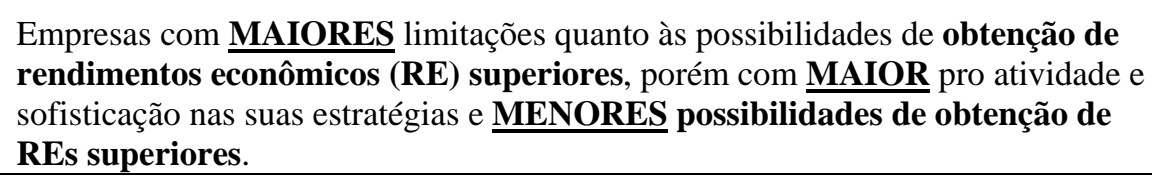 \\
\hline $\begin{array}{l}3 \text { - (1)(B)(ALFA) } \\
\text { (maiores, menor maiores) }\end{array}$ & $\begin{array}{l}\text { Empresas com MAIORES limitações à obtenção de REs superiores, MENOR } \\
\text { pro atividade e sofisticação nas suas estratégias, mas com } \underline{\text { MAIORES }} \\
\text { possibilidades de obtenção de REs superiores. }\end{array}$ \\
\hline $\begin{array}{l}4-\quad(\mathbf{1})(\mathbf{B})(\mathbf{K}) \\
\text { (maiores, menor, menores) }\end{array}$ & 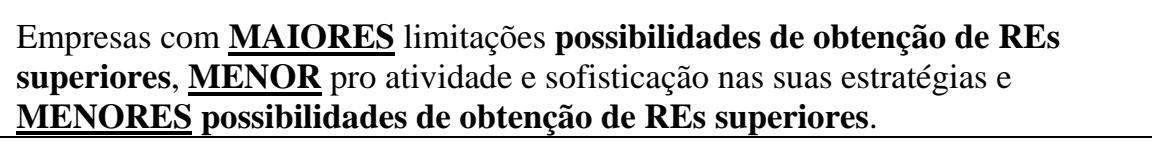 \\
\hline $\begin{array}{l}5-(2)(A)(A L F A) \\
\text { (menores, maior, maiores) }\end{array}$ & $\begin{array}{l}\text { Empresas com MENORES limitações às possibilidades de obtenção de REs } \\
\text { superiores, MAIOR pro atividade e sofisticação nas suas estratégias e } \\
\text { MAIORES possibilidades de obtenção de REs superiores. }\end{array}$ \\
\hline $\begin{array}{l}6 \text { - } \quad(2)(\mathbf{A})(\mathbf{K}) \\
\text { (menores, maior, menores) }\end{array}$ & $\begin{array}{l}\text { Empresas com MENORES limitações às possibilidades de obtenção de REs } \\
\text { superiores, MAIOR pro atividade e sofisticação nas suas estratégias, mas } \\
\text { mesmo assim apresentam MENORES possibilidades de obtenção de REs } \\
\text { superiores. }\end{array}$ \\
\hline $\begin{array}{l}7 \text { - (2)(B)(ALFA) } \\
\text { (menores, menor, maiores) }\end{array}$ & 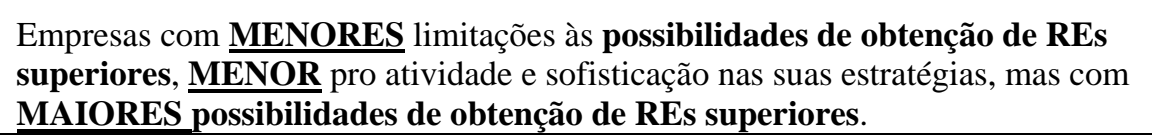 \\
\hline $\begin{array}{l}8 \text { - (2)(B)(K) } \\
\text { (menores, menor, menores) }\end{array}$ & $\begin{array}{l}\text { Empresas com MENORES limitações às possibilidades de obtenção de REs } \\
\text { superiores, MENOR pro atividade e sofisticação nas suas estratégias e } \\
\text { MENORES possibilidades de obtenção de REs superiores. }\end{array}$ \\
\hline
\end{tabular}

Em seguida a sua classificação nestas oito categorias, as empresas são analisadas de forma individual e comparadas. 


\section{Capítulo 5 - ANÁLISE DOS RESULTADOS}

\section{1 - Discussão}

Com a utilização dos conceitos de Kaplinsky e Morris (2003, p. 4-6) sobre cadeia de valor, segue a apresentação dos casos estudados quanto aos seus produtos (QUADRO 18).

\section{Quadro 18 - Casos estudados - apresentação comparativa quanto a produtos}

\section{\begin{tabular}{l|l} 
CASO & PRODUTO
\end{tabular}}

A1 Desenvolvimento e comercialização de soluções integradas de softwares de gestão empresarial para organizações de médio e grande porte.

A2 Desenvolvimento e comercialização de softwares de gestão empresarial integrada e serviços relacionados para o segmento composto pelas organizações de médio e pequeno porte no Brasil e na América Latina.

A3 Soluções completas em automação comercial (equipamentos, softwares e serviços relacionados) para o varejo de pequeno e médio porte.

B1 Integração de sistemas nos setores de telecomunicações e TI (planejamento, concepção, implantação, operação e manutenção de infra-estrutura).

B2 Terceirização de atividades de TI, como outsourcing, consultoria, desenvolvimento e integração de sistemas e $B P O$.

B3 Soluções integradas de TI (infra-estrutura e integração de sistemas) e BPO (central de atendimento e soluções para processos de negócios).

C1 Soluções, projetos, fábrica de software e consultoria para o setor financeiro.

C2 Soluções integradas de software e serviços para o gerenciamento eletrônico de documentos (GED).

FONTE: O AUTOR, 2008, com informações coletadas na pesquisa de campo e também em fontes secundárias.

Dentre as empresas estudadas, três não desenvolvem seus produtos internamente: A1, A3 e C1. Embora, as empresas A3 e C1 contem também com desenvolvimento interno. Em todas as empresas, com exceção da A3, que produz também equipamentos, nas demais o produto da atividade é serviço e conhecimento. Mesmo na A3, predomina o conhecimento sobre o aspecto tangível do produto. Em função destas características, o principal insumo do processo produtivo é mão-de-obra. Com relação ao marketing, o quadro 19, exibido na seqüência, traz o que foi revelado na pesquisa de campo. 
Quadro 19 - Papel do marketing e da construção de marcas

\begin{tabular}{|c|c|}
\hline CASO & $\begin{array}{l}\text { INFORMAÇÕES OBTIDAS QUANTO AO PAPEL DO MARKETING E DA CONSTRUÇÃO } \\
\text { DE MARCAS }\end{array}$ \\
\hline A1 & $\begin{array}{l}\text { Papel importante, pois há o marketing de produtos, que supervisiona os lançamentos. Também há o } \\
\text { marketing de comunicação, embora o mais importante sejam as indicações. }\end{array}$ \\
\hline A2 & Marca classificada como importante. Menção à reputação da empresa junto aos compradores. \\
\hline A3 & $\begin{array}{l}\text { Marca classificada como importante. Mencionadas as vantagens de possuir uma marca forte. Nos } \\
\text { EUA, o processo de construção da marca e demais atividades de marketing é de reconhecida } \\
\text { importância. Ponto forte n atuação é a qualidade e a intensidade dos canais de distribuição. }\end{array}$ \\
\hline B1 & $\begin{array}{l}\text { Foi notada a existência de atividades sofisticadas, como, por exemplo, inteligência de marketing e } \\
\text { desenvolvimento de produtos planejado com cuidado. }\end{array}$ \\
\hline B2 & Marca na prestação de serviços faz diferença. É importante que esteja associada à longevidade. \\
\hline B3 & $\begin{array}{l}\text { É reconhecida pela empresa a importância de estabelecer uma marca, inclusive no cenário } \\
\text { internacional. Tem investido em comunicação nos EUA, com os executivos das empresas } \\
\text { compradoras pertencentes ao segmento-alvo. }\end{array}$ \\
\hline C1 & $\begin{array}{l}\text { Atividade de marketing que funciona é a de relacionamento (com os compradores). Executivos } \\
\text { entrevistados avaliam que no segmento em que atuam há poucos casos de construção de marcas. }\end{array}$ \\
\hline C2 & $\begin{array}{l}\text { Marca classificada como importante pelo que traz junto consigo (confiabilidade, seriedade e } \\
\text { sofisticação tecnológica). }\end{array}$ \\
\hline
\end{tabular}

FONTE: O AUTOR, 2008, com informações coletadas na pesquisa de campo.

Embora nenhuma das empresas estudadas tenha atuação voltada para o mercado de consumo, seis das oito empresas classificaram este aspecto como importante. Houve menção a investimentos no exterior em construção de marca. Foram feitas várias menções à reputação e relacionamento com os compradores. Esta relevância para estes itens é esperada, visto a atuação das estudadas no segmento empresarial. Um outro aspecto relevante que surgiu foi o da longevidade e seriedade. Em um setor caracterizado pelo alto dinamismo e com baixas barreiras à entrada, a emergência destes aspectos pode ser considerada normal.

As redes, das quais participam algumas das empresas estudadas, tem como uma de suas características a flexibilidade, característica classificada como importante nos casos estudados. O quadro 20, exibido em seguida, traz alguns exemplos da flexibilidade que caracteriza a atuação das empresas objeto deste estudo. 


\section{Quadro 20 - Características do modelo de atuação e conseqüências quanto à}

\section{flexibilidade}

\begin{tabular}{|c|c|c|}
\hline EMPRESA & $\begin{array}{l}\text { CARACTERÍSTICAS DO } \\
\text { MODELO DE ATUAÇÃO }\end{array}$ & $\begin{array}{l}\text { CLASSIFICAÇÃO } \\
\text { COM RELAÇÃO À } \\
\text { FLEXIBILIDADE } \\
\text { COMO } \\
\text { CONSEQUÊNCIA } \\
\text { DO MODELO } \\
\text { ADOTADO } \\
\end{array}$ \\
\hline A1 & Opera com franquias de desenvolvimento e distribuição. & ALTA \\
\hline A2 & Atua de forma hierarquizada & BAIXA \\
\hline A3 & $\begin{array}{l}\text { Estrutura descentralizada no aspecto operacional. Parcerias no Brasil e } \\
\text { no exterior. Terceirização de atividades complexas, como } \\
\text { desenvolvimento de produtos. Mantém integradas atividades chave, } \\
\text { como, por exemplo, o projeto dos produtos. Desenvolvimento de } \\
\text { software para hispânicos integrado verticalmente. }\end{array}$ & ALTA \\
\hline B1 & $\begin{array}{l}\text { Atuação em rede. Articula grupo de fornecedores ao desenhar a } \\
\text { solução. Sensibilidade para diferenças culturais. }\end{array}$ & ALTA \\
\hline B2 & $\begin{array}{l}\text { Modelo parece privilegiar a disciplina sem transformá-la em obstáculo } \\
\text { à atuação saudável. }\end{array}$ & $\begin{array}{l}\text { DISCRETAMENTE } \\
\text { BAIXA }\end{array}$ \\
\hline B3 & $\begin{array}{l}\text { Baseado em planejamento antecipado das necessidades. Foco no } \\
\text { segmento-alvo (grandes empresas). Alto nível de integração. Revisão } \\
\text { permanente da estrutura organizacional para maior eficiência e } \\
\text { eficácia. }\end{array}$ & BAIXA \\
\hline C1 & $\begin{array}{l}\text { Organizada em unidades de negócios autônomas. Compete nos } \\
\text { mercados externos com parcerias. Modelo classificado de colaborativo. }\end{array}$ & $\begin{array}{l}\text { DISCRETAMENTE } \\
\text { ALTA }\end{array}$ \\
\hline C2 & $\begin{array}{l}\text { Integração vertical das atividades desenvolvidas. Flexibilidade é } \\
\text { atributo valorizado pelos executivos. }\end{array}$ & $\begin{array}{l}\text { DISCRETAMENTE } \\
\text { ALTA }\end{array}$ \\
\hline
\end{tabular}

FONTE: O AUTOR, 2008, com informações obtidas na pesquisa de campo.

Dentre as estudadas, a empresa que aparece como mais próxima da atuação em rede como descrevem Rugman e D’Cruz (2000, p. 70-72) é a empresa B1. Um fato que evidencia esta afirmação é a constante revisão de sua atuação quanto a produtos e parceiros. Contudo, embora neste caso a cadeia seja complexa, o custo de transação é diminuído pela existência de um ecossistema governado por uma grande empresa estadunidense de tecnologia. Também é possível que a estrutura rígida das empresas B2 e B3 seja conseqüência da padronização do produto foco da atividade. Esta padronização leva à competição centrada em preço. Uma forma de abaixar o custo de transação é a hierarquia vertical. Foi notado na organização B1 alto aprendizado. Com relação à capacidade de adaptação, há casos em que mesmo com a flexibilidade considerada baixa, há algum aspecto a mostrar no sentido contrário. A empresa 
B3, classificada como de baixa flexibilidade, tem adaptado sua estrutura organizacional com freqüência. A ponto dos executivos já terem se habituado a este estado de mudança permanente. A empresa B2, visto que é a que atua no maior número de países, certamente conta com flexibilidade para se adequar operacionalmente a um número variado de culturas e sistemas. A empresa C2 aponta como vantagem competitiva a flexibilidade em termos técnicos, pois diferente de suas concorrentes internacionais, conta com maior possibilidade de adaptação do produto.

Com relação à proteção de ativos valiosos nas estruturas não hierarquizadas, esta é uma preocupação da empresa B1. Contudo, o que parece ser o seu ativo mais valioso é a capacidade de encontrar novas formas de atuação, produtos, parceiros e mercados. O caso da empresa A1 também é interessante, pois o ativo mais valioso parece ser a capacidade de administrar este sistema de franquias, que conta com vários aspectos positivos. O caso da empresa A3 é semelhante, pois a organização parece não ter colocado em risco a capacidade de projeto, que é um dos ativos mais valiosos. Contudo, nestes três casos não se pode falar em contratação pelo mercado, mas sim em uma cadeia ou rede organizada.

Para utilizar os componentes das cadeias de valor indicados por Kaplinsky e Morris (2003, p. 25), o exame do quadro 21, que segue, auxilia na compreensão da parte que se apropria da renda nas cadeias das quais as empresas fazem parte. 
Quadro 21 - Renda econômica e governança nas cadeias em que as empresas estudadas estão conectadas

\begin{tabular}{|c|c|c|c|}
\hline EMPRESA & APROPRIAÇÃO DA RENDA & GOVERNANÇA? & QUEM GOVERNA? \\
\hline A1 & Empresa estudada & Sim & Empresa estudada \\
\hline A2 & Empresa estudada & Sim & Empresa estudada \\
\hline A3 & Empresa estudada & Sim & Empresa estudada \\
\hline B1 & $\begin{array}{c}\text { Líder da cadeia (empresa dos EUA) e } \\
\text { participantes da rede, o que inclui a } \\
\text { empresa estudada. }\end{array}$ & Sim & $\begin{array}{l}\text { Empresa originária dos } \\
\text { EUA, fabricante de } \\
\text { equipamentos. }\end{array}$ \\
\hline B2 & $\begin{array}{c}\text { Fornecedoras parceiras de tecnologia e } \\
\text { compradoras }\end{array}$ & Sim & Comprador \\
\hline B3 & $\begin{array}{l}\text { Fornecedoras parceiras de tecnologia e } \\
\text { compradoras }\end{array}$ & Sim & Comprador \\
\hline C1 & Empresa e compradoras & Sim & Comprador \\
\hline $\mathrm{C} 2$ & $\begin{array}{l}\text { Líder da cadeia, que é a empresa } \\
\text { fornecedora de equipamentos }\end{array}$ & Sim & $\begin{array}{l}\text { Fabricante de } \\
\text { equipamentos de origem } \\
\text { japonesa. }\end{array}$ \\
\hline
\end{tabular}

FONTE: Aplicação dos conceitos de KAPLINSKY; MORRIS, 2003, p. 25, pelo AUTOR às informações obtidas junto aos casos estudados, 2008.

A empresa A1 promoveu alterações na sua estrutura organizacional em 1999, de forma a estimular o espírito empreendedor dos desenvolvedores e canais, que foram transformados em franquias, no jargão utilizado pela empresa. Isto foi feito sem que a empresa deixasse de governar a cadeia e se apropriar da maior parte da renda gerada, que com a nova estrutura, de acordo com as declarações obtidas na pesquisa de campo, passou a ser maior. A empresa A2, em virtude de ter como foco o segmento composto pelas pequenas e médias empresas, provavelmente tem maior governança sobre sua cadeia do que a empresa A1, voltada para o segmento das PMEs. A razão é que a fragmentação no segmento da A2 é maior, em comparação com o segmento da A1, mais concentrado. No caso da empresa A3, sua capacidade de governar a cadeia também é forte. Além de dominar o projeto dos produtos hardware, oferece uma solução completa e o segmento comprador é fragmentado, pois é composto principalmente de pequenas e médias empresas. É possível que esta empresa já tenha alcançado um estágio superior, pois faz a gestão da cadeia a montante em países da Ásia e a jusante em países desenvolvidos. As empresas A1 e A2 fazem a gestão da cadeia a montante e a jusante em paises da América Latina e países de língua portuguesa. 
No caso da empresa B1, esta opera em uma cadeia liderada pela empresa dos EUA que organizou o ecossistema. Esta empresa parece ser a que aufere as maiores rendas, contudo também ocorre apropriação de parte importante da renda pela empresa estudada e pelas fornecedoras articuladas por ela, para estas últimas em menor escala. As empresas B2 e B3 estão em uma atividade que conta tem parceiros poderosos como fornecedores e estão voltadas para o segmento composto por grandes empresas e governo. As indicações são de que estas cadeias das quais estas duas empresas participam são governadas pelos compradores. A renda é provavelmente apropriada por estes e pelos parceiros fornecedores de tecnologia, poderosos na cadeia. As empresas B2 e B3 estão voltadas a segmentos de pouca fragmentação. A empresa B2 já se deu conta de que esta é uma fragilidade. No caso da B3, a concentração das vendas nos dez maiores clientes pode ser uma fragilidade, ainda mais consideradas as características da cadeia.

O caso da empresa C1, embora esta desenvolva e forneça soluções para missões críticas de empresas financeiras, o produto no qual houve foco o estudo - seguros - na atividade internacional as evidências são de que se trata de uma cadeia governada pelo comprador. $\mathrm{O}$ setor financeiro tem se tornado a cada dia menos fragmentado, isto é, a concentração tem aumentado. A organização estudada, como um movimento defensivo de perda de renda, também tem tratado de aumentar o seu porte. A empresa C2 atua em uma cadeia governada pelo fabricante de equipamentos, que é seu parceiro. Embora a empresa esteja aproveitando as conexões internacionais deste parceiro para evoluir na internacionalização, em virtude do desequilíbrio da relação em termos de porte e acesso a capital, para citar apenas alguns poucos aspectos, evidentemente traz fragilidades a este caso estudado.

Para abordar o assunto em linha com o que propõe Kogut (1985, p. 29), a empresa A1 opera com uma franquia de desenvolvimento de software na Argentina. A empresa A2 mantém desenvolvimento de software na Argentina e também no México e no Chile. A empresa A3 tem desenvolvimento de produtos em Taiwan, além de fabricação na China. Também conta com desenvolvimento de software na Argentina. A empresa B1 tem conexão com fornecedores em vários países. A empresa B2 mantém um centro de desenvolvimento de software no México e aproximadamente 500 funcionários trabalhando em operações fora do Brasil. A empresa B3 presta serviços para o exterior a partir do Brasil. As empresas C1 e C2 também operam somente a partir do Brasil. Todos os casos estudados realizam vendas ao exterior. O quadro 22, que segue, mostra um resumo destas informações. 
Quadro 22 - Atividades no exterior dos casos estudados

\begin{tabular}{|c|c|c|}
\hline EMPRESA & ATIVIDADES & PAÍSES \\
\hline A1 & $\begin{array}{l}\text { (1) Desenvolvimento de software } \\
\text { (2) Operação de vendas }\end{array}$ & $\begin{array}{l}\text { (1) Argentina } \\
\text { (2) Argentina, Chile, } \\
\text { Colômbia, México e Peru. }\end{array}$ \\
\hline A2 & $\begin{array}{l}\text { (1) Desenvolvimento de software } \\
\text { (2) Vendas }\end{array}$ & $\begin{array}{l}\text { (1) Argentina, México e } \\
\text { Chile. } \\
\text { (2) Argentina, Bolívia, } \\
\text { México, Paraguai e Porto } \\
\text { Rico. }\end{array}$ \\
\hline A3 & $\begin{array}{l}\text { (1) Desenvolvimento de produtos } \\
\begin{array}{l}\text { (2) Fabricação de equipamentos para o mercado dos EUA } \\
\text { (3) Desenvolvimento de software } \\
\text { (4) Vendas } \\
\text { (5) Acompanhamento de tendências da atividade de automação } \\
\text { comercial }\end{array}\end{array}$ & $\begin{array}{l}\text { (1) Taiwan } \\
\text { (2) China } \\
\text { (3) Argentina } \\
\text { (4) Todos os países da } \\
\text { América Latina, EUA e } \\
\text { países da América } \\
\text { Central. } \\
\text { (5) Alemanha e Taiwan }\end{array}$ \\
\hline B1 & $\begin{array}{l}\text { (1) Prestação de serviços a partir do Brasil (em fase de desativação) } \\
\text { (2) Conexão com fornecedores dependendo do projeto } \\
\text { (3) Vendas e operações a clientes (em implantação) }\end{array}$ & $\begin{array}{l}\text { (1) EUA } \\
\text { (2) Vários, principalmente } \\
\text { nos desenvolvidos. } \\
\text { (3) América Latina }\end{array}$ \\
\hline B2 & $\begin{array}{l}\text { (1) Desenvolvimento de software } \\
\text { (2) Operações a clientes } \\
\text { (3) Vendas }\end{array}$ & $\begin{array}{l}\text { (1) México } \\
\text { (2) (3) Alguns dos } 13 \\
\text { países que mantém } \\
\text { operações }\end{array}$ \\
\hline B3 & Prestação de serviços a clientes a partir do Brasil & $\begin{array}{l}\text { Canadá, EUA e países da } \\
\text { América Latina e da } \\
\text { Europa. }\end{array}$ \\
\hline C1 & Vendas & $\begin{array}{l}\text { Espanha, China, Filipinas, } \\
\text { Îndia, Indonésia e EUA } \\
\text { (início). }\end{array}$ \\
\hline $\mathrm{C} 2$ & Vendas & México e Portugal. \\
\hline
\end{tabular}

FONTE: O AUTOR, 2008, com informações obtidas na pesquisa de campo e em fontes secundárias.

Ainda com a abordagem de Kogut (1985, p. 29), quanto à natureza do envolvimento, o que se observa no quadro 22 é que, além da atividade de vendas, é freqüente o envolvimento com desenvolvimento, principalmente em países hispânicos da América Latina. De acordo com as informações obtidas nas entrevistas realizadas, estas empresas que realizam desenvolvimento na América Latina não estão à busca de custos mais baixos, mas principalmente de uma habilidade não disponível no Brasil, que é o domínio do idioma hispânico. No caso da empresa A3, que desenvolve produtos em Taiwan, esta busca competências não disponíveis 
no Brasil. A empresa A3, ao fabricar na China procura custos mais baixos para poder competir no mercado dos EUA. O caso B1, com seu envolvimento do tipo rede para articulação de fornecedores para projetos em outros países, pode ser considerada com ligações de alto nível no contexto internacional. As organizações B2 e B3 têm envolvimento internacional similar, embora a B2 com porte menor esteja mais avançada neste quesito. A mesma comparação se pode fazer entre as empresas C1 e C2, que possuem natureza similar de envolvimento internacional, com maior avanço da C1 nesta circunstância analisada.

As informações obtidas junto às empresas estudadas dão conta de que a tecnologia é um fator que pesa cada vez menos no negócio. Portanto, é possível falar em diferenças de custos devido às diferenças nos locais de produção. Há preocupação das empresas A3, B2 e B3. A empresa C2 também mencionou este aspecto. Há de se notar que as empresas B3 e C2 ainda pensam em obtenção de custos mais baixos somente dentro do país. As empresas A3 e B2 já abordam o tema em uma perspectiva global. A empresa A1 também menciona a vantagem de custo quando se refere a sua operação de desenvolvimento na Argentina, mas este aspecto não foi um determinante a priore da transferência da atividade para lá. De forma geral, o que se observou na atualidade na maior parte dos casos estudados é que há atenção das empresas entre este equilíbrio de capacitação e custo para transferência das atividades ao exterior. As empresas estudadas, mesmo as que estão menos avançadas neste aspecto - B3, C1 e C2 aparentemente não tem qualquer restrição a avaliar onde quebrar a cadeia de valor e para onde novos investimentos devem ser direcionados. A percepção é que as estudadas pensam a estratégia de forma integrada.

Em referência aos conceitos colocados por Sturgeon (2000, p. 6), a empresa B1 parece estar em uma rede, enquanto as demais parecem operar em cadeias. Possivelmente, a empresa A3 é a que opera as cadeias de forma mais sofisticada. Com os conceitos de Kaplinsky e Morris (2003, p. 9-13), pode-se afirmar que a empresa A3 está mais avançada nesta questão da competitividade sistêmica. Esta organização vai buscar atores para sua cadeia onde há o mais competitivo na atividade em termos globais. O caso B1 também se destaca neste quesito, pois a rede da qual faz parte atua em um nível global. O ecossistema desenvolvido pela líder dos EUA busca os melhores do mundo onde estiverem para aderirem a sua rede. 
Com as idéias de Gereffi et al (1994, p. 1) sobre os aspectos que seguem no quadro 23, em seguida, e também de Palpacuer (2000, p. 390) quanto à flexibilidade, é apresentada uma classificação das empresas quanto a cada um dos itens.

Quadro 23 - Características da operação em cadeias de valor das empresas estudadas

\begin{tabular}{|c|c|c|c|c|}
\hline EMPRESA & FLEXIBILIDADE & $\begin{array}{c}\text { DEDICAÇÃO } \\
\text { DOS RECURSOS }\end{array}$ & $\begin{array}{l}\text { DIFERENCIAÇÃO } \\
\text { DOS PRODUTOS }\end{array}$ & $\begin{array}{c}\text { LOTES } \\
\text { PEQUENOS }\end{array}$ \\
\hline A1 & Alta & $\begin{array}{l}\text { Discretamente } \\
\text { baixa }\end{array}$ & Discretamente baixa & $\begin{array}{c}\text { Direciona atuação } \\
\text { para compradores } \\
\text { de médio e grande } \\
\text { porte }\end{array}$ \\
\hline A2 & $\begin{array}{c}\text { Discretamente } \\
\text { baixa }\end{array}$ & Alta & Discretamente alta & Foco da atuação \\
\hline A3 & Discretamente alta & Alta & Discretamente baixa & Foco da atuação \\
\hline B1 & Muito alta & Baixa & Alta & $\begin{array}{c}\text { Capacitada para o } \\
\text { envolvimento em } \\
\text { projetos de grande } \\
\text { porte }\end{array}$ \\
\hline B2 & Discretamente alta & Discretamente alta & Discretamente baixa & $\begin{array}{c}\text { Direcionada para } \\
\text { atuação em clientes } \\
\text { e projetos de grande } \\
\text { porte }\end{array}$ \\
\hline B3 & Baixa & Discretamente alta & Baixa & $\begin{array}{c}\text { Direcionada para } \\
\text { atuação em clientes } \\
\text { e projetos de grande } \\
\text { porte }\end{array}$ \\
\hline C1 & Discretamente alta & Alta & Alta & $\begin{array}{c}\text { Modelo de atuação } \\
\text { para poucos } \\
\text { compradores de } \\
\text { cada vez, } \\
\text { independente do } \\
\text { porte. }\end{array}$ \\
\hline C2 & Discretamente alta & Alta & Alta & $\begin{array}{l}\text { Modelo de atuação } \\
\text { para poucos } \\
\text { compradores de } \\
\text { cada vez, } \\
\text { independente do } \\
\text { porte. }\end{array}$ \\
\hline
\end{tabular}

FONTE: O AUTOR, 2008, com conceitos de GEREFFI ET AL, 1994, p. 1 e PALPACUER, 2000, p. 390, aplicados aos casos estudados.

Gereffi et al (1994, p. 1) mencionam que as características da produção em cadeias de valor são especialização flexível, baixa dedicação de equipamentos, alta diferenciação de produtos e lotes pequenos. Na verdade, estas observações foram feitas para cadeias de produtos tangíveis - bens - enquanto que os produtos das empresas estudadas são, em sua maioria, serviços. A empresa A3 é a única que se pode afirmar envolvida com bens, embora tenha ampliado sua oferta em tempos recentes. Contudo, dentre os casos estudados, o que chega mais perto da 
definição de Gereffi et al (1994, p. 1) é a empresa B1, que é a oferta com maior nível de intangibilidade dentre todas as estudadas. Em seguida as empresas C1 e C2, com seu alto nível de diferenciação de produto e possibilidade de atender pedidos pequenos são as que se destacam com relação à aproximação dos conceitos apresentados. Com relação às idéias de Palpacuer (2000, p. 390) sobre flexibilidade, a que fica mais longe mais longe neste item é a empresa B2, pelo seu porte e pela oferta de produtos padronizada.

Quanto aos atores econômicos, noção colocada por Gereffi (1996, p. 437), em todos os casos foi observada ênfase na gestão de pessoas. Não é de se estranhar que isto ocorra, visto que este é o principal insumo de empresas de serviços, como são as estudadas. Outro aspecto digno de nota diz respeito aos financiadores, pois três das oito empresas estudadas têm capital aberto (A1, A2 e A3) e outras três consideram a possibilidade de seguir este caminho (B2, B3 e C1). Também deve ser notado que as empresas B3 e C1 possuem fundos de investimento entre seus acionistas. A presença de fundos de investimento também ocorre ou ocorreu em etapas anteriores nos casos que têm ações negociadas em bolsa. A questão de terceirização dos canais de distribuição e existência de parceiros na atuação internacional foi mencionada de forma explícita em todos os casos, exceto na B2.

Há casos em que se pode fazer referência aos conceitos de Albornoz e Yoguel (2004, p. 620), pois, como é o exemplo da A2 no qual a atividade de desenvolvimento é operada com integração vertical, também presente - de forma planejada - em 50\% da distribuição.

Em todos os casos se verifica a coordenação de atividades através de fronteiras, como raciocina Whitley (1996, p. 411, 414-416, 418 e 422) para definir o foco das GVCs. Também há referência à variabilidade quanto aos agentes dominantes e centralização dos sistemas de coordenação, como foi observado nos casos estudados. Contudo, exceto nos casos das empresas B2 e B3, onde parece claro que o custo do trabalho é um fator explanatório importante, nos demais casos isto não parece ocorrer. O fator explanatório da cadeia nos casos das empresas A1 e A2, onde pode ser caracterizada a cadeia para distribuição, é o custo de transação, que é diminuído pela proximidade do comprador. A cadeia na qual está envolvida a empresa C1 também pode ser explicada pela diminuição do custo de transação. Nos casos estudados também pode ser observada a inexistência de um grupo de empresas que domina em todos os casos. Isto pode ser explicado pelo maior pluralismo do setor de TI, que faz com 
que as formas de organização econômica sejam instáveis, ou pelo menos mais instáveis do que em outros setores menos suscetíveis a novos entrantes.

Com a estrutura proposta por Dolan e Humphrey (2000, p.148), é possível abordar as relações entre as estudadas e seus fornecedores e canais de distribuição com o conceito da GVC. O quadro 24, exibido em seguida, apresenta os responsáveis e onde são desenvolvidas as atividades em cada caso estudado. 
Quadro 24 - Distribuição das atividades em empresas e países nos casos estudados

\begin{tabular}{|c|c|c|c|}
\hline \multirow[b]{2}{*}{ EMPRESA } & \multicolumn{3}{|c|}{ ATIVIDADE } \\
\hline & DESENVOLVIMENTO & $\begin{array}{c}\text { PRODUÇÃO/ } \\
\text { IMPLEMENTAÇÃO }\end{array}$ & MARKETING \\
\hline A1 & $\begin{array}{l}\text { - Franquias no Brasil e no } \\
\text { exterior. }\end{array}$ & Franquias no Brasil e no exterior & $\begin{array}{l}\text { - Franquias de distribuição } \\
\text { no Brasil e no exterior. }\end{array}$ \\
\hline A2 & $\begin{array}{l}\text { - Integrado verticalmente } \\
\text { (IV) }\end{array}$ & $\begin{array}{l}\text { Implementação parte própria e } \\
\text { parte com terceiros }\end{array}$ & $\begin{array}{l}\text { - 50\% da distribuição é IV } \\
\text { e 50\% da distribuição é } \\
\text { realizada através de } \\
\text { franquias no Brasil e no } \\
\text { exterior. }\end{array}$ \\
\hline A3 & $\begin{array}{l}\text { - Taiwan para hardware } \\
\text { (terceirizado). } \\
\text { - Argentina para software } \\
\text { (IV). }\end{array}$ & $\begin{array}{l}\text { - Brasil (IV) e China } \\
\text { (terceirizado) para hardware. } \\
\text { - Terceiros para implementação } \\
\text { em software. }\end{array}$ & $\begin{array}{l}\text { - Distribuidores } \\
\text { terceirizados no exterior. }\end{array}$ \\
\hline B1 & - Terceirizado & - Terceirizado & $\begin{array}{l}\text { - Monta bases operacionais } \\
\text { locais nos países que são } \\
\text { responsáveis por esta } \\
\text { atividade (IV). }\end{array}$ \\
\hline B2 & - Terceirizado & - IV & $\begin{array}{l}\text { - Distribuição e } \\
\text { comunicação } \\
\text { desenvolvidas pela própria } \\
\text { empresa (IV). }\end{array}$ \\
\hline B3 & - IV & - IV & $\begin{array}{l}\text { - Contrato com parceiros } \\
\text { no exterior para } \\
\text { desenvolvimento de } \\
\text { mercado (Europa). } \\
\text { Atividade de comunicação } \\
\text { conduzida pela própria } \\
\text { empresa nos EUA a partir } \\
\text { do Brasil. }\end{array}$ \\
\hline C1 & $\begin{array}{l}\text { - Parte IV e parte terceirizado } \\
\text { (Índia). }\end{array}$ & $\begin{array}{c}\text { - IV no Brasil e terceirizado no } \\
\text { exterior }\end{array}$ & $\begin{array}{l}\text { - IV no Brasil e sem } \\
\text { atividade no exterior }\end{array}$ \\
\hline $\mathrm{C} 2$ & - IV & $\begin{array}{c}\text { - IV no Brasil e terceirizado no } \\
\text { exterior }\end{array}$ & $\begin{array}{l}\text { - IV no Brasil e sem } \\
\text { atividade no exterior }\end{array}$ \\
\hline
\end{tabular}

Legenda. IV: Integração vertical.

FONTE: AUTOR, 2008, com conceitos de DOLAN; HUMPHREY (2000, p.148), aplicados aos casos estudados.

Cabe notar que todos os casos estudados possuem algum nível de terceirização. Somente a empresa A1 não conta com integração vertical em nenhum aspecto do negócio. Seu modelo de negócio é totalmente baseado em relações com empresas terceirizadas. A implementação nas empresas de software com freqüência é incluída no contrato de distribuição. 
Possivelmente a empresa que conta com o maior grau de integração vertical é a empresa B2. As empresas B2 e B3 têm parte importante de sua atividade ligada ao outsourcing de atividades de seus clientes, normalmente grades empresas. Portanto, não faz muito sentido pensar em terceirização nestes casos. No entanto, a empresa B3 contratou com um parceiro a atividade de desenvolvimento de mercado na Europa. Pelas informações obtidas junto à empresa B2, todos os produtos são de terceiros. A empresa não tem nenhum produto próprio. No caso da empresa B3, há fábrica de software. Foi incluído o que ocorre no Brasil nos casos estudados para uma melhor contextualização das informações. Algumas vezes as empresas atuam no Brasil para compradores no exterior. É o caso da empresa B3. O grau de utilização de terceiros, em muitos dos casos, é maior nas atividades no exterior do que no Brasil.

Com relação às idéias apresentadas por Kaplinsky (2005, p. 112-113) quanto à conexão aos mercados finais, embora existam diferenças entre produtores de bens e de serviços, como são as empresas estudadas, é possível, com adaptações, usar os conceitos. Primeiro, embora todas as empresas coloquem ênfase no fator escala para a competitividade, as empresas A2, A3, B2 e B3 não podem ser consideradas produtores de baixa escala. Também, não se pode falar na utilização de comprador ou agente de exportação dentro do Brasil. As empresas B3 e C1 mencionaram contatos no Brasil para exportação, mas não são empresas especializadas nesta atividade. Os contatos nestes dois casos são feitos com as empresas compradoras no Brasil, que levam o produto para outras filiais. Também aconteceu em parte na empresa A1. Depois, não se pode falar na utilização de varejistas no exterior. Portanto, a ilustração 14, apresentada em seguida, traz como os casos estudados se conectam aos mercados no exterior. 
Ilustração 14 - Como os as empresas estudadas se conectam aos mercados finais (exterior)

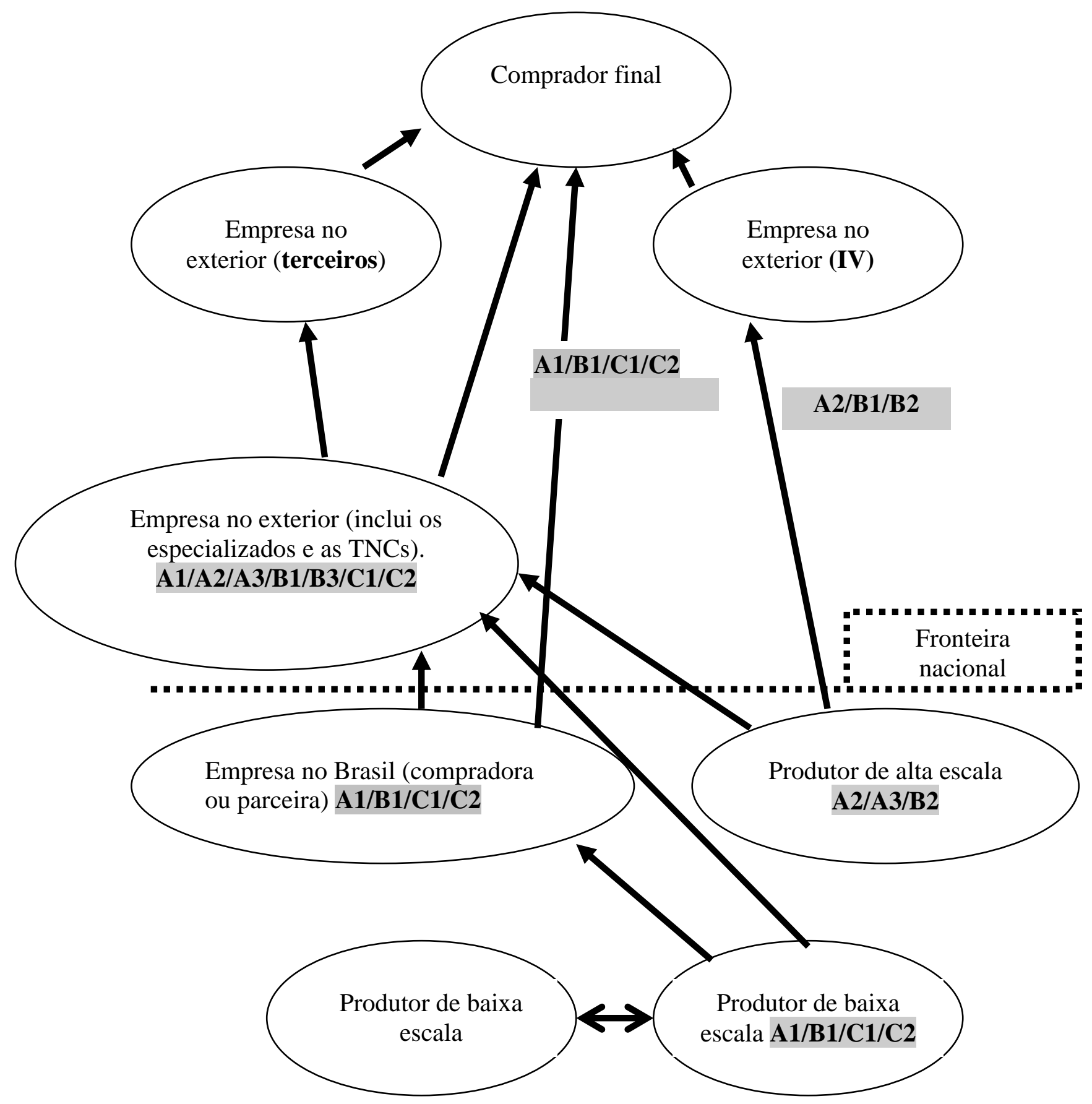

Legenda.

- TNC: Empresa transnacional.

- IV: Integração vertical.

FONTE: AUTOR, 2008, com conceitos de KAPLINSKY (2005, p. 112) e informações sobre os casos estudados coletadas na pesquisa de campo.

Com exceção das empresas A2, B1 e B2, que utilizam pelo menos parcialmente, filiais próprias no exterior, as demais se relacionam com terceiros. 
Exceto nas operações das empresas B2 e B3, não se pode falar em mão-de-obra de baixo custo. Contudo, também podem ser encontradas empresas independentes especializadas. São especializadas na distribuição, nos casos das empresas A1 e A2. Na empresa A3 também se pode falar em empresa especializada em desenvolvimento na distribuição. A empresa A3 utiliza empresa especializada em desenvolvimento de produto (Taiwan) e em fabricação (China). Há empresas de distribuição envolvidas também neste caso, além dos parceiros para implementação de software. Na empresa B1 há a utilização de parceiros fornecedores no exterior. A empresa B3 lançou mão de uma empresa especializada para auxiliá-la na estratégia de desenvolvimento de mercado. Contudo, diferente do que indica Kaplinsky (2005, p. 112) para setores como confecções, brinquedos, calçados, alimentos processados e móveis, não foram identificadas organizações que atuam como OEMs. Pode-se falar em envolvimento na chamada produção triangular no caso da A3. Neste caso, a empresa desenvolve o típico papel de empresa de país de renda média. Com relação a este último ponto, contudo, foi identificado que a empresa A3 está envolvida na produção triangular quando produz na China para comercializar nos EUA, um país de alta renda. Aliás, este papel converge com as características do Brasil, considerado por alguns organismos internacionais como país de renda intermediária (BANCO MUNDIAL, 2008, p. 78). Também se pode falar em produção triangular nos casos das empresas A1, A2, B1 e C1, pois ocorre a triangulação, mas nem sempre para consumo nos países desenvolvidos. No caso da empresa C1, esta trabalha com empresa terceirizada na Índia há seis ou sete anos, mas o produto é utilizado principalmente nos países em desenvolvimento, com duas exceções (Brasil, Índia, China, Indonésia, Filipinas, Espanha e EUA).

Com relação à definição relacionada à cadeia ser global ou não, de acordo com a definição de Sturgeon (2000, p. 8), pode ser afirmado que as empresas estudadas integram suas atividades em parte no exterior. Contudo nem sempre é em uma região da chamada tríade (composta por EUA, Europa e Japão). As empresas A3, B1, B2, B3, C1 e C2 integram alguma atividade em região da tríade. Os casos A1 e A2 estão focados na expansão na América Latina. O exame do quadro 22 facilita a compreensão desta situação.

Ainda de acordo com a definição de Sturgeon (2000, p. 10), dentre as estudadas não há empresa integrada. Aliás, de acordo com o depoimento das empresas entrevistadas, parece pouco comum, se é que existe, alguma empresa completamente integrada em TI. 
O quadro 25, exibido a seguir, esclarece os papéis desempenhados pelos atores nas cadeias das quais participam as empresas estudadas.

Quadro 25 - Identificação dos atores nas cadeias dos casos estudados

\begin{tabular}{|c|c|c|c|c|}
\hline CASO & LÍDER & $\begin{array}{l}\text { FORNECEDOR } \\
\text { TURN-KEY }\end{array}$ & $\begin{array}{c}\text { COMERCIALIZAÇÃO } \\
\text { (1) }\end{array}$ & $\begin{array}{c}\text { FORNECEDOR DE } \\
\text { COMPONENTES }\end{array}$ \\
\hline A1 & $\begin{array}{l}\text { - Empresa estudada } \\
\text { pode ser considerada líder } \\
\text { da cadeia, pois governa as } \\
\text { relações com as franquias } \\
\text { de desenvolvimento e } \\
\text { distribuição. }\end{array}$ & - Não aplicável & $\begin{array}{l}\text { - Desempenhadas pelas } \\
\text { empresas terceirizadas, } \\
\text { governadas pela estudada. }\end{array}$ & $\begin{array}{l}\text { - Fornecedores de } \\
\text { equipamentos da } \\
\text { estudada. }\end{array}$ \\
\hline A2 & $\begin{array}{l}\text { - Empresa estudada } \\
\text { pode ser considerada líder } \\
\text { da cadeia, embora a } \\
\text { atividade de vendas e } \\
\text { distribuição só conte com } \\
50 \% \text { de integração } \\
\text { vertical. }\end{array}$ & - Não aplicável & $\begin{array}{l}\text { - Desempenhada em parte } \\
\text { pelas empresas } \\
\text { terceirizadas, governadas } \\
\text { pela estudada. }\end{array}$ & $\begin{array}{l}\text { - Fornecedores de } \\
\text { equipamentos da } \\
\text { estudada. }\end{array}$ \\
\hline A3 & $\begin{array}{l}\text { - Empresa estudada } \\
\text { pode ser considerada líder } \\
\text { da cadeia, pois governa a } \\
\text { relação de } \\
\text { desenvolvimento de } \\
\text { produto e com as } \\
\text { empresas de distribuição.. }\end{array}$ & - Não aplicável & $\begin{array}{l}\text { - Empresa utiliza } \\
\text { distribuidores nos países } \\
\text { em que atua. }\end{array}$ & $\begin{array}{l}\text { - Fabricantes na } \\
\text { China (baixo nível). } \\
\text { - Desenvolvedores de } \\
\text { produto em Taiwan } \\
\text { (fornecedor } \\
\text { especializado). }\end{array}$ \\
\hline B1 & $\begin{array}{l}\text { - Empresa dos EUA que } \\
\text { organizou o ecossistema. }\end{array}$ & $\begin{array}{l}\text { - Empresa } \\
\text { estudada. }\end{array}$ & $\begin{array}{l}\text { - Papel e } \\
\text { desempenhado pela } \\
\text { empresa estudada, que } \\
\text { pode ser considerada um } \\
\text { revendedor de valor } \\
\text { adicionado (VAR). }\end{array}$ & \\
\hline B2 & $\begin{array}{l}\text { - Cadeia liderada pelos } \\
\text { compradores com } \\
\text { fornecedores poderosos }\end{array}$ & $\begin{array}{l}\text { - Papel em algumas } \\
\text { situações } \\
\text { desempenhado pela } \\
\text { empresa } \\
\text { estudada. }\end{array}$ & $\begin{array}{l}\text { - Papel em algumas } \\
\text { situações desempenhado } \\
\text { pela empresa estudada. }\end{array}$ & $\begin{array}{l}\text { - Papel em grande } \\
\text { parte desempenhado } \\
\text { pela empresa } \\
\text { estudada, cujo } \\
\text { produto em muitas } \\
\text { situações conta com } \\
\text { pouca diferenciação. }\end{array}$ \\
\hline B3 & $\begin{array}{l}\text { - Cadeia liderada pelos } \\
\text { compradores com } \\
\text { fornecedores poderosos }\end{array}$ & $\begin{array}{l}\text { - Papel em algumas } \\
\text { situações } \\
\text { desempenhado pela } \\
\text { empresa } \\
\text { estudada. }\end{array}$ & $\begin{array}{l}\text { - Papel em algumas } \\
\text { situações desempenhado } \\
\text { pela empresa estudada. }\end{array}$ & $\begin{array}{l}\text { - Papel em grande } \\
\text { parte desempenhado } \\
\text { pela empresa } \\
\text { estudada, cujo } \\
\text { produto em muitas } \\
\text { situações conta com } \\
\text { pouca diferenciação. }\end{array}$ \\
\hline C1 & $\begin{array}{l}\text { - Cadeia liderada pelo } \\
\text { comprador. }\end{array}$ & $\begin{array}{l}\text { - Papel } \\
\text { desempenhado pela } \\
\text { empresa estudada }\end{array}$ & $\begin{array}{l}\text { - Papel desempenhado em } \\
\text { grande parte pela } \\
\text { empresa estudada. }\end{array}$ & $\begin{array}{l}\text { - Papel } \\
\text { desempenhado pelas } \\
\text { contratadas da } \\
\text { estudada no exterior. }\end{array}$ \\
\hline C2 & $\begin{array}{l}\text { - Cadeia liderada pelo } \\
\text { fornecedor de } \\
\text { equipamentos (país } \\
\text { desenvolvido). }\end{array}$ & $\begin{array}{l}\text { - Papel } \\
\text { desempenhado pela } \\
\text { empresa } \\
\text { estudada. }\end{array}$ & $\begin{array}{l}\text { - Papel desempenhado } \\
\text { pela empresa estudada. }\end{array}$ & $\begin{array}{l}\text { - Papel } \\
\text { desempenhado pelas } \\
\text { contratadas da } \\
\text { estudada no exterior. }\end{array}$ \\
\hline
\end{tabular}


(1): O termo original é varejista, contudo foi alterado, pois não faria sentido nos casos estudados.

FONTE: AUTOR, 2008, com conceitos de STURGEON, 2000, p. 10 aplicados aos casos estudados. Informações coletadas na pesquisa de campo.

Embora na maior parte das situações seja possível avaliar com clareza o papel da empresa estudada, há situações em que o papel da empresa estudada pode ser classificado de duas formas. Conforme o quadro 25, esta situação ocorre nos casos B1, B2, B3, C1 e C2. No caso da empresa B1, o principal papel é fornecedor turn-key dos compradores. Contudo, este caso estudado pode ser considerado um revendedor de valor adicionado (VAR). Nos casos B2 e B3, as empresas têm várias ofertas diferentes e cada uma delas pode ser classificada de forma diferente. Já os casos das empresas C1 e C2, estas podem ser consideradas fornecedoras turnkey dos compradores. Contudo, também desempenham papel de comercializadoras das suas soluções.

Com os conceitos de Schmitz e Knorringa (1999, p. 6) e também de Kaplinsky (2000, p. 128), em conjunto com a observação do quadro 29 é possível inferir que as empresas B2 e B3 desempenham atividade que propicia rendas baixas. Contudo, principalmente no caso da B3, ficou evidente que os entrevistados percebem isto e desempenham esta atividade para poder migrar para aquelas que trazem maiores rendas e também para bloquear concorrentes que poderão ambicionar a mesma trajetória. De acordo com as informações obtidas, a empresa B2 tem migrado, por força dos alegados constrangimentos que o ambiente brasileiro impõe, para serviços mais sofisticados, nos quais o peso do fator mão-de-obra é menor. No entanto, a principal tática para neutralizar os fatores impulsionadores em direção às baixas rendas é a busca de escala. A empresa B3 também tem procedido nesta direção.

Com observações de Humphrey (2003, p. 10) sobre a contribuição da abordagem GVC, a coordenação através de uma rede de empresas aparece mais claramente no caso da empresa B1. Nas empresas A1 e A3, além de se poder mencionar o termo rede de empresas e coordenação, esta última atividade é desempenhada pela empresa brasileira estudada. Um fato reconhecido por várias das empresas estudadas e que também vai ao encontro dos argumentos de Humphrey (2003, p. 10) é o papel cada vez menos importante da tecnologia na formação dos sistemas de produção e distribuição globalmente dispersos. Aqui se faz uma analogia com a menção ao papel desempenhado pelas empresas não manufatureiras nos setores 
considerados como tradicionais como os de produtos alimentícios, confecções, brinquedos, móveis etc.

Com relação à constatação de Humphrey e Schmitz (2002, p. 3) de que o acesso aos mercados dos países desenvolvidos é cada dia mais dependente da entrada nas redes de produção das empresas líderes, foi verificado o seguinte nos casos estudados:

- $\quad$ As empresas A1, A2 e A3 são as líderes de suas cadeias, mas não se pode falar em acesso aos mercados dos países desenvolvidos, pois nos três casos há foco na ampliação da atuação no mercado dos países latino-americanos. A única exceção é a empresa A3, que atua no mercado dos EUA como líder da cadeia.

- $\quad$ No caso da empresa B1, a líder da cadeia é uma empresa dos EUA. Aqui também há foco no mercado latino-americano.

- $\quad$ No caso da empresa B2, seu modo de atuar não depende de uma empresa para intermediar o acesso aos mercados dos países desenvolvidos. Neste caso, o contato é feito diretamente, mas se examina o peso que o Brasil tem na operação da compradora. A cadeia é dominada pela compradora, com fornecedores poderosos. É possível que alguns destes fornecedores apóiem a estudada no acesso aos mercados desenvolvidos, mas este caminho parece ter peso menor do que o acesso direto.

- $\quad$ A empresa B3 está em contato com uma empresa da Europa que pode lhe facilitar o acesso aos compradores daquele país. No mercado dos EUA, a percepção é que embora a empresa tenha desenvolvido algumas ações de comunicação naquele país, ainda não há clareza como se pode acessar o mercado.

- $\quad$ A empresa $\mathbf{C 1}$ acessou os mercados dos países desenvolvidos a partir de empresas que atuam no Brasil e que compram seus produtos. É uma cadeia governada pelos compradores, que determinam inclusive quem vai prestar serviços de implementação dos sistemas no nível local, embora estes sejam contratados pela estudada.

- $\quad$ A empresa C2 vai para os países desenvolvidos com o estímulo e o apoio da líder da cadeia, que é a fabricante de equipamentos. Este caso confirma a constatação de Humphrey e Schmitz (2002, p. 3).

Dentre as estudadas, há a confirmação de que atividades da cadeia de valor podem ser organizadas com eficácia sem a necessidade de possuí-la no caso A1 (STEINFELD, 2002, p. 6-7). O que os executivos da organização A1 chamam de corporação conta com somente 150 
funcionários, frente aos mais de três mil que compõe a cadeia da empresa. Não resta dúvida que a influência da corporação é forte. Também no caso A2 houve a opção de se terceirizar parcialmente a atividade de distribuição, como um reconhecimento de que alguma competição entre a estrutura verticalmente integrada e as empresas contratadas seria positiva para a organização. O caso A3 também confirma esta noção, pois são terceirizadas atividades de desenvolvimento de produto, fabricação e distribuição. A estudada exerce influência através da manutenção do projeto integrado verticalmente. A empresa B1 se especializou, segundo as palavras do dirigente entrevistado, ocorreu a especialização no desenho de soluções e seleção e coordenação dos fornecedores. Possivelmente as empresas B2 e B3 são as mais integradas das que compõem a amostra e isto se deve ao fato delas próprias serem as terceirizadas. Estes dois casos estudados também parecem ser os que mais competem em preço. A organização B3 parece ter um plano tático mais estruturado sobre como migrar para as atividades que oferecem renda maior. As empresas C1 e C2 atuam através de parceiros no exterior.

Com relação à crescente preferência de utilização dos mesmos fornecedores em diferentes locais, isto foi verificado no caso da empresa A1, que tem prestado serviços a empresas multinacionais, que atuam no Brasil, quando estas estão instaladas em outros países latinoamericanos. No caso da empresa B2, embora preste serviços no exterior para multinacionais instaladas no Brasil, esta questão da preferência, de acordo com as respostas obtidas pareceu não ter peso. A empresa C1 é um caso bem típico neste sentido, embora tenha sido informado que em cada novo país foi necessário efetuar uma nova venda. Houve países que a subsidiária da multinacional optou por não comprar as soluções da estudada. Segundo os entrevistados, pesou na decisão o porte da estudada, à época muito pequeno, o que causou insegurança na compradora.

Quanto às oportunidades para fornecedores do segundo nível, a avaliação é que as estudadas estão se posicionando como fornecedoras do primeiro nível. No tocante às oportunidades para outras empresas de origem brasileira, os resultados do trabalho de campo indicam que as estudadas avaliam empresas de todas as origens em uma base pragmática, isto que sem direcionamento para organizações da mesma origem.

Quanto à evolução das ligações contratuais entre empresas independentes, o quadro 26, que segue apresenta um resumo, com base nas afirmações de Gibbon e Ponte (2005, p. 78). 
Quadro 26 - Forma de evolução das ligações das empresas estudadas no exterior

\begin{tabular}{|c|l|l|}
\hline EMPRESA & \multicolumn{1}{|c|}{ LIGAÇÃo } & \multicolumn{1}{|c|}{ FORMA DE EVOLUÇÃo } \\
\hline A1 & $\begin{array}{l}\text { - Desenvolvimento de software } \\
\text { - Distribuição }\end{array}$ & - Integração vertical \\
\hline A2 & - Distribuição & $\begin{array}{l}\text { - Integração vertical (ainda ocorre } \\
\text { em 50\% dos canais) }\end{array}$ \\
\hline A3 & $\begin{array}{l}\text { (1) Desenvolvimento de produtos } \\
\text { (2) Fabricação de equipamentos para o mercado dos EUA }\end{array}$ & $\begin{array}{l}\text { - Integração vertical nas três } \\
\text { situaços. }\end{array}$ \\
\hline B1 & - Soluções & - Mercado \\
\hline B2 & - Não tem ligação, pois funciona com hierarquia. & - Não se aplica \\
\hline B3 & - Desenvolvimento de estratégia de atuação na Europa & - Integração vertical \\
\hline C1 & - Implantação da solução & - Integração vertical \\
\hline C2 & - Vendas e implantação da solução & - Integração vertical \\
\hline
\end{tabular}

FONTE: AUTOR, 2008, com os conceitos de GIBBON; PONTE, 2005, p. 78 aplicados aos casos estudados.

Como se pode verificar pela observação do quadro 26, em grande parte dos casos estudados, a evolução ocorreu a partir da integração vertical das atividades. Somente no caso da empresa B1 é que as ligações com as empresas nos projetos desenvolvidos no exterior ocorreram a partir do mercado. Nos demais casos estas atividades estavam integradas verticalmente. Em alguns casos, na atuação nacional a atividade ainda se encontra integrada verticalmente. Este evidentemente não é o caso da organização A1, que contrata fora todas as atividades de desenvolvimento e distribuição. No caso da empresa A2 também há coincidência na atuação local e na atuação externa, pois no Brasil também é seguido este modelo de ter 50\% da distribuição própria e 50\% da distribuição terceirizada. Na empresa A3, o desenvolvimento de produtos foi terceirizado a nível global. A fabricação de produtos no Brasil não é totalmente integrada verticalmente. A empresa fabrica produtos fora e revende produtos de terceiros com sua marca (os fornecedores funcionam como OEMs). A distribuição no Brasil é feita através de revendas, mas a empresa conta com onze filiais próprias distribuídas pelo país. No caso da empresa B3, o que ocorre no país e em outras situações é que a estratégia de atuação é delineada internamente. No caso C1 e no caso C2, as atividades que são realizadas fora com terceiros contratados, no Brasil são desenvolvidas pelas próprias empresas. 
Com relação à atração pela mão-de-obra barata, primeiro foi unânime a afirmação de que mão-de-obra brasileira já não é tão mais barata assim. Mesmo se esta afirmação for contextualizada, o fato é que as empresas estudadas, mesmo se fosse o caso, acreditam que não poderiam depender desta vantagem. Segundo, as empresas que devido a sua atividade dependem do custo de mão-de-obra para competir são a B2 e a B3. As demais competem em outras bases.

De forma geral não se afirmou que os intermediários seriam um bloqueio ao desenvolvimento das empresas estudadas. Este fenômeno apareceu com alguma força no caso B1, mas a organização já entendeu que a relação com a empresa líder da cadeia é frágil e procura sempre se antecipar à próxima onda tecnológica para minimizar os efeitos de um rompimento, como já ocorreu em outra cadeia que participava. Mesmo neste caso, o papel desempenhado pela líder é positivo. No caso dos intermediários, as empresas pareceram ter controle das relações, se bem que estas empresas não atuam como intermediários no sentido do termo que foi empregado por Schmitz e Knorringa (1999, p. 3). Portanto, diferente do que nota Knutsen (2004, p. 545) nos casos estudados, o papel dos compradores não é desfavorável, embora nem todas as cadeias sejam dominadas por estes.

Com relação à forma de organização, dos casos estudados, as empresas A1, A3 e B1 são aquelas que mais se aproximam da descrição de Humphrey e Schmitz (2000, p. 10), pois: - $\quad$ A empresa A1 realiza todas as suas atividades com terceiros, principalmente em desenvolvimento e distribuição e na chamada corporação a atividade é de organização de fornecedores, trabalhadores, distribuição, relações com financiadores e governos.

- $\quad$ A empresa A3, embora não tão desenvolvida quanto a A1 em termos de organização já deu alguns passos importantes nesta direção. O desenvolvimento de produtos em Taiwan e a fabricação na China para o mercado dos EUA são alguns dos exemplos mais evidentes.

- $\quad$ A empresa B1 se dedica à avaliação das oportunidades de mercado e organização dos fornecedores para seu aproveitamento. Com isso, pode alterar seu curso e mudar de posição rapidamente.

Este trabalho vai ao encontro do que propõem Humphrey e Schmitz (2000, p. 10), em complemento aos conceitos que foram desenvolvidos por Gereffi. Em relação a produtos industriais padronizados, a atividade de TI pode ser considerada diferenciada. Nos casos estudados, inclusive, há produtos mais diferenciados e aqueles mais padronizados. 
Todas as empresas estudadas estão de formas diferentes, ligadas as GVCs. As empresas A1, A2 e A3 lideram suas respectivas cadeias, ao passo que as cadeias das demais são lideradas por outras empresas. Mesmo as empresas de menor porte, a C1 e a C2, estão ligadas as GVCs, portanto, diferente do que propõe Regnier (2004, p. 160-161). Contudo, em convergência a estas idéias, o fator escala e sua respectiva importância foi mencionado várias vezes, inclusive pelas pequenas empresas. $\mathrm{O}$ fato é que houve registro da importância da escala e como isto estaria mudando o poder de barganha e a governança na rede da qual a empresa participa. A relevância da escala foi citada até mesmo por uma das empresas de menor porte da amostra. Contudo, em nenhum caso houve menção de que o acesso as GVCs tenha sido fácil. Uma das razões da dificuldade é a reputação do Brasil - ou falta dela - na atividade de TI.

Com exceção das empresas B2 e B3, as demais estudadas estão vendendo os produtos com suas próprias marcas. A empresa A3, inclusive, coloca sua marca no produto de terceiros. Um caso no qual pode haver controvérsia é o caso da empresa B1, pois a marca forte da cadeia é da empresa líder. Contudo, mesmo aí se pode afirmar que a empresa não está só vendendo um produto de terceiros, mas procurando e desenvolvendo mercado para seu produto que é a integração de tecnologia avançada com o desenho de soluções, além da busca e organização de fornecedores em todo o mundo.

Com relação à transferência de atividades para o exterior, como destaca Neidik (2004, p. 97), esta tem ocorrido, mas nem sempre o motivador é a redução de custos. O quadro 27, apresentado na seqüência apresenta um comparativo dos motivos que levaram as empresas estudadas a transferirem atividades para o exterior. 
Quadro 27 - Motivos da transferência de atividades ao exterior

\begin{tabular}{|c|c|c|}
\hline EMPRESA & ATIVIDADE / PAÍS & $\begin{array}{c}\text { MOTIVO DA TRANSFERÊNCIA AO } \\
\text { EXTERIOR }\end{array}$ \\
\hline A1 & - Desenvolvimento de software na Argentina & $\begin{array}{l}\text { - Escassez da habilidade necessária para a } \\
\text { atividade no Brasil, custo atraente na } \\
\text { Argentina, além da proximidade deste país } \\
\text { com o Brasil. . }\end{array}$ \\
\hline A2 & $\begin{array}{l}\text { - Desenvolvimento de software na Argentina, } \\
\text { Chile e México. }\end{array}$ & $\begin{array}{l}\text { - Escassez da habilidade necessária para a } \\
\text { atividade no Brasil e custo atraente na } \\
\text { Argentina. }\end{array}$ \\
\hline A3 & $\begin{array}{l}\text { - Desenvolvimento de produtos em Taiwan } \\
\text { - Fabricação na China para o mercado dos EUA } \\
\text { - Acompanhamento de tendências da atividade } \\
\text { de automação comercial na Alemanha } \\
\text { - Desenvolvimento de software na Argentina }\end{array}$ & $\begin{array}{l}\text { - País do mundo com esta competência mais } \\
\text { desenvolvida. } \\
\text { - Custo mais baixo neste país. } \\
\text { - Impossibilidade de fazê-lo do Brasil } \\
\text { (tecnologia da atividade desenvolvida na } \\
\text { Europa). } \\
\text { - Escassez da habilidade necessária para a } \\
\text { atividade no Brasil, custo atraente na } \\
\text { Argentina, além da proximidade deste país } \\
\text { com o Brasil. }\end{array}$ \\
\hline B1 & $\begin{array}{l}\text { - Conexão com fornecedores de países } \\
\text { desenvolvidos }\end{array}$ & $\begin{array}{l}\text { - Inexistência de fornecedores disponíveis no } \\
\text { Brasil }\end{array}$ \\
\hline B2 & - Desenvolvimento de software no México & $\begin{array}{l}\text { - Importância deste mercado para as operações } \\
\text { da empresa, além de escassez da habilidade } \\
\text { necessária para a atividade no Brasil. }\end{array}$ \\
\hline C1 & - Desenvolvimento de software na Índia & - Custo mais baixo. \\
\hline
\end{tabular}

FONTE: AUTOR, 2008, com os conceitos de NEIDIK, 2004, p. 97, aplicados aos casos estudados (informações obtidas na pesquisa de campo).

Nos casos em que há atividade de vendas, operações a clientes e implantação de sistemas no exterior, esta ocorreu pela necessidade de proximidade do comprador na prestação de serviços. Portanto, estes casos não foram indicados no quadro 27. Nos casos em que há ocorrência somente destas atividades, as empresas estudadas não foram indicadas no quadro. Como pode ser observado no quadro 27, o caso da empresa A3 é o único em que há existência somente do fator custo como motivador da transferência da atividade para o exterior. Nos demais casos, inclusive da empresa A3, o que está ocorrendo é a transferência para o exterior em função de alguns motivos, inclusive custo.

Da mesma forma que as conclusões de Dedrick e Kraemer (1998, p. v - vi e p. 278) sobre o setor de informática em países em desenvolvimento, há empresas que são participantes ativos 
do sistema global de produção. O quadro 28, que segue, classifica as empresas estudadas quanto à qualidade de sua participação no sistema global de produção.

\section{Quadro 28 - Qualidade da participação dos casos estudados no sistema global de produção de TI}

\begin{tabular}{|c|c|}
\hline EMPRESA & PARTICIPAÇÃO NO SISTEMA GLOBAL DE PRODUÇÃO DE TI \\
\hline A1 & - Ativa \\
\hline A2 & - Ativa \\
\hline A3 & - Ativa \\
\hline B1 & - Sua participação é importante, embora não seja a líder da cadeia da qual participa. Pode-se \\
falar em ativa regionalmente (América Latina).
\end{tabular}

FONTE: AUTOR, 2008, com informações sobre os casos estudados obtidas em pesquisa de campo.

Portanto, três das oito empresas estudadas possuem participação ativa nas cadeias das quais participam. A qualidade do papel desempenhado possivelmente está relacionada às características do produto. As três empresas que possuem participação ativa estão envolvidas com a atividade de software de gestão. Contudo, as empresas C1 e C2 também estão envolvidas com software de gestão. No caso da C1, a qualificação pode estar relacionada ao fato do mercado em que atua ser concentrado; ou seja, os compradores são poderosos. No caso da empresa C2, seu papel não é ativo em função da existência de um fornecedor poderoso, que lidera a cadeia. O caso da empresa B1 é interessante, pois a empresa desempenha um papel ativo na região, embora em termos globais a cadeia seja liderada por uma empresa dos EUA. As empresas B2 e B3 são aquelas cujo papel na cadeia é menos ativo.

Em linha com a idéia colocada por Humphrey e Schmitz (2000, p. 1) a empresa C2 opera em uma cadeia global do tipo quasi-hierárquica e a própria organização reconhece que isto lhe tem ajudado no aperfeiçoamento do produto. Na verdade, no curto prazo, a empresa não tem 
condições de progredir para outras funções da cadeia. No caso das empresas B2 e B3, estas estão em cadeias globais lideradas pelos compradores. A empresa B3 mencionou com bastante ênfase a migração para produtos mais sofisticados. A empresa B2, visto o desenvolvimento de um centro de desenvolvimento de software no México, também parece estar logrando desempenhar funções mais sofisticadas na cadeia. A empresa B1 mostrou estar bem consciente quanto às limitações de suas possibilidades de aperfeiçoamento: foi afirmado que a empresa sabe que é uma relação frágil. Embora neste caso, ocorra a operação em uma cadeia que, dentre as das empresas estudadas é a que mais se aproxima de uma rede, não obstante a liderança da empresa dos EUA, Com relação ao apoio de instituições locais, além do apoio do governo através de BNDES e FINEP (Financiadora de Estudos e Projetos, empresa pública ligada ao Ministério da Ciência e Tecnologia do Brasil), há o investimento das empresas estudadas no aperfeiçoamento.

De forma a discutir a atuação dos casos estudados com as idéias de Bell e Albu (1999, p. 1715) e Humphrey e Schmitz (2000, p. 19) sobre alteração do conhecimento e necessidade de investimentos específicos em marketing e relação com os fornecedores, pode-se afirmar que: - $\quad$ A empresa A1, com seu sistema de franquias de desenvolvimento e distribuição e uma corporação que dirige esta cadeia com pouco mais de 150 funcionários, pode ser qualificada de inovadora em termos organizacionais.

- $\quad$ A empresa A3 com a busca de se envolver em locais onde esteja o estado da arte no mundo na atividade, seja de desenvolvimento de produto, seja em tecnologia e com a oferta de uma solução completa em automação comercial (hardware, software e serviços) também se destaca entre as estudadas.

- $\quad$ A empresa B1, ao participar de uma organização em rede, desempenhando papel ativo em termos regionais e ao mesmo tempo procurando identificar as tendências de forma a se preparar de forma antecipada parece atuar de forma incomum na América Latina.

- $\quad$ As empresas C1 e C2 efetuaram alterações de produtos, que são importantes, mas são outro aspecto da inovação.

- $\quad$ A empresa A2 tem na sua atuação a inteligência de marketing como destaque ao se estabelecer no segmento das PMEs, ao qual as empresas internacionais de maior porte dedicaram pouca atenção. 
Dentre os casos estudados somente no caso da empresa A1 foi identificada uma relação que tem características de uma rede. No caso da empresa C1, também existe uma rede, no nível das pessoas físicas, mas que não tem características operacionais, como no caso B1. Portanto, embora este estudo não tenha validade estatística, se confirma a escassez de casos que exemplifiquem as relações do tipo rede. Contudo, mesmo neste caso, a rede não envolve os compradores dos produtos, mas somente os demais ofertantes.

As ligações do caso A1 são semelhantes àquelas descritas por Dedrick e Kraemer (1998, p. 225) para o Japão e a Coréia para o setor de informática. A diferença é que a empresa brasileira não é um keiretsu ou um chaebol, como o que existe no Japão e na Coréia. As empresas C1 e C2, nas suas respectivas ligações com as redes produtivas globais, atuam com semelhança à rede produtiva de Taiwan, exceto pelo fato de que não vendem somente para compradores multinacionais (MNCs). Nos dois casos há compradores no mercado interno. Aliás, embora não seja o foco deste trabalho, deve ser registrada a importância que muitas das empresas entrevistadas atribuíram ao mercado interno do Brasil. Nos casos das empresas C1 e C2 deve ser notada a coincidência com o caso de Taiwan no histórico dos empreendedores, ex-funcionários de grandes empresas. Não se pode falar, contudo, nos dois casos em seguidor ágil, pois as duas empresas desenvolveram produtos inovadores. Nos demais casos, as ligações com as redes produtivas globais parecem se assemelhar as de Hong Kong, na qual há uma combinação de fornecedores domésticos, multinacionais baseadas no país e em alguns casos fornecedores externos, como nos casos A3 e B1. As empresas A2 e A3 seriam casos especiais que cresceram a ponto de governar uma rede.

O fato de que no software os compradores precisam sentir segurança foi mencionada por várias empresas entrevistadas. Neste ponto, pode estar contribuindo para o sucesso das empresas A1, A2, A3 e C1 o fato de no Brasil o mercado de capitais ter se desenvolvido enormemente nos últimos anos (A1, A2 e A3 são de capital aberto) e todas terem contado ou ainda contarem com o apoio do capital de risco. Na Ásia, por exemplo, a proteção da propriedade intelectual foi mencionada como problema por alguns entrevistados. Contudo, ao contrário da Ásia, a sofisticação dos usuários e a percepção do valor do software para os usuários domésticos, diferente do que apontam Dedrick e Kraemer (1998, p. 223-224 e 226228) para a Ásia, estão presentes no Brasil. A proximidade dos usuários principais foi notada nas empresas C1 e C2, voltadas a softwares para o setor financeiro. A região do Sul do Brasil pode ser caracterizada como um pólo de TI, mas as empresas A1 e B2, que tem nesta região 
sua origem, mantêm forte presença na região metropolitana de São Paulo. Todas as empresas estudadas desenvolveram seus produtos para o mercado brasileiro e depois os comercializaram no exterior.

O quadro 29, exibido na seqüência, apresenta as alavancas de poder nos casos estudados, abordagem utilizada por Kaplinsky e Morris (2003, p. 44). 
Quadro 29 - Componentes da renda e barreiras à entrada

\begin{tabular}{|c|c|c|}
\hline EMPRESA & COMPONENTES DA RENDA & BARREIRAS À ENTRADA \\
\hline A1 & $\begin{array}{l}\text { - Licença de uso dos produtos. Evolução para o } \\
\text { modelo de SaaS. }\end{array}$ & $\begin{array}{l}\text { - Atuação agressiva dos canais de distribuição } \\
\text { e entrega do que é contratado. } \\
\text { - Envolvimento em atividades que envolvam } \\
\text { inteligência e/ou sejam de alta complexidade. } \\
\text { - Ciclo de desenvolvimento e consolidação do } \\
\text { software (longo). } \\
\text { - Investimentos realizados pelo comprador no } \\
\text { sistema. }\end{array}$ \\
\hline A2 & - Licença de uso dos produtos. & $\begin{array}{l}\text { - Ciclo de desenvolvimento e consolidação do } \\
\text { software (longo). } \\
\text { - Conhecimento adquirido para atuação no } \\
\text { segmento das PMEs. } \\
\text { - Gestão da distribuição. } \\
\text { - Investimentos realizados pelo comprador no } \\
\text { sistema. }\end{array}$ \\
\hline A3 & $\begin{array}{l}\text { - Venda de equipamentos. } \\
\text { - Venda de licenças de uso de softwares. } \\
\text { - Serviços prestados }\end{array}$ & $\begin{array}{l}\text { - Completude da solução, qualidade do } \\
\text { produto e da atuação no canal de distribuição, } \\
\text { bem como intensidade neste último caso e } \\
\text { reconhecimento da marca. }\end{array}$ \\
\hline B1 & $\begin{array}{l}\text { - Desenho de soluções para integração de } \\
\text { tecnologia avançada, atividade que compreende } \\
\text { a gestão de um grupo de fornecedores atuando } \\
\text { em rede. }\end{array}$ & $\begin{array}{l}\text { - Competência para a montagem das redes. } \\
\text { - Sofisticação da atividade. }\end{array}$ \\
\hline B2 & $\begin{array}{l}\text { Prestação de serviços de: } \\
\text { - Consultoria (20\%) } \\
\text { - Desenvolvimento e integração de sistemas } \\
(20 \%) \\
\text { - Outsourcing }(60 \%)\end{array}$ & - Escala \\
\hline B3 & - Prestação de serviços de TI e BPO. & $\begin{array}{l}\text { - Eficiência operacional } \\
\text { - Escopo da oferta de produtos }\end{array}$ \\
\hline C1 & - Licença de uso dos produtos & $\begin{array}{l}\text { - Utilização do estado da arte da tecnologia, } \\
\text { relacionamento com compradores e rapidez } \\
\text { com qualidade. }\end{array}$ \\
\hline $\mathrm{C} 2$ & - Licença de uso dos produtos & $\begin{array}{l}\text { - Prática de preços baixos com lucro em } \\
\text { função de custos baixos }\end{array}$ \\
\hline
\end{tabular}

FONTE: AUTOR, 2008, com conceitos de KAPLINSKY; MORRIS, 2003, p. 44, aplicados aos casos estudados (informações sobre os casos obtidas em pesquisa de campo e em fontes secundárias de dados).

De forma a utilizar os conceitos de Kaplinsky e Morris (2003, p. 44) e também de Gibbon e Ponte (2005, p. 87-88), pode ser considerado que há ocorrência de aperfeiçoamento competitivo nas empresas A3, B1 e B3. A empresa A3 mudou de função na cadeia, pois se 
limitava ao hardware e incorporou o software a sua oferta. Sobre o fato de ser uma função mais rentável, ainda não é possível afirmar isto, em virtude da empresa estar implantando seus procedimentos de gestão ao software. No caso da empresa B1, esta busca permanentemente evoluir para funções mais rentáveis, o que significa se preparar para a próxima “onda tecnológica” como define o executivo entrevistado. Esta busca implica algumas vezes em mudar de cadeia de valor. A empresa B3 vê com clareza quais são as funções mais rentáveis e quais são as menos rentáveis. Esta organização estudada procura evoluir para as mais rentáveis e usa as menos rentáveis para bloquear a entrada de concorrentes e para começar a atuar em novos clientes com vistas a evoluir para as mais rentáveis.

Na maior parte dos casos houve menção à questão da escala que é um paradigma do modo de produção fordista. A empresa que atua mais claramente em um paradigma pós fordista é a B1, pois seu modelo apresenta alta flexibilidade. As empresas B2 e B3 são as que têm os produtos menos diferenciados da amostra e contam com a força de trabalho menos capacitada.

Contudo, nas duas organizações foi detectado um esforço para fazer a experiência dos funcionários mais interessante, que é uma característica do fordismo.

No tocante ao conceito apresentado por Gibbon e Ponte (2005, p. 138), de marginalização competitiva, os casos B2 e B3 precisam ter atenção a este ponto. A empresa B3 mencionou empenho neste sentido de forma explícita e espontânea. A empresa que se destaca, no sentido de se afastar da marginalização competitiva é a B1. O que chama a atenção neste caso é que a empresa tem atuado neste sentido, com sucesso, já há alguns anos.

Nos casos estudados, ao se utilizar as métricas propostas por Buckley et al (1988, p. 176-180 e p. 191-192), nota-se que:

1. A participação de mercado na exportação é baixa, exceto no caso da empresa A2 que tem participação de mercado na América Latina ao redor de 17\% em software de gestão, estando entre as três organizações líderes na atividade.

2. Em todas as organizações estudadas, a participação das exportações na receita total está abaixo de 30\%, mal chegando a 5\% em alguns dos casos.

3. Contudo, há casos de crescimento das exportações, com tendência de concentração naquelas empresas e produtos onde há menor dependência do custo da mão-de-obra para a competitividade. 
Em todos os casos estudados foi verificado o compromisso com os negócios internacionais. De acordo com Buckley et al (1988, p. 176-180 e p. 191-192), este é um dos aspectos da tarefa dos gestores.

Em termos das idéias de Barney (1991, p. 102-103) sobre vantagem competitiva, foi observado o seguinte na pesquisa de campo:

- $\quad$ A empresa A1 desenvolveu uma estratégia de criação de valor que se baseia no estímulo empreendedor aos desenvolvedores e aos participantes do canal de distribuição. - $\quad$ A empresa A2 logrou obter vantagem competitiva no segmento das PMEs, cuja abordagem pela concorrência pode ser classificada de difícil.

- $\quad$ A empresa A3 desenvolveu uma estratégia de criação de valor baseada na completude de sua solução. A empresa atua simultaneamente em várias GVCs.

- $\quad$ A empresa B1 cria valor através da constante atenção à evolução da tecnologia e se prepara para atuar de forma diferente.

- $\quad$ A empresa B2 avalia que sua vantagem competitiva é a flexibilidade e também a escala das operações.

- $\quad$ A empresa B3 entende que sua vantagem competitiva é a operação eficiente - foi utilizado o termo lean - obtido a custa de planejamento intenso.

- $\quad$ A empresa $\mathbf{C 1}$ cria valor através da completude de sua solução para empresas financeiras. Esta é uma vantagem competitiva que a empresa avalia que tem.

- $\quad$ A empresa C2 interpreta que sua vantagem competitiva está também na completude da solução oferecida, em conjunto com as características inovadoras do produto.

Em termos de aprendizado e aperfeiçoamento, de forma a utilizar o que destacam Kaplinsky e Morris (2003, p. 24 e p. 37), segue um perfil sobre os casos estudados neste aspecto:

- $\quad$ A mudança organizacional implementada pela empresa A1 em 1999 é algo que merece destaque em termos de aprendizado.

- $\quad$ Pode-se falar em aperfeiçoamento competitivo no caso da empresa A3, visto a inclusão de softwares de aperfeiçoamento comercial na sua oferta. Também se pode falar em aprendizado neste caso no desenvolvimento de produtos no exterior, fabricação na China para o mercado dos EUA e incorporação de produtos de terceiros com a marca da empresa a sua oferta. 
- $\quad$ A empresa B1 coloca como padrão de sua atuação o aprendizado. Já houve várias mudanças de atividade e a empresa se prepara para mudar novamente no futuro.

- $\quad$ No caso da empresa B3, esta tem se empenhado para migrar para produtos mais sofisticados, que lhe possibilitem maiores rendas. Com relação a aprendizado e mudança, a avaliação dos entrevistados é que a estrutura já se acostumou com as freqüentes mudanças.

A empresa A1 também mencionou explicitamente o empenho em se movimentar para “camadas competitivas” de maior complexidade, onde se pode obter renda mais alta. Neste caso foi mencionado o dinamismo existente, onde há permanente movimentação das atividades. A avaliação é que se a empresa fica parada, será deslocada para atividades de menor complexidade e renda.

Com relação às colocações de Kaplinsky e Morris (2003, p. 37-38), foi verificado em um dos casos que há consciência de que as atividades que potencialmente geram mais renda são aquelas mais próximas da atividade fim do comprador. Com relação à singularidade, foi algo que também há consciência. Contudo, várias vezes foi mencionado que, do ponto de vista tecnológico a conquista e manutenção de singularidade é difícil. As empresas B2 e B3 alegam ser difícil a colocação de barreiras à entrada. Uma barreira, especialmente no caso destas empresas é a escala. As empresas A1 e A2 desenvolveram barreiras à entrada relacionadas aos seus sistemas de distribuição.

Quanto ao dinamismo, a empresa A1 está mais bem posicionada neste aspecto, pois seu sistema de franquias é mais flexível que o sistema integrado verticalmente de desenvolvimento e distribuição da empresa A2. Embora no curto prazo, a hierarquia da A2 possa trazer resultados melhores em função da amortização de custos fixos. A empresa A3 também tem revisto as atividades que desenvolve. Dentre as atividades a que renunciou estão o desenvolvimento de produtos e a fabricação. Quanto ao desenvolvimento de produtos, este é realizado em Taiwan. A fabricação ainda é feita no Brasil, mas a empresa começa a fabricar na China, por exemplo, para o mercado dos EUA. A empresa B1 é um exemplo de prontidão para renúncia a atividades que foi excelente no passado. Pareceu claro que a empresa baseia sua atuação nesta idéia de evolução constante. Nestes três casos, A1, A3 e B1, a avaliação é que os processos internos facilitam o aprendizado. As três empresas parecem ter a capacidade de rever atividades que eram desenvolvidas no passado e continuar a fazê-lo no futuro. 
Quanto à remodelagem, a empresa B3 também deu mostras de fazê-lo e continuar preparada para tal, embora o seu porte e o escopo de suas atividades não ajudem neste sentido.

Não foram encontradas evidências de que, a exemplo do que ocorre na Índia, conforme apontado por Ambastha e Momaya (2004, p. 46-50), houvesse falta de compreensão da integração entre competitividade e estratégia. Com as conclusões de Maskell e Malmberg (1999, p. 179-181) as empresas B2 e B3 parecem bastante focadas na obtenção de eficiência. Diferente dos casos A3 e B1 onde parece haver aprendizado constante. O caso A1 também deve ser notado, pois a reorganização pela qual passou em 1999 pode ser classificada como uma forma de aprendizado. As contínuas reorganizações da empresa B3, se devidamente conectadas a uma estratégia que levasse em conta não somente escala e operação eficiente também poderia ser considerada uma evidência de aprendizado.

O caso mais notável dentre os estudados de forma tácita de conhecimento e capacidade de se desconectar de sua própria história é o da empresa B1. A empresa C1, na rede de pessoas físicas em vários países do mundo, que troca experiências e informações, também pode ser notado como evidência de que há envolvimento com uma rede na qual circula conhecimento não codificado.

Os quadros 30 e 31, que seguem, trazem aspectos das empresas estudadas quanto às formas de obtenção da competitividade. 
Quadro 30 - Formas de obtenção da competitividade pelos casos estudados - PORTE

\begin{tabular}{|c|c|c|c|c|c|c|}
\hline \multirow[b]{2}{*}{ EMPRESA } & \multicolumn{6}{|c|}{ VANTAGENS DE PORTE E PODER DE MERCADO } \\
\hline & Muito alta & Alta & $\begin{array}{c}\text { Discretamente } \\
\text { alta }\end{array}$ & $\begin{array}{c}\text { Discretamente } \\
\text { baixa }\end{array}$ & Baixa & Muito baixa \\
\hline A1 & & & $\mathbf{x}$ & & & \\
\hline A2 & & & $\mathbf{X}$ & & & \\
\hline A3 & $\mathbf{x}$ & & & & & \\
\hline B1 & & & & & $\mathbf{x}$ & \\
\hline B2 & & $\mathbf{X}$ & & & & \\
\hline B3 & $\mathbf{X}$ & & & & & \\
\hline C1 & & & $\mathbf{X}$ & & & \\
\hline C2 & & & & & $\mathbf{x}$ & \\
\hline
\end{tabular}

FONTE: AUTOR, 2008, com conceitos de RUGMAN; D’CRUZ, 2000, p. 80-81, aplicados aos casos estudados a partir de informações obtidas em pesquisa de campo.

Quadro 31 - Formas de obtenção da competitividade pelos casos estudados FLEXIBILIDADE

\begin{tabular}{|c|c|c|c|c|c|c|}
\hline \multirow[b]{2}{*}{ EMPRESA } & \multicolumn{6}{|c|}{ FLEXIBILIDADE E ADAPTABILIDADE DA REDE } \\
\hline & Muito alta & Alta & $\begin{array}{c}\text { Discretamente } \\
\text { alta }\end{array}$ & $\begin{array}{c}\text { Discretamente } \\
\text { baixa }\end{array}$ & Baixa & Muito baixa \\
\hline A1 & & $\mathbf{x}$ & & & & \\
\hline A2 & & & $\mathbf{X}$ & & & \\
\hline A3 & & $\mathbf{X}$ & & & & \\
\hline B1 & $\mathbf{X}$ & & & & & \\
\hline B2 & & & & $\mathbf{x}$ & & \\
\hline B3 & & & & & $\mathbf{x}$ & \\
\hline C1 & & & & $\mathbf{x}$ & & \\
\hline C2 & & & & $\mathbf{X}$ & & \\
\hline
\end{tabular}

FONTE: AUTOR, 2008, com conceitos de RUGMAN; D’CRUZ, 2000, p. 80-81, aplicados aos casos estudados a partir de informações obtidas em pesquisa de campo.

A classificação das empresas foi realizada pelo autor, subjetivamente, com base nas informações coletadas na pesquisa de campo. Somente das empresas A1, A3 e B1, pode-se 
dizer que contam com flexibilidade e adaptabilidade alta de sua rede. A empresa A1 devido à rede de franquias de distribuição e desenvolvimento. A empresa A3 devido à forma de desenvolvimento de produto e fabricação. Esta empresa é incomum, pois combina flexibilidade e adaptabilidade da rede com as vantagens do porte e do poder de mercado. A empresa B1 devido à sua participação no ecossistema da empresa dos EUA e, principalmente, à abordagem pró ativa quanto à evolução da tecnologia para busca de novas formas de atuação. As empresas B2, B3, C1 e C2 foram tiveram a flexibilidade e adaptabilidade classificadas como baixas, ainda que discretamente em três dos quatro casos. A empresa C2, não obstante esta classificação, também não desfruta das vantagens do porte. Pode não ser negativo, pois conta com mais graus de liberdade do que se usufruísse das vantagens do porte e do poder de mercado. A empresa B2, baseia sua atuação na flexibilidade. Pode ser que se fosse de porte maior, como é a B3, operacionalizar esta flexibilidade ficasse inviável. As empresas A3 e B1 parecem combinar esta flexibilidade e adaptabilidade à competitividade nas tecnologias líderes de suas respectivas atividades. No caso da empresa B1 pode-se inclusive adicionar o conceito de dinamismo, que também existe na A3.

As empresas A1, A2, A3 e B1 parecem combinar o conhecimento da tecnologia para o desenvolvimento de produtos com o conhecimento relacionado à gestão das organizações, a exemplo do que mencionam Lane e Probert (2006, p. 38).

Quanto ao modelo de Kaplinsky (2005, p. 89) para a obtenção da vantagem competitiva no nível empresarial, a empresa B1 parece compreender claramente a necessidade de mudança, o que modela a estratégia do negócio. A empresa B3, embora compreenda a necessidade da mudança, isto se dá mais no aspecto da estrutura organizacional. A empresa A1 mudou com sucesso, isto influenciou a estratégia do negócio, mas talvez falte um estado de revisão permanente, como o encontrado na empresa B1.

A empresa A3 chama a atenção, pois não procura competir e preços. Foi declarado que são praticados preços premium. Se for considerado que esta empresa possui a liderança do mercado brasileiro em automação comercial, com participações de mercado que chegam a ultrapassar os $60 \%$, pode-se afirmar que esta empresa conseguiu capturar a preferência do comprador. Sobre as características que mantém as altas rendas, visto que não foi feita pesquisa com os compradores para investigação deste item, pode-se apenas especular que a 
completude da solução, a confiabilidade dos produtos e a intensidade na distribuição estão entre estas características.

Houve adesão no que prega a teoria quanto à atuação voltada para os segmentos. Este aspecto foi encontrado em todas as empresas estudadas. Não se chegou ao nível de avaliar a qualidade dos segmentos e o quanto os produtos aderem às características destes.

O quadro 32, que segue, traz uma classificação dos casos estudados a partir de informações obtidas na pesquisa de campo. Esta classificação é feita quanto ao tempo de resposta, flexibilidade em termos de aceitar pedidos pequenos, inovação (organização, marketing e outras formas de competir) e adaptabilidade no sentido de rearranjar e transformar a organização. Estes aspectos são propostos por Schmitz e Knorringa (1999, p. 6), Porter e Wayland (1995, p. 2), Williamson (1991A, p. 278) e Teece et al (1997, p. 521).

\begin{tabular}{|c|c|c|c|}
\hline CASO & $\begin{array}{l}\text { FLEXIBILIDADE } \\
\text { PARA PEDIDOS } \\
\text { PEQUENOS }\end{array}$ & $\begin{array}{c}\text { INOVAÇÃO } \\
\text { EM ORGANIZAÇÃO, } \\
\text { MARKETING E } \\
\text { OUTRAS FORMAS }\end{array}$ & $\begin{array}{l}\text { CAPACIDADE } \\
\text { DE } \\
\text { ADAPTAÇÃO }\end{array}$ \\
\hline A1 & $\begin{array}{c}\text { DISCRETAMENTE } \\
\text { BAIXA }\end{array}$ & ALTA & ALTA \\
\hline A2 & ALTA & $\begin{array}{c}\text { DISCRETAMENTE } \\
\text { ALTA }\end{array}$ & $\begin{array}{c}\text { DISCRETAMENTE } \\
\text { BAIXA }\end{array}$ \\
\hline A3 & ALTA & ALTA & ALTA \\
\hline B1 & $\begin{array}{c}\text { DISCRETAMENTE } \\
\text { BAIXA }\end{array}$ & ALTA & ALTA \\
\hline B2 & $\begin{array}{c}\text { DISCRETAMENTE } \\
\text { BAIXA }\end{array}$ & $\begin{array}{l}\text { DISCRETAMENTE } \\
\text { ALTA }\end{array}$ & $\begin{array}{c}\text { DISCRETAMENTE } \\
\text { ALTA }\end{array}$ \\
\hline B3 & BAIXA & $\begin{array}{c}\text { DISCRETAMENTE } \\
\text { ALTA }\end{array}$ & $\begin{array}{c}\text { DISCRETAMENTE } \\
\text { ALTA }\end{array}$ \\
\hline C1 & $\begin{array}{c}\text { DISCRETAMENTE } \\
\text { ALTA }\end{array}$ & $\begin{array}{c}\text { DISCRETAMENTE } \\
\text { ALTA }\end{array}$ & $\begin{array}{c}\text { DISCRETAMENTE } \\
\text { ALTA }\end{array}$ \\
\hline C2 & $\begin{array}{c}\text { DISCRETAMENTE } \\
\text { ALTA }\end{array}$ & BAIXA & $\begin{array}{c}\text { DISCRETAMENTE } \\
\text { ALTA }\end{array}$ \\
\hline
\end{tabular}

FONTE: AUTOR, 2008, com conceitos de SCHMITZ; KNORRINGA, 1999, p. 6; PORTER; WAYLAND 1995, p. 2; WILLIAMSON, 1991A, p. 278 e TEECE ET AL, 1997, p. 521 aplicados aos casos estudados (informações coletadas na pesquisa de campo). 
Os casos estudados foram classificados subjetivamente pelo autor, com base no conteúdo obtido na pesquisa de campo. Estes aspectos não foram indagados diretamente, pois como propõem Schmitz e Knorringa (1999, p. 6), deve-se evitar que os entrevistados respondam com clichês. A posição da empresa A3 chama a atenção, sendo que pode ser destacada a posição das organizações A1 e B1.

No entanto, em todos os casos as empresas produzem tentando prever o que o comprador deseja, diferente do que aponta Kaplinsky (2005, p. 92-95) para o que seria o novo paradigma.

Com relação aos tipos de aperfeiçoamento competitivo, o que foi constatado na pesquisa com referência aos casos estudados pode ser visualizado no quadro 33, exibido a seguir. 
Quadro 33 - Classificação dos casos quanto ao aperfeiçoamento competitivo

\begin{tabular}{|c|c|c|c|c|c|}
\hline \multirow[b]{2}{*}{ CASO } & \multicolumn{4}{|c|}{ TIPO DE APERFEIÇOAMENTO } & \multirow[b]{2}{*}{$\begin{array}{l}\text { EVENTO DEFINIDOR DA } \\
\text { CLASSIFICAÇÃO }\end{array}$} \\
\hline & PROCESSO & PRODUTO & FUNCIONAL & $\begin{array}{l}\text { INTER- } \\
\text { SETORIAL }\end{array}$ & \\
\hline A1 & $\mathbf{X}$ & & & & $\begin{array}{l}\text { Reorganização com criação das } \\
\text { franquias de desenvolvimento e } \\
\text { distribuição. }\end{array}$ \\
\hline A2 & & $\mathbf{x}$ & & & $\begin{array}{l}\text { Ocorreu com a compra ou } \\
\text { desenvolvimento de soluções novas, } \\
\text { como softwares de gestão do tipo } \\
\text { CRM, BI, SCM e os chamados } \\
\text { módulos verticais (específicos para } \\
\text { um setor). }\end{array}$ \\
\hline A3 & & $\begin{array}{c}\mathbf{X} \\
(1)\end{array}$ & $\begin{array}{c}\mathbf{X} \\
(2)\end{array}$ & & $\begin{array}{l}\text { (1) Passou a desenvolver e } \\
\text { comercializar software, um produto } \\
\text { mais sofisticado do que o hardware } \\
\text { (que possui software embarcado). } \\
\text { (2) Ao incorporar produtos de } \\
\text { terceiros a sua linha, ficando } \\
\text { responsável pelo design e pelo } \\
\text { marketing. } \\
\text { (2) Ao passar a desenvolver produtos } \\
\text { em Taiwan e fabricar na China, } \\
\text { ficando com a responsabilidade } \\
\text { apenas do projeto e da coordenação } \\
\text { da cadeia. }\end{array}$ \\
\hline B1 & & $\mathbf{x}$ & & & $\begin{array}{l}\text { Movimentação constante na direção } \\
\text { de produtos mais sofisticados. }\end{array}$ \\
\hline B2 & $\begin{array}{c}\mathbf{X} \\
(1)\end{array}$ & $\begin{array}{l}\mathbf{X} \\
(2)\end{array}$ & & & $\begin{array}{l}\text { (1) Busca constante de eficiência } \\
\text { e aumento da produtividade. Foco na } \\
\text { gestão de pessoas. } \\
\text { (2) Criação de novos produtos } \\
\text { que às vezes nem envolvem com } \\
\text { intensidade o uso de tecnologia }\end{array}$ \\
\hline B3 & $\begin{array}{c}\mathbf{X} \\
(1)\end{array}$ & $\begin{array}{c}\mathbf{X} \\
(2)\end{array}$ & & & $\begin{array}{l}\text { (3) Busca de eficiência } \\
\text { operacional através de planejamento } \\
\text { detalhado das operações. } \\
\text { (4) Desenvolvimento de novos } \\
\text { produtos - às vezes com a compra de } \\
\text { empresas - de maior sofisticação e } \\
\text { que possibilitam mais renda. }\end{array}$ \\
\hline C1 & $\mathbf{X}$ & & & & $\begin{array}{l}\text { Reorganização com as fusões para } \\
\text { aumento da eficiência e da eficácia } \\
\text { sem perda de capital intelectual. } \\
\text { Criação de unidades de negócios } \\
\text { com autonomia. Funções } \\
\text { centralizadas são planejamento e } \\
\text { controle. }\end{array}$ \\
\hline C2 & & $\mathbf{X}$ & & & $\begin{array}{l}\text { Aperfeiçoamento de produto a partir } \\
\text { de relacionamento com o exterior. }\end{array}$ \\
\hline
\end{tabular}


FONTE: AUTOR, 2008, com conceitos de HUMPHREY; SCHMITZ, 2000, p. 3-4, aplicados aos casos estudados, classificados com base nas informações obtidas em pesquisa de campo.

Embora existam críticas à ênfase colocada por Humphrey e Schmitz (2000, p. 3-4) no aperfeiçoamento funcional (GIBBON E PONTE, 2005, p. 89-90), este só foi observado no caso da empresa B3. Esta empresa parece ser a líder de sua cadeia. Embora, a cadeia seja a mesma para o hardware e para o software de automação comercial, se a empresa não abdicou das funções anteriores, pelo menos diminuiu sua atuação nelas. Contudo, este evento não pode ser considerado negativo, pois as novas funções são mais sofisticadas que as anteriores. Sobre este tipo de aperfeiçoamento ser melhor do que os demais, se utilizadas as métricas de resultados e valor de mercado, esta empresa, conforme notícia publicada na imprensa do Brasil, não é bem sucedida: seu valor de mercado desde a Oferta Pública de Ações (OPA), diminuiu mais de $50 \%$.

Os quadros 34 e 35, na seqüência, trazem exemplos de indicadores de inovação e aperfeiçoamento competitivo para os casos estudados, conforme proposto por Kaplinsky e Morris (2003, p. 77). 
Quadro 34 - Exemplos de indicadores de inovação e aperfeiçoamento competitivo nos casos estudados - PRÁTICAS

\begin{tabular}{|c|c|c|c|c|c|c|c|c|}
\hline \multicolumn{2}{|c|}{$\begin{array}{c}\text { TIPOS DE } \\
\text { APERFEIÇOAMENTO }\end{array}$} & A1 & A2 & A3 & B1 & B2 & B3 & C1 \\
\hline $\begin{array}{l}\text { MELHORA } \\
\text { DA } \\
\text { EFICIÊNCIA } \\
\text { DOS } \\
\text { PROCESSOS }\end{array}$ & $\begin{array}{l}\text { Dentro } \\
\text { da } \\
\text { cadeia } \\
\text { Entre } \\
\text { os elos } \\
\text { da } \\
\text { cadeia }\end{array}$ & $\begin{array}{l}\text {-Altera em } \\
\text { logística } \\
\text {-Gestão da } \\
\text { cadeia de } \\
\text { suprimento }\end{array}$ & & & & $\begin{array}{l}\text {-Altera em } \\
\text { práticas } \\
\text { relacionadas } \\
\text { à qualidade }\end{array}$ & $\begin{array}{l}\text {-Altera em } \\
\text { logística } \\
\\
\text { - Gestão da } \\
\text { cadeia de } \\
\text { suprimentos }\end{array}$ & $\begin{array}{l}\text {-Altera } \\
\text { prática } \\
\text { relacionada } \\
\text { à qualidade }\end{array}$ \\
\hline $\begin{array}{l}\text { INTRODUÇÃO } \\
\text { DE NOVOS } \\
\text { PRODUTOS } \\
\text { OU } \\
\text { MELHORA DE } \\
\text { PRODUTOS } \\
\text { EXISTENTES }\end{array}$ & $\begin{array}{l}\begin{array}{l}\text { Dentro } \\
\text { da } \\
\text { cadeia }\end{array} \\
\text { Entre } \\
\text { os elos } \\
\text { da } \\
\text { cadeia }\end{array}$ & & $\begin{array}{l}\text {-Criação } \\
\text { de } \\
\text { novos } \\
\text { produtos }\end{array}$ & $\begin{array}{l}\text {-Criação de } \\
\text { novos produtos } \\
\\
\text {-Cooperação } \\
\text { com } \\
\text { fornecedores } \\
\text { para } \\
\text { desenvolvimento } \\
\text { de novos } \\
\text { produtos }\end{array}$ & $\begin{array}{l}\text {-Criação } \\
\text { de } \\
\text { novos } \\
\text { produtos }\end{array}$ & $\begin{array}{l}\text {-Criação de } \\
\text { novos } \\
\text { produtos }\end{array}$ & $\begin{array}{l}\text {-Criação de } \\
\text { novos } \\
\text { produtos }\end{array}$ & \\
\hline $\begin{array}{l}\text { ALTERAÇÃO } \\
\text { NAS } \\
\text { ATIVIDADES }\end{array}$ & $\begin{array}{l}\begin{array}{l}\text { Dentro } \\
\text { da } \\
\text { cadeia }\end{array} \\
\text { Entre } \\
\text { os elos } \\
\text { da } \\
\text { cadeia }\end{array}$ & & & $\begin{array}{l}\text {-Terceirização } \\
\text { de atividades } \\
\text { que adicionam } \\
\text { pouco valor. } \\
\text {-Movimentação } \\
\text { para novos elos } \\
\text { das cadeias }\end{array}$ & & & & \\
\hline
\end{tabular}

FONTE: AUTOR, 2008, com conceitos de KAPLINSKY; MORRIS, 2003, p. 77, aplicados aos casos estudados, classificados com base nas informações obtidas em pesquisa de campo. 
Quadro 35 - Exemplos de indicadores de inovação e aperfeiçoamento competitivo nos casos estudados - DESEMPENHO

\begin{tabular}{|c|c|c|c|c|c|c|c|c|}
\hline \multicolumn{2}{|c|}{$\begin{array}{c}\text { TIPOS DE } \\
\text { APERFEIÇOAMENTO } \\
\end{array}$} & A1 & A2 & A3 & B1 & B2 & B3 & C1 \\
\hline $\begin{array}{l}\text { MELHORA } \\
\text { DA } \\
\text { EFICIÊNCIA } \\
\text { DOS } \\
\text { PROCESSOS }\end{array}$ & $\begin{array}{l}\begin{array}{l}\text { Dentro } \\
\text { da } \\
\text { cadeia }\end{array} \\
\text { Entre } \\
\text { os elos } \\
\text { da } \\
\text { cadeia }\end{array}$ & $\begin{array}{l}\text {-Tempo para } \\
\text { o mercado } \\
\text { diminuído } \\
\text {-Aumento } \\
\text { da } \\
\text { lucratividade } \\
\text { em toda a } \\
\text { cadeia de } \\
\text { valor }\end{array}$ & & & & $\begin{array}{l}\text {-Custos + } \\
\text { baixos }\end{array}$ & $\begin{array}{l}\text {-Custos + } \\
\text { baixos e } \\
\text { melhora do } \\
\text { desempenho } \\
\text { de entrega }\end{array}$ & $\begin{array}{l}- \\
\text { Custos } \\
+ \\
\text { baixos }\end{array}$ \\
\hline $\begin{array}{l}\text { INTRODUÇÃO } \\
\text { DE NOVOS } \\
\text { PRODUTOS } \\
\text { OU } \\
\text { MELHORA DE } \\
\text { PRODUTOS } \\
\text { EXISTENTES }\end{array}$ & $\begin{array}{l}\begin{array}{l}\text { Dentro } \\
\text { da } \\
\text { cadeia }\end{array} \\
\text { Entre } \\
\text { os elos } \\
\text { da } \\
\text { cadeia } \\
\end{array}$ & & $\begin{array}{l}\text { Participação } \\
\text { de novos } \\
\text { produtos } \\
\text { nas vendas }\end{array}$ & $\begin{array}{l}\text {-Participação } \\
\text { de novos } \\
\text { produtos nas } \\
\text { vendas }\end{array}$ & $\begin{array}{l}\text { - } \\
\text { Participação } \\
\text { de novos } \\
\text { produtos } \\
\text { nas vendas }\end{array}$ & $\begin{array}{l}\text { Participação } \\
\text { de novos } \\
\text { produtos } \\
\text { nas vendas }\end{array}$ & $\begin{array}{l}\text { Participação } \\
\text { de novos } \\
\text { produtos } \\
\text { nas vendas }\end{array}$ & \\
\hline $\begin{array}{l}\text { ALTERAÇÃO } \\
\text { NAS } \\
\text { ATIVIDADES }\end{array}$ & $\begin{array}{l}\begin{array}{l}\text { Dentro } \\
\text { da } \\
\text { cadeia }\end{array} \\
\begin{array}{l}\text { Entre } \\
\text { os elos } \\
\text { da } \\
\text { cadeia }\end{array}\end{array}$ & & & $\begin{array}{l}\text {-Divisão de } \\
\text { trabalho na } \\
\text { cadeia } \\
\text {-Funções- } \\
\text { chave } \\
\text { desenvolvidas } \\
\text { nos elos } \\
\text { individuais na } \\
\text { cadeia } \\
\\
\text {-Aumento da } \\
\text { capacitação e } \\
\text { do perfil } \\
\text { salarial }\end{array}$ & & & & \\
\hline
\end{tabular}

FONTE: AUTOR, 2008, com conceitos de KAPLINSKY; MORRIS, 2003, p. 77, aplicados aos casos estudados, classificados com base nas informações obtidas em pesquisa de campo.

Com relação à afirmação de Mytelka (2000, p. 18-19), de fato, as empresas estudadas não se encontram na fronteira tecnológica de suas respectivas atividades. O quadro 36, em seguida, traz o conceito de inovação aplicado aos casos estudados. 
Quadro 36 - Atributos da inovação que devem ser considerados em empresas de países em desenvolvimento e que podem ser encontrados nos casos estudados

\begin{tabular}{|c|c|c|c|c|c|c|c|c|}
\hline \multirow[b]{2}{*}{ ATRIBUTOS } & \multicolumn{8}{|c|}{ EMPRESA } \\
\hline & A1 & A2 & A3 & B1 & B2 & B3 & C1 & $\mathrm{C} 2$ \\
\hline Aperfeiçoamento contínuo em design de produto & & & $\mathbf{X}$ & $\mathbf{X}$ & & & & \\
\hline Aperfeiçoamento contínuo em qualidade & & & & & $\mathbf{X}$ & & & $\mathbf{X}$ \\
\hline Alterações organizacionais e nas rotinas de gestão & $\mathbf{X}$ & $\mathbf{X}$ & $\mathbf{X}$ & $\mathbf{X}$ & $\mathbf{X}$ & $\mathbf{X}$ & $\mathbf{X}$ & \\
\hline Criatividade no marketing & $\mathbf{X}$ & & & & $\mathbf{X}$ & & & \\
\hline $\begin{array}{l}\text { Modificações nos processos produtivos que reduzam } \\
\text { custos e aumentem a eficiência }\end{array}$ & $\mathbf{X}$ & & $\mathbf{X}$ & & $\mathbf{X}$ & $\mathbf{X}$ & $\mathbf{X}$ & \\
\hline
\end{tabular}

FONTE: AUTOR, 2008, com conceitos de MYTELKA, 2000, p. 18-19 aplicados aos casos estudados (informações coletadas na pesquisa de campo).

Foram considerados os aspectos mais evidentes de cada empresa. Não é possível detalhar o grau em que cada um destes atributos está presente. No caso da empresa A1 se faz referência à alteração de 1999 que modificou toda a operação para franquias de desenvolvimento e distribuição. Foi mencionada a redução de custos, embora seja avaliado que este não é o principal ganho e não foi o principal motivador da mudança. Também se faz referência ao enorme número de ações de marketing. Na empresa A2 o desenvolvimento na Argentina, Chile e México. Na empresa A3, os investimentos em design que estão sendo feitos em Taiwan, a inclusão e a ênfase na completude da automação comercial com a inclusão do software e o desenvolvimento de produto em Taiwan, mais a fabricação na China para o mercado dos EUA. Na empresa B1, a contínua busca por novos produtos sem que as alterações organizacionais decorrentes sejam interpretadas como obstáculos. A organização B2, com a atenção à gestão de pessoas, mudanças constantes na organização, ações de marketing personalizadas, medidas com precisão no caso do direcionamento às vendas e muitas vezes oportunistas; bem como a disciplina na gestão de custos (são somente três filiais em modo de início de operação simultaneamente). A empresa B3 com suas alterações constantes na estrutura e foco na gestão planejada dos processos produtivos. A empresa C1 com a mudança organizacional para unidades de negócios para que se compartilhe o que for possível e ao mesmo tempo se mantenha a individualidade das operações para retenção do capital intelectual. A empresa C2 com seu aperfeiçoamento constante na qualidade do produto em comparação com as soluções internacionais. 
Pode ser verificado que em muitos casos há uma combinação de caminhos de alto e baixo nível para a competitividade. Não se pode falar, contudo, em aperfeiçoamento limitado à esfera da produção, mesmo nos casos em que o produto é mais padronizado (empresas B2 e B3) (SCHMITZ, 1999B, p. 1627-1630). Foi freqüente a menção aos papéis que propiciam maiores recompensas (GIBBON, 2003, p. 21). Contudo, em nenhum caso foi constatada a orientação total ou majoritariamente para exportação. Todas as empresas começaram em virtude da existência do mercado interno brasileiro, classificado por muitos entrevistados como sofisticado (HUMPHREY, 2003, p. vii).

Com relação à presença de bloqueadores e impulsionadores do aperfeiçoamento competitivo, pode ser mencionada a presença de alguns dos exemplos de Kaplinsky e Morris (2003, p. 78):

\section{Bloqueadores}

- $\quad$ Quanto à resistência dos níveis gerenciais, na empresa B3, onde têm ocorrido revisões constantes da estrutura isto não tem ocorrido. O comentário é que os executivos já se habituaram às mudanças constantes.

- $\quad$ No tocante à falta de capacitação, uma evidência de que pode existir no setor de TI no Brasil é a criação da universidade para capacitação de funcionários da empresa e parceiros na empresa A3.

- $\quad$ Outro inibidor mencionado, neste caso fora da empresa é o fato do Brasil não ser signatário de acordos internacionais relacionados à propriedade intelectual.

\section{Impulsionadores}

- $\quad$ Em especial na empresa B1 se destaca esta questão dos processos estruturados para o desenvolvimento permanente.

- $\quad$ Em termos dos fatores fora da empresa, o custo da mão-de-obra tem aumentado e se encontra em níveis altos, conforme foi observado por vários entrevistados.

- $\quad$ Também fora da empresa, a concorrência tem aumentado no mercado brasileiro com o ingresso de empresas estrangeiras, especialmente indianas (menção pela empresa B3).

O aumento do custo da mão-de-obra funciona como impulsionador, à medida que incentiva o desenvolvimento de produtos mais sofisticados pelas empresas e as pressiona a buscar atividades que possibilitem maiores rendas. 
Em especial nas empresas B2, B3 e C1 foi notado bastante foco na competitividade através de preço. Nos casos B2 e B3, há também ênfase no aperfeiçoamento competitivo do processo produtivo. A questão do conflito de interesses só foi mencionada pela empresa B1. Neste caso, diferente do que menciona Schmitz (1999B, p. 1647-48), a empresa de fora não é compradora, mas a organizadora da cadeia da qual a estudada participa. Esta questão do bloqueio do aprendizado em momentos posteriores já aconteceu em outra situação no caso da B1, também pela líder organizadora da fora, de origem norte-americana. Com relação à concentração do segmento comprador - o que seria um facilitador ao bloqueio para migração a novas funções - este fenômeno pode ser observado no caso das empresas A1, B1, B2, B3, C1 e C2. A empresa C2 no produto gestão eletrônica de documentos tem possibilidade de desconcentrar a base compradora, mas há suspeita que sua base de clientes coincida em grande parte com a do outro produto, voltado para atividade especializada do segmento financeiro. De fato, no caso em que ocorreu aperfeiçoamento funcional, a base de compradores é fragmentada, composta por pequenas empresas, principalmente. Foi divulgado na imprensa que esta empresa teve problemas de entrega ao se envolver com grandes empresas com um de seus produtos.

Diferente do que notaram Bazan e Navas-Alemán (2001, p. 64-65), a questão da discrição no aperfeiçoamento competitivo não foi verificada. As empresas estudadas procuram ativamente a diversificação de mercados. A empresa que participa de várias cadeias é a A3 e neste caso há diferença de trajetória nas cadeias. Na cadeia do hardware a empresa está mais evoluída do que na do software. Esta questão é reconhecida como um desafio a enfrentar, inclusive no contexto internacional. Foi notada em todos os casos forte intenção de aprender com estrangeiros, portanto, diferente do que foi concluído por Schmitz e Knorringa (1999, p. 14). O que varia entre as empresas estudadas é o nível de aprendizado: há casos de enorme avanço e aqueles que ainda se encontram nas fases iniciais do processo, como pode ser compreendido com maior clareza através do exame do quadro 37, apresentado em seguida. 
Quadro 37 - Nível de aprendizado dos casos estudados com empresas internacionais

\begin{tabular}{|c|c|c|}
\hline CASO & $\begin{array}{l}\text { NÍVEL DO } \\
\text { APRENDIZADO }\end{array}$ & $\begin{array}{l}\text { SITUAÇÃO } \\
\text { INTERNACIONAL }\end{array}$ \\
\hline A1 & Alto & $\begin{array}{l}\text { - Distribuição no México. Estudada abriu franquia de } \\
\text { distribuição para criar interesse pelo negócio. }\end{array}$ \\
\hline A2 & Alto & $\begin{array}{l}\text { - Possibilidade de transferir desenvolvimento para o exterior. } \\
\text { - Aprendizado no México que pode ser utilizado em outros } \\
\text { países em desenvolvimento. }\end{array}$ \\
\hline A3 & Alto & $\begin{array}{l}\text { - Tecnologia na Europa } \\
\text { - Desenvolvimento de produtos em Taiwan } \\
\text { - Fabricação na China } \\
\text { - Novos esquemas de distribuição nos EUA }\end{array}$ \\
\hline B1 & Alto & $\begin{array}{l}\text { - Constatação de fragilidade no relacionamento com o } \\
\text { exterior. Necessidade de preparar o próximo passo. }\end{array}$ \\
\hline B2 & Alto & $\begin{array}{c}\text { - Bancos que são clientes no México } \\
\text { - Como desenvolver programas de comunicação com o } \\
\text { mercado em outros países }\end{array}$ \\
\hline B3 & Em evolução & $\begin{array}{c}\text { - Desenvolveu estratégia para atuação no mercado europeu } \\
\text { em conjunto com empresa local }\end{array}$ \\
\hline C1 & Alto & $\begin{array}{l}\text { - Necessidade de alinhamento com o comprador no exterior } \\
\text { para a contratação de parceiros de implantação }\end{array}$ \\
\hline C2 & Alto & $\begin{array}{l}\text { - Empresa líder da cadeia (fabricante de equipamentos) tem } \\
\text { dado apoio e orientação para atuação da estudada. } \\
\text { - Aprendizado com compradores possibilitou aperfeiçoamento } \\
\text { de produto. }\end{array}$ \\
\hline
\end{tabular}

FONTE: AUTOR, 2008, com informações da pesquisa de campo e conceitos de SCHMITZ; KNORRINGA, 1999, p. 14.

Da mesma forma ao que apontam Dedrick e Kraemer (1998, p. 7) sobre o setor de informática na Ásia, dentre as empresas estudadas também ocorre evolução sem dar importância às fronteiras nacionais. O caso mais evoluído nesta direção é o da empresa A3. Este fato configuraria a divergência entre competitividade nacional e empresarial.

A expansão externa do setor de TI brasileiro ocorre a despeito de ser fragmentado. Embora não sejam apresentados indicadores desta fragmentação, este ponto foi mencionado várias vezes na pesquisa de campo. Contudo, também foi mencionado que a necessidade de escala é algo importante e que tem crescido em relevância. A expansão externa foi algo notado como importante por todos os entrevistados. Só não existe investimento direto estrangeiro (IDE) nos 
casos das empresas B3, C1 e C2. No caso da empresa B1, já existiu IDE no passado e foi afirmado pelo entrevistado que é a empresa partirá para atuação direta na América Latina nos próximos meses, fato que foi confirmado no primeiro quadrimestre de 2008 por notícias publicadas na imprensa. A empresa B1 exporta serviços a partir do Brasil, operação que se encontra em fase de desativação. Portanto, o resultado de Basile et al (2004, p. 84-86 e 101) não é confirmado nos casos estudados. Contudo, quanto à complementaridade em termos de inovação e competitividade em preço, os resultados se confirmam. No entanto, é necessário qualificar que nos casos estudados não se está a falar de inovação tecnológica, mas de outras formas de inovação.

Quanto às considerações de Castellani (2004, p. 125-126) sobre a intensidade exportadora, não se pode mencionar que este fenômeno exista entre as estudadas. Ainda assim, em todos os casos eficiência e produtividade apareceram entre as preocupações, com especial ênfase nos casos B2 e B3. Com relação à estrutura interna para processamento e utilização das informações a que se teve acesso nos mercados internacionais, segue no quadro 38 um resumo do que existe nas estudadas. 


\begin{tabular}{|c|c|}
\hline EMPRESA & ESTRUTURA PARA ATUAÇÃO INTERNACIONAL \\
\hline A1 & Diretoria de Operações para a América do Sul, foco da expansão internacional no momento. \\
\hline A2 & $\begin{array}{l}\text { Diretoria de Expansão Internacional. Na Europa possui escritório próprio com Diretor baseado e } \\
\text { mais de } 20 \text { colaboradores, responsável também pela atuação em parte do continente africano. }\end{array}$ \\
\hline A3 & $\begin{array}{l}\text { Diretoria para América Latina, Europa e Ásia, baseada em São Paulo. Executivo principal chega } \\
\text { a passar três semanas por mês fora do Brasil cuidando da expansão. }\end{array}$ \\
\hline B1 & $\begin{array}{l}\text { Embora não tenha diretoria de expansão internacional, foram obtidas evidências de que existe } \\
\text { um trabalho de inteligência de mercado para examinar, principalmente, os mercados da América } \\
\text { Latina. }\end{array}$ \\
\hline B2 & $\begin{array}{l}\text { Membros do Conselho de Administração com larga experiência em internacionalização. Tem } \\
\text { responsáveis de alto nível nas regiões e países em que atua. Vice-Presidência responsável pelos } \\
\text { mercados externos. Há executivos especializados na implantação de unidades em outros países. } \\
\text { Para prospecção de clientes no exterior, considera o peso que o Brasil tem nas suas operações } \\
\text { globais. }\end{array}$ \\
\hline B3 & $\begin{array}{c}\text { Executivo europeu é responsável pela atividade comercial no exterior. Contratação de parceiros } \\
\text { no exterior, para entre outras atividades, apoiar a empresa no conhecimento das regiões que } \\
\text { deseja atuar. }\end{array}$ \\
\hline C1 & $\begin{array}{c}\text { O diretor da unidade de negócio com maior sucesso no exterior é o responsável pela atividade } \\
\text { internacional. }\end{array}$ \\
\hline C2 & $\begin{array}{l}\text { O gestor de negócios da empresa é responsável pela atuação internacional, a qual dedica boa } \\
\text { parte do seu tempo. Conta no exterior com o apoio da empresa líder da cadeia, fabricante de } \\
\text { equipamentos para obtenção de informações. }\end{array}$ \\
\hline
\end{tabular}

FONTE: AUTOR, 2008, com informações obtidas na pesquisa de campo e disponibilizadas publicamente pelas empresas estudadas.

Embora a existência da estrutura não garanta a eficácia na coleta, processamento e desenvolvimento obtido internacionalmente, significa que as empresas estudadas priorizam a atuação internacional. Um outro fato é que três das estudadas são de capital aberto e nas informações disponibilizadas por estas empresas, o foco na internacionalização aparece em destaque. Há menção de internacionalização nas outras três empresas da amostra que se preparam para abrir o capital. A empresa A3 se destaca na estrutura de obtenção das informações e conhecimento obtido internacionalmente, pois mantém estruturas próprias principalmente para este fim na Ásia e na Europa. Nas entrevistas realizadas, foi revelado que já houve questionamentos internos sobre a conveniência de se manter estas estruturas e que levou tempo para que todos se convencessem de sua validade. 
Com a classificação de Humphrey et al (1998, p. 251-252) sobre os concorrentes das empresas dos países em desenvolvimento, foi constatado que:

- $\quad$ As empresas B2 e B3 têm como principais competidores as empresas da Índia, ou seja, do primeiro grupo mencionado. Estas empresas têm como vantagem competitiva os custos baixos. Contudo, alguns comentários cabem sobre isto. Alguns entrevistados questionaram a vantagem de custo dos indianos, pois o negócio, mesmo na sua atividade técnica, não é só escrever linhas de código. Os indianos perdem competitividade por raramente terem situações de uso com os produtos que desenvolvem, por exemplo, para o setor financeiro. Esta é uma vantagem dos brasileiros, que lhes possibilita maior resolutividade, o que significa trabalho com menos supervisão e menos erros, portanto com menores custos nestes aspectos. Outro comentário é que foi verificado que algumas das empresas da amostra têm se aproveitado e desenvolvido código na Índia, ficando com as atividades mais sofisticadas da cadeia de valor. Outra consideração é que há empresas brasileiras, por exemplo, a A1, A2, A3 e B3, que pode ser incluído no grupo das empresas que obtiveram êxito como competidoras dos países em desenvolvimento. O caso A2 é emblemático deste fenômeno: a empresa divulga e apresenta dados que comprovam que é a maior do mundo na sua atividade, originária de mercados emergentes. Provavelmente, há outra empresa brasileira da amostra entre as cinco ou seis maiores do mundo na atividade. Com relação à recomendação às empresas indianas, os resultados obtidos indicam que as estudadas brasileiras já estão aplicando novas formas organizacionais, agora devem buscar sustentar o processo de forma a ampliar as inovações organizacionais.

- $\quad$ Existe um segundo grupo de empresas concorrentes que vêm dos países desenvolvidos. Embora estas empresas não tenham sido examinadas de perto, de acordo com a lista citada pelos entrevistados e pesquisas em fontes secundárias, muitas destas organizações competem na base da escala e do amplo escopo de produtos e serviços. É possível e até provável que operem com qualidade, mas pelas informações obtidas não descartam o fornecimento em países em desenvolvimento, como, por exemplo, a Índia.

Com relação à competição em preço, o quadro 39, que segue, traz uma breve apresentação da situação encontrada junto aos casos estudados. 


\begin{tabular}{l}
$\begin{array}{c}\text { Quadro } 39 \text { - Abordagem das empresas estudadas quanto a competir através do fator } \\
\text { preço }\end{array}$ \\
\begin{tabular}{|c|c|}
\hline EMPRESA & COMPETIÇÃo ATRAVÉS DO FATOR PREÇO \\
\hline A1 & $\begin{array}{c}\text { Compete principalmente através da flexibilidade do sistema e do comportamento empreendedor } \\
\text { de suas franquias de desenvolvimento e distribuição. Outra vantagem competitiva é a rapidez } \\
\text { para desenvolver e implementar novas versões. Procura atuar onde é necessário inteligência, } \\
\text { devido às atividades serem mais complexas. Preço não é a principal arma competitiva. }\end{array}$ \\
\hline A2 & $\begin{array}{c}\text { Compete no segmento das PMEs no qual grandes concorrentes não estão suficientemente } \\
\text { capacitados para atuar. Seus sistemas são desenvolvidos para funcionar sem problemas no } \\
\text { contexto das PMEs. Foco não é preço. }\end{array}$ \\
\hline A3 & $\begin{array}{c}\text { Compete com base na completude da solução e na confiabilidade das soluções. Foi declarado que } \\
\text { a organização cobra preços premium, portanto não compete em preço. }\end{array}$ \\
\hline B1 & $\begin{array}{c}\text { Não compete em preço. Uma evidência é o encerramento da operação nos EUA (prestação de } \\
\text { serviços). A empresa nem considerou a movimentação para locais de custos mais baixos. }\end{array}$ \\
\hline B2 & $\begin{array}{c}\text { Compete com foco em produtividade, custo e preço. Evidentemente não são as únicas armas } \\
\text { competitivas, mas provavelmente são as principais. }\end{array}$ \\
\hline B3 & $\begin{array}{c}\text { Compete com base na produtividade e eficiência, obtidos através de planejamento detalhado das } \\
\text { operações. Foco em preço. Contudo, tem procurado se afastar dos produtos padronizados, nos } \\
\text { quais a competição de preço é maior. }\end{array}$ \\
\hline C1 & $\begin{array}{c}\text { Competição através da completude da solução para um segmento específico, o financeiro. } \\
\text { Procura aumento de produtividade através de economias de escopo e também de escala. } \\
\text { Estratégia competitiva não é preço, mas diferenciação. }\end{array}$ \\
\hline Foi declarado que tem custos mais baixos e, portanto, pratica preços mais baixos. Portanto, \\
embora atue voltado para um segmento, pelas declarações, compete em preço.
\end{tabular} \\
\hline
\end{tabular}

FONTE: AUTOR, 2008, com informações obtidas na pesquisa de campo e disponibilizadas publicamente pelas empresas estudadas.

Portanto, das informações apresentadas no quadro 39, verifica-se que somente as empresas B2, B3 e C3 declaram que o preço é um fator competitivo importante. Os entrevistados na empresa B3 explicaram que procuram se afastar da competição em preço, mas que em algumas situações não é possível. A empresa B2 colocou ênfase no fator flexibilidade e também no treinamento da mão-de-obra, que é a origem da empresa. A empresa C2 que foi uma surpresa, pois seu foco em preço foi acima do esperado. Em virtude de atuar com um produto diferenciado e com enfoque em um segmento de mercado, talvez não fosse necessária uma ênfase tão grande no fator preço para competir.

Para utilizar as recomendações quanto à medição da competitividade propostas por Dedrick e Kraemer (1998, p. 14-15), conforme as respostas obtidas dos entrevistados na pesquisa de campo, tecnologia e, portanto, liderança tecnológica não são fatores fundamentais nas 
atividades desenvolvidas. Com relação ao crescimento, a tabela 5, que segue, apresenta informações sobre o crescimento da receita bruta (estimado ou divulgado) das empresas estudadas.

Contudo, este indicador, embora de fácil medição, não é confiável. Primeiro porque o mercado de TI está ativo em fusões e aquisições, o que pode levar a distorções nestes indicadores, também quando avaliados comparativamente. Segundo, por informações obtidas nas entrevistas, validadas por informações coletadas em fontes secundárias, o mercado de TI nos países em desenvolvimento e também no Brasil, crescem a uma taxa superior aos países desenvolvidos, que por sua representatividade influenciam a média mundial (IDC, 2008).

Tabela 5 - Receitas brutas das organizações estudadas - Percentuais de crescimento do ano 2007 comparado com 2006

\begin{tabular}{|c|c|}
\hline EMPRESA & $\begin{array}{c}\text { CRESCIMENTO DA RECEITA BRUTA } \\
\text { EM RELAÇÃO AO ANO ANTERIOR } \\
\text { (\%) }\end{array}$ \\
\hline A1 & +27 \\
\hline A2 & +17 \\
\hline A3 & +21 \\
\hline B1 & +33 \\
\hline B2 & +15 \\
\hline B3 & +40 \\
\hline C1 & $+35 \mathrm{a}+75$ \\
\hline C2 & +15 \\
\hline BRASIL & $+\mathbf{1 2}$ \\
\hline (MOVIMENTAÇA & \\
\hline FINANCEIRAEM TI) & \\
\hline
\end{tabular}

FONTE: AUTOR, 2008, com informações obtidas na pesquisa de campo, disponibilizadas publicamente pelas empresas estudadas e IDC, 2008.

Como pode ser observado na tabela 5 , todas as empresas estudadas cujos números de crescimento foram disponibilizados, obtiveram taxas superiores à média brasileira, que é o dobro da média mundial. Portanto, de acordo com o que propõem Dedrick e Kraemer (1998, p. 14-15), este seria um indicador da competitividade, pois garante que existam investidores dispostos a financiar a expansão. De fato, é o que se tem verificado, embora notícia recente 
sobre o desempenho da organização A3 informe que houve uma debandada de investidores estrangeiros do seu capital nos últimos meses, a exemplo do que ocorreu com outras empresas de porte similar de capital aberto.

Com relação à eficácia com quem chegam aos mercados externos, todas as empresas tem acessado o exterior. Também, todas informam que possuem planos para aumentar a participação das vendas de fora no seu faturamento total. Se estes planos realmente se concretizarem, estas empresas poderão manter as altas taxas de crescimento observadas e alcançar níveis de vendas suficientemente altos para amortizar custos operacionais, administrativos e de desenvolvimento de produtos. Aliás, na pesquisa de campo, a menção à necessidade de escala na atividade pelos executivos entrevistados foi freqüente.

Quanto às formas de competir, apontadas por Kogut (1985, p. 31-33), foi realizada uma classificação dos casos estudados (QUADRO 40):

Quadro 40 - Classificação dos casos estudados quanto à forma de competir

\begin{tabular}{|c|c|c|c|c|c|c|c|c|}
\hline \multirow[b]{2}{*}{ FORMAS DE COMPETIR } & \multicolumn{8}{|c|}{ EMPRESA } \\
\hline & A1 & A2 & A3 & B1 & $\mathbf{B 2}$ & B3 & C1 & $\mathrm{C} 2$ \\
\hline $\begin{array}{l}\text { Competição baseada na vantagem comparativa de um } \\
\text { país }\end{array}$ & & & & & $\mathbf{X}$ & $\mathbf{X}$ & & \\
\hline $\begin{array}{l}\text { Competição baseada nas vantagens competitivas das } \\
\text { empresas (fluxos cruzados de comércio de produtos } \\
\text { similares e IDE) }\end{array}$ & & & & & $\mathbf{X}$ & $\mathbf{X}$ & & \\
\hline $\begin{array}{l}\text { Interação entre vantagem competitiva e vantagem } \\
\text { comparativa }\end{array}$ & $\mathbf{X}$ & $\mathbf{X}$ & $\mathbf{X}$ & $\mathbf{X}$ & & & $\mathbf{X}$ & $\mathbf{X}$ \\
\hline
\end{tabular}

FONTE: AUTOR, 2008, com conceitos de KOGUT, 1985, p. 31-33, aplicados aos casos estudados (informações coletadas na pesquisa de campo).

As empresas B2 e B3 são casos de exportação de produtos padronizados, ou próximos a isto, portanto classificadas como competição através da vantagem comparativa. A empresa B3 procura a competição através de produtos mais sofisticados, procurando se afastar dos padronizados, o que lhe vale a classificação também na competição baseada nas vantagens competitivas das empresas. Na B2 e na B3 ocorre o IDE para penetração de mercados. Contudo, a maior parte dos casos pode ser classificada na terceira forma de competir: interação entre vantagem competitiva e vantagem comparativa. Os casos das empresas A3 e B1 podem ser expostos de forma clara: as duas estão competindo com base na superioridade 
em termos de configuração das fontes de fornecimento. No caso da empresa B1, parte de suas fontes superiores de fornecimento estão em outros países, Taiwan e China. No caso da empresa A1, é mais complexo, existe uma vantagem de mão-de-obra qualificada no Brasil e a empresa aderiu a um ecossistema mundial da sua atividade para prestar serviços em parceria com uma empresa de um país desenvolvido na América Latina (decisão produt0-mercado). Também se pode falar em decisão produto-mercado nas empresas A2, C1 e C2. No caso das empresas C1 e C2, existe uma combinação da vantagem existente no Brasil de um mercado financeiro sofisticado com o desenvolvimento de produtos para missões críticas nesta atividade. Na empresa A1, bem como na A2, se pode falar em investimentos horizontais, pois as empresas no exterior, em muitos dos países replicam a cadeia de valor do Brasil. Pode-se falar em padrão complexo de dispersão, pois algumas destas empresas, a C1 é um exemplo, além de terem produtos exportados, mantêm parcerias com empresas de fora para implantação no Brasil.

Pelo crescimento verificado das empresas (TABELA 5), se pode falar em aumento das economias de escala em função de um mercado maior. Também, pelas demais informações apresentadas neste estudo, pode ser indicado o aumento das economias de escopo e maior experiência. O caso das economias de escopo é verificado nas empresas A1 e A2, com as compras, na A3 com a completude da oferta, B3 com o envolvimento com produtos mais sofisticados, C1 com a compra de empresas e conseqüente incorporação de novos produtos ao seu portfólio, e A1, A2, A3, B1, B2, C1 e C2 com maior experiência, resultante de conhecimento adquirido com oportunidades de marketing.

Com relação à estratégia, competitividade e estrutura, conforme proposto por Rugman e D’Cruz (2000, p. 81), das empresas estudadas, são notáveis os casos das empresas A1 e B1. A que mais se aproxima da relação empresarial do tipo rede é a B1, embora não seja a líder da cadeia da qual participa. No caso A1, a empresa é líder e além de governar, modelou e implementou a cadeia, na qual pode ser verificada intensa cooperação. Os gestores no caso A1 pensaram na competitividade ao estimular o comportamento empreendedor na cadeia.

Quanto à classificação proposta por Wortzel e Wortzel (1981, p. 51), segue, de forma resumida, a apresentação dos estágios pelos quais as empresas passaram e podem ser classificadas hoje: 
- A1. Estágio I, pois conta com clientes no Canadá, Europa, Turquia e Rússia, para citar alguns países, contudo foi declarado que este tipo de operação é diferente da internacionalização consistente e pró ativa que a empresa passou a fazer. Nestes casos, a empresa passou de dependência passiva da ação importadora para a busca ativa de uma estratégia, chamada de ação exportadora. A empresa hoje pode ser classificada no Estágio V, em virtude da localização em outros países e comercialização de suas próprias marcas.

- $\quad$ A2. A empresa já passou do Estágio IV, pois foi enfatizado o investimento em recursos humanos e também comercializa suas próprias marcas. Hoje pouco apoio por parte dos compradores para especificações. Na atualidade a empresa pode ser classificada no Estágio V, também pela localização em outros países. Contudo, há mais fatores, que justificam a classificação neste estágio. As organizações nos mercados externos ficaram mais sofisticadas, por exemplo, México, Argentina e Chile, onde se realiza desenvolvimento.

- A3. A empresa seleciona os distribuidores, ao invés de ser selecionada por eles, como ocorre no Estágio I. A empresa não só desenvolveu capacitação interna em termos de desenvolvimento, como terceirizou o desenvolvimento de produto na Ásia. Também pode ser classificada no Estágio V, pela localização em outros países. As organizações no exterior estão crescendo, embora na Ásia e nos EUA não possam ser consideradas pequenas, também em termos de complexidade operacional.

- $\quad$ B1. A empresa já passou por várias fases e por razões diferentes desativou ou vendeu as operações. Há um longo histórico de atuação internacional, na maior parte das vezes bem sucedida. A empresa busca as oportunidades no exterior de forma pró ativa. É especializada em poucos produtos. Os investimentos da empresa em recursos humanos são altos. Pessoal muito especializado. Contudo, não comercializa suas próprias marcas, mas as da empresa líder (característica do Estágio IV). Também pode ser classificada no Estágio V pela localização em outros países. Trata-se de uma necessidade: é preciso ter bases operacionais locais nos outros países.

- $\quad$ B2. A empresa também já não desempenha um papel passivo na atuação internacional. Portanto, já não pode ser classificada no estágio I. Embora tenha produtos consolidados e que possuem características associadas à padronização, ainda necessita de apoio dos compradores para as especificações, que é uma característica, no mínimo, de uma empresa que se encontra no Estágio II. Pode ser que este aspecto esteja relacionado à proposta da empresa de flexibilidade. O investimento em recursos humanos, de acordo com as declarações obtidas, as evidências e o histórico da empresa, é alto. Esta é uma característica do Estágio IV. Quanto à 
comercialização de suas próprias marcas, que é uma outra característica do Estágio IV, a empresa só presta serviços com produtos de terceiros. A marca em evidência é a do terceiro estágio e não a do caso B2. Uma outra característica do Estágio IV é a habilidade em marketing, definitivamente presente nesta organização no que concerne sua atuação internacional. Segundo as informações obtidas, esta empresa opera com organizações maiores e mais sofisticadas nos mercados externos, ainda que isto possa variar dependendo do mercado. Por esta última razão, em conjunto com as demais mencionadas, este caso também pode ser classificado no Estágio $\mathbf{V}$.

- $\quad$ B3. Esta organização já passou do Estágio I, no qual ainda se está passivamente à espera de um importador. Suas ações nos EUA e na Europa, evidenciam a busca ativa de uma estratégia que é chamada de ação exportadora. De novo, embora tenha produtos que possuam características associadas à padronização, também necessita de apoio dos compradores para as especificações, que é uma característica, no mínimo, de uma organização que já alcançou o Estágio II. Aqui, segundo as afirmações que foram feitas pelos entrevistados, se procura planejar com antecedência para conferir maior eficiência à operação. A empresa conta com capacitação interna em termos de desenvolvimento, como evidencia a inauguração recente de fábrica de software. A empresa tem procurado aumentar sua linha para se afastar dos produtos padronizados, de baixa complexidade, que são de renda mais baixa. Portanto, uma vez que há esta opção e ela tem sido exercida de forma planejada, se pode falar, no mínimo, em Estágio III. Foi notada uma ênfase na atividade de gestão de pessoas. Se for pela localização em outros países, pode ser afirmado que a empresa ainda não chegou ao Estágio V. Pelas declarações obtidas, há consciência de que este é um passo que está sendo considerado com cuidado. Dado os comentários que foram feitos sobre a atuação das concorrentes originárias da Índia no mercado brasileiro, pode ser que a empresa seja obrigada a realizar esta movimentação para defender sua posição atual no mercado brasileiro. Outro aspecto que foi mencionado é a necessidade de atuar com certos produtos de baixa renda para estar habilitada a prestar serviços que possibilitam renda mais alta. Portanto, em função de todos estes fatores, esta empresa pode ser classificada no Estágio III.

- $\quad$ C1. Esta empresa fez sua opção por exportações recentemente. Na verdade, no momento das entrevistas, somente uma das unidades de negócios da empresa mantinha operações comerciais regulares com o exterior. A empresa definitivamente possui capacitação interna de desenvolvimento, o que é uma característica do Estágio II. A empresa está aumentando a sua linha de produtos, mas sempre com foco no mercado financeiro. Esta ação é fruto de uma escolha, o que é uma característica do Estágio III. Não se pode falar em 
Estágio IV, pois não há localização em outros países, somente exportação. Esta empresa pode ser classificada no Estágio III, naquela situação em que se está próximo da decisão de ir para o Estágio IV.

- $\quad$ C2. A empresa fez sua opção por exportações, portanto já não está mais no Estágio I. A organização possui capacitação interna de desenvolvimento. A empresa é especializada em poucos produtos, o que por si não é um problema. Contudo, parece que esta não é uma situação deliberada, mas uma situação que está posta. Portanto, por esta característica, esta organização estaria no Estágio II. A empresa comercializa suas próprias marcas, o que é uma característica do Estágio IV. No entanto, a empresa ainda não chegou neste estágio, mas pode estar caminhando na direção de ter que fazer uma opção. De acordo com as declarações obtidas, a empresa é internacionalmente competitiva em preço, o que é uma característica pelo menos do Estágio II. Esta empresa pode ser classificada no Estágio III, nas suas fases iniciais.

É apresentado a seguir (QUADRO 41) um resumo da classificação das organizações estudadas, de acordo com os estágios propostos por Wortzel e Wortzel (1981, p. 51).

Quadro 41 - Classificação dos casos estudados quanto à exportação

\begin{tabular}{|c|c|}
\hline EMPRESA & ESTÁGIO \\
\hline A1 & V \\
\hline A2 & V \\
\hline A3 & V \\
\hline B1 & V \\
\hline B2 & V \\
\hline B3 & III \\
\hline C1 & III \\
\hline C2 & III \\
\hline
\end{tabular}

FONTE: AUTOR, 2008, com conceitos de WORTZEL; WORTZEL, 1981, p. 51, aplicados aos casos estudados (informações obtidas na pesquisa de campo).

Como Kogut (1985, p. 11-13) argumenta em termos das vantagens competitivas que podem ser transferidas globalmente, segue exame das empresas estudadas quanto a este aspecto: 
- $\quad$ No caso A1, uma vantagem que parece estar sendo transferida globalmente são aquelas conseqüentes do modelo de franquias de desenvolvimento e distribuição que foram implementados pela empresa a partir de 1999. Nesta situação, se pode falar em aprendizado. Neste caso, pelo menos localmente não se pode falar em desvantagem quanto à localização: no Brasil, a região Sul do Brasil é um pólo de TI. Os entrevistados, em todos os casos estudados que têm origem ou operam nesta região, unanimemente, mencionaram a abundância de mão-de-obra qualificada. No caso A1, em termos regionais, também não se pode falar em desvantagem, pois há proximidade geográfica e cultural dos maiores mercados da América do Sul. Também se pode falar em vantagem competitiva criada a partir de economias de escopo, pois esta organização estudada tem desenvolvido outros produtos softwares e serviços - como HCM (Human Capital Management), BI (Business Intelligence), ECM (Enterprise Content Management), B2B (Business to Business), CRM (Customer Relationship Management). Contudo, não se pode falar em vantagem competitiva a partir de economias de escala, pois o porte desta organização é bem menor do que o porte do que os seus concorrentes internacionais no segmento-alvo.

- $\quad$ No tocante ao caso A2, sua vantagem competitiva advém do aprendizado de atuar no segmento das PMEs. Também se pode mencionar vantagem competitiva obtida através de economias de escopo, pois tem desenvolvido ou comprado empresas que desenvolveram soluções verticais para atuação em conjunto com seu produto original, os sistemas chamados de ERPs. Com relação à vantagem competitiva obtida com economias de escala, no segmento escolhido, seu porte é considerável. Mais do que isto, em termos regionais a empresa se declara a maior empresa dos mercados emergentes do mundo na sua atividade. Portanto, no segmento e em termos geográficos, neste caso, possivelmente se pode falar em vantagem competitiva obtida através do porte.

- $\quad$ No caso A3, a vantagem competitiva obtida através do aprendizado na atividade de automação comercial é bem clara. Também se pode falar em economia de escala, pois no mercado nacional, a empresa declara participação de mercado em determinado produto acima de 60\%. A empresa também desenvolveu vantagem competitiva a partir de economia de escopo com o produto software.

- $\quad$ A empresa B1 obteve vantagem competitiva a partir do aprendizado. Este aprendizado é, não só, técnico e tecnológico, relacionado à integração de sistemas em telecomunicações, mas também relacionado à atuação nos mercados externos, em especial nos países em desenvolvimento. 
- $\quad$ A empresa B2 adquiriu vantagem competitiva a partir do aprendizado, neste caso de atuação nos mercados externos, desenvolvidos e em desenvolvimento. Também se pode falar em vantagem competitiva a partir de economias de escopo, pois além de ter continuadamente complementado sua oferta com novos produtos, atua com base em alianças com organizações que complementem sua atuação. De maneira menos enfática se pode falar em vantagem competitiva obtida a partir de economias de escala. O argumento para este último ponto é singelo: em mercados competitivos, com produtos tendendo à padronização, como é o foco da empresa, seria impossível competir sem um nível razoável de vantagem competitiva a partir de economias de escala.

- $\quad$ A empresa B3 obtém vantagem competitiva principalmente a partir de economias de escala. Seu porte para o mercado brasileiro é notável. Também se pode falar em menor grau em economia de escopo, pois a empresa tem incorporado novos produtos com freqüência como declararam os entrevistados e tem sido confirmado pelas notícias publicadas pela imprensa sobre a atuação desta organização. Em menor grau se pode falar em aprendizado, neste caso relacionado à freqüente incorporação de novas empresas, novas produtos e conseqüentes adaptações na estrutura.

- $\quad$ A empresa $\mathbf{C 1}$ obtém vantagem competitiva principalmente do aprendizado. Aqui a referência é em relação ao aprendizado de atuar em um segmento específico do mercado - o financeiro - com diversos produtos. Portanto, se pode falar em economias de escopo, embora em uma dimensão diferente das outras empresas, pois esta organização está focada no segmento financeiro, para o qual estão direcionados todos os seus produtos. É possível falar em vantagem competitiva a partir da escala se este caso for comparado com empresas menores de TI, que atuam com um produto voltado para o mercado financeiro.

- $\quad$ A empresa $\mathbf{C 2}$ obtém sua vantagem competitiva do aprendizado. Aqui se pode falar em aprendizado em termos técnicos e tecnológicos. Contudo, também cabe mencionar o aprendizado de atuação global em uma cadeia liderada por uma enorme multinacional do setor.

O quadro 42, que segue, traz um resumo de onde provêm as vantagens competitivas dos casos estudados. 
Quadro 42 - Origem da vantagem competitiva dos casos estudados

\begin{tabular}{|c|c|c|c|}
\hline EMPRESA & $\begin{array}{c}\text { ECONOMIAS } \\
\text { DE ESCALA }\end{array}$ & $\begin{array}{c}\text { ECONOMIAS } \\
\text { DE ESCOPO }\end{array}$ & $\begin{array}{c}\text { ECONOMIAS } \\
\text { DE APRENDIZADO }\end{array}$ \\
\hline A1 & $\mathbf{X}$ & $\mathbf{X}$ & $\mathbf{X}$ \\
\hline A2 & $\mathbf{X}$ & $\mathbf{X}$ & $\mathbf{X}$ \\
\hline A3 & $\mathbf{X}$ & $\mathbf{X}$ & $\mathbf{X}$ \\
\hline B1 & $\mathbf{X}$ & $\mathbf{X}$ & $\mathbf{X}$ \\
\hline B2 & $\mathbf{X}$ & $\mathbf{X}$ & $\mathbf{X}$ \\
\hline B3 & $\mathbf{X}$ & (menos ênfase)
\end{tabular}

FONTE: AUTOR, 2008, com conceitos de KOGUT, 1985, p. 11-13, aplicados aos casos estudados (informações obtidas na pesquisa de campo e também em fontes secundárias)

As empresas estudadas, pelas informações obtidas, têm reforçado suas vantagens competitivas e também procurado obter outras. As atividades das empresas B2 e B3 são aquelas com menor diferenciação na oferta em comparação com as empresas estudadas. A empresa B2 tem investido em investimento nas instalações no exterior. De alguma forma, estas empresas através de associação criada têm procurado influenciar o governo, não no sentido de protegêlas como indica Kogut (1985, p. 11-13), mas no sentido de possibilitar condições menos desiguais de competição com empresas de outros países em desenvolvimento, notadamente a Índia. As demais empresas da amostra, por terem maior capacidade de utilizar conhecimento, como indicam Cassiolato e Lastres (2000, p. 33), estão mais bem posicionadas para a competitividade sustentável e para o crescimento. No entanto, de acordo com as informações obtidas na pesquisa de campo, os próprios entrevistados declararam que suas empresas ainda não chegaram ao nível de gerar conhecimento, outra capacitação importante para a competitividade sustentável e para o crescimento.

Com relação ao que indica Humphrey (2003, p. 18-19) em relação ao travamento em GVCs caracterizadas por relações quasi-hierárquicas, na seqüência são examinados os casos estudados. 
- $\quad$ As organizações A1 e A2 são líderes de suas cadeias e têm evoluído suas respectivas ofertas de produto, portanto não se enquadram ao que sugere Humphrey (2003, p. 18-19). A organização A2, em especial, pois obtém sua receita de forma mais pulverizada do que a A1, pois direciona sua atuação para as PMEs.

- $\quad$ A organização A3, além voltar sua ação para as PMEs, é o único caso da amostra no qual houve aperfeiçoamento funcional recente. Portanto, não se pode falar em travamento na posição, como preconizado por Humphrey (2003, p. 18-19). Outro fator que a distancia desta situação de travamento é a sua condição de líder da cadeia. Inclusive, esta empresa tem se afastado de suas atividades de origem - desenvolvimento de produto e produção - para atuar em projeto, planejamento e implementação de uma oferta inigualável no curto prazo por seus concorrentes e na distribuição.

- $\quad$ A empresa B1 é um caso onde este travamento na posição já ocorreu em relacionamentos passados. Houve situação em que a organização tinha sua receita atrelada a uma parceira internacional, que decidiu atuar diretamente na América Latina. O entrevistado nesta organização se mostrou consciente dos riscos deste evento ocorrer de novo no ecossistema do qual faz parte. Foi reconhecida a fragilidade da estudada na relação com a líder da cadeia.

- $\quad$ A empresa B2 é um caso no qual o aperfeiçoamento competitivo pode ser um desafio. Trabalha em uma GVC dominada pelos compradores, com fornecedores poderosos. É possível que os fornecedores tenham interesse em mantê-la nesta posição. Parece certo que sua posição na cadeia é muito mais influenciada pelos compradores e fornecedores, do que pelos seus próprios objetivos e planos estratégicos. A empresa, por estar direcionada para as grandes empresas e governo, conta, naturalmente com um número pequeno de compradores. Foi declarado pelos entrevistados que a organização é muito cuidadosa com o tema concentração, não só em clientes, mas também em setores. Este cuidado reflete esta fragilidade mencionada. Este caso também se enquadra no que é mencionado como comum: embora haja forte atividade de marketing em distribuição e comunicação com o objetivo de venda, a empresa, conforme foi declarado, não desenvolve seus próprios produtos e a marca é importante como atestado de longevidade da organização. Também, a empresa parece dependente de relacionamentos.

- $\quad$ O caso B3 apresenta muitas semelhanças com o caso B2. A possível diferença é que, pelo que esta empresa declara, tem investido em novos produtos com o perfil de geração de rendas mais altas. Esta preocupação pareceu mais clara na B3 do que na B2. Também, a B3 
tem investido em compra de empresas, como foi declarado pelos entrevistados e como tem sido divulgado com freqüência no noticiário.

- $\quad$ O caso C1 também é típico do que descrever Humphrey (2003, p. 18-19): (1) Sua receita advém de um pequeno número de compradores (não só o segmento bancário é concentrado, nas demais atividades financeiras como, por exemplo, seguros também há concentração em poucas organizações). (2) É especializada em soluções para o segmento, segundo as declarações dos entrevistados. (3) Há poucos casos que conheçam de construção de marcas, denotando que no seu julgamento este instrumento é pouco relevante. (4) Os entrevistados declararam acreditar na força do que chamam de marketing de relacionamento. (5) Foram mencionados casos em que o comprador no exterior demandou exclusividade, pelo menos durante um determinado período de tempo. Foi observado que o comprador queria impedir a concorrência de ter acesso à tecnologia, pouco comum à época da venda. Hoje, os compradores globais já lograram desenvolver outros fornecedores para a solução.

- $\quad$ O caso C2 apresenta muitas semelhanças com as empresas B2, B3 e C1. A diferença com a C1 é que o líder da cadeia é o fornecedor de equipamentos. Foi declarado que o número de compradores chega a poucas dezenas. Sua solução é muito especializada. O histórico da organização é de produção, seus fundadores são especialistas nos produtos comercializados.

Foi verificado que as empresas estudadas desenvolvem ações que podem ser entendidas como iniciativas para combater o travamento em relacionamentos vulneráveis a novas formas de competição. O quadro 43 traz um resumo das opções estratégicas que foram observadas nos casos estudados. 


\begin{tabular}{|c|c|c|c|}
\hline EMPRESA & $\begin{array}{l}\text { DIVERSIFICAÇÃO } \\
\text { DE MERCADOS }\end{array}$ & $\begin{array}{c}\text { EXCELÊNCIA } \\
\text { PRODUTIVA }\end{array}$ & $\begin{array}{c}\text { USO EFICAZ DE } \\
\text { CONHECIMENTO DA } \\
\text { CADEIA } \\
\end{array}$ \\
\hline A1 & $\mathbf{X}$ & & $\mathbf{X}$ \\
\hline A2 & $\mathbf{x}$ & & $\mathbf{X}$ \\
\hline A3 & $\mathbf{x}$ & $\mathbf{X}$ & \\
\hline B1 & & & $\mathbf{X}$ \\
\hline B2 & $\mathbf{X}$ & $\mathbf{X}$ & \\
\hline B3 & & $\mathrm{X}$ & $\mathbf{X}$ \\
\hline C1 & $X$ & $\mathbf{X}$ & $\mathbf{X}$ \\
\hline C2 & $\mathbf{X}$ & & \\
\hline
\end{tabular}

FONTE: AUTOR, 2008, com conceitos de HUMPHREY, 2003, p. 18-19.

Portanto, a opção mais comum é a diversificação de mercados. Esta diversificação é, principalmente, geográfica. Isto pode significar a operação em várias redes, o que não é necessariamente positivo. Há controvérsias sobre este tipo de atuação (DUGUID, 2005, p. 405 e 510).

Com relação às empresas que atuam como sub-contratadas - B2 e B3 - foi verificado que: - $\quad$ A empresa B2 não tem capacidade de desenvolver produtos próprios, o foco de sua atuação, conforme declarado, é a prestação de serviços com produtos de terceiros. A empresa B3 já mostra alguma capacitação nesta direção, com fábrica de software, mas ainda de forma muito incipiente. Ambas as empresas possuem capacitação em outros aspectos do marketing, como comunicação e distribuição. Portanto, desta avaliação se pode afirmar que, de acordo com a definição de Camuffo et al (2005, p. 2) a empresa B2 teria um perfil tradicional e a empresa B3 um perfil incerto. As demais empresas estudadas não operam como subcontratadas.

Com relação à conclusão de Elfring e Baven (1996, p. 223) sobre a relação entre a habilidade de aprender de clientes exigentes e o aperfeiçoamento funcional, só se pode falar neste tipo de aperfeiçoamento no caso da empresa A3. Neste caso, o aperfeiçoamento funcional não parece ter vindo de clientes exigentes, mas da necessidade da empresa de construir barreiras à 
entrada de concorrentes, complementando sua oferta em automação comercial. Com relação ao desmembramento externo de competências, pode-se afirmar que:

- $\quad$ Ocorre no caso A2, com suas franquias de desenvolvimento e distribuição.

- $\quad$ Ocorre no caso A3 com o desenvolvimento na Ásia e fabricação na China.

- $\quad$ Ocorre no caso B1, com a modelagem da rede de fornecedores para desenvolvimento da oferta na América Latina.

- $\quad$ Pode ocorrer também no caso C1 com o desenvolvimento na Índia.

Quanto às conclusões de Dedrick e Kraemer (1998, p. 211-215) sobre o sucesso competitivo em TI, no tocante ao foco no segmento, o que pareceu foi que as organizações objeto deste estudo primeiro escolheram o segmento e depois foram buscar o desenvolvimento de capacitações. O quadro 44, que segue, traz mais detalhes com relação aos segmentos abordados pelas empresas estudadas.

Quadro 44 - Segmento foco da atuação das empresas estudadas

\begin{tabular}{|c|c|c|}
\hline \multirow{2}{*}{ EMPRESA } & \multicolumn{2}{|c|}{ SEGMENTO FOCO } \\
\cline { 2 - 3 } & QUANTO À ATUAÇÃo & QUANTO AO PORTE \\
\hline \multirow{2}{*}{ A1 } & Geral & Médias e grandes empresas \\
\hline A3 & Geral & PMEs \\
\hline B1 & $\begin{array}{c}\text { Varejo } \\
\text { (principalmente) }\end{array}$ & PMEs \\
\hline (principalmente)
\end{tabular}

FONTE: AUTOR, 2008, com base nas conclusões de DEDRICK; KRAEMER, 1998, p. 211215, aplicados aos casos estudados (informações obtidas na pesquisa de campo).

Nos casos estudados, não se pode falar em atuação altamente focada, como pode ser verificado pelo exame das informações dispostas no quadro 45. A empresa com maior foco 
em um segmento é a C1, no setor financeiro. As empresas estudadas, embora pioneiras na atividade no Brasil, aproveitaram oportunidades criadas por terceiros, quando se coloca uma perspectiva global neste escrutínio. A empresa que se poderia argüir ter definido um novo mercado é a A3. No entanto, mesmo neste caso, o mercado não foi definido pela empresa. Muito do desenvolvimento da automação comercial no Brasil nos últimos anos se deve às exigências do fisco. Este fenômeno é reconhecido pela empresa. Tem ocorrido também em outros países: foi citada a Venezuela.

Com relação à associação entre sucesso e rapidez e flexibilidade para decidir, isto foi observado especialmente nos casos B2 e B3. No caso B3, chamou a atenção as freqüentes reorganizações empreendidas pela empresa. Contudo, as empresas estudadas mencionaram quase que unanimemente a importância da escala no negócio de TI. Mesmo empresas especializadas como a C1 estão empenhadas na busca de escala. A questão dos custos irrecuperáveis apareceu no caso A1, pois o sistema de licenças de uso (LUs) está em uma fase descendente, com a emergência dos programas baseados na web. Esta empresa parece estar consciente da necessidade de mudar e não parece constrangida pelos investimentos prévios realizados. A empresa A3 redirecionou a atividade de desenvolvimento de produto para a Ásia. Não foi mencionado qualquer problema com relação aos investimentos realizados no Brasil nesta atividade. Da mesma forma, a empresa tem fabricado alguns produtos na Ásia, também sem que houvesse menção à questão dos investimentos prévios. O caso B1 também tem reestruturado sua atuação, inclusive no exterior - foram mencionados vários casos pelo entrevistado - sem considerações quanto aos investimentos prévios realizados.

Contudo, tanto em relação à atuação altamente focada em segmentos, como em relação à questão do porte e dos investimentos irrecuperáveis cabe um alerta. O mercado brasileiro de TI, evidentemente, é menor do que o mercado dos países desenvolvidos. Em mercados menores, é esperado que ocorra uma menor segmentação da atuação das empresas, em virtude dos segmentos também serem menores. No que tange ao porte das organizações, os conceitos grande ou pequeno precisam ser contextualizados. O que é considerado uma organização de grande porte no Brasil, já com capital aberto na bolsa de valores, pode significar pequeno porte em um país desenvolvido.

A ilustração 14 e os quadros 22, 23, 24, 25, 26, 27 e 28, elaborados com conceitos da abordagem $G V C$, em linha com o argumento de Kaplinsky et al (2003, p. 7), jogam luz na 
forma pela qual os casos estudados estão entrando nos mercados globais. Nos casos B2 e B3 está presente o elemento da terceirização de atividades das multinacionais. Contudo, as empresas estudadas A1, A2 e A3 desempenham este papel de líderes das cadeias. As empresas C1 e C2 se concentram em atividades com maior conteúdo de conhecimento, como desenvolvimento, desenvolvimento de marcas, marketing e serviço de pós-venda (ou sua gestão através de terceiros).

Quanto à existência de uma seqüência no aperfeiçoamento competitivo em cadeias de valor, as empresas que mais se assemelham a OEMs (Original Equipment Manufacturers) ou ODMs (Original Design Manufacturers), que são aqueles que fornecem partes ou produtos inteiros para colocação da marca de terceiros são as empresas B1, B2 e B3. No caso da empresa B1 existe um grau elevado de conhecimento na tarefa desenvolvida. Não só do ponto de vista técnico, mas também no aspecto de inteligência de mercado, elaboração de sofisticados esquemas financeiros, muitas vezes envolvendo os governos dos países. A empresa B3, além da fábrica de software inaugurada, declara usar os produtos padronizados, nos quais obtém baixas rendas, por razões estratégicas. As empresas A1, A2, A3, C1 e C2 desenvolvem ou fazem a gestão do desenvolvimento de seus próprios produtos, colocando neles suas marcas. Portanto, podem ser classificados de OBMs (Original Brand Manufacturers). É interessante destacar que as empresas A1, A3 e C1 utilizam outras empresas como OEMs ou ODMs. Em seguida é apresentado um resumo dos casos estudados quanto a este aspecto (QUADRO 45). 
Quadro 45 - Classificação dos casos estudados quanto à utilização de marcas (próprias ou de terceiros)

\begin{tabular}{|c|c|}
\hline EMPRESA & CLASSIFICAÇÃO \\
\hline A1 & OBM \\
\hline A2 & OBM \\
\hline A3 & OBM \\
\hline B1 & OEM/ODM \\
\hline B2 & OEM/ODM \\
\hline B3 & OEM/ODM \\
\hline C1 & OBM \\
\hline C2 & OBM \\
\hline
\end{tabular}

FONTE: AUTOR, 2008, com base nos conceitos de KAPLINSKY ET AL, 2003, p. 34, aplicados aos casos estudados (informações obtidas na pesquisa de campo).

Portanto, diferente do que é apontado como mais comum para as empresas de países em desenvolvimento, a grande maioria dos casos estudados desenvolve suas próprias marcas. Nos casos B1, B2 e B3, em que isto não ocorre, a inserção global nem sempre é de baixo nível.

O quadro 46, que segue, traz os determinantes que Schmitz e Knorringa (1999, p. 24) consideram mais estratégicos e relevantes para o aperfeiçoamento competitivo, aplicados aos casos estudados.

Quadro 46 - Aperfeiçoamento competitivo e oportunidades nos casos estudados

\begin{tabular}{|c|c|c|}
\hline \multirow{2}{*}{$\begin{array}{l}\text { SEGMENTO DE } \\
\text { MERCADO }\end{array}$} & \multicolumn{2}{|c|}{ CONCENTRAÇÃO DOS COMPRADORES } \\
\hline & Alta & Baixa \\
\hline Foco em preço & B2 / B3 / C2 & --- \\
\hline $\begin{array}{r}\text { Foco em qualidade ou outros } \\
\text { fatores }\end{array}$ & A1 / B1 / C1 & A2 / A3 \\
\hline
\end{tabular}

FONTE: AUTOR, 2008, com base nos conceitos de SCHMITZ; KNORRINGA, 1999, p. 24, aplicados aos casos estudados (informações obtidas na pesquisa de campo).

Portanto, ainda de acordo com o esquema de Schmitz e Knorringa (1999, p. 24), o que deveria ocorrer nos casos estudados quanto às oportunidades de aperfeiçoamento competitivo e ganhos segue: 
- $\quad$ Casos B2, B3 e C2: aperfeiçoamento competitivo baixo e ganhos assimétricos.

- $\quad$ Casos A1, B1 e C1: aperfeiçoamento competitivo alto e ganhos assimétricos.

- $\quad$ Casos A2 e A3: Aperfeiçoamento competitivo alto e ganhos equilibrados.

Com relação ao aperfeiçoamento competitivo, os casos B2 e B3 tendem a confirmar a classificação apresentada. O caso B3 procura se movimentar para atividades que oferecem renda mais alta, procurando, portanto, se afastar desta classificação. A assimetria dos ganhos seria real, pois estes estariam concentradas nos compradores e nos desenvolvedores de sistemas, os parceiros poderosos destas empresas. O caso C2 foca em preço, mas talvez não necessitasse fazê-lo, ou pelo menos não com a intensidade que foi declarada. É possível que os parceiros no exterior estejam se apropriando de uma parte dos ganhos desta empresa.

No caso das empresas A1, B1 e C1, as três parecem confirmar o aperfeiçoamento competitivo, alto, previsto para esta situação. Nos casos A1 e B1 a assimetria dos ganhos parece favorecer estas duas organizações. No caso C1 não é possível tecer considerações sobre este aspecto.

As empresas A2 e A3, no tocante ao aperfeiçoamento competitivo parecem confirmar a classificação proposta. A empresa A2 tem incorporado outras empresas com velocidade. A empresa A3 é a única da amostra na qual ocorreu aperfeiçoamento funcional. No caso A2, parece haver assimetria de ganhos a favor da empresa. No caso A3, as novas funções na cadeia ainda não renderam o resultado esperado por questões organizacionais e relacionadas à tecnologia, segundo o entrevistado. Portanto, não é possível fazer considerações sobre a distribuição dos ganhos neste último caso. No caso A2, existe um outro fator que pode estar influenciando os resultados da empresa positivamente: embora não tenham sido comparados os balanços das estudadas quanto a este item, segundo as declarações obtidas, pode-se concluir que esta organização trabalha com custos fixos mais altos do que os concorrentes. No caso de um aumento nas vendas a tendência é uma amortização dos custos fixos, diferente dos concorrentes que contam com proporções distintas de custos fixos e variáveis.

Quanto às características das redes de produção que levam a um desempenho econômico superior, aquela da qual faz parte a empresa B1 parece possuí-las: as empresas participantes da rede, B1 inclusive, segundo as declarações obtidas, contam com alto grau de autonomia e compartilham conhecimento codificado em escala global. No esquema de Sturgeon (2002, p. 
487), os fornecedores provêem os processos básicos. As indicações obtidas sugerem que este é o papel da líder da cadeia, a empresa originária dos EUA. A rede da qual faz parte a empresa estudada possui também outras características coincidentes com o esquema descrito: caráter aberto, flexibilidade organizacional, flexibilidade geográfica de produtos e clientes. Pelas informações obtidas, não seria surpresa se as barreiras de entrada, excetuando a técnica, sejam baixas, embora não tenham sido obtidos detalhes sobre este aspecto. Portanto, estas características em conjunto, levariam a um desempenho da rede que teria como característica custos totais e riscos mais baixos.

Em seguida é apresentado um resumo das barreiras à entrada quanto à durabilidade e capacitação das empresas para se movimentar para atividades nas quais as altas barreiras prevalecem (QUADRO 47).

\section{Quadro 47 - Nível das barreiras à entrada de concorrentes nos casos estudados e respectiva capacitação dinâmica}

\begin{tabular}{|c|c|c|}
\hline EMPRESA & $\begin{array}{c}\text { NÍVEL DAS } \\
\text { BARREIRAS }\end{array}$ & $\begin{array}{c}\text { CAPACITAÇÃo } \\
\text { DINÂMICA }\end{array}$ \\
\hline A1 & Discretamente baixo & Discretamente alto \\
\hline A2 & Alto & Discretamente baixo \\
\hline A3 & Alto & Alto \\
\hline B1 & Muito alto \\
\hline B2 & Baixo & Discretamente baixo \\
\hline B3 & Discretamente baixo & Discretamente alto \\
\hline C1 & Discretamente alto & Discretamente alto \\
\hline C2 & Discretamente alto & Discretamente baixo \\
\hline
\end{tabular}

FONTE: AUTOR, 2008, com base nos conceitos de KAPLINSKY; MORRIS, 2003, p. 43, aplicados aos casos estudados (informações obtidas na pesquisa de campo).

Segue breve explanação das razões da classificação das organizações estudadas quanto ao nível das barreiras à entrada de concorrentes e sua capacitação dinâmica.

- $\quad$ No caso A1, o nível das barreiras à entrada é discretamente alto, pois em termos de tecnologia, como o próprio entrevistado admite, o conhecimento está cada dia mais difundido e, portanto, as barreiras à entrada, neste aspecto são a cada dia mais baixas. Resta à empresa a 
escala, contudo, em relação às concorrentes internacionais seu porte é reduzido. Com relação à capacitação dinâmica, a reorganização ocorrida a partir de 1999, que resultou na atual estrutura organizacional, além de reforçar as barreiras à entrada, trouxe indicações que a empresa tem a habilidade de rever seus procedimentos de gestão e encontrar novos caminhos. - $\quad$ No caso A2, o nível das barreiras à entrada é alto em função do foco da empresa nas PMEs. Sua classificação quanto à capacitação dinâmica está no nível médio em função de não terem sido observadas revisões do modelo que justificassem um patamar mais alto.

- $\quad$ No caso A3, as barreiras à entrada foram classificadas no nível alto em função da completude da solução desenvolvida pela empresa. Com relação à classificação da empresa no quesito capacitação dinâmica, o nível alto se deve à evolução ocorrida no sentido de terceirizar fora do país o desenvolvimento de produto e à fabricação na Ásia para o mercado dos EUA. A reorganização em curso para a completude da solução também pesou nesta classificação.

- $\quad$ Na empresa $\mathbf{B 1}$ o nível das barreiras é discretamente alto. A barreira à entrada se deve à complexidade tecnológica. Contudo, é fácil entrar e sair da rede. Ou seja, uma vez superada a questão da capacitação técnica, a barreira é baixa. Contudo, esta organização pode ser entendida como um exemplo de movimentação sistemática para atividades onde prevalecem barreiras (e rendas) mais altas.

- $\quad$ No caso B2, como é admitido pela própria empresa, as barreiras à entrada de concorrentes são baixas. Não foram notadas indicações que esta organização desenvolveu capacitação dinâmica para se movimentar para atividades nas quais as barreiras altas prevalecem.

- $\quad$ No caso B3, o nível das barreiras foi considerado discretamente baixo, pois a empresa busca atividades mais sofisticadas, nas quais as barreiras à entrada são mais altas do que nas menos complexas. O mesmo racional foi aplicado à classificação da capacitação dinâmica desta organização.

- $\quad$ O nível das barreiras foi classificado como discretamente alto no caso $\mathbf{C 1}$ devido à completude e à especialização da oferta da empresa. A capacitação dinâmica foi percebida como classificada como de nível médio-alto, em função da revisão organizacional que a empresa tem empreendido, que resultou em uma série de fusões e aquisições e perspectiva de abertura de capital no segmento BovespaMais da bolsa paulista.

- $\quad$ O nível das barreiras à entrada no caso C2 foi classificado como discretamente alto em função da sofisticação tecnológica da solução para a gestão eletrônica de documentos e da 
solidez da parceria com a fabricante de equipamentos. Com relação à capacitação dinâmica, foi classificada de nível discretamente baixo, pois não foi percebida nenhuma indicação de movimentação para atividades com barreiras à entrada mais altas.

Quanto às características da oferta das organizações estudadas, a avaliação é que os sistemas tendem a ser mais abertos e terceirizados, portanto mais sensíveis a vazamentos. A exceção é a empresa C2, cujo sistema conta com maior imobilidade e especificidade.

Todas as empresas estão envolvidas em cadeias locais e cadeias internacionais. Contudo, somente a empresa A3 está envolvida em cadeias com perfis diferentes. As cadeias locais diferem das globais, não quanto ao padrão de governança, mas a sua intensidade, como foi reconhecido por alguns dos entrevistados nos casos estudados. Isto também foi reconhecido pelo entrevistado no caso A3. Portanto, se for considerada a cadeia global como outra cadeia, há convergência com os resultados da pesquisa de Bazan e Navas-Alemán (2001) junto aos calçadistas do Vale dos Sinos, Rio Grande do Sul, Brasil. Contudo, se for considerado o conceito de envolvimento em cadeias com perfil diferente, inclusive quanto a produto, somente no caso A3 pode ser verificada esta convergência.

Não se pode afirmar que os resultados desta pesquisa convergem com os da de Gereffi (1999) em confeccionados têxteis. As indicações são que o envolvimento global traz novas referências e oportunidades às empresas estudadas, mas o caso onde houve aperfeiçoamento funcional (A3), isto ocorreu a partir da cadeia local, onde o processo está mais avançado. Esta empresa ainda se encontra em processo de operar com a oferta completa no exterior. Mesmo no mercado local, a ampliação do escopo de atuação ocorreu com problemas. Portanto, a evolução não é, neste caso, conseqüência da atividade de exportação.

Quanto às questões colocadas por Humphrey e Schmitz (2000, p. 12-13), foi verificado aperfeiçoamento na esfera da produção nos casos A1, A2, A3, B1, B2, C1 e C2. Portanto, aqui há convergência com a literatura. Não se pode dizer nada a respeito da exclusão de outros produtores, em geral, embora isto tenha sido mencionado nos casos B2 e C2. No caso B2, possivelmente devido ao preço mais baixo, contudo no caso C2, a tecnologia da empresa brasileira era, à época, superior e adequada ao que especificavam os compradores. A sucessão de compradores ocorre no caso B3. Entretanto, cabe notar que a atuação internacional desta 
empresa é muito tímida. No entanto, parece que esta é mais um esforço da empresa estudada, do que um empenho deliberado dos compradores em desenvolver seus fornecedores.

Com relação à concentração da inovação estratégica nos países desenvolvidos, isto foi observado em todos os casos, coincidindo, portanto, com as conclusões de Lastres et al (1999). Os entrevistados nas empresas estudadas parecem estar conscientes deste fato. A empresa A3 mantém um escritório na Europa para acompanhar a evolução do estado da arte da atividade de automação comercial.

A empresa B1, que participa de uma rede e nela tem papel regional de importância, integra tecnologias de fora, segundo declarações do entrevistado.

No tocante aos argumentos de Ponte (2006, p. 26), foi verificado que, nos casos B1, C1 e C2, nos quais a liderança é desempenhada por empresa estrangeira, esta coordenação parece ser informal. Foram obtidas indicações de que o mesmo ocorre na empresa A3, onde a governança exercida pela empresa tem características menos formais. Nos casos das empresas A1, A2, B2 e B3, não foram obtidas indicações de menor formalidade das relações.

Diferente da constatação de Schmitz e Knorringa (1999, p. 19-21), neste estudo foram obtidas evidências de aperfeiçoamento competitivo fora da esfera produtiva (QUADRO 48). 
Quadro 48 - Evidências do aperfeiçoamento competitivo (AC) fora da esfera produtiva

\begin{tabular}{|c|c|}
\hline EMPRESA & EVIDÊNCIA \\
\hline A1 & $\begin{array}{c}\text { AC de processo. Ocorreu através da estrutura organizacional, que tem a capacidade de } \\
\text { influenciar o comportamento no processo de desenvolvimento e distribuição. }\end{array}$ \\
\hline A2 & AC de produto \\
\hline A3 & AC de produto e funcional \\
\hline B1 & AC de produto \\
\hline B2 & Neste caso se pode falar de AC de processo na esfera produtiva, mas também ocorreu AC de \\
produto.
\end{tabular}

FONTE: AUTOR, 2008, com conceitos de SCHMITZ; KNORRINGA, 1999, p. 19-21, aplicados aos casos estudados (informações obtidas na pesquisa de campo).

Portanto, como pode ser concluído no exame das informações dispostas no Quadro 48, o aperfeiçoamento competitivo que ocorreu foi na maior parte dos casos fora da esfera produtiva. Somente nos casos B2 e B3 é que se pode falar de aperfeiçoamento competitivo na esfera produtiva. Contudo, nestes dois casos houve também aperfeiçoamento competitivo de produto. No entanto, são dois dos três casos estudados em que a cadeia é governada pelo comprador. Portanto, como indicam Schmitz e Knorringa (1999, p. 19-21), a limitação pode estar na forma de governança da cadeia.

Diferente do que encontraram Bazan e Navas-Alemán (2001, p. 63), a empresa mais envolvida com uma cadeia dos EUA é a B1. Neste caso não se pode afirmar que esta cadeia é hierárquica. Ao contrário. Dentre as estudadas, é a que se encontra operando mais perto do que é definido como uma rede.

Com relação às empresas brasileiras estudadas, as três que governam suas respectivas cadeias - A1, A2 e A3 - seguiram estratégias diversas, conforme aponta Whitley (1996, p. 419-420), mas também é possível encontrar similaridades: 
- $\quad$ A empresa $\mathbf{A 1}$ opera com foco em médias e grandes empresas. A estrutura de desenvolvimento e distribuição foi organizada de forma a estimular o comportamento empreendedor e oferecer os incentivos que a empresa julga corretos aos agentes.

- $\quad$ A empresa A2 opera com foco em PMEs. Sua estrutura de desenvolvimento é verticalmente integrada. Sua estrutura de distribuição é 50\% verticalmente integrada; os outros 50\% são operados sob o sistema de franquias de distribuição.

- $\quad$ A empresa A3, inicialmente operava com um produto distinto da A1 e da A2. Também tem uma estrutura fortemente apoiada em terceiros. Seu foco está nas PMEs, embora esteja procurando aumentar sua participação nas organizações de maior porte. Houve evolução para outra função na cadeia, na qual o produto vendido guarda similaridade com o da A1 e da A2. - $\quad$ Quanto às similaridades, o que mais chamou a atenção foi a busca em se oferecer uma solução completa aos compradores. É possível que as empresas estudadas entendam a completude como uma barreira à entrada de concorrentes. Outro aspecto que deve ser destacado nas empresas A1 e A2 é a quasi-hierarquia encontrada na distribuição nos dois casos. Na empresa A2, mesmo nos 50\% da distribuição que são terceirizados, a cadeia é fortemente governada pela empresa. Outra similaridade encontrada nas três empresas é a busca por economias de escala e de escopo. As três empresas (A1, A2 e A3) buscam a expansão na América Latina.

No tocante ao fluxo de informações, conforme observam Dedrick e Kraemer (1998, p. 221), foram encontrados pelos menos dois casos notáveis:

- $\quad$ A empresa A3 mantém escritórios no exterior para acesso à tecnologia e informações sobre desenvolvimento de produto.

- $\quad$ Os executivos da empresa C1 mantêm uma rede de pessoas físicas em conexão informal para a busca de informações.

Um outro caso interessante é o B2, pois as multinacionais, nas quais o Brasil é representativo nas respectivas operações mundiais, são procuradas no exterior, preferencialmente, pois é sabido que a compradora potencial pode buscar informações sobre a estudada muito rapidamente junto à filial. Quanto maior a importância da filial para a compradora potencial, mais provável é de que sejam recebidas informações de forma rápida e precisa. 
Em linha com o que afirma Dosi (1997, p. 468) o arquétipo estadunidense encontrado não é o típico deste país, mas parece ser bem sucedido (CASO B1). Nas empresas estudadas ainda são encontrados os fundadores, em maior ou menor intensidade na gestão, embora todas estejam com a profissionalização da gestão em andamento. A exceção é a empresa B1, cujo capital pertence aos funcionários, em um sistema semelhante com uma sociedade de serviços profissionais. Embora não se tenha obtido informações mais detalhadas sobre este aspecto, a informação obtida é que somente funcionários na ativa podem ser acionistas, o que significa isto foi confirmado - que os fundadores ou suas famílias não estão mais no quadro societário ou na gestão da empresa.

No tocante aos modelos de produção em rede propostos por Sturgeon (2002, p. 481), pode-se afirmar que:

- $\quad$ O modelo da empresa A1 tem as características do modelo japonês (rede hierárquica exclusiva).

- $\quad$ O modelo da empresa A2 se assemelha à organização moderna (integração vertical).

- $\quad$ O modelo seguido pela empresa B1 segue o chamado novo modelo dos EUA, com capacidade produtiva compartilhada na rede modular.

Nos demais casos estudados, não é possível classificar os casos de acordo com os modelos apresentados por Sturgeon (2002, p. 481).

Em sintonia com o que coloca Williamson (1975, p. 104-105 e 117), algumas das organizações estudadas - A2, B2, B3 e C2 - a integração vertical foi a forma de organização escolhida. Houve casos em que foram mencionados aspectos que podem ser relacionados à economia dos custos de transação e harmonização de interesses. No caso A3, foi mencionado que a atividade de projeto é mantida verticalmente integrada por razões estratégicas. Pode ser entendido neste caso que esta forma permite a ativação de processos de controle. O mesmo ocorre no caso A2, onde a integração vertical de parte da distribuição foi implementada para controle da parte terceirizada, bem como para ativação de incentivos de desempenho. Nos casos B2 e B3 esta questão da ativação de incentivos e processos de controle pareceu emergir na gestão de pessoas. A questão levantada da preservação da atmosfera - empreendedora interna parece surgir no caso A1, onde foram implementadas as franquias com este objetivo. Possivelmente, os gestores entenderam que neste caso ocorriam deseconomias nos custos de transação. 
No tocante às observações de Sturgeon (2002, p. 485), há o risco das empresas estudadas, em virtude de já serem de capital aberto em alguns casos ou estarem, em outros casos, em preparativos para a abertura de capital, se tornar demasiadamente interessadas nos lucros de curto prazo. Uma situação desta natureza parece ter ocorrido no caso A3, no qual houve venda de ações por parte de investidores estrangeiros, após alguns trimestres de resultados abaixo do esperado. Estes resultados decorreram das dificuldades de integração das organizações compradas, que permitem à estudada a completude da oferta. Por esta razão - completude - e outras, é reconhecido que a estratégia pode fazer sentido, mas a reação dos investidores parece um incentivo à abordagem de curto prazo por parte da empresa. Segue uma lista das práticas adotadas pelas empresas quanto à obtenção de vantagens competitivas:

- $\quad$ A1. Pode-se falar em redução de níveis hierárquicos com a criação das franquias de desenvolvimento e distribuição, embora este não tenha sido o principal motivador da medida. Também há envio da produção para locais com salários mais baixos. Um caso mencionado é a Argentina, embora certamente este fator não possa ser mencionado como o único motivador para esta ação e possivelmente não é o principal.

- $\quad$ A2. Há envio da produção para locais com salários mais baixos (Argentina), embora este não seja o principal motivador da decisão. A empresa não utiliza trabalhadores temporários.

- $\quad$ A3. Foi declarado que a organização tem enviado a produção para locais com salários mais baixos e usa o procedimento de pressionar fornecedores.

- $\quad$ B1. Não foram encontradas práticas que confirmem a percepção de que a empresa obtém as chamadas vantagens competitivas de baixo nível.

- $\quad$ B2. Embora a empresa utilize práticas como o envio da operação para locais com custos mais baixos, como o interior do estado de São Paulo, a percepção é que as vantagens competitivas são obtidas principalmente através de disciplina e treinamento. De modo geral, também foi percebido que há enorme foco na produtividade.

- $\quad$ B3. Há utilização de envio de atividades para locais com salários mais baixos. Contudo, neste caso também a percepção é que se procura obter vantagens competitivas mais através do planejamento prévio do que por procedimentos entendidos como de baixo nível. - $\quad$ C1. A empresa envia atividades para locais com custos de mão-de-obra mais baixos, como a Índia. 
- $\quad$ C2. Como no caso B1, não foram encontradas práticas que confirmem a percepção de que a empresa obtém as chamadas vantagens competitivas de baixo nível.

Portanto, em seis dos oito casos estudados, estas práticas associadas à obtenção de vantagens competitivas de baixo nível, são utilizadas.

Com relação à proposta de Dosi (1997, p. 468-479) sobre a coordenação de processos complexos de produção e distribuição, mesmo no caso C2, onde isto corre em menor escala, pode-se dizer que a complexidade se faz presente. No mínimo pela atuação internacional de todos os casos estudados, que por si já seria um fator de complicação. Contudo, como as empresas estudadas, em sete dos oito casos, produzem somente serviços, esta complexidade é potencializada. A prestação de serviços exige o envolvimento local, nesta circunstância, no exterior. Em um caso o produto é um serviço, acoplado de várias formas equipamentos, o que caracteriza uma solução completa, com complexidade talvez ainda maior do que os demais casos estudados. Outro fator é a complexidade tecnológica. Embora as empresas estudadas não desenvolvam tecnologia, a utilizam e para ter vantagem competitiva procuram utilizar o que está na fronteira do conhecimento. As empresas A2 e A3 estão direcionadas para PMEs, o que aumenta a complexidade do processo de distribuição.

Uma evidência que a transferência de formas organizacionais é limitada é o caso da empresa A1 no México. A organização estudada montou uma empresa de distribuição, da qual detém 100\% das ações para estimular através de um caso real o empresariado local a investir no negócio. Com relação à diversificação dos atores empresariais, não parece haver coincidência com o que propõe Dosi (1997 p. 468-478). Todas as estudadas podem ser classificadas de empresas emergentes. Também se pode afirmar que são menos diversificadas do que os exemplos mencionados de países em desenvolvimento.

No tocante às considerações de Schmitz (1999A, p. 139), a estrutura de desenvolvimento e distribuição montada no caso A1 vai ao encontro desta noção de que os agentes econômicos são mais produtivos nas situações em que têm autonomia. No entanto, o caso A2, em uma atividade muito semelhante, optou por uma estrutura verticalmente integrada. Contudo, no caso A2, o que foi observado é que a organização está longe do estilo fordista de gestão no que tange à gestão de pessoas. Longe do estilo fordista também estão as organizações A3 e B1. Principalmente esta última com sua rede articulada globalmente. No caso A3, há várias 
estruturas em cadeia operando simultaneamente, o que confere sofisticação e complexidade à operação. A estrutura é descentralizada na operação e centralizada nas definições consideradas estratégicas. As empresas B2 e B3 operam com estruturas que lembram o estilo fordista. Principalmente a B3. No caso B2, a exemplo do que ocorre no A3 foi verificado um enorme cuidado com a gestão de pessoas. A organização C1, com suas unidades de negócio e modelo colaborativo ainda não alcançou a sofisticação do modelo das organizações A1 e B1, mas já se pode avaliar a estrutura como pós fordista. A estrutura da C2, mais convencional, funcional com verticalização e algumas cadeias ainda simplificadas, em relação a alguns dos demais casos deste estudo.

Sobre a sugestão de Fear (1997, p. 566-567) relacionada aos períodos críticos da formação da cultura empresarial, o momento atual, com a profissionalização e abertura de capital de empresas de tecnologia como são as estudadas pode ser um destes momentos. Para relacionar este fenômeno com a dependência do passado em que podem ser colocadas as empresas estudadas, uma consideração é o demasiado foco no curto prazo, que poderá impedir desenvolvimentos futuros destas organizações.

Os casos A1, A3, B1, B3 e C1 chamaram a atenção devido à falta de compromisso com o passado. No caso A1, a empresa se reorganizou nas franquias de desenvolvimento e distribuição, em um movimento aparentemente radical. No entanto, no México não houve problema em rever o conceito temporariamente até que a operação estivesse estabelecida. A organização A3 terceirizou na Ásia a atividade de desenvolvimento de produto e a fabricação, que são atividades ligadas a sua origem. A empresa B1 se considera em constante e atenta transição para o próximo ciclo tecnológico para definir um nicho de atuação que lhe possibilite maiores rendas. Esta organização está disposta a rever mercados de atuação, portfólio de produtos e estrutura para atuar. O caso B3 propõe se reorganizar continuamente sem nenhum constrangimento. $\mathrm{O}$ caso $\mathrm{C} 1$ se encontra em um processo de transformar fundadores das empresas que a compõem em chefes de suas unidades de negócios, em um movimento que moderniza sua estrutura e simultaneamente busca evitar a perda de capital intelectual. Na seqüência é apresentada uma síntese destes exemplos de baixo compromisso com o passado (QUADRO 49). 
Quadro 49 - Evidências de pouco compromisso com o passado nos casos estudados

\begin{tabular}{|c|c|}
\hline EMPRESA & EVIDÊNCIA \\
\hline A1 & Reorganização nas franquias de desenvolvimento e distribuição \\
\hline A3 & $\begin{array}{r}\text { Terceirização na Ásia das atividades de desenvolvimento de produto e fabricação (para } \\
\text { determinados mercados neste último caso). Atividades ligadas à origem da empresa. }\end{array}$ \\
\hline B1 & $\begin{array}{r}\text { Constante e atenta transição para o próximo ciclo tecnológico para definir um nicho de atuação } \\
\text { que lhe possibilite maiores rendas. }\end{array}$ \\
\hline B3 & Reorganização contínua sem constrangimentos. \\
\hline C1 & Transformação dos fundadores das empresas que a compõem em unidades de negócios \\
\hline
\end{tabular}

FONTE: AUTOR, 2008, com conceitos de BARNEY, 1991, p. 99 e p. 103; COOKE; MORGAN, 1998, p. 16; HUMPHREY ET AL (1998, p. 251); MYTELKA, 2000, p. 28; TEECE ET AL, 1997, p. 509, p. 515 e p. 522-523; WILLIAMSON, 1975, p. 200; WILLIAMSON, 1996, p. 240-241, WILLIAMSON, 2002, p. 110, aplicados aos casos estudados (informações obtidas na pesquisa de campo).

Claro que isto se aplica a todos os casos estudados, mas especialmente as empresas A2, B2 e C2 precisam estar atentas para evitar que a dependência do passado seja um constrangimento no seu desenvolvimento. Humphrey (1998, p. 251) explica que em um contexto de mudança radical, como o que está ocorrendo em muitos países em desenvolvimento, a dependência do passado cria constrangimentos à capacidade da empresa responder criativamente às circunstâncias dinâmicas.

Contudo, todas as empresas estudadas estão neste aspecto em uma situação privilegiada, pois como notam Knight e Cavusgil (2004, p. 137), na ausência do peso de uma herança administrativa, aquelas organizações que começaram mais recentemente e de menor porte, podem desempenhar um papel de maior importância no contexto internacional. A empresa C2 deveria avaliar cuidadosamente este aspecto. Neste caso é possível avaliar muitos aspectos positivos: a sugestão de que os fundadores pensam na sucessão em termos já operacionais, alteração no relacionamento com os colaboradores que já foi implementada e criação de uma diretoria para os assuntos tecnologia e novos produtos. Como estas mudanças são recentes e algumas das medidas ainda se encontram em fase de estudo e outras com a implementação em curso, só resta recomendar à empresa que insista neste caminho. A alteração na forma de operação no México por duas vezes também é um procedimento positivo. 
Com relação ao intento estratégico mencionado por Prahalad e Hamel (1989, p. 63-69), a seguir é exibido um resumo das ambições dos casos estudados e respectivos processos de gestão (QUADRO 50). 


\section{Quadros 50 - Intento estratégico - Objetivos e processos de gestão para sua transformação em realidade}

\begin{tabular}{|c|c|c|}
\hline EMPRESA & OBJETIVOS & PROCESSO DE GESTÃO \\
\hline A1 & $\begin{array}{l}\text { Consolidação da operação na América Latina } \\
\text { através da ampliação da rede de distribuição e } \\
\text { do crescimento. }\end{array}$ & $\begin{array}{l}\text { Operação na Argentina (significativa), } \\
\text { Chile, Colômbia e México (importante). }\end{array}$ \\
\hline A2 & $\begin{array}{l}\text { Ser a principal empresa de sistemas de gestão } \\
\text { com foco nos países em desenvolvimento. }\end{array}$ & $\begin{array}{l}\text { Operação em Portugal (compreende África } \\
\text { de língua portuguesa), México, Chile e } \\
\text { Argentina. Há um movimento de avaliação } \\
\text { de oportunidades na China e na Îndia. } \\
\text { Considera o Leste europeu. }\end{array}$ \\
\hline A3 & $\begin{array}{l}\text { - Ser a maior empresa do mundo em automação } \\
\text { comercial para o pequeno e médio varejo até } \\
2015 . \\
\text { - Empresa nasceu com ambições grandes: } \\
\text { deveria ter mais do que bons produtos, } \\
\text { fundadores desejavam construir algo diferente } \\
\text { em termos de Brasil. Desde a fundação havia } \\
\text { planos para se estabelecer fora do Brasil. }\end{array}$ & $\begin{array}{l}\text { - Estabelecimento de operações } \\
\text { internacionais, o que inclui subsidiárias no } \\
\text { exterior. } \\
\text { - Em curso avaliação de fábrica na Ásia. } \\
\text { - Prevê compras de empresas de softwares } \\
\text { nos EUA e Europa em } 2009 \text { e } 2010 .\end{array}$ \\
\hline B1 & $\begin{array}{l}\text { Ser grande empresa integradora de tecnologia } \\
\text { de ponta em toda a América Latina, a exemplo } \\
\text { do que já ocorre no Brasil. }\end{array}$ & $\begin{array}{l}\text { Avaliação ativa cuidadosa da } \\
\text { internacionalização regional (América } \\
\text { Latina), com a implantação de bases } \\
\text { operacionais locais. }\end{array}$ \\
\hline B2 & $\begin{array}{c}\text { Crescer as vendas a US\$ } 700 \text { milhões até } 2011 \\
\text { e cinco vezes em cinco anos, chegando a US\$ } 1 \\
\text { bilhão de receita anual ao final deste último } \\
\text { período. }\end{array}$ & $\begin{array}{c}\text { - Atuação em novos mercados no exterior, } \\
\text { que hoje representam } 20 \% \text { da receita, para } \\
\text { que cheguem a } 50 \% \text {. } \\
\text { - Novos produtos, mesmo que não ligados } \\
\text { diretamente à TI. } \\
\text { - Aquisição de empresas. Os mercados- } \\
\text { alvo para esta iniciativa são os EUA, o } \\
\text { México e a Inglaterra. }\end{array}$ \\
\hline B3 & $\begin{array}{c}\text { Manutenção do crescimento de forma a chegar } \\
\text { aos dois dígitos }\end{array}$ & $\begin{array}{l}\text { - Crescimento orgânico, aquisições e } \\
\text { internacionalização. } \\
\text { - Tem comprado empresas com freqüência. } \\
\text { - Contratou empresa na Europa para } \\
\text { desenvolvimento de estratégias de } \\
\text { abordagem deste mercado. } \\
\text { - Ações de comunicação nos EUA. }\end{array}$ \\
\hline C1 & $\begin{array}{l}\text { Pretende multiplicar sua receita por quatro até } \\
\qquad 2010\end{array}$ & $\begin{array}{c}\text { - Examina permanentemente empresas com } \\
\text { o objetivo de crescimento }\end{array}$ \\
\hline $\mathrm{C} 2$ & & $\begin{array}{l}\text { - Elaboração de planejamento com vistas à } \\
\text { atuação nos próximos } 15 \text { anos. }\end{array}$ \\
\hline
\end{tabular}

FONTE: AUTOR, 2008, com conceitos PRAHALAD; HAMEL, 1989, p. 63-69, aplicados aos casos estudados (informações obtidas na pesquisa de campo e também em fontes secundárias).

Além dos objetivos, as empresas estudadas parecem possuir processos de gestão para atingilos. Há evidências de novas definições, à medida que as circunstâncias se alteraram em alguns 
dos casos estudados. Cabe também um comentário relacionado à forma, pois em alguns casos o objetivo está bem estruturado e claro, mas há dúvida sobre a preparação da organização para atingi-los. Outras vezes a forma em que está colocado não deixa o objetivo claro, mas se tem a percepção que a organização está mais preparada para atingi-lo.

Segue no quadro 51 a classificação das cadeias das quais participam as empresas estudadas, conforme proposta por Gereffi (1994, p. 97-100) para a estrutura de governança,

Quadro 51 - Classificação das cadeias das quais participam as empresas estudadas

\begin{tabular}{|c|c|}
\hline EMPRESA & CLASSIFICAÇÃO \\
\hline A1 & Governada pelo produtor (empresa estudada) \\
\hline A2 & Governada pelo produtor (empresa estudada) \\
\hline A3 & $\begin{array}{l}\text { - Governada pelo comprador (empresa estudada) na situação de desenvolvimento de produtos } \\
\text { - Governada pelo comprador (empresa estudada) na situação de fabricação de equipamentos } \\
\text { para o mercado dos EUA } \\
\text { - Governada pelo produtor (empresa estudada) na situação de contratação de distribuidor nos } \\
\text { mercados estrangeiros. }\end{array}$ \\
\hline B1 & $\begin{array}{l}\text { - Governada pelo produtor, empresa originária dos EUA, líder da cadeia, fornecedora de } \\
\text { equipamentos de rede e equipamentos de gestão de rede. }\end{array}$ \\
\hline B2 & - Governada pelos compradores \\
\hline B3 & - Governada pelos compradores \\
\hline C1 & - Governada pelos compradores \\
\hline C2 & - Governada pelo produtor (fabricante de equipamentos) \\
\hline
\end{tabular}

FONTE: AUTOR, 2008, com conceitos de GEREFFI (1994, p. 97-100), aplicados aos casos estudados (informações obtidas na pesquisa de campo).

Em quatro dos oito casos estudados a cadeia é governada claramente pelo produtor. Em dois destes casos, o produtor é a empresa estudada e em outros dois, empresa fabricante de equipamentos. Em três dos casos estudados, a cadeia é governada pelos compradores. Em um caso a empresa estudada é que governa a cadeia, contudo em duas situações atua como compradora e na terceira como produtora. Neste caso A3 fica claro que a tipologia criada por Gereffi, embora útil, tem suas limitações na complexidade das relações globais. A existência dos três primeiros casos mostra que nem sempre é possível associar governança por terceiros a empresas dos países em desenvolvimento. 
Em nenhum dos mercados avaliados ocorre alta fragmentação de compradores e vendedores, que incentivaria as relações de mercado, conforme avaliam Humphrey e Schmitz (2004, p. 96-97). Esta circunstância pode ter contribuído para as relações governadas em todos os casos estudados. A situação de atuação sob encomenda também é verificada em todos os casos estudados, o que torna as previsões realizadas pelo vendedor não viáveis economicamente, incentivando a governança nas cadeias.

Em alguns dos casos estudados - A2, A3, B1, B2, C1 e C2 - foi possível observar informalidade ou incompletude nos contratos mantidos pelas empresas, conforme aponta. Williamson (1975, p. 94 e p. 107) e 2002 (2002, p. 174). Embora houvesse esta informalidade e incompletude, a repetição da interação e sua organização contribuem para caracterizar cadeias governadas, em comparação a relações de mercado e aleatoriedade (KAPLINSKY; MORRIS, 2003, p. 29). Nem sempre foi verificado que o comprador é o elo dominante, conforme sugerem Cooke e Morgan (1998, p. 59).

Conforme notam que pode ocorrer Gibbon e Ponte (2005, p. 204), a empresa A2 não externaliza um número crescente de funções, embora lidere a cadeia. O mesmo se passa no caso A3. Ambas as organizações transferem para fora atividades de forma seletiva. A situação de a empresa líder governar sem o envolvimento operacional direto, foi verificada parcialmente nos casos B1, C1 e C2. A coordenação direta com densas relações e contratuais, exclusivas, foi verificada no caso A1. A empresa B1 é um típico fornecedor de primeiro nível, que se responsabiliza regionalmente pelo contato direto com os demais fornecedores do ecossistema. Esta empresa é o que Kaplinsky (2000, p. 124-126) chama de participante fundamental da cadeia, que assume a responsabilidade pela distribuição do trabalho. É o papel chamado de complementar na identificação de oportunidades dinâmicas de obtenção de renda.

Com relação à existência de governança nas cadeias das quais participam as empresas estudadas, mesmo nos produtos avaliados como padronizados, na atividade de TI sempre há alguma adaptação, chamada de customização, ao comprador. Outra razão da necessidade que coincide com o que apontaram Dolan e Humphrey (2000, p. 150-151), diz respeito ao atendimento das exigências das empresas dos países desenvolvidos para as empresas brasileiras de TI. Foi mencionado por um dos entrevistados que as exigências para as empresas brasileiras são maiores do que aquelas feitas para as organizações originárias de um outro país em desenvolvimento, a Índia. Sobre a razão fundamental da existência de 
governança em adição a estes dois motivos, de fato nos casos estudados foi verificada a falta de competência tecnológica ou conhecimento do mercado nos casos estudados (mesmo naqueles em que a cadeia é liderada por uma empresa de origem brasileira).

De acordo com o que indicam Kaplinsky e Morris (2003, p. 67) nas entrevistas realizadas nas empresas, foi investigada a participação no poder de compra da cadeia, o controle de tecnologias fundamentais (cada dia menos relevante segundo os entrevistados) e a posse de marcas de prestígio, embora nesta última situação, muito freqüentemente a imagem de marca não é considerada importante em TI. Portanto, não se pode afirmar que, nos casos examinados neste trabalho, de acordo com as declarações obtidas, como sugere Duguid (2005, p. 523524), a marca seja uma forma de subordinar de forma quasi-hierárquica outras empresas.

Os casos A2 e C2 parecem ser o que indica Whitley (1996, p. 420-422) em termos da internalização dos riscos na estrutura (a A2 parte da distribuição é feita com terceiros). No caso da C2, como a empresa é de pequeno porte, os efeitos da complexidade gerencial ainda não foram sentidos. No caso da empresa A2, em algumas atividades como distribuição, já há uma revisão dos procedimentos operacionais.

Em termos do que coloca Sturgeon (2000, p. 15) sobre os tipos de governança, segue uma avaliação dos casos estudados:

- $\quad$ No caso A1, as franquias de distribuição têm a característica de rede baseada na autoridade, exclusivas. Ainda neste caso, as franquias de desenvolvimento têm características de redes relacionais, em aglomerados devido à localização das empresas em condomínio.

- $\quad$ No caso $\quad$ A2 a rede de distribuição também é baseada na autoridade, exclusiva.

- $\quad$ No caso A3 se parece mais com uma rede virtual.

- $\quad$ No caso B1 se trata de uma rede virtual.

- $\quad$ As redes das empresas B2, B3 e C1 se parecem com redes virtuais.

- $\quad$ O caso C2 também se parece com uma rede virtual, contudo com menos intensidade (é diferente dos casos B2, B3 e C1, por não ser governada pelo comprador).

A empresa B1 é aquela que está mais próxima do que definem Humphrey e Schmitz (2000, p. 25-27) para uma rede virtual. Contudo, seu papel, embora regionalmente importante, está longe da inovação. A empresa está focada em atuar com produtos de tecnologias que se 
encontram na fase introdutória, o que pode lhe permitir maior aprendizado por interação. Existe diferencial de competência, embora a estudada esteja em um nível muito alto. De acordo com o que foi percebido na pesquisa de campo, esta organização está consciente da fragilidade da relação. O entendimento é que, como em outras situações, a relação não tende a ser duradoura e estável.

Nos casos estudados, nas cadeias governadas pelos compradores, de forma a utilizar a estrutura de Humphrey e Schmitz (2000, p. 11), o controle é exercido conforme a seguir: - $\quad$ No caso A3, esta empresa conhece melhor as tendências do mercado. Aliás, nestes termos faz sentido o investimento realizado pela empresa em escritórios ao redor do mundo para conhecimento de tendências. Esta empresa é um caso de inserção simultânea em várias cadeias.

- $\quad$ Nos casos B2, B3 e C2, os compradores, que são grandes empresas controlam pela influencia da estrutura da cadeia e também dos sistemas de qualidade, que são especificados através de acordos sobre o nível de serviço (os chamados SLAs, do inglês Service Level Agreement).

Como apontam Bazan e Navas-Alemán (2004, p. 111 e p. 116) o aperfeiçoamento de processo e produto ocorreu com mais freqüência, em comparação com o aperfeiçoamento funcional que ocorreu só no caso A3. Contudo, nos casos estudados neste trabalho, diferente do que foi concluído sobre as cadeias locais brasileiras e as cadeias latino-americanas, não se pode falar em relações de mercado localmente e relações híbridas regionalmente. Segundo as declarações obtidas e as evidências observadas não se pode falar em diferenças entre a rede local e a rede global. Não houve casos em que a cadeia doméstica é completamente diferente do que ocorre na cadeia global.

No caso A1 ocorreu a situação que Humphrey e Schmitz (2004, p. 99-101) sugerem: a empresa decidiu terceirizar atividades e, portanto, a coordenação interna foi substituída pela governança na cadeia. Diferente do que observou Pietrobelli (1998, p. 6), em três dos casos A1, A2 e A3 - estudados foi verificado que a cadeia atua sob a governança da empresa estudada de origem brasileira. 
Com relação ao gerenciamento das cadeias de valor das quais participam as empresas estudadas, com os conceitos de Humphrey e Schmitz (2002, p. 24-27), segue no quadro 52 um resumo do que ocorre (não foram observadas relações de mercado).

Quadro 52 - Gerenciamento das cadeias de valor nos casos estudados

\begin{tabular}{|c|c|c|c|}
\hline EMPRESA & REDE & QUASI-HIERARQUIA & HIERARQUIA \\
\hline A1 & & $\begin{array}{c}\mathbf{X} \\
\text { (Desenvolvimento } \\
\text { e distribuição) }\end{array}$ & \\
\hline A2 & & $\begin{array}{c}\mathbf{X} \\
\text { (50\% da distribuição) }\end{array}$ & $\begin{array}{c}\mathbf{X} \\
\begin{array}{c}\text { (Desenvolvimento e 50\% da } \\
\text { distribuição) }\end{array}\end{array}$ \\
\hline A3 & $\begin{array}{c}\mathbf{X} \\
\text { (Desenvolvimento de } \\
\text { produtos, fabricação } \\
\text { para o mercado dos } \\
\text { EUA e vendas). }\end{array}$ & $\begin{array}{c}\mathbf{X} \\
\text { (Vendas e operações a clientes) }\end{array}$ & $\begin{array}{c}\mathbf{X} \\
\text { (Acompanhamento de } \\
\text { tendências) }\end{array}$ \\
\hline B1 & $\mathbf{X}$ & & \\
\hline B2 & & & $\begin{array}{c}\mathbf{X} \\
\text { (Desenvolvimento de software } \\
\text { no México e operações a } \\
\text { clientes em alguns dos } 13 \\
\text { países nos quais atua) }\end{array}$ \\
\hline B3 & $\begin{array}{c}\mathbf{X} \\
\text { (Elaboração de uma } \\
\text { estratégia de } \\
\text { abordagem do } \\
\text { mercado europeu) } \\
\end{array}$ & & $\begin{array}{c}\mathbf{X} \\
\text { (Prestação de serviços a } \\
\text { clientes a partir do Brasil) }\end{array}$ \\
\hline C1 & $\begin{array}{c}\mathbf{X} \\
\text { (Operação de } \\
\text { implementação em } \\
\text { outros países) } \\
\end{array}$ & & \\
\hline C2 & $\begin{array}{c}\quad \mathbf{X} \\
\text { (Operação de vendas } \\
\text { e implementação em } \\
\text { outros países) }\end{array}$ & & \\
\hline
\end{tabular}

FONTE: AUTOR, 2008, com conceitos de HUMPHREY; SCHMITZ, 2002, p. 24-27 e de WILLIAMSON, 1991A, p. 271 e 1991B, p. 80, aplicados aos casos estudados (informações obtidas na pesquisa de campo). 
Como pode ser observado no quadro 52, em três dos cinco casos estudados foi verificada mais de uma forma de gerenciamento da cadeia de valor. Com relação à rede, há vários tipos de rede. Na maior parte das vezes, este tipo de gerenciamento ocorre na atividade de vendas ou distribuição.

No que se refere à adaptação de distúrbios, só é possível fazer conjecturas. Uma delas é que este setor é de fato marcado por rápidas transformações e que a forma de gerenciamento permite às empresas diferentes reações. Uma delas está em curso, que é o declínio da cobrança de LU. No futuro, quando a transição para o novo modelo estiver mais avançada, será possível avaliar como as diferentes formas de gerenciamento permitem a adaptação a distúrbios nos casos estudados.

Com relação ao que aponta Williamson (1975, p. 257), no caso A3 o acompanhamento das tendências através de hierarquia possivelmente torna a racionalidade menos limitada. No tocante ao oportunismo da rede e da quasi-hierarquia, isto foi verificado no caso A1 e o entrevistado mencionou que, de fato, esta é uma preocupação que é administrada pela organização. No caso C1 o oportunismo também foi mencionado, mas a ocorrência não foi qualificada de grave. Na verdade, nos casos A1 e A2, houve indicações que certas questões são resolvidas quase que por coerção dos parceiros pela empresa estudada. No caso A1, a assimetria da informação é constrangida pela contratação de terceiros que efetuam auditoria de números e processos operacionais.

Nos casos estudados, mesmo nas empresas A2 e A3, as transações não são altamente padronizadas. Portanto, de acordo com Williamson (1985, p. 72-74) a estrutura de governança deveria ser especializada. Não se pode falar aqui também em transações repetitivas, o que confirma uma das razões pelas quais as transações de mercado não são encontradas.

No caso A1, há convergência com o que argumenta Williamson (1985, p. 90). A alteração na estrutura para franquias de desenvolvimento e distribuição está relacionada ao aperfeiçoamento dos incentivos. No caso para quasi-hierarquia. Também no caso A2, na distribuição, esta é apenas 50\% integrada verticalmente, pois a quasi-hierarquia - que é mais próxima de relações de mercado do que uma estrutura integrada verticalmente - atua no sentido de limitar as distorções da burocracia. A escolha da quasi-hierarquia nos casos A2 e A3 pode estar relacionada à possibilidade de contratos relativamente mais incompletos do que 
uma transação gerenciada como rede ou pelo mercado. Esta questão da maior incompletude possível dos contratos pode estar entre as razões que levaram as empresas B2 e B3 a optarem pela hierarquia. Contudo, sobre este ponto, não foram percebidos contratos completos embora os mesmos não tenham sido nem analisados diretamente e nem discutidos em profundidade nas entrevistas - nos casos A3, C1 e C2, onde há relacionamento do tipo rede.

Foi percebida a existência de contratos relativamente completos nos casos A1 e A2, no gerenciamento quasi-hierarquia. Embora de novo, estes contratos não foram avaliados diretamente e nem discutidos em profundidade.

No caso A3, como indicam Rugman e D’Cruz (2000, p. 89-90), os entrevistados declararam que a empresa procura manter um campo competitivo interno. Este procedimento faz todo o sentido, dada a opção da empresa pela hierarquia. Trata-se de uma forma de evitar capturas de renda indesejadas. É possível que isto ocorresse no caso A1. Também explica mais uma vez a opção do caso A2 por repartir a distribuição entre hierarquia e quasi-hierarquia. No entanto, no caso A3, a opção pela rede no desenvolvimento de produtos e na fabricação não pode ser explicada por estas razões. A explicação é a concentração de capacitação para desenvolver produto sofisticado e de fabricação a custos baixos naquele continente. Nos casos B1, C1 e C3, as relações gerenciadas como redes não são de mercado pela pouca padronização da operação. Conforme explicam Humphrey e Schmitz (2004, p. 362-363), nestes dois casos e principalmente no caso B3, pode ser verificada a existência de competências complementares. Contudo, no caso C1 e C2, o produto parece estar no seu estágio inicial, ou pelo menos não é maduro, e a relação tipo rede surge para facilitar a relação da empresa com os usuários, já que é economicamente inviável a hierarquia nestas situações. A inexistência de relações de mercado pode confirmar o que sugere Kaplinsky (2000, p. 140), que estas relações estão confinadas aos produtos padronizados, que trazem baixas rendas.

Esta questão do risco mencionada por Humphrey e Schmitz (2002, p. 24-27) foi mencionada pela empresa B3. Os entrevistados declararam que quanto mais detalhados os pedidos de cotação (RFPs, Requests for Proposal, do inglês), menor o risco de prejuízos. É certo que na literatura é mencionado outro tipo de risco, o do comprador sofrer prejuízos, contudo se trata de uma outra perspectiva do mesmo fenômeno. A hierarquia, por sua vez, possibilita especificação total dos parâmetros. Portanto, em um negócio de margens baixas como são os casos B2 e B3, certas atividades têm incentivos para a integração vertical, como pode ser 
verificado nestas empresas. Os riscos de desempenho incentivam as empresas A1 e A2 a operarem com quasi-hierarquia na distribuição, pelo menos em parte no segundo caso. O mesmo ocorre nestes casos que optaram pela hierarquia (A2) e quasi-hierarquia (A1) no desenvolvimento: é provável que esta opção tenha sido feita para minimizar riscos de desempenho.

A empresa A3, no desenvolvimento de produtos e na fabricação não optou por outra estrutura de governança, diferente da rede, provavelmente pela razão de que seu poder de barganha no exterior ainda não lhe permite fazê-lo. Também, pode avaliar que não seria necessário em função destas capacidades objeto da terceirização serem tão difundidas nos locais onde mantém as parcerias.

Os casos das empresas A3 e B1 se enquadram no que indicam Dedrick e Kraemer (1998, p. 220-221). No caso da A3, a empresa age como compradora e/ou como parceira estratégica na Ásia, vendedora e potencialmente concorrente dos asiáticos nos EUA. Parece propensa a maior êxito, pois os relacionamentos têm um perfil mais flexível. O relacionamento da empresa B1 com o ecossistema do qual faz parte tem um perfil mais flexível.

Com relação aos fatores propostos por Schoemaker (1990, p. 1179-1181) para criação da renda, podem ser feitos os seguintes comentários:

- $\quad$ As estruturas montadas pelas empresas A1 e A3 possivelmente tem como origem a criatividade.

- $\quad$ A empresa B1, na sua busca pelo próximo ciclo tecnológico e identificação dos nichos e atividades que gerarão mais renda, também pode ser considerada como adepta de atitudes criativas.

- $\quad$ As empresas nas quais existe menos espaço para o exercício da criatividade, em função da atividade desenvolvida, são os casos B2 e B3. Isto se deve ao foco na produtividade necessário nesta atividade. Contudo, mesmo com este constrangimento, a empresa B2 surpreendeu com relatos de como é realizada a entrada em novos mercados no exterior. - Q Quanto às assimetrias informacionais, a empresa A3 obtém vantagem neste quesito, frente a seus concorrentes, com o investimento realizado nos escritórios próprios no exterior. Estes escritórios têm como objetivo manter a empresa alinhada com o estado da arte da atividade nos principais centros. 
- $\quad$ Também se pode falar na existência de assimetrias de recursos. O fluxo de recursos é menos volátil para as empresas de capital aberto, A1, A2 e A3. As empresas B2, B3 e C1 têm divulgado que estão em preparativos para a abertura de capital e se isto realmente ocorrer, também ficarão em vantagem com relação à concorrência.

- $\quad$ A falta de reputação do Brasil como prestador de serviços de TI e produtor de software em nada ajuda as empresas estudadas. Pode-se falar em um aumento do custo de transação em virtude deste fator.

- $\quad$ A atividade é complexa no aspecto tecnológico, em parte, devido ao dinamismo existente. Contudo há outros aspectos que a tornam complexa, como a necessidade de pessoal especializado, em conjunto com a dependência das pessoas na prestação de serviços. Estes aspectos afetam todas as empresas pesquisadas, ainda que em graus diferentes.

- $\quad$ O conhecimento aplicado pelas empresas é altamente específico. Uma evidência é a existência de universidades corporativas em alguns dos casos estudados. Com relação a economias na produção, nos casos B2 e B3, este item é fundamental. Os entrevistados confirmam isto nas suas declarações. Quanto à existência de custos irrecuperáveis, primeiro, na prestação de serviços esta é uma ocorrência comum, devido à intangibilidade.

- $\quad$ Quanto às regras econômicas e legais, estas não têm beneficiado as empresas de TI brasileiras com atividade exportadora. Os entrevistados comentam este ponto e há na literatura econômica fundamento para tal observação: a boa prática econômica recomenda que não se taxe exportação. Como boa parte dos países do mundo evita esta situação, os exportadores brasileiros ficam em desvantagem competitiva.

Dos fatores listados, o que pode ser notado é que, de forma geral, aqueles que dependem do ambiente ou de regras econômicas e legais contribuem para o aumento do custo de transação. As empresas estudadas têm desenvolvido iniciativas que, ao contrário, contribuem para a diminuição do custo de transação. Contudo, não é possível uma estimativa de valores em uma direção e em outra, de forma a se obter o resultado final da ação destas duas forças.

No que se refere à velocidade das inovações de produto, mercado e organizacionais, sobre os casos estudados, cabem as seguintes observações:

- $\quad$ A assimetria informacional gerada pela empresa A3 tem como conseqüência a inovação de produto. 
- $\quad$ A menor volatilidade de recursos resultante da assimetria pode levar à diminuição do custo de transação pela possibilidade de planejamento de prazo mais longo e menor interrupção das atividades desenvolvidas em algumas das estudadas.

- $\quad$ A pouca reputação do Brasil na atividade de TI levou algumas das empresas estudadas ao desenvolvimento de inovações, por exemplo, na abordagem de mercados.

- $\quad$ Há ocorrência de inovação organizacional nas empresas A1, A3 e B1. Neste último caso, a abordagem regional com o ecossistema liderado pela empresa dos EUA pode ser considerada uma inovação na abordagem de mercado.

Com relação ao conceito de determinantes de rendas superiores, proposto por Amit e Schoemaker (1993, p. 38) segue aplicação aos casos estudados.

- $\quad$ Um aspecto notável da estrutura organizacional montada pela empresa A1 é a sua baixa possibilidade de imitação pelos concorrentes, pelo menos no curto prazo. A empresa A1 também logra se apropriar dos resultados, gerados pela maior capacidade empreendedora dos membros da rede.

- $\quad$ O caso A2 desenvolveu sua oferta tendo em mente que o Brasil não iria ser o centro do mundo, portanto sua oferta é complementar ao que existe no mercado. No caso desta empresa, a busca por escala parece convergir com um fator estratégico do setor, que foi mencionado pelos entrevistados na maior parte das empresas estudadas.

- $\quad$ Na empresa A3 também pode ser observada a convergência com fatores estratégicos do setor, no caso, o direcionamento para a Ásia de algumas atividades, notadamente desenvolvimento de produto e fabricação. Além da escala, que esta empresa já possui na sua atividade, agora há a busca por escopo, que pode ser interpretada como convergência com um outro fator estratégico do setor. Também a escassez no mercado de uma oferta completa e testada como a que provê deve ser mencionada.

- $\quad$ No caso B1, pode ser observada a convergência com um fator estratégico do setor na montagem da rede global de fornecedores. Esta solução conta também com a característica da escassez, pelo menos na América Latina. À empresa estudada é possível se apropriar dos resultados da ação.

- $\quad$ A empresa B2, além da convergência com o fator escala, considerado estratégico no setor, pode ser mencionado que é possível se apropriar dos rendimentos gerados por esta característica. O caso B3 é semelhante. 
- $\quad$ O caso C1 está montando uma oferta especializada no setor financeiro, que conta com baixa possibilidade de imitação, pela sua completude. À empresa, é possível se apropriar dos ganhos desta especialização.

- $\quad$ O caso C2 se beneficia da característica da escassez de sua solução em termos nacionais e internacionais.

O quadro 53, que segue, apresenta um resumo das características mais notáveis dos recursos e capacitações das empresas estudadas, que podem contribuir na geração de renda econômica superior.

Quadro 53 - Características dos casos estudados para geração de renda superior

\begin{tabular}{|c|c|}
\hline EMPRESA & PRINCIPAIS CARACTERÍSTICAS OBSERVADAS \\
\hline A1 & Baixa possibilidade de imitação e apropriabilidade \\
\hline A2 & Complementaridade e convergência com um fator estratégico do setor (escala) \\
\hline A3 & $\begin{array}{c}\text { Convergência com fatores estratégicos do setor (direcionamento para a Ásia de algumas } \\
\text { atividades). Escassez . }\end{array}$ \\
\hline B1 & $\begin{array}{l}\text { Convergência com um fator estratégico do setor (montagem da rede global de fornecedores). } \\
\text { Escassez. Apropriabilidade. }\end{array}$ \\
\hline B2 & Convergência com o fator escala, considerado estratégico no setor. Apropriabilidade. \\
\hline B3 & Convergência com o fator escala, considerado estratégico no setor. Apropriabilidade. \\
\hline C1 & Baixa possibilidade de imitação, pela sua completude. Apropriabilidade. \\
\hline C2 & Escassez. \\
\hline
\end{tabular}

FONTE: AUTOR, 2008, com conceitos de AMIT; SCHOEMAKER, 1993, p. 38, aplicados aos casos estudados (informações obtidas na pesquisa de campo).

As empresas estudadas procuram impedir que as forças competitivas que fazem as rendas superiores tenderem a zero atuem, das formas que seguem:

- $\quad$ Empresa A1. Atuação preferencialmente na camada de maior complexidade, que possibilita renda alta. Movimentação permanente para atividades que envolvam inteligência, pois aquelas que são processo são mais limitadas em termos de obtenção de renda. Portanto, a empresa deve equilibrar seu portfólio para não ficar baseada em preço. Na cadeia do software, os papéis mais bem remunerados estão na consultoria de valor agregado. Nesta atividade, é possível a precificação - o faturamento - com base no ganho do cliente. Quanto mais próximo do core business do cliente, 
maior a possibilidade de renda alta. De forma geral, o segmento das grandes empresas possibilita renda crescente, pois o comprador vê valor na oferta da empresa.

- $\quad$ Empresa A2. A empresa entende que o segmento das PMEs possui renda e retorno crescentes devido às barreiras a entrada existentes e às economias de escala possíveis. Através da maior flexibilidade de seu produto - de forma a aproveitar investimentos já feitos pelas empresas compradoras - que seja possível obter renda mais alta. A proximidade com os clientes-alvo e a reputação que a empresa declara ter conquistado junto ao segmento das PMEs são o que impede que as rendas superiores tendam a zero.

- $\quad$ Empresa A3. Privilegia a velocidade, a atuação cuidadosa com os canais e a gestão para impedir que as forças que fazem as rendas superiores tenderem a zero atuem.

- $\quad$ Empresa B1. Há esforço grande de identificação de nichos onde se pode obter maior renda. A atividade de tecnologia se desenvolve em ciclos e a empresa tenta antecipar o que vai ocorrer três ou quatro anos à frente.

- $\quad$ Empresa B2. Melhor preparação dos profissionais para competir nos segmentos que oferecem renda mais alta.

- $\quad$ Empresa B3. A renda superior é obtida através do fornecimento de soluções completas. Abordagem de portfólio. Há serviços nos quais as margens são baixas, mas que permitem à empresa estudada vender serviços que possibilitam renda superior. Estes produtos de margens menores também são importantes para manter a concorrência afastada do comprador. Esta iniciativa contribui para impedir que as forças competitivas que fazem as rendas superiores tenderem a zero atuem. Estas iniciativas são importantes para a concorrência não conseguir obter a escala que é necessária para competir na atividade. Segmento alvo da organização, as grandes empresas, por comprar soluções sofisticadas e soluções padrões em grande volume, possibilita renda crescente.

- $\quad$ Empresa C1. Completude da oferta de produtos atualizados tecnologicamente, com foco em um segmento que é grande comprador de soluções sofisticadas, pois depende delas para sua operação. As ações da empresa no sentido de impedir que as forças competitivas atuem para fazer tender que as rendas superiores tendam a zero são: (1) Atualização tecnológica. (2) Busca de escala e escopo para diluir custos de desenvolvimento e fixos. (3) Relacionamento próximo com clientes.

- $\quad$ Empresa C2. Atuação focada em segmentos de mercado, como o financeiro e produtos muito específicos como o de gerenciamento de documentos. A empresa também atua no segmento alvo de forma diferente dos demais concorrentes, isto é com mais flexibilidade. 
É importante o fato da solução da empresa estudada ser completa, em comparação com as demais soluções existentes no mercado. Criação de novos produtos, com a já citada Diretoria de Tecnologia e Novos Produtos e também com o foco nos funcionários através de ações que envolvem treinamento e alinhamento de interesses. Na criação da diretoria recém constituída, se pode falar em tentativa de criação de novos fluxos de rendas.

O que foi observado nos casos estudados é que a renda derivada da tecnologia é um fenômeno a cada dia mais passageiro. As empresas estudadas buscam rendas de outras formas. Os casos A2, B2, B3 e C2 chamaram a atenção pelo cuidado com a gestão de pessoas. Cuidado nem sempre significa só tratar bem. No caso B3, a gestão de pessoas está direcionada, entre outros aspectos, a manter um campo competitivo dentro da organização. Os casos A1, A3 e B1 obtêm renda superior com formas superiores de organização. A empresa C2 desenvolveu um relacionamento superior com o fornecedor de equipamentos líder da cadeia. É quase redundante mencionar os casos B2 e B3, que desenvolveram relacionamentos superiores com grandes empresas para obtenção de renda superior. Algumas empresas estudadas construíram ou estão ativamente tentando construir barreiras à entrada de concorrentes através da escala. Podem ser mencionados os casos A2, A3, B2 e B3. Em todos os casos deve ser feito um alerta: se as rendas são dinâmicas, no setor de TI este aspecto é ainda mais saliente.

As empresas estudadas, além de sua própria estratégia, no caso das que são de porte maior, também se busca influenciar as mudanças no ambiente. Uma evidência é a associação de classe, na verdade há mais do que, que tem procurado influenciar as ações do governo, em alguns casos com sucesso. De acordo com Govindarajan e Gupta (2001, p. 16 e p. 136), esta é uma escolha crucial. A consideração do exterior na estratégia foi verificada em todos os casos estudados, mas a atitude empresarial global foi verificada no caso A3. Aliás, este é um caso que se pode chamar de internacionalização precoce, nos termos definidos por Jones (2002, p. 593). O que se verificou na empresa $A 3$ foi a internacionalização engendrada a partir do intento estratégico.

Em termos de estratégia global, empresas como a A1, A2, A3 e B1 a baseiam na flexibilidade. As três primeiras optaram por desenvolvimento no exterior, sem ficarem presas a ativos já constituídos no Brasil para esta atividade. O mesmo se pode dizer da empresa B1, com sua operação no ecossistema da empresa dos EUA. Estas empresas e a C1 convergem com o que indicam Porter e Wayland (1995, p. 90) em termos de estratégia global: mostraram 
capacidade de evoluir. A empresa C2 está a caminho de fazê-lo. A empresa B3 também, mas sua atuação internacional ainda deixa a desejar pelo seu porte.

\subsection{Classificação dos casos estudados}

Conforme apresentado no capítulo 4 deste trabalho, os casos estudados são classificados em relação à sofisticação e pró atividade de suas estratégias, e quanto às limitações e possibilidades de obtenção de rendimentos econômicos superiores. Em seguida são apresentados os resultados desta classificação (QUADROS, 54, 55, 56, 57 e 58).

\section{Quadro 54 - Classificação dos casos estudados quanto à sofisticação da estratégia empresarial}

\begin{tabular}{|l|l|l|l|l|l|l|l|l|}
\hline \multicolumn{1}{|c|}{$\begin{array}{l}\text { INDICADORES DA SOFISTICAÇÃo } \\
\text { DA ESTRATÉGIA EMPRESARIAL }\end{array}$} & A1 & A2 & A3 & B1 & B2 & B3 & C1 & C2 \\
\hline Participação da empresa em mais de uma cadeia. & 5 & 4 & 6 & 3 & 3 & 2 & 3 & 3 \\
\hline $\begin{array}{l}\text { Importância conferida aos resultados de longo prazo. } \\
\text { Grau em que se contempla o envolvimento na } \\
\text { coordenação de processos complexos de produção e } \\
\text { distribuição. }\end{array}$ & 4 & 5 & 6 & 5 & 3 & 2 & 4 & 4 \\
\hline $\begin{array}{l}\text { Grau de consciência quanto à necessidade de aprender. } \\
\text { Importância conferida ao aprimoramento contínuo. }\end{array}$ & 5 & 4 & 5 & 6 & 2 & 3 & 3 & 3 \\
\hline $\begin{array}{l}\text { Grau em que as estratégias contemplam o item inovação. } \\
\text { POR CADA CASO ESTUDADO }\end{array}$ & 5 & 4 & 6 & 6 & 2 & 3 & 3 & 3 \\
\hline $\begin{array}{l}\text { Grau e formas de internacionalização contemplada pela } \\
\text { estratégia empresarial. }\end{array}$ & 4 & 4 & 6 & 5 & 4 & 2 & 4 & 3 \\
\hline
\end{tabular}


A classificação foi efetuada com base nas informações (capítulo 4) e julgamentos do autor (capítulo 5, item 5.1) apresentados. O número 1 significa que o grau de sofisticação e pró atividade da estratégia empresarial é muito baixo ou muito pequeno. Já o número 6 significa que o grau de sofisticação e pró atividade da estratégia empresarial é muito alto ou muito grande. Portanto, com base na pontuação do quadro 54, segue a classificação dos casos estudados quanto à sofisticação da estratégia empresarial ${ }^{7}$ :

- $\quad$ Caso A1: 34 pontos. Grau alto de sofisticação da estratégia empresarial.

- $\quad$ Caso A2: 29 pontos. Grau discretamente alto de sofisticação da estratégia empresarial.

- $\quad$ Caso A3: 41 pontos. Grau muito alto de sofisticação da estratégia empresarial.

- $\quad$ Caso B1: 37 pontos. Grau muito alto de sofisticação da estratégia empresarial.

- $\quad$ Caso B2: 20 pontos. Grau discretamente baixo de sofisticação da estratégia empresarial.

- $\quad$ Caso B3: 20 pontos. Grau discretamente baixo de sofisticação da estratégia empresarial.

- $\quad$ Caso C1: 25 pontos. Grau discretamente alto de sofisticação da estratégia empresarial.

- $\quad$ Caso C2: 24 pontos. Grau discretamente baixo de sofisticação da estratégia empresarial.

\footnotetext{
${ }^{7} 7$ a 12 pontos: Muito baixo; 13 a 18 pontos: Baixo; 19 a 24 pontos: Discretamente baixo; 25 a 30 pontos: Discretamente alto; 31 a 36 pontos: Alto e 37 a 42 pontos: Muito alto.
} 
Quadro 55 - Classificação dos casos estudados quanto às limitações à obtenção de rendimentos econômicos superiores

\begin{tabular}{|c|c|c|c|c|c|c|c|c|}
\hline $\begin{array}{l}\text { INDICADORES DA EXISTÊNCIA } \\
\text { E GRAU DAS LIMITAÇÕES }\end{array}$ & A1 & A2 & A3 & B1 & B2 & B3 & C1 & C2 \\
\hline Estrutura de recompensas. & 5 & 6 & 5 & 3 & 2 & 2 & 4 & 4 \\
\hline $\begin{array}{l}\text { Grau de interesse dos compradores no aperfeiçoamento } \\
\text { competitivo das empresas estudadas, de maneira que } \\
\text { vantagens de alto nível como marcas, maior controle de } \\
\text { canais de distribuição e competências de design possam } \\
\text { ser obtidas. }\end{array}$ & 5 & 6 & 6 & 5 & 4 & 4 & 5 & 5 \\
\hline Grau de concentração no segmento comprador. & 3 & 5 & 5 & 2 & 2 & 2 & 2 & 2 \\
\hline Grau de sucesso de estratégias passadas. & 2 & 1 & 3 & 5 & 4 & 3 & 4 & 5 \\
\hline Capacidade de redesenhar as rotinas da empresa. & 6 & 4 & 5 & 6 & 3 & 5 & 5 & 4 \\
\hline $\begin{array}{l}\text { TOTAL DE PONTOS OBTIDOS } \\
\text { POR CADA CASO ESTUDADO }\end{array}$ & 21 & 22 & 24 & 21 & 15 & 16 & 20 & 20 \\
\hline
\end{tabular}

O número 1 significa muito desfavorável e o número 6 significa muito favorável. Portanto, um número baixo de pontos indica que há muitas limitações à obtenção de rendimentos econômicos superiores. Ao contrário, um número alto de pontos significa poucas limitações à obtenção de rendimentos econômicos superiores. Com base na pontuação do quadro 55, segue a classificação dos casos estudados quanto às limitações à obtenção de rendimentos econômicos superiores ${ }^{8}$ :

- $\quad$ Caso A1: 21 pontos. Discretamente favorável quanto às limitações à obtenção de rendimentos econômicos superiores.

- $\quad$ Caso A2: 22 pontos. Discretamente favorável quanto às limitações à obtenção de rendimentos econômicos superiores.

- $\quad$ Caso A3: 24 pontos. Discretamente favorável quanto às limitações à obtenção de rendimentos econômicos superiores.

\footnotetext{
${ }^{8} 5$ a 9 pontos: Muito desfavorável; 10 a 14 pontos: Desfavorável; 15 a 19 pontos: Discretamente desfavorável; 20 a 24 pontos: Discretamente favorável; 25 a 29 pontos: Favorável e 30 a 35 pontos: Muito favorável.
} 
- C Caso B1: 21 pontos. Discretamente favorável quanto às limitações à obtenção de rendimentos econômicos superiores.

- $\quad$ Caso B2: 15 pontos. Desfavorável quanto às limitações à obtenção de rendimentos econômicos superiores.

- C Caso B3: 16 pontos. Desfavorável quanto às limitações à obtenção de rendimentos econômicos superiores.

- Caso C1: 20 pontos. Discretamente favorável quanto às limitações à obtenção de rendimentos econômicos superiores.

- Caso C2: 20 pontos. Discretamente favorável quanto às limitações à obtenção de rendimentos econômicos superiores. 
Quadro 56 - Classificação dos casos estudados quanto às possibilidades de obtenção de rendimentos econômicos superiores pelos casos estudados

\begin{tabular}{|l|l|l|l|l|l|l|l|l|}
\hline $\begin{array}{c}\text { INDICADORES DAS POSSIBILIDADES } \\
\text { DE OBTENÇÃO DE RENDIMENTOS } \\
\text { ECONÔMICOS SUPERIORES }\end{array}$ & A1 & A2 & A3 & B1 & B2 & B3 & C1 & C2 \\
\hline $\begin{array}{l}\text { Movimentação para segmentos econômicos mais } \\
\text { rentáveis e/ou de maior sofisticação tecnológica e/ou mais } \\
\text { intensivos em capital ou competências. }\end{array}$ & 2 & 4 & 5 & 6 & 3 & 4 & 3 & 3 \\
\hline $\begin{array}{l}\text { Inovação continua nos itens que acima (processo, produto } \\
\text {..) em comparação aos concorrentes. }\end{array}$ & 5 & 4 & 5 & 6 & 2 & 4 & 4 & 4 \\
\hline $\begin{array}{l}\text { Aprendizado recente e possibilidade de ocorrência no } \\
\text { futuro próximo / distante. }\end{array}$ & 5 & 4 & 5 & 6 & 4 & 5 & 4 & 4 \\
\hline $\begin{array}{l}\text { Existência e importância da aquisição de conhecimento } \\
\text { tácito em tempos recentes. }\end{array}$ & 5 & 4 & 6 & 6 & 4 & 3 & 5 & 3 \\
\hline $\begin{array}{l}\text { Trau de aperfeiçoamento competitivo de processo, } \\
\text { produto, funcional e inter-setorial (foco nos três últimos). }\end{array}$ & 4 & 4 & 6 & 5 & 3 & 4 & 4 & 3 \\
\hline $\begin{array}{l}\text { Alterações organizacionais e nas rotinas em tempos } \\
\text { recentes. }\end{array}$ & 5 & 4 & 6 & 5 & 3 & 5 & 5 & 3 \\
\hline $\begin{array}{l}\text { Melhoramentos em itens valorizados pelos compradores, } \\
\text { como por exemplo, qualidade e pontualidade. }\end{array}$ & 5 & 5 & 3 & 5 & 5 & 5 & 4 & 4 \\
\hline & $\mathbf{3 1}$ & $\mathbf{2 9}$ & $\mathbf{3 6}$ & $\mathbf{3 9}$ & $\mathbf{2 4}$ & $\mathbf{3 0}$ & $\mathbf{2 9}$ & $\mathbf{2 4}$ \\
\hline
\end{tabular}

O número 1 significa que as possibilidades de obtenção de rendimentos econômicos superiores pelos casos estudados são muito baixas. Contrariamente, o número 6 significa que as possibilidades de obtenção de rendimentos econômicos superiores pelos casos estudados são muito altas. Portanto, com base na pontuação do quadro 56, segue a classificação dos casos estudados quanto à sofisticação da estratégia empresarial ${ }^{9}$.

- $\quad$ Caso A1: 31 pontos. Possibilidades altas de obtenção de rendimentos econômicos superiores.

\footnotetext{
${ }^{9} 7$ a 12 pontos: Muito baixas; 13 a 18 pontos: Baixas; 19 a 24 pontos: Discretamente baixas; 25 a 30 pontos: Discretamente altas; 31 a 36 pontos: Altas e 37 a 42 pontos: Muito altas.
} 
- $\quad$ Caso A2: 29 pontos. Possibilidades discretamente altas de obtenção de rendimentos econômicos superiores.

- $\quad$ Caso A3: 36 pontos. Possibilidades altas de obtenção de rendimentos econômicos superiores.

- $\quad$ Caso B1: 39 pontos. Possibilidades muito altas de obtenção de rendimentos econômicos superiores.

- $\quad$ Caso B2: 24 pontos. Possibilidades discretamente baixas de obtenção de rendimentos econômicos superiores.

- $\quad$ Caso B3: 30 pontos. Possibilidades discretamente altas de obtenção de rendimentos econômicos superiores.

- $\quad$ Caso C1: 29 pontos. Possibilidades discretamente altas de obtenção de rendimentos econômicos superiores.

- $\quad$ Caso C2: 24 pontos. Possibilidades discretamente baixas de obtenção de rendimentos econômicos superiores.

Em resumo, a pontuação, a classificação e a colocação dos casos estudados quanto à sofisticação da estratégia empresarial, limitações e possibilidades de obtenção de rendimentos econômicos superiores se encontram dispostos a seguir (QUADRO 57). 
Quadro 57 - Resumo geral quanto à sofisticação da estratégia empresarial, limitações e possibilidades de obtenção de renda econômica superior

\begin{tabular}{|c|c|c|c|c|c|c|c|c|c|}
\hline \multirow[b]{2}{*}{ CASO } & \multicolumn{3}{|c|}{$\begin{array}{l}\text { SOFISTICAÇÃO DA } \\
\text { ESTRATÉGIA } \\
\text { EMPRESARIAL }\end{array}$} & \multicolumn{3}{|c|}{$\begin{array}{l}\text { LIMITAÇÕES À OBTENÇÃO } \\
\text { DE RENDIMENTOS } \\
\text { ECONÔMICOS SUPERIORES }\end{array}$} & \multicolumn{3}{|c|}{$\begin{array}{l}\text { POSSIBILIDADES DE } \\
\text { OBTENÇÃO DE } \\
\text { RENDIMENTOS } \\
\text { ECONÔMICOS } \\
\text { SUPERIORES }\end{array}$} \\
\hline & Pontos & Classific. & Coloc. & Pontos & Classific. & Coloc. & Pontos & Classific. & Coloc. \\
\hline A1 & 34 & Alto & $3^{\circ}$ & 21 & $\begin{array}{l}\text { Discreta- } \\
\text { mente } \\
\text { favorável }\end{array}$ & $3^{\circ}$ & 31 & Altas & $3^{\circ}$ \\
\hline A2 & 29 & $\begin{array}{l}\text { Discreta- } \\
\text { mente alto }\end{array}$ & $4^{0}$ & 22 & $\begin{array}{l}\text { Discreta- } \\
\text { mente } \\
\text { favorável }\end{array}$ & $2^{o}$ & 29 & $\begin{array}{l}\text { Discreta- } \\
\text { mente } \\
\text { altas }\end{array}$ & $5^{\circ}$ \\
\hline A3 & 41 & Muito alto & $1^{\circ}$ & 24 & $\begin{array}{l}\text { Discreta- } \\
\text { mente } \\
\text { favorável }\end{array}$ & $1^{o}$ & 36 & Altas & $2^{o}$ \\
\hline B1 & 37 & Muito alto & $2^{o}$ & 21 & $\begin{array}{l}\text { Discreta- } \\
\text { mente } \\
\text { favorável }\end{array}$ & $3^{\circ}$ & 39 & $\begin{array}{l}\text { Muito } \\
\text { altas }\end{array}$ & $1^{\mathrm{o}}$ \\
\hline B2 & 20 & $\begin{array}{l}\text { Discreta- } \\
\text { mente } \\
\text { baixo } \\
\end{array}$ & $7^{\circ}$ & 15 & Desfavorável & $8^{\circ}$ & 24 & $\begin{array}{l}\text { Discreta- } \\
\text { mente } \\
\text { baixas }\end{array}$ & $7^{\circ}$ \\
\hline B3 & 20 & $\begin{array}{l}\text { Discreta- } \\
\text { mente } \\
\text { baixo }\end{array}$ & $7^{\circ}$ & 16 & Desfavorável & 70 & 30 & $\begin{array}{l}\text { Discreta- } \\
\text { mente } \\
\text { altas }\end{array}$ & $4^{\circ}$ \\
\hline C1 & 25 & $\begin{array}{l}\text { Discreta- } \\
\text { mente alto }\end{array}$ & $5^{\circ}$ & 20 & $\begin{array}{l}\text { Discreta- } \\
\text { mente } \\
\text { favorável }\end{array}$ & $5^{\circ}$ & 29 & $\begin{array}{l}\text { Discreta- } \\
\text { mente } \\
\text { altas } \\
\end{array}$ & $5^{\circ}$ \\
\hline C2 & 24 & $\begin{array}{l}\text { Discreta- } \\
\text { mente } \\
\text { baixo }\end{array}$ & $6^{\circ}$ & 20 & $\begin{array}{l}\text { Discreta- } \\
\text { mente } \\
\text { favorável }\end{array}$ & $5^{\circ}$ & 24 & $\begin{array}{l}\text { Discreta- } \\
\text { mente } \\
\text { baixas }\end{array}$ & $7^{0}$ \\
\hline
\end{tabular}

Segue a classificação dos casos estudados (QUADRO 58): 
Quadro 58 - Classificação dos casos estudados

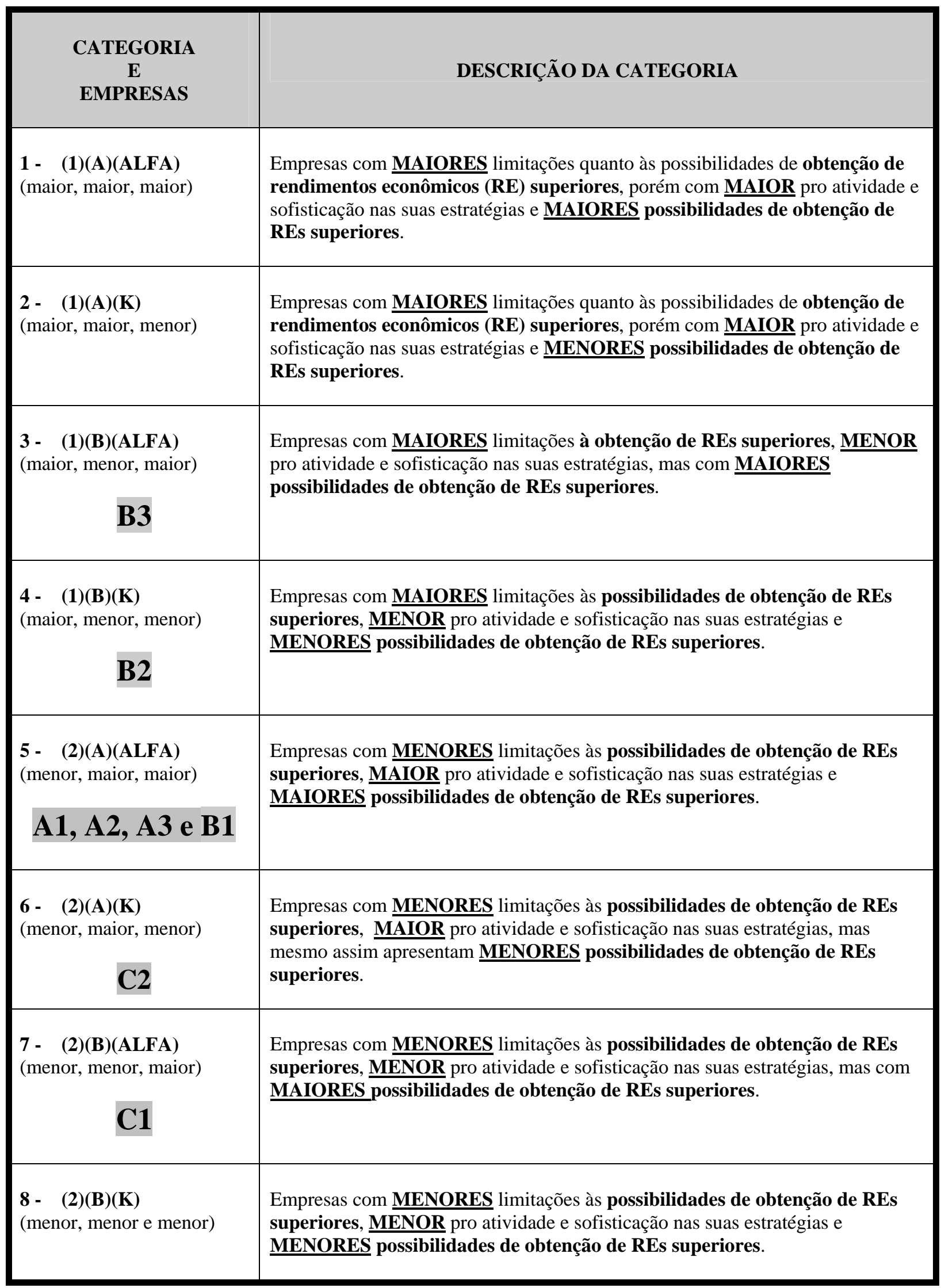


Seguem algumas observações sobre a classificação dos casos estudados:

- $\quad$ A organização A3, em função da estratégia de desenvolvimento de produtos no exterior, fabricação na Ásia para mercados externos e, principalmente, buscar de forma ativa a completude de sua solução, o que a levou ao aperfeiçoamento competitivo, obteve a pontuação mais alta neste aspecto. Deve ser notado que é o único caso de aperfeiçoamento competitivo entre os estudados. A empresa A3 é líder de mercado em automação comercial. Sua inserção internacional, além de adiantada é sofisticada e ocorre há muito tempo. Sua estratégia de completude da oferta pode ser considerada sofisticada, embora não esteja imune a problemas. Há desafios a superar na integração das operações de software, que são reconhecidos e têm sido enfrentados pela organização. Contudo, resolvidas estas questões no curto e médio prazo, sua força competitiva é digna de nota.

- $\quad$ A organização B1 compete com base em uma estratégia sofisticada, de forma a atuar de maneira integrada na América Latina, o que chamou a atenção. Outro fator ainda mais notável é a abordagem da empresa de estar permanentemente investigando o próximo ciclo da tecnologia para se posicionar nos segmentos que possibilitam renda mais alta.

- $\quad$ As organizações B2 e B3, embora bem sucedidas até o momento, enfrentam constrangimentos para sua inserção internacional. Além do custo da mão-de-obra no Brasil, o foco destas empresas em produtos menos sofisticados em conhecimento, principalmente a B2, contribuiu para esta classificação. No caso da B3 este fator está atenuado, pois a empresa tem buscado atuar com produtos mais sofisticados. Contudo, o fato desta organização ter suas vendas muito concentradas em poucos clientes (10 maiores com $60 \%$ do total) e a pequena inserção internacional contribuíram para esta classificação. No caso B2, embora a inserção internacional seja notável, visto que está avançada e a empresa enfrenta maiores limitações à obtenção de rendas econômicas superiores há dúvidas quanto à obtenção de renda econômica superior nos próximos anos. Também pesa para esta avaliação o fato de não ter sido observada nenhuma estratégia notável para superar estes desafios. Estes julgamentos foram confirmados por um crescimento baixo para o padrão dos casos estudados, ainda que acima da movimentação financeira em TI no Brasil, da mesma forma que todos os demais participantes deste trabalho.

- $\quad$ A empresa A1, embora tenha se destacado com a reorganização implementada a partir de 1999, enfrenta concorrentes poderosos. Mesmo assim, o estímulo ao comportamento empreendedor para os participantes da rede da empresa traz perspectivas favoráveis. 
- $\quad$ A organização C1, com sua limitação inicial de escala, têm logrado superar esta limitação através de uma série de fusões e aquisições. Para evitar a perda de foco e de capital intelectual em uma atividade tão especializada, optou pela organização em unidades de negócios. Contudo, a grande e crescente concentração do setor financeiro, segmento foco da organização contribui para a classificação quanto às limitações à obtenção de rendimentos econômicos superiores. O crescimento obtido nas vendas do ano de 2007, sobre 2006, impressiona, pois embora possa variar dependendo do critério utilizado, está no intervalo entre 35 e 75\%. No entanto, ainda há desafios a superar: atingir com consistência uma escala viável e consolidar a estrutura criada. Um número maior de êxitos na atuação internacional também faz parte do rol de desafios desta organização.

- $\quad$ A empresa $\mathbf{C 2}$ desenvolveu uma solução, que segundo declarações de seus executivos, é única em termos de Brasil e uma das poucas no mundo. A empresa mais recentemente desenvolveu uma estratégia de alcance temporal mais longo para enfrentar as questões importantes que enfrenta: só conta com dois produtos em seu portfólio, sendo que um deles só é comercializável no mercado local. O segundo produto é comercializado internacionalmente, agora em um segundo país, localizado no continente europeu. Preocupa o porte desta empresa, dada a ênfase na escala que os entrevistados nas demais estudadas colocaram. Também preocupa o fato da organização ter demorado demais para reagir e preparar uma estratégia de atuação para os próximos anos.

- $\quad$ A empresa $\mathbf{A 2}$ atravessa um momento excepcional: seus resultados são melhores a cada trimestre e a empresa deve continuar se beneficiando da difusão da tecnologia para as PMEs. As indicações obtidas sinalizam para uma organização bem estruturada e preparada. Seu porte é notável em relação aos demais, fruto de um planejado programa de aquisições implementado nos últimos anos. Contudo, não ficou claro se além de obter os benefícios de uma estratégia inteligente no passado, há algo de semelhante poder em gestação para os próximos anos. 


\section{Capítulo 6 - CONCLUSÃO}

Com relação às estratégias que foram desenvolvidas pelas empresas estudadas para que a conexão nas GVCs lhes possibilitasse maior renda econômica, em resumo, pode ser destacado o que segue:

- $\quad$ Há desenvolvimento de produto no Brasil e no exterior. Também ocorre desta atividade ser terceirizada ou estar integrada. A empresa A3, que tem produtos desenvolvidos não só por terceiros, mas também no exterior, faz deste aspecto uma vantagem competitiva. Os casos A1, A2, B2 e C1 desenvolvem parte dos produtos no exterior. No caso B3 também ocorre para uma linha de produtos. Algumas vezes são utilizados terceiros. No caso A1, o terceiro opera sob a forma de quasi-hierarquia.

- $\quad$ Embora nenhuma das empresas estudadas esteja voltada para atuação no mercado de consumo, no qual a atividade de marketing é mais facilmente reconhecida como importante, seis, dentre as oito empresas estudadas reconhecem a relevância deste aspecto para a operação. A maioria (A1, A2, A3, B2, B3) mencionou investimentos em comunicação no exterior.

- $\quad$ A maior parte dos casos atua com um modelo de atuação que lhes confere flexibilidade alta (A1, A3 e B1) ou média (C1 e C2).

- $\quad$ A atuação em rede foi verificada na organização B1. A estratégia desenvolvida por esta empresa lhe permitiu desenvolver novas formas de atuação, produtos, parceiros e mercados de forma permanente.

- $\quad$ O caso A1 é interessante, pois foi desenvolvida uma estratégia de atuação, que levou a empresa a implementar um sistema de franquias para desenvolvimento e para distribuição.

Este sistema estimula o comportamento empreendedor dos franqueados.

- $\quad$ Nas GVCs nas quais as empresas participam, há cadeias governadas pelas empresas de origem brasileira estudada em três casos (A1, A2 e A3). Em outros três casos (B2, B3 e C1), a cadeia é governada pelos compradores. Nos dois casos restantes (B1 e C2), a cadeia é governada por fabricantes de equipamentos, localizados em países desenvolvidos. Governar a cadeia é uma estratégia poderosa para a obtenção de renda superior. As empresas estudadas que não se encontram nesta posição deveriam avaliar este ponto. A empresa B1, ciente da fragilidade de sua posição, procura minimizá-la com o desenvolvimento de um planejamento para identificar os próximos ciclos da tecnologia e em que posição deve estar para auferir maior renda econômica. 
- $\quad$ As estratégias desenvolvidas devem considerar a inovação nos aspectos

organizacionais, pois segundo vários entrevistados, o aspecto tecnológico tem influência cada vez menor na atividade de TI.

- $\quad$ As estratégias desenvolvidas pelas empresas B2 e B3 as levam a desenvolver atividades que propiciam baixas rendas. No caso da empresa B3, esta questão é reconhecida pelos executivos da organização entrevistados. Pode haver nestes dois casos atividade crescente e rendas decrescentes. A empresa B3 procura desenvolver produtos mais sofisticados, de maior complexidade. Para evitar esta situação, a empresa A1 também adota este procedimento e associa este perfil de produto à obtenção de renda mais alta. Produtos sofisticados também são do interesse das empresas C1 e C2, contudo, a esta última, principalmente, falta escala e escopo. As indicações são que, para a obtenção de rendas mais altas, o desafio da sofisticação / complexidade dos produtos deve ser perseguido sem que sejam deixadas de lado as considerações de escala.

- $\quad$ Além da questão da governança, que em algumas situações pode estar fora do controle da organização, as empresas estudadas devem estar atentas ao ciclo tecnológico para preparar seu posicionamento futuro, como ocorre no caso B1.

- $\quad$ A busca de segmentos menos expostos à competição, como é o caso das empresas A2 e A3, é um caminho que deve ser avaliado, pois parece atraente. A empresa A3 também optou por oferecer uma solução completa. Além de barrar a entrada de concorrentes, há ganhos derivados do aumento do escopo e da escala. A empresa B3 já percebeu que este pode ser um caminho proveitoso para a obtenção de maior renda econômica e trabalha ativamente nesta direção.

- $\quad$ Nos casos A2 e A3, pode-se há uma característica comum que é o direcionamento para PMEs. Este mercado é mais fragmentado do que o segmento composto pelas organizações de grande porte, o que permite às estudadas a governança da cadeia. Uma outra vantagem deste segmento é a maior proteção à competição. As razões de o segmento estar protegido da competição são: o desinteresse e a falta de capacitação das grandes multinacionais concorrentes para operar neste segmento em prazos curtos. A empresa A3 foi a única da amostra em que ocorreu aperfeiçoamento competitivo. Embora não se possa tecer afirmações definitivas sobre a relação entre a fragmentação do segmento-alvo e a ocorrência de aperfeiçoamento competitivo, as indicações encontradas sugerem um exame mais cuidadoso deste aspecto. 
Quanto à relação apresentada no capítulo 1, que foi sintetizada na ilustração 3, concluiu-se que:

O construto das cadeias de valor global pode ser utilizado devido à seqüência de atividades e ao relacionamento internacional das empresas estudadas, com a coordenação de sistemas dispersos de produção e distribuição através de redes de empresas, sem que haja necessariamente ligações societárias entre estas. (KAPLINSKY; MORRIS, 2003, p. 4-6; HUMPHREY, 2003, p. 10).

- $\quad$ Como indicam alguns dos autores da revisão da literatura, há associação entre necessidade de adaptabilidade e reatividade e forma organizacional.

- $\quad$ O desenvolvimento de produtos, sua produção e atividades de marketing, em todos os casos estudados, envolve uma cadeia de atividades distribuída entre diferentes empresas. (DOLAN; HUMPHREY, 2000, p. 148).

- $\quad$ De fato, houve casos em que as atividades de alto risco e baixos retornos foram transferidas a terceiros. (STEINFELD, 2002, p. 6-7).

- $\quad$ Houve aperfeiçoamento funcional em um dos casos estudados, mas diferente do que indica parte da literatura, este evento não ocorreu de forma automática: é um caso no qual a estratégia empresarial foi classificada em um nível de sofisticação muito alto.

- $\quad$ A associação entre governança por terceiros e empresas dos países em desenvolvimento não foi confirmada no estudo. Três das empresas estudadas governam a cadeia. Ao mesmo tempo, também não foi confirmada a associação entre alta sofisticação da estratégia e governança da cadeia. Houve caso em que embora a empresa não governe a cadeia, a sofisticação de sua estratégia foi classificada como muito alta.

- $\quad$ Diferente do que indicam Humphrey e Schmitz (2002, p. 3 e p. 20), o acesso aos mercados dos países desenvolvidos nem sempre dependeu da entrada nas redes de produção das empresas líderes. Em três dos casos, a estudada governa a cadeia.

- $\quad$ As empresas estudadas desenvolveram seus produtos para o mercado local e posteriormente os comercializaram no exterior. (DEDRICK; KRAEMER, 1998, p. 229).

- $\quad$ Como notam Gibbon e Ponte (2005, p. 138), foi verificada em um caso a situação de marginalização competitiva, ou pelo menos tendência a esta situação.

- $\quad$ Na maior parte dos casos estudados foi observada a possibilidade da ocorrência do travamento na posição. (HUMPHREY, 2003, p. 18-19).

- $\quad$ Houve casos de evidência de aperfeiçoamento competitivo fora da esfera produtiva, diferente do que encontraram Schmitz e Knorringa (1999, p. 19-21). 
- Houve convergência com a proposição teórica da ilustração 3, que relaciona sofisticação da estratégia, limitações e possibilidades de obtenção de renda econômica e esta última em quatro dos oito casos estudados.

- $\quad$ Como concluem Gereffi et al (2005, p. 98), há casos em que a coordenação pelos fornecedores ocorre e nestes reside o poder na cadeia.

Com relação às limitações deste trabalho, podem ser destacados os seguintes pontos: - $\quad$ Não houve quantificação da renda obtida pelas empresas. Também se nota a falta de definições operacionais mais precisas sobre este conceito.

- $\quad$ Foram analisadas somente as empresas estudadas. Para conclusões mais robustas sobre as GVCs, precisariam ser estudadas outras empresas das cadeias.

- $\quad$ O exame das ações das empresas estudadas, embora avaliadas de outras formas, dependeu em grande parte dos que os executivos das empresas declararam e do julgamento do autor. Potencialmente, há problemas que podem advir destas circunstâncias, como respostas dissimuladas, direcionamento para respostas politicamente corretas e ocultação de estratégias e planos futuros. Este último caso certamente ocorreu.

- $\quad$ Embora as empresas estudadas compartilhem semelhanças, a qualidade para a comparação de casos depende da homogeneidade da amostra. A homogeneidade completa é pouco provável. Agora há diferenças que devem ser notadas. Por exemplo, em relação ao porte das empresas estudadas. Também em relação à forma jurídica. Três das empresas estudadas já são de capital aberto. Outras três se preparam para trilhar o mesmo caminho. - $\quad$ As questões técnicas dos casos estudados não são objeto do exame deste trabalho, que se concentrou nos aspectos da gestão, especificamente estratégia empresarial, conexão às GVCs, governança destas cadeias e renda. Embora se reconheça a relevância destes aspectos técnicos, que podem mudar a trajetória de um negócio com o perfil dos estudados, estão fora do escopo deste estudo.

Também há um alerta que se faz necessário: este estudo tem propósitos acadêmico-científicos. Sua utilização fora deste contexto não é recomendada e aqueles que o fizerem agem por sua conta e risco.

Com relação a estudos futuros, uma idéia é selecionar alguma ou poucas empresas da amostra e conduzir investigações junto a outros participantes da cadeia. Outra sugestão é selecionar 
empresas semelhantes em outros países e procurar estabelecer comparações sobre suas estratégias e conexões internacionais através de GVCs. Também se pode investigar o agrupamento de empresas que compõem o cluster de franquias de desenvolvimento da empresa A1 e examinar aspectos mais específicos da sua operação. Finalmente, um veio rico para estudos futuros pode estar na investigação das replicações, conforme mencionado no capítulo 3, entre os casos estudados. 


\section{REFERÊNCIAS}

ALBORNOZ, Facundo; YOGUEL, Gabriel. Competitiveness and production networks: the case of the Argentine automotive sector. Industrial and Corporate Change, volume 13, número 4, 2004.

AMBASTHA, Ajitabh; MOMAYA, K. Competitiveness of firms: review of theory, frameworks and models. Singapore Management Review, volume 26; número 1, 2004.

AMIT, Raphael; SCHOEMAKER, Paul J. H.. Strategic assets and organizational rent. Strategic Management Journal, volume 14, número 1, p. 33-46, 1993.

ASSOCIAÇÃO BRASILEIRA DAS EMPRESAS DE SOFTWARE - ABES. Mercado brasileiro de software: panorama e tendências 2007. Disponivel em http://abes.org.br, acesso em 16/10/2007.

BANCO MUNDIAL. Middle-income countries - selected information. Appendix A. Disponível em http://worldbank.com. Acesso em 01/05/2008.

BANCO NACIONAL DE DESENVOLVIMENTO ECONÔMICO E SOCIAL - BNDES. Classificação de porte de empresa. Disponível em

<http://www.bndes.gov.br/clientes/porte/porte.asp>. Acesso em 22/4/2008.

BARNEY, Jay B.. Types of competition and the theory of strategy: toward an integrative framework. The Academy of Management Review, volume 11, número 4, p. 791-800, 1986.

Firm resources and sustained competitive advantage. Journal of Management, volume 17, número 1, p. 99-120, 1991.

BASILE, Roberto; GIUNTA, Anna; NUGENT, Jeffrey B.. The internationalization of small and medium-sized firms in Italy during the 1990s. In PIETROBELLI, Carlo; SVERISSON, Arni (organizadores), Limking local and global economies: ties that bind, London, Routledge, 2004.

BAZAN, Luiza; NAVAS-ALEMÁN Lizbeth. Comparing Chain governance and upgrading patterns in the Sinos Valley, Brazil. Trabalho apresentado no workshop "Local Upgrading of Global Chains” no Institute of Development Studies, University of Sussex, Brighton, Reino UNido, de 14 a 17 de fevereiro de 2001 (versão revisada de julho de 2001).

The underground revolution in the Sinos Valley: a comparison of upgrading in global and national value chains. In SCHMITZ, Hubert organizador), Local Enterprises in the Global Economy: Issues of governance and upgrading, Cheltenham, Edward Elgar Publishing Limited, 2004. 
BELL, Martin; ALBU, Michael. Knowledge Systems and Technological Dynamism in Industrial Clusters in Developing Countries. World Development, volume 27, Número 9, 1999.

BERGER, Suzanne, STURGEON, Timothy, KURZ, Constanze; VOSKAMP, Ulrich e WITTKE, Volker. Globalization, Value Networks and National Models. MIT Industrial Performance Center IPC Globalization Working Paper 99-000, 1999.

BERNARD Andrew B.; JENSEN, J. Bradford. Exceptional Exporter Performance: Cause, Effect or Both. Journal of International Economics, volume 47, p. 1-25, 1999.

BOLSA DE VALORES DE SÃO PAULO - BOVESPA. Disponível em http://bovespa.com.br. Vários acessos em 2005, 2006, 2007 e 2008.

BRADFORD JR. Colin I.. The new paradigm of systemic competitiveness: toward more integrated policies in Latin America. Paris, OCDE, 1994.

BUCKLEY, Peter J.; PASS, Christopher L. e PRESCOTT, Kate. Measures of International Competitiveness: A Critical Survey. Journal of Marketing Management, volume 4, No 2, 1988.

CAMUFFO, Arnaldo; FURLAN, Andrea e GRANDINETTI, Roberto. Knowledge and capabilities in the subcontractor's evolution: the Italian case. MIT-IPC-05-004, Massachussets Institute of Technology, Industrial Performance Center, Working Paper Series, 2005A.

CAMUFFO, Arnaldo; FURLAN, Andrea; ROMANO, Pietro e VINELLI, Andrea. Breathing Shoes and Complementarities: How GEOX has Rejuvenated the Footwear Industry. MITIPC-05-005, Massachussets Institute of Technology, Industrial Performance Center, Working Paper Series, 2005B.

CASSIOLATO, José Eduardo; LASTRES, Helena Maria Martins. Local Systems of Innovation in Mercosur Countries. Industry and Innovation, volume 7, número 1, p. 3353, 2000.

CASTELLANI, Davide. Export behaviour, firm size and productivity growth in Italy. . In PIETROBELLI, Carlo; SVERISSON, Arni (organizadores), Limking local and global economies: ties that bind, London, Routledge, 2004.

CASTRO, Cláudio de Moura. A prática da pesquisa. São Paulo, Mcgraw Hill, 1977.

CONOLLY, Kate Phillips; SULLIVAN, Erin; BRENNAN, Louis; MURRAY, John. International supply chain management: a walk around the elefant. Irish Journal of Management, volume 26, número 1, p. 149, 2005. 
COMISSÃO DE VALORES MOBILIÁRIOS DO BRASIL - CVM. Disponível em http://www.cvm.gov.br. Diversos acessos entre outubro de 2007 e março de 2008.

COOKE, Phillip; MORGAN, Kevin. The associational economy: firms, regions and innovation. London, Oxford University Press, 1998.

DEDRICK, Jason; KRAEMER, Kenneth L.. Asia's computer challenge: threat or opportunity for the United States and the world? New York, Oxford University Press Inc, 1998.

DICKEN, Peter. Global shift. 3a edição, New York, The Guilford Press, 1998.

DICKEN, Peter; KELLY, Phillip; OLDS, Kris; YEUNG, Henry Wai-Chung. Chains and networks, territories and scales: towards a relational framework for analysing the global economy. Global Networks, volume 1, número 2, p. 89-112, 2001.

DOLAN, Catherine; HUMPHREY, John. Governance and trade in fresh vegetables: the impact of UK supermarkets on the African horticulture industry. The Journal of Development Studies, volume. 37, número 2, 2000.

DOSI, Giovanni. Organizational competences, firm size, and the wealth of nations: some comments from a comparative perspective. In: CHANDLER Jr, Alfred D.; AMATORI, Franco and HIKINO, Takashi (Org.). Big Business and the Wealth of Nations. Cambridge, Cambridge University Press, 1997.

DUGUID, Paul. Networks and Knowledge: The Beginning and End of the Port Commodity Chain, 1703-1860. Business History Review, volume 79, número 3, 2005.

DUNNING, John H.. The globalization of business. London, Routledge, 1995.

. Regions, globalization and the knowledge economy: the issues stated. In DUNNING, John. Regions, Globalization and the Knowledge-Based Economy. New York, Oxford University Press, 2000.

EASTON, Geoff; ARAUJO, Luis. Characterizing organizational competences: an industrial networks approach. In SANCHEZ, Ron; HEENE, Aimè; THOMAS, Howard; Dynamics of Competence-Based Competition: Theory and Practice in the New Strategic Management. Exeter, Elsevier, 1996.

ELFRING, Tom; BAVEN, Geert. Spinning-off capabilities: competencedevelopmente in knowledge-intensive services. In SANCHEZ, Ron; HEENE, Aimè; THOMAS, Howard. Dynamics of competence-based competition: theory and practice in the new strategic management. Exeter, Elsevier, 1996.

EISENHARDT, Kathleen. Building theories from case study research. Academy of Management Review, volume 14, número 4, p. 532-550, 1989. 
EZEALA-HARRISON, Fidelis. Theory and policy of international competitiveness. Westport, Praeger Publishers, 1999.

FEAR, Jeffrey R.. Constructing big business: the cultural concept of the firm. In: CHANDLER Jr, Alfred D.; AMATORI, Franco and HIKINO, Takashi (Org.). Big Business and the Wealth of Nations. Cambridge, Cambridge University Press, 1997.

FOSS, Nicolai Juul. Ethics, discovery, and strategy. Journal of Business Ethics, volume 16, número 11, p. 1131, 1997.

FOSS, Nicolai Juul. More on knight and the theory of the firm. Managerial and decision economics, volume 14, número 3, 1993.

FOSS, Nicolai Juul. The emerging knowledge governance approach: challenges and characteristics. Organization, volume 14, número 29, 2007.

FOSS, Nicolai J.; KNUDSEN, Thorbjorn. The resource-based tangle: towards a sustainable explanation of competitive advantage. Managerial and decision economics, volume 24, número 4, p. 291, 2003.

GEREFFI, Gary; HUMPHREY, John; STURGEON, Timothy. The governance of global value chains. Review of International Political Economy, volume 12, número 1, p. 78-104, fevereiro de 2005.

GEREFFI, Gary, KORZENIEWICZ, Miguel e KORZENIEWICZ, Roberto. Introduction: global commodity chains. In GEREFFI, Gary; KORZENIEWICZ, Miguel (Organizadores); Commodity Chains and Global Capitalism; Westport, Praeger, 1994.

GEREFFI, Gary, KORZENIEWICZ, Miguel. Commodity chains and global capitalism. Westport, Praeger, 1994.

GEREFFI, Gary. Global commodity chains: new forms of coordination and control among nations and firms in international industries. Competition \& Change, volume 4, 1996.

Gary. International trade and industrial upgrading in the apparel commodity chain. Journal of International Economics, volume. 48, 1999.

Gary. The global economy: organization, governance, and development. In: SMELSER Neil J; SWEDBERG Richard (Organizadores). The Handbook of Economic Sociology. New York, Princeton University Press e Russell Sage Foundation, 2005. 
Gary. The organization of buyer-driven global commodity chains: how U.S. retailers shape overseas production networks. In GEREFFI, Gary e KORZENIEWICZ, Miguel (Organizadores). Commodity chains and global capitalism; Westport: Praeger, 1994.

Gary. The regional dynamics of global trade: Asian, American, and European models of apparel sourcing. In VELLINGA, Menno (organizador). Latin America in global perspective. Boulder, Westview Press, 2000.

GIBBON, Peter; PONTE, Stefano. Africa, value chains and the global economy. Philadelphia, Temple University Press, 2005.

GIBBON, Peter. Commodities, donors, value-chain analisys and upgrading. Disponível em http://www.ictsd.org/dlogue/2004-07-14/Gibbon.pdf. Acesso em fevereiro de 2006, Paper preparado para UNCTAD, 2003.

Upgrading primary production: a global commodity chain approach. World Development, volume. 29, No 2, 2001.

GIULIANI, Elisa; PIETROBELLI, Carlo; RABELLOTTI, Roberta. Upgrading in global value chains: lessons from Latin American clusters. World Development, volume 33, número 4, p. 549-573, 2005.

GOVINDARAJAN, Vijay; GUPTA, Anil. Global dominance: transforming global presence into global competitive advantage. São Francisco, Jossey-Bass, 2001.

GWYNNE, Robert N.. Clusters and commodity chains: firms responses to neo-liberalism in Latin America. Latin American Research Review, volume 39, número 3, p. 243, 2004.

HAMEL, Gary; PRAHALAD, C. K.. Strategic intent. Harvard Business Review, maiojunho de 1989.

HAMILTON, Gary; FEENSTRA, Robert; PETROVIC, Misha. Demand responsiveness and the emergence of capitalism in East Asia: a reassessment of the "Asian miracle". Paper submitted to the globalization, Employment and Economic Development Workshop, Sloan Workshop Series in Industry Studies, Rockport, Massachusetts, 14-16 de junho de 2004.

HAMMERSLEY, Martyn; GOMM, Roger. Introduction. In: GOMM, Roger; HAMMERSLEY, Martyn; FOSTER, Peter. Case study method, London, Sage Publications, 2000.

HAUGE, Atle. Gatekeepers and knowledge diffusion in the fashion industry. Trabalho apresentado no DRUID-DIME Academy Winter 2006 PhD Conference, 26-28 de janeiro de 2006. 
HENDERSON, Jeffrey. Globalisation and forms of capitalism: conceptualisations and the search for synergies. Competition \& Change, volume 1, 1996.

HUMPHPREY, John; KAPLINSKY, Raphael; SARAPH, Prasad V.. Corporate restructuring: Crompton Greaves and the challenge of globalization. New Delhi, Sage Publications, 1998.

HUMPHPREY, John; MEMEDOVIC, Olga. The Global automotive industry value chain: what prospects for upgrading by developing countries. United Nations Industrial Development Organization, Vienna, 2003.

HUMPHREY, John. Opportunities for SMEs in developing countries to upgrade in a global economy. SEED Working Paper No. 43, Series on Upgrading in Small Enterprise Clusters and Global Value Chains, International Labour Office, International Labour Organization, Geneva, 2003.

HUMPHREY, John; SCHMITZ, Hubert. Chain governance and upgrading: taking stock. In SCHMITZ, Hubert (organizador), Local Enterprises in the Global Economy: Issues of governance and upgrading, Cheltenham, Edward Elgar Publishing Limited, 2004.

. Developing country firms in the world economy: governance and upgrading in global value chains. INEF Report; 2002.

Governance and upgrading: linking industrial cluster and global value chain research. IDS Working Paper No 120, Institute of Development Studies, University of Sussex, Brighton, 2000.

The triple C approach to local industrial policy. World Development, volume 24, número 12, p. 1859-1877, 1996.

HUNTER, Ian. Commodity Chains and Networks in Emerging Markets: New Zealand, 1880-1910. Business History Review, volume 79, número 2, 2005.

INTERNATIONAL DATA CORPORATION - IDC. Latin America predictions 2008. Disponível em http://www.idclatin.com. Acesso em 22/4/2008.

INSTITUTO BRASILEIRO DE GEOGRAFIA E ESTATÍSTICA - IBGE. As micro e pequenas empresas comerciais do Brasil - 2001. Disponível em http://www.ibge.gov.br. Acesso em 22/04/2008. Rio de Janeiro, 2003.

INSTITUTO BRASILEIRO DE GEOGRAFIA E ESTATÍSTICA - IBGE. Classificação nacional de atividades econômicas - CNAE. Disponível em http://www.ibge.gov.br. Acesso em 22/04/2008. Rio de Janeiro, 2007. 
INSTITUTO BRASILEIRO DE GEOGRAFIA E ESTATÍSTICA - IBGE. Estatísticas do cadastro geral de empresas. Disponível em http://www.ibge.gov.br. Acesso em 22/04/2008. Rio de Janeiro, 2007.

JONES, Geoffrey. Business enterprises and global worlds. Enterprise \& Society. Oxford, volume 3, número 4, 2002.

KAPLINSKY, Raphael. Globalisation and unequalisation: what can be learned from value chain analysis? Journal of Development Studies. volume 37, número 2, p. 117-146, 2000.

. Globalization, poverty and inequality. Cambridge, Polity Press, 2005.

KAPLINSKY, Raphael; MEMEDOVIC, Olga; MORRIS, Mike; READMAN, Jeff. The global wood furniture value chain: what prospects for upgrading by developing countries. the case of South Africa. United Nations Industrial Development Organization, Vienna, 2003.

KAPLINSKY, Raphael; MORRIS, Mike. A handbook for value chain research. Disponível em <http://www.ids.ac.uk/ids/global/pdfs/VchNov01.pdf>. Institute of Development Studies (IDS), Brighton, 2003. Acesso em março de 2006.

KILDUFF, Peter. Patterns of strategic adjustment in the US textile and apparel industries since 1979. Journal of Fashion Marketing and Management, volume. 9, No 2, 2005.

KNIGHT, Gary A; CAVUSGIL, S. Tamar. Innovation, organizational capabilities and the born-global firm. Journal of International Business Studies, volume 35, 2004.

KNUTSEN, Hege M.. Industrial development in buyer-driven networks: the garment industry in Vietnam and Sri Lanka. Journal of Economic Geography, volume 4, 2004.

KOGUT, Bruce; ZANDER U.. Knowledge of the firm and the evolutionary theory of the corporation. Journal of International Business Studies, volume 34, 2003.

KOGUT, Bruce. Designing global strategies: comparative and competitive value-added chains. Sloan Management Review, volume 26, número 4, p. 15-28, 1985.

LALL, Sanjaya. Competitveness indices and developing countries: an economic evaluation of the global competitiveness report. World Development, volume 29, número 9, 2001.

LANE, Christel; PROBERT, Jocelyn. Domestic capabilities and global production networks in the clothing industry: a comparison of German and UK firms' strategies. Socio-Economic Review, volume 4, 2006. 
LESTER, Richard. China, America and the global competition for industry. MIT IPC Working Paper 03-007, Industrial Performance Center, Massachusetts Institute of Technology, Cambridge, 2003.

MAITLAND, Elizabeth; RICHARD, Pierre J.. Yesterday's friends, tomorrow's foes? Offshoring, rents and institutional settings. Disponível em: <http://papers.ssrn.com/sol3/papers.cfm?abstract_id=965342 2007>. Acesso em 01/05/2007.

MARCONI, Marina de Andrade; LAKATOS, Eva Maria. Fundamentos de Metodologia Científica. 6a edição. São Paulo, Editora Atlas, 2005.

MASKELL, Peter; MALMBERG, Anders. Localized learning and industrial competitiveness. Cambridge Journal of Economics, volume 23, 1999.

MITCHELL, J. Clyde. Case and situation analysis. In: GOMM, Roger; HAMMERSLEY, Martyn; FOSTER, Peter. Case study method, London,Sage Publications, 2000.

MORGAN, Glenn. The multinational firm: organizing across institutional and national divides. In MORGAN, Glenn; KRISTENSEN, Peer Hull; WHITLEY Richard (Organizadores), The multinational firm: Organizing Across Institutional and National Divides, Oxford, Oxford University Press, 2001.

MYTELKA, Lynn K. Local systems of innovation in a globalized world economy. Industry and Innovation, volume 7, número 1, 2000.

NEIDIK, Binnur. Organizational foundations of export performance: the case of the Turkish apparel industry. Journal of Fashion Marketing and Management, Vol. 8, No 3, 2004.

NELSON, Richard R.. Why do firms differ, and how does it matter? Strategic Management Journal, inverno 1991, volume 12, edição especial, p. 61, 1991.

PALPACUER, Florence. Competence-based strategies and global production networks. a discussion of current changes and their implications for employment. Competition \& Change, volume 4, 2000.

PATTON, Michael Quinn. Qualitative evaluation and research methods. Newbury Park, California, Sage Publications, 1990.

PETERAF, Margaret A.. The cornestones of competitive advantage: A Resource-Based View. Strategic Management Journal, volume 14, número 3, 1993.

PIETROBELLI, Carlo. Industry competitiveness and technological capabilities in Chile, a new tiger from Latin America. New York, St. Martin’s Press, Inc., 1998. 
PONTE, Stefano. Quality conventions and the governance of global value chains. Disponível em http://www.globalvaluechains.org/publications/ponte-conventions.pdf, acesso em setembro de 2006.

PORTER, Michael E. What is strategy? Harvard Business Review, novembro - dezembro de 1996.

PORTER, Michael E; WAYLAND, Rebecca E.. Global competition and the localization of competitive advantage. In THORELLI, Hans B. (organizador), Advances in Strategic Management. Integral Strategy: Concepts and Dynamics, volume 11, Parte A, Greenwich, Connecticut, Jai Press Inc., 1995.

PORTER, Michael E. Vantagem competitiva: criando e sustentando um desempemho superior. 30a. edição, São Paulo, Editora Campus, 1990.

RÄSÄNEN, Keijo; WHIPP, Richard. National business recipes: a sector perspective. In WHITLEY, Richard (Organizador), European Business Systems: Firms and Markets in their National Contexts, Newbury Park, Sage Publications Inc, 1992.

RÉGNIER, Phillppe. The east asian crisis and beyond: new perspectives for linkages between SMEs and TNCs? In PIETROBELLI, Carlo; SVERISSON, Arni (organizadores), Limking local and global economies: ties that bind, London, Routledge, 2004.

ROBERTS, Simon; THOBURN, John T.. Globalization and the South African textiles industry: impacts on firms and workers. Journal of International Development, Vol. 16, No 1, 2004.

RUGMAN, Alan M.; D'CRUZ, Joseph R.. Multinationals as flagship firms: regional business networks. New York, Oxford University Press, 2000.

RUGMAN, Alan M..; D'CRUZ, Joseph; Business Networks for International Competitiveness. Business Quarterly, volume 56, número 4, p. 101-107, 1992.

RUMMELT, Richard P.; SCHENDEL, Dan; TEECE, David J.. Strategic management and economics. Strategic Management Journal, volume 12, número Special Issue: Fundamental Research Issues in Strategy and Economics, Winter 1991.

SCHMITZ, Hubert. From ascribed to earned trust in exporting clusters. Journal of International Economics, Vol. 48, 1999A.

Global competition and local cooperation: success and failure in the Sinos Valley, Brazil. World Development, Vol. 27, No 9, 1999B. 
SCHMITZ, Hubert; KNORRINGA, Peter. Learning from global buyers. IDS Working Paper 100, 1999. Disponível em http://www.ntd.co.uk/idsbookshop/details.asp?id=513, acesso em 03/10/2006.

SCHMITZ, Hubert; MUSYCK, Bernard. Industrial districts in Europe: policy lessons for developing countries. World Development, Vol. 22, No 6, 1994.

SCHOEMAKER, Paul J. H.. Strategy, complexity and economic rent. Management Science, volume 36, número 10, p. 1178, 1990.

SCHOFIELD, Janet Ward. Increasing the generalizability of qualitative research. In: Case study method, GOMM, Roger; HAMMERSLEY, Martyn; FOSTER, Peter. London, Sage Publications, 2000.

SPENER, David; GEREFFI, Gary: BAIR, Jeniffer. Introduction: The apparel industry and North American economic integration. In: GEREFFI, Gary; SPENER David; BAIR Jennifer (Organizadores). Free Trade and Uneven Development - The North American Apparel Industry after NAFTA, Philadelphia, Temple University Press, 2002.

STAKE, Robert E.. The art of case study research. Thousand Oaks, California, Sage Publications, 1995.

STEINFELD, Edward S.. Chinese enterprise development and the challenge of global integration. MIT IPC Working Paper 02-004, Industrial Performance Center, Massachusetts Institute of Technology, Cambridge, MA 02139, 2002.

STURGEON, Timothy J.; FLORIDA, Richard. Globalization and jobs in the automotive industry. MIT IPC Globalization Working Paper 01-003, Industrial Performance Center, A Study by Carnegie Mellon University e The Massachusetts Institute of Technology, 2000; Report to the A.P. Sloan Foundation, posted as MIT IPC Working Paper 01-002. Disponível em http://web.mit.edu/ipc/www/publications.html.. Acesso em 23/01/2006.

STURGEON, Timothy J.. Exploring the risks of value chain modularity: electronics outsourcing during the industry cycle of 1992-2002. MIT IPC Working Paper 03-003, Industrial Performance Center, Massachusetts Institute of Technology, 2003.

How we define value chains and production networks? MIT IPC Working Paper 00-010, Industrial Performance Center, Massachusetts Institute of Technology, 2000.

. Modular production networks: a new American model of industrial organization. Industrial and Corporate Change, volume 11, número 3, p. 451-496, 2002.

TEECE, David J.; PISANO, Gary; SHUEN, Amy. Dynamic capabilities and strategic management. Strategic Management Journal, volume 18, número 7, p. 509-533, 1997. 
VELLINGA, Menno. The dialectics of globalization: internationalization, regionalization and subregional response. In: VELLINGA, Menno (organizador). Latin America in global perspective, Boulder, Westview Press, 2000.

WHITLEY, Richard. Business systems and global commodity chains: competing or complementary forms of economic organization? Competition \& Change, Vol. 1, 1996.

WILLIAMSON, Oliver E.. Markets and hierarchies: analysis and antitrust implication. New York, The Free Press, 1975.

Oliver E.. The economic institutions of capitalism. Firms, markets and relational contracting. New York, The Free Press, 1985.

Oliver E.. Comparative economic organization: the analysis of discrete structural alternatives. Administrative Science Quarterly, volume 36, número 2, p. 269, 1991A.

Oliver E.. Strategizing, economizing and the economic organization. Strategic Management Journal, volume 12, p. 75, 1991B.

1996.

Oliver E.. The mechanisms of governance. New York, Oxford University Press,

, Oliver E.. The theory of the firm as governance structure: from choice to contract. The Journal of Economic Perspectives, volume 16, número 3, p. 171, 2002.

WORTZEL, Lawrence e WORTZEL, Heidi Vernon. Export marketing strategies for NIC and LDC-based firms. Columbia Journal of World Business, 1981.

YIN, Robert K.. Case study research: design and methods. 2a edição, Thousand Oaks, California, Sage Publications, 1994. 


\section{APÊNDICE 1 - INSTRUMENTO DE PESQUISA}

\section{Caracterização do setor e da empresa}

\subsection{Ambiente e mercado.}

- $\quad$ Histórico do setor de Tecnologia da Informação (TI) brasileiro. Localização da atividade de TI. Características das transações de TI quanto à padronização e repetição. Evolução no sentido de produtos mais diferenciados? Como a empresa evoluiu dentro desse contexto histórico. Evidências da capacidade de evoluir. Dependência do passado, como o passado constrange o futuro.

- $\quad$ Descrição de mudanças no ambiente de mercado de TI. Avaliação da empresa sobre estabilidade do mercado em que atua (alta, média ou baixa). Elaborar. Confirma que a rapidez e a flexibilidade necessárias para competir em TI na atualidade tendem a favorecer as empresas menores? Elaborar sobre o tema.

- $\quad$ Complexidade do ambiente e instabilidade. Regras econômicas, legais, sociais e pessoais. Necessidade de certificação dos produtos quanto à segurança, condições de trabalho e padrões ambientais. Velocidade da inovação.

- $\quad$ Níveis de competição nos segmentos populares? Dá para não atuar nestes segmentos?

- $\quad$ Há algum exemplo onde a empresa criou um novo mercado? Exemplo de aproveitamento de mercado criado pelos outros?

- $\quad$ Investigar a utilização de novas tecnologias, novas formas organizacionais e novas estratégias de produto que tenham alterado os ambientes competitivos de seus respectivos mercados. Evidências de que isto tenha ocorrido.

- $\quad$ Investigar se o Brasil possui vantagens comparativas em TI.

Onde acha que a cadeia de valor adicionado da atividade de TI deve ser desmembrada em termos internacionais?

- Consegue identificar diferenças tecnológicas entre empresas do Brasil e de outros países no setor?

\subsection{Segmento foco da atuação.}

- $\quad$ Segmento foco da atuação. Como pode afirmar que as características do segmento estão alinhadas as suas capacitações? Localização dos segmentos que são foco. Avaliação da empresa quanto ao número de segmentos existentes. Quais segmentos possibilitam renda e retorno crescentes? Estatísticas dos preços dos produtos? Características dos produtos comercializados pela empresa: tendem à padronização ou à diferenciação?

- Considerações sobre a sofisticação dos usuários. Importância da proximidade dos usuários principais (diferenças nos segmentos). Caso em que os produtos foram desenvolvidos para os usuários no país de origem e depois comercializados no exterior pelas empresas. Percepção do valor da atividade de TI pelos usuários domésticos.

- $\quad$ Papel do marketing e da construção das marcas na atividade de TI. No(s) segmento(s) em que atua.

- $\quad$ Quais empresas detêm a liderança tecnológica nos segmentos em que atua?

Informações sobre o crescimento da organização em relação aos principais concorrentes e em relação ao segmento em que atua e em relação ao mercado como um todo. Segmentos nos quais as relações próximas com clientes são necessárias. Pode-se falar em controle de padrões? 


\subsection{Organização e estratégia empresarial.}

- $\quad$ Estratégias funcionais resultantes da relação entre necessidades do mercado e evolução das competências empresariais. Estratégias funcionais com relação a produto, formas de produção e RH.

Estratégia de produto: evolução. Exemplos de alterações contínuas ou produtos totalmente novos.

Novas formas de organização para facilitar o desenvolvimento de produto. Como está organizada (equipes multidisciplinares)? Autonomia das equipes?

Tentar classificar o processo de desenvolvimento de produtos.

- Características do processo produtivo. Produção em cima do que o comprador pede x produção em cima da previsão do que o comprador deseja.

- Características da força de trabalho (multifuncionalidade)

Importância do trabalho de equipe.

Funcionários: capacidade analítica x de comunicação

Pode-se falar em estilo de gestão mais participativo?

- $\quad$ Base da competição (evidências, comentários, exemplos): (a) qualidade e consistência de q. (b) Respostas rápidas aos compradores. (c) Velocidade da inovação. (d) Excelência produtiva. Ações que a empresa tem adotado para evitar a competição predatória de preços.

- $\quad$ Escolhas que a empresa fez quanto a: Objetivos. Produtos e serviços oferecidos aos compradores. Mercados em que vai atuar. Design e configuração de políticas como a empresa vai competir nos mercados. Como falar nas formas de competir, vantagem comparativa versus vantagem competitiva na atividade de TI e na empresa. Escopo competitivo. Estrutura organizacional (hoje e como é a estrutura organizacional no tocante àqueles que vão entregar o próximo produto da empresa). Grau de descentralização (p/ adaptabilidade e reatividade).

Integração destas escolhas. Por que estas escolhas (decisões) são superiores as da concorrência? Como a empresa declara construir barreiras à entrada de concorrentes? Criadas pela empresa ou por outros participantes da cadeia?

- $\quad$ Formas de obtenção de vantagens competitivas utilizadas pela empresa: downsizing, envio da produção p locais com salários mais baixos, pressionar fornecedores, maior número de trabalhadores temporários.

- $\quad$ Compreensão da relação entre competitividade e estratégia.

- $\quad$ Ambições da empresa. Posições de liderança almejadas. Processo de gestão para isto.

Como a alocação de recursos é influenciada por estes aspectos.

- $\quad$ Nível de investimento nas pessoas.

- Potencialidade dos recursos humanos (potencial sobrando em relação à utilização?)

- Taxa de trabalhadores dedicados à P\&D, sobre o total de trabalhadores, taxa de RH

altamente qualificados, por exemplo, técnicos e Engenheiros sobre o total de trabalhadores).

- Possui estrutura de P\&D formal? Detalhes?

- Quantas áreas estão envolvidas na tarefa de desenvolvimento de produtos?

- Integram muitas atividades internamente?

- Tentar entender como os recursos e competências estão alinhados ao ambiente de

forma a se tornarem a base para sua vantagem competitiva. Construção de novas competências? Fortalecimento de competências? O que tem abandonado?

- $\quad$ Comportamentos que devem ser alterados para que diferentes resultados venham a emergir.

- $\quad$ Evidências de que a empresa tem renunciado a atividades que foi excelente no passado. Ativos que a empresa detém. Considerações quanto à flexibilidade, especificidade dos ativos envolvidos, diferenciação dos produtos e tamanho dos pedidos / projetos. 
- $\quad$ Importância e características dos processos de aprendizado na organização. Investigar a ocorrência de formas tácitas.

Em que atividades funcionais a empresa avalia que deve concentrar suas forças?

Há distinção entre estratégias baseadas em vantagens competitivas e estratégias baseadas em vantagens comparativas.

- $\quad$ Descobertas de possibilidades de troca até então desconhecidas.

- Avaliar o quanto de intento estratégico e qualidade da estratégia para antecipar as possibilidades de sucesso internacional.

- Eventuais alegações como falta de antiguidade e experiência, escassez de RH, financeiros e tangíveis de modo geral como obstáculos à internacionalização em larga escala. Visão global e conjunto de capacitações planejado a partir daí.

- Prontidão dos gestores para a gestão internacionalizada. Entender como funcionam no contexto global: a procura de oportunidades, o estabelecimento de canais de distribuição, questões como suporte e construção da marca.

- $\quad$ Como vê o diferencial da empresa em termos de capacitação em processos de produção e em processos de distribuição? E em habilidades estratégicas da alta administração ou rotinas organizacionais? Nível de capacitação tecnológica e organizacional (investimentos nisso). É possível afirmar que a empresa tem alguma capacitação inimitável?

- $\quad$ Avaliar se a empresa está usando as opções estratégicas:

- Diversificação de mercados. Inteligência de exportação, participação em feiras. Relutância na diversificação (com discrição? Outras empresas?).

- Uso eficaz do conhecimento adquirido dentro da cadeia. Como tem utilizado conhecimento adquirido em um mercado para operar em outro mercado?

- Exemplos de como a empresa tem dado foco aos sistemas de acumulação de conhecimento.

- Presença de elementos que alteram o conhecimento (gestão de processos de inovação, design e desenvolvimento de produtos ou busca de novos produtos e processos tecnológicos).

- $\quad$ Classificação do estágio em que a empresa se encontra.

Estágio I: é apenas procurada por importadores de outros países.

Estágio II: capacitação interna de design (desenvolvimento interno?) Precisa dos compradores para especificações.

Estágio III: Especialização em poucos produtos ou abriu o escopo e aumentou a linha?

Estágio IV: Passo sério. Alto investimento adicional, risco. Investimento em RH.

Competitividade em preço depende da habilidade de marketing e distribuição física.

Investimento nas próprias capacitações. Organizações maiores e mais sofisticadas nos

mercados externos. Valor unitário dos itens (altos?). Que vantagem competitiva tem? Escala, escopo ou aprendizado? Tem investido em novas vantagens competitivas?

Estágio V: Localizações em outros países.

- $\quad$ Estratégia básica quanto à competitividade. (a) Especialização em produtos massificados com grandes economias de escala? Especialização em produtos que necessitam de lotes enormes p atingir escalas mínimas de eficiência. (b) Foco em mercados de nicho. Inteligência de mercado e tecnológica. (c) Automatização de processos e terceirização. (d) Competição com base em novas tecnologias. JV, acordos de licenciamento de tecnologia, P\&D próprio (nível de investimento em relação a padrões internacionais). IDE (já pensou na possibilidade de transferência de atividades p o exterior?).

Competitividade da empresa? (no sentido de apresentar qualidade superior e custos mais baixos). Consegue identificar diferenças nos custos de produção? Em que etapa? Como é possível quantificar isto? Outras medidas (mesmo que não quantitativas).

- Importância da mão de obra de baixo custo.

- Grau de associação entre busca da competitividade e foco no preço. 
Evidências? (renda para os acionistas no longo prazo?). Participação no mercado de exportação? Dependência de exportações? Crescimento das exportações? Exemplos de sucesso nos mercados de exportação. Grau de compromisso com negócios internacionais? IDE? Quem são os concorrentes de outros países que competem nos mesmos segmentos de mercado? Em que bases estas empresas competem? Acredita (detalhes) que segmentos superiores, isto é mais sofisticados, oferecem renda mais alta? Onde se localizam concorrentes, fornecedores e compradores no mundo e como esta localização influencia a estratégia da empresa?

- $\quad$ Fase do CVP dos produtos da empresa (Introdutória, maduros). Nível de interação entre produtores e usuários.

- $\quad$ Abordagem da empresa quanto à qualidade. Make or buy (acertos e erros aqui) e relação com outras empresas.

- Estratégia da empresa quanto à terceirização de competências facilmente encontráveis no mercado e quasi hierarquia de competências complementares. Como a empresa tem realizado a gestão de competências da base interna e da base externa como resposta às novas pressões competitivas? Competências empresariais que tornam a empresa diferente das outras.

- V V Visão da empresa quanto a relações de competição e cooperação com outras empresas (concorrentes, clientes e fornecedores). Força das alianças.

- Cuidados com conseqüência da fragmentação das cadeias. Offshoring do design. Formação de empreendimentos conjuntos.

- $\quad$ Investigar estrutura interna para processar e utilizar informações e o conhecimento que se teve acesso nos mercados internacionais. Relação com o porte da empresa. Formas de obtenção destas informações.

- $\quad$ Treinamento em marketing e comércio internacional na empresa.

\subsection{Participação em cadeias e redes empresariais. Coordenação de atividades através de}

\section{fronteiras.}

- $\quad$ Inventário das redes e conexões relevantes com as quais se relaciona.

- $\quad$ Como a empresa coordena ou tem suas atividades coordenadas através de fronteiras? Relacionamento com empresas multinacionais. Acredita que a conexão às GVCs seja uma forma de entrar nos mercados globais?

\subsection{Aprendizado com empresas estrangeiras.}

- $\quad$ Exemplos de situações em que a empresa mostrou capacidade de aprender na atuação junto aos mercados globais.

Aprendizado com os compradores globais. Detalhar o que tem ocorrido com relação a: (a) Preço. (b) Confiabilidade na qualidade do produto. (c) Tempo de resposta da empresa. (d) Evidências de entrega pontual. (e) Flexibilidade (Aceitam pedidos pequenos? Aceitam alterações em pedidos grandes?) (f) Que evidências existem de que a empresa pratica design inovador?

- $\quad$ Intenção de aprender com estrangeiros. Evidências?

\subsection{Formas de atuação no exterior.}

- $\quad$ Exemplos de evolução sem dar importância às fronteiras nacionais.

- $\quad$ Fontes de vantagem competitiva nos negócios internacionais do setor de TI. Avaliação quanto à facilidade de replicação. 
- $\quad$ - Como entrou nos mercados estrangeiros? Exportações? Flexibilidade? Custos reduzidos? Confiança na capacitação dos facilitadores para lidar com a complexidade dos mercados externos? Criteriosa utilização dos distribuidores no exterior para resposta rápida, conhecimento das ações da concorrência e dinâmicas condições de mercado. Possibilita relacionamento diferenciado com os compradores em que termos?

- $\quad$ Abertura de filiais no exterior, relação com comercialização de ativos intangíveis como marca e know how. Evidências de que busca o sucesso nos mercados internacionais de forma pró-ativa (pensou na possibilidade de transferir atividades p o exterior?).

\subsection{Renda. Formas de criação e obtenção de novos fluxos de renda.}

- $\quad$ Avaliação da vantagem competitiva. Heterogeneidade dos recursos. Limites à competição. Mobilidade imperfeita.

- $\quad$ Evidências da capacidade empreendedora e de inovação (permanente?). Indicadores de inovação utilizados na empresa. Como estes indicadores se comparam com a concorrência?

Como estas inovações geraram mais renda para a operação?

- Aperfeiçoamento de competências com desmembramento externo (o aperf não ocorre somente dentro da empresa).

- $\quad$ Exemplos onde a estratégia competitiva foi bem sucedida por ser diferente. Pode citar um exemplo de estratégia de criação de valor que não tenha sido rapidamente implementada pelos concorrentes?

- No que a organização é diferente das demais atuantes no mercado?

- $\quad$ Como declara obter renda superior?

- $\quad$ Ações da empresa quanto a impedir que as forças competitivas que fazem as rendas superiores tenderem a zero atuem.

- $\quad$ Criação e proteção de novos fluxos de rendas.

- $\quad$ Renda relacional. Relacionamento superior com fornecedores e clientes? Por que forma de relacionamento escolhida minimiza o custo de transação?

- $\quad$ Assimetria informacional. O que a empresa sabe que os outros não sabem?

- $\quad$ Como as empresas, ou alguma empresa, têm influenciado estas mudanças de forma que o resultado favoreça a organização. Poder das empresas maior ou menor.

\subsection{Desempenho empresarial e ocorrência de aperfeiçoamento competitivo.}

- $\quad$ Quanto à produtividade, que indicações pode apresentar para se comparar aos principais concorrentes?

- $\quad$ Consegue identificar diferenças nos custos de produção? Em que etapa? Como é possível quantificar isto?

- Como a empresa pode afirmar que seus produtos, em suas características relacionadas e não relacionadas ao preço, formam um conjunto mais atraente que seus concorrentes.

- $\quad$ Especular sobre o AC de alto nível, através da inovação, novas tecnologias, desenvolvimento de produtos novos e/ou melhores e através da reação mais veloz às mudanças de mercado.

- $\quad$ Evidências de que a organização tem se adaptado, se reconfigurado e se transformado. Freqüência com que isto tem ocorrido.

- $\quad$ Exemplos onde houve aprendizado de clientes exigentes e usuários líderes em serviços de TI.

- Tentar entender o perfil da trajetória de aprendizado (grande nos anos iniciais, caindo depois??) Estabelecimento de relação com grau de concentração no segmento comprador. 
- $\quad$ Como se poderia classificar a capacidade de aprender da empresa. Equilíbrio entre dependência de rotinas e criatividade. Capacidade de renovação da empresa. Exemplos. - Origem do desempenho inovador da empresa? Estratégias? Histórico de inovação?

- Indicações sobre participação de mercado e rentabilidade.

- Investigar tecnologias utilizadas quanto à complexidade e proximidade da fronteira do conhecimento. Se a organização está próxima da fronteira e utiliza tecnologias que podem ser classificadas de mais complexas, como ocorreu esta evolução no aspecto organizacional.

- $\quad$ Evidências de que a empresa tem tornado seus atributos mais sofisticados (pensar não só em tecnologia, mas também em marketing, formas de comunicação, posicionamento do produto).

- $\quad$ Entender se a empresa tem funcionado como OEM, ODM ou OBM. O que tem sido aperfeiçoado? Processos? Produtos? A empresa tem mudado de função na cadeia?

- $\quad$ Indicações de que tem havido aperfeiçoamento competitivo ou marginalização competitiva? (tentativa de qualificar se a organização fordista ou pós-fordista).

- $\quad$ Investigação do aperfeiçoamento competitivo.

Aperfeiçoamento de processo $(\mathrm{P} \& \mathrm{D}$, alterações em logística, em práticas relacionadas à qualidade, novos equipamentos). Como saber? Custos mais baixos, melhora da qualidade e desempenho de netrega, tempo para chegar ao mercado diminuído, lucratividade aumentada, melhora na atividade relacionada a patentes. Capacitação dos parceiros para o ebusiness, aprendizado facilitado, evolução da lucratividade em toda a cadeia de valor.

Aperfeiçoamento de produto - movimentação para linhas de produto mais sofisticadas, expansão dos departamentos de marketing e design (desenvolvimento?), utilização de times funcionais (de vários deptos), grau de cooperação com fornecedores e clientes no desenvolvimento de novos produtos. Como saber? Participação de novos produtos nas vendas? Proporção de novos produtos no catálogo (?)?Participação de produtos com marcas próprias nas vendas, número de marcas registradas, aumento nos preços unitários dos produtos vendidos sem prejuízo de participação de mercado.

Aperfeiçoamento funcional - desempenho de nova funções na cadeia. Investigar eventual bloqueio de empresas líderes. Desempenho de novas funções que adicionam valor, específicas das cadeias, absorvidas de outros elos das cadeias, terceirização de atividades que adicionam pouco valor, movimentação para novos elos das cadeias e/ou abandono dos elos existentes. Como saber? Divisão do trabalho na cadeia? Funções-chave desenvolvidas nos elos individuais da cadeia? Aumento da lucratividade? Aumento da capacitação (como medir?) e do perfil salarial.

Aperfeiçoamento inter-setorial - aplicação das competências adquiridas em uma particular função da cadeia em um novo setor. Abandono da produção em uma cadeia e movimentação para outra, acréscimo de atividades em uma nova cadeia de valor, aumento da lucratividade, proporção de vendas de novas e diferentes áreas de produto.

Investigar se o aperfeiçoamento competitivo não está limitado à esfera da produção.

Evidências da progressão ou não para funções de marketing e design da cadeia.

1.54 - Existência de inibidores e impulsionadores do aperfeiçoamento competitivo

Inibidores

- Resistência dos níveis gerenciais.

- Compromisso de recursos para o desenvolvimento de novos produtos.

- Falta de capacitação (tentar ser + específico).

- Compradores que impedem que fornecedores desenvolvam design próprio.

- Direitos de propriedade intelectual.

- Infra-estrutura de TI deficiente na economia.

- Falta de capacitação no país.

Impulsionadores 
- Alta administração comprometida com o aperfeiçoamento competitivo.

- Gestão eficaz de P\&D

- Processos estruturados para o desenvolvimento permanente.

- Instituição que domina a cadeia promove apoio e assistência ao AC dos participantes.

- Provedores de serviços para as empresas, que estão estabelecidos e são pró-ativos, aliados a programas de governo facilitadores.

- Novas leis (quadro regulatório - institucional) que obriga as empresas a se aperfeiçoarem em termos competitivos.

- Aumento de preços dos insumos e/ou aumento da concorrência.

Aperfeiçoamento competitivo: indicações de que a empresa começa por segmentos menos sofisticados do mercado global. Possibilidade de atuar em um segmento mais sofisticado em seqüência a atuar em um menos sofisticado no mercado global. Detalhes de como isto pode acontecer ou está acontecendo.

\section{Caracterização da cadeia (ou rede) produtiva}

\subsection{Forma de surgimento da cadeia / rede. Cadeia rede local em comparação com a rede} / cadeia global. Sistema global e formas de interação.

- $\quad$ Caracterização do sistema global de produção de TI, se é que existe um (a exemplo dos setores automobilístico, de confecções etc.)

- $\quad$ Nível de interação entre produtores e usuários. É possível definir claramente uma GVC em TI?

- $\quad$ Poderia afirmar que a empresa brasileira de TI em alguma circunstância é um participante ativo do sistema global de produção de TI? Evidências?

- $\quad$ Especialização da cadeia. Histórico de como cresceu.

- $\quad$ Por que a cadeia do TI é ou não é complexa? Relacionar resposta com governança.

\subsection{Funções na cadeia.}

- Caracterização dos outros atores econômicos da rede (inovadores, designers, fornecedores de insumos, comerciantes, financistas, atacadistas e varejistas). Porte, grau de atualização tecnológica .... . Quem desempenha atividades complexas além do design, como por exemplo especificação de processos e sincronização de atividades? Ambiente institucional brasileiro. Definição dos parceiros nas cadeias, além da empresa líder. Principais fornecedores. Principais clientes. Concorrentes. Governo, indústria cultural, saúde, serviços não comercializáveis e educação. Se existe rede e parceiros, como cada um destes últimos contribui para a competitividade empresarial da rede?

- $\quad$ Redes de empresas em operação? Quais são e quem desempenha atividades complexas como design de produtos, especificação de processos e sincronização de atividades?

- $\quad$ Caracterização do papel desempenhado pelos intermediários.

\subsection{Governança e suas relações e efeitos na competitividade, no aperfeiçoamento} competitivo e na renda das empresas.

- $\quad$ Há empresas que determinam parâmetros operacionais e as outras empresas seguem? 
- $\quad$ Pode afirmar que algum perfil de organização ou organização impõe sua forma de organização econômica aos outros atores?

- $\quad$ Caracterização da forma de governança na cadeia.

- $\quad$ Existência de empresas líderes nas cadeias (como nos produtos eletro-eletrônicos) e fornecedores de pacotes prontos.

- $\quad$ Papel e características das empresas líderes das cadeias, se existem. Imposição de exigências?

- $\quad$ Caracterização do papel desempenhado pelos líderes das cadeias. Constrangem o aperfeiçoamento funcional? Estimulam? Indicações?

- $\quad$ Forma de obtenção do status de empresa líder: aprendizado, inovação, aperfeiçoamento tecnológico em formas complexas de conhecimento e conteúdo, melhor conhecimento dos aspectos da demanda propriedade intelectual e patentes, habilidade de transmissão de cultura operacional a fornecedores.

- $\quad$ Alguma empresa ou elo da cadeia controla uma tecnologia fundamental à atividade ou detém competência distintiva?

- $\quad$ Autoridade. Nível de integração vertical. Grupos. Conceitos de produção enxuta. Confiança. Transações repetitivas. Proximidade social. Economia de escala. Codificação.

- $\quad$ Percepção quanto às possíveis falhas da integração vertical.

- $\quad$ Se a cadeia é dominada pelos compradores, compradores determinam que produtos devem ser disponibilizados e quando isto deve ocorrer, bem como interpretação de tendências e especificação de processos?

- $\quad$ Monitoramento do desempenho e decisões específicas sobre quais produtores e exportadores serão incluídos ou excluídos da cadeia.

- $\quad$ Empresa líder (da cadeia) em termos de sua participação de mercado. Investigar se empresa líder (da cadeia) não detém a maior participação de mercado.

- $\quad$ Forma de ligação entre empresas contratualmente independentes? Forma de evolução desta ligação (hierarquia ou mercado)?

- Vantagens da hierarquia sobre a rede. Racionalidade limitada, oportunismo, incerteza, assimetria de informações.

- $\quad$ Fluxo de informações e fluxo de governança. Características da cadeia de TI que permitem afirmar que se trata de uma cadeia governada pelos compradores ou pelos produtores. Atividades dos que governam a cadeia.

- $\quad$ Compradores influenciam toda a estrutura da cadeia (número e o tipo de firmas envolvidas e a distribuição de funções entre elas)?

- $\quad$ Necessidade de especificação de parâmetros pelos compradores ao longo da cadeia.

- $\quad$ Dá para afirmar que o comprador é o elo dominante?

- $\quad$ Classificação da forma de governança da cadeia de valor.

- Legislativa: imposição de padrões para fornecedores em relação à pontualidade e qualidade.

- $\quad$ padrões ambientais e padrões relacionados ao trabalho infantil.

- Judicial: monitoramento do desempenho de fornecedores no cumprimento de padrões.

: monitoramento de padrões relacionados ao trabalho por ONGs. Empresas

especializadas que monitoram conformidade aos padrões ISO.

- Executiva: Gestão da cadeia produtiva, de forma a apoiar os fornecedores a cumprir os padrões. Associações que apóiam seus membros a cumprir padrões. Provedores de serviços especializados, suporte governamental em termos de política industrial.

- $\quad$ Indicações que a governança da cadeia está se tornando menos formal. Efeitos na governança.

- $\quad$ Comparação do que ocorre na cadeia global e na cadeia nacional do mesmo setor em termos de governança e tipo de aperfeiçoamento. Outras ligações locais. Como surgiu a 
cadeia global em comparação com a nacional? Explicações possíveis: intensidade do capital, custos de transação, e do trabalho.

- $\quad$ Percepção da importância da governança para o acesso ao mercado, rapidez para se capacitar.

- $\quad$ Se participa em mais do que uma cadeia, comparar as trajetórias (diferentes?).

- $\quad$ Grau de diferenciação de produtos versus governança. Arquitetura do produto: integral versus modular.

- $\quad$ Governança versus necessidade do comprador determinar com precisão as características do produto e risco do fornecedor não desempenhar a contento.

- $\quad$ Onde estão as grandes recompensas na cadeia de TI (funções mais rentáveis na GVC de TI)? Natureza dos papéis que propiciam estas grandes recompensas na cadeia? (evidências que a empresa tem se movimentado para estes nichos)

- $\quad$ Envolvimento direto da empresa líder na atividade de coordenação.

\subsection{Características da interação / cooperação / contratos.}

- $\quad$ Quanto à estrutura da cooperação entre as empresas, é possível falar em rede? Se existem redes e parceiros, como cada um destes últimos contribui para a competitividade empresarial da rede?

- $\quad$ Características dos contratos entre as empresas (incompletude?)

- $\quad$ Características desejáveis dos recursos e capacitações na rede para geração de renda superior. Complementaridade (?). Escassez. Baixa possibilidade de comercialização. Bx possib de imitação. Bx possibilidade de substituição. Apropriabilidade. Durabilidade. Convergência com fatores estratégicos do setor.

- $\quad$ Detalhes sobre as características da rede na qual a organização está conectada.

- $\quad$ Evidências de que a interação na cadeia do TI é organizada (em contrapartida a ser aleatória).

- $\quad$ Como são as ligações entre estes atores e como variam em função das características do produto? Quais atores podem ser classificados como empresa integrada, empresa líder, fornecedor turn key, fornecedor de componentes?

- $\quad$ Oportunismo na cadeia.

- $\quad$ No relacionamento com outras empresas fora, ocorre de empresas ficarem travadas na posição? Especialização em uma atividade em especial? De produção? Número de compradores? Capacitação em marketing (gestão de marcas, por ex.)? Dependência do relacionamento? Compradores demandam exclusividade? Novas formas de competição nesses relacionamentos?

- $\quad$ Como classifica as relações na cadeia de TI? São de mercado ou não? (se uma empresa tem algum nível de influência sobre a ação das outras, então já não pode ser considerada de mercado).

- $\quad$ Investigar e procurar evidências do nível de confiança entre as empresas da cadeia, estabilidade e desenvolvimento do conhecimento.

- $\quad$ Dificuldade de iniciar e terminar relacionamento com fornecedores. Resistência às ligações com atores fora da rede (redes exclusivas). Rede relacional. Vantagem da flexibilidade e desvantagens das altas barreiras à entrada, da imobilidade geográfica e da inexistência de economias de escala em caso de estrutura fragmentada. Custos de coordenação e isolamento em relação aos compradores.

- $\quad$ Características da rede virtual dos EUA. Agilidade produtiva e geográfica.

- $\quad$ Estabilidade da forma de organização econômica? Percepção sobre a fragilidade da rede. 
- $\quad$ Existência de vários níveis de fornecedores?

- $\quad$ Como são as ligações locais que a empresa tem?

- $\quad$ Características de fragmentação da rede em relação ao que se tem na Ásia (Coréia, Japão, Taiwan, HK e Cingapura). Comparação com o que é bem sucedido e com o que não é bem sucedido.

\subsection{Cadeia / rede e entrada das empresas nos mercados dos países desenvolvidos.}

- $\quad$ Existem funções que têm sido transferidas para as empresas de países em desenvolvimento? Quais? Elaborar sobre o tema.

- $\quad$ Dependência (influência) da entrada na rede de produção para acesso aos mercados dos países desenvolvidos. Evidências?

- $\quad$ Caracterização da importância das empresas transnacionais de TI na cadeia de valor?

- $\quad$ Papel desempenhado pelas empresas brasileiras nas GVCs. Comparar este papel com o papel desempenhado pelas empresas dos países desenvolvidos. Concentração da inovação nas empresas dos países desenvolvidos.

- $\quad$ Características das relações com as empresas dos países desenvolvidos (são relações do tipo rede?).

- $\quad$ Quando se caracteriza a cadeia de TI, pode-se falar em cadeia orientada para a exportação?

- $\quad$ Forma pela qual os compradores externos nutrem o sucesso exportador:

- Fornecimento de informações.

- Apoio à Enga de Produto e Processo

- Provimento de acesso à rede de distribuição.

- Apoio ao desenvolvimento de ligações para as empresas nos mercados domésticos e externos.

\subsection{Cadeias / redes concorrentes}

- $\quad$ Identificação de redes similares que têm como foco os mesmos mercados no exterior.

\subsection{Recursos e capacitação da cadeia / rede}

- $\quad$ Diferencial de competência entre compradores e vendedores.

- $\quad$ Características da rede que permitam classificar mais como rede de produção ou mais como rede de conhecimento. 


\section{APÊNDICE 2 - INFORMAÇÕES ENVIADAS AOS ENTREVISTADOS PREVIAMENTE ÀS REUNIÕES.}

\section{O SETOR, A EMPRESA E A REDE / CADEIA PRODUTIVA}

\section{O setor e a empresa}

1.1 Ambiente e mercado.

1.2 Segmento foco da atuação.

1.3 Organização e estratégia empresarial.

1.4 Participação em cadeias e redes empresariais. Coordenação de atividades através de fronteiras.

1.5 Aprendizado com empresas estrangeiras.

1.6 Formas de atuação no exterior.

1.7 Renda. Formas de criação e obtenção de novos fluxos de renda.

1.8 Desempenho empresarial e ocorrência de aperfeiçoamento competitivo.

\section{Cadeia (ou rede) produtiva}

2.1 Forma de surgimento da cadeia / rede. Cadeia rede local em comparação com a rede / cadeia global. Sistema global e formas de interação.

\subsection{Funções na cadeia.}

2.3 Governança e suas relações e efeitos na competitividade, no aperfeiçoamento competitivo e na renda das empresas.

2.4 Características da interação / cooperação / contratos.

2.5 Cadeia / rede e entrada das empresas nos mercados dos países desenvolvidos.

2.6 Cadeias / redes concorrentes.

2.7 Recursos e capacitação da cadeia / rede. 


\section{APÊNDICE 3 - CARTA ENVIADA COM SOLICITAÇÃO DE REUNIÃO}

São Paulo, 13 de dezembro de 2007.

A

EMPRESA DE TI

At: DR. FULANO DE TAL

Avenida Tal, $\mathrm{n}^{\circ} 00$

Cidade, Estado, Brasil

00000-000

Assunto: Inserção internacional de empresas de Tecnologia da Informação (TI)

Prezados senhores,

O contato visa obter sua colaboração para o estudo intitulado "Estratégia Empresarial, Governança e Renda em Cadeias Globais de Valor: Casos em Tecnologia da Informação”.

Visto que detectamos que sua empresa tem destacada atuação no segmento de mercado de interesse deste estudo, gostaríamos de realizar uma entrevista pessoal em data e horário da sua conveniência. Convém assinalar que as informações compartilhadas conosco serão tratadas de forma despersonalizada a fim de preservar o anonimato dos entrevistados e respectivas organizações.

Seu apoio é fundamental para que possamos entender com mais detalhes o tema investigado, relacionado à inserção internacional de empresas de TI através de cadeias globais de valor.

Estabeleceremos contato telefônico para tratar do acima exposto e agradecemos desde já sua cooperação.

Atenciosamente,

PROF. EDUARDO ARMANDO

DOUTORANDO EM ADMINISTRAÇÃO FEA / USP

Fones: (11) 0000-0000; (11) 0000-0000

Fax: (11) 0000-0000

e-mail: earmando@usp.br
PROF. DR. ADALBERTO A.

\section{FISCHMANN}

PROFESSOR TITULAR

FEA / USP

Fone: (11) 0000-0000

e-mail:aafischm@usp.br 